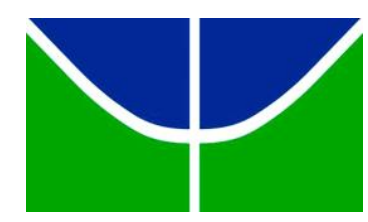

UNIVERSIDADE DE BRASÍLIA INSTITUTO DE CIÊNCIAS SOCIAIS

DEPARTAMENTO DE ANTROPOLOGIA

PROGRAMA DE PÓS-GRADUAÇÃO EM ANTROPOLOGIA SOCIAL

\title{
UNISUS \\ Do Projeto Político à Política do Processo
}

Igor D’Ávila Baseggio 
UNIVERSIDADE DE BRASÍLIA

INSTITUTO DE CIENNCIAS SOCIAIS

DEPARTAMENTO DE ANTROPOLOGIA

PROGRAMA DE PÓS-GRADUAÇÃO EM ANTROPOLOGIA SOCIAL

\section{UNISUS \\ Do Projeto Político à Política do Processo}

Igor D’Ávila Baseggio

Dissertação submetida ao Programa de Pós-Graduação em Antropologia Social da Universidade de Brasília como um dos requisitos para a obtenção do título de Mestre em Antropologia Social.

Orientadora:

Prof $^{a}$ Carla Costa Teixeira 
UNISUS: Do Projeto Político à Política do Processo

\title{
Dissertação submetida ao Programa de Pós-Graduação em Antropologia Social da Universidade de Brasília como um dos requisitos para a obtenção do título de Mestre em Antropologia Social.
}

Aprovada por:

\author{
Prof. . . Carla Costa Teixeira (DAN-UnB) \\ Presidente
}

Prof. a . Soraya Resende Fleischer (DAN-UnB)

Examinadora Interna

\section{Prof. a . Ximena Pamela Claudia Díaz Bermúdez (FSC-UnB) Examinadora Externa}

Prof. Luis Abraham Cayón Durán (DAN-UnB)
Suplente

Brasília

Novembro, 2014. 


\section{AGRADECIMENTOS}

Aos professores e professoras do Departamento de Antropologia da Universidade de Brasília Andréa Lobo, Antonádia Borges, Carlos Sautchuck, Christine Chaves, Daniel Simião, Danielli Jatobá, Gustavo Ribeiro, Juliana Dias, Kelly Silva, Luis Durán, Marcela de Souza, Soraya Fleischer e Wilson Trajano F. pelo trabalho prolífico e dedicação úbere nos caminhos e desafios dessa jornada única que me formou nos assuntos da Antropologia desde 2006. Agradeço também à Cristiane Romão, Jorge Máximo, Paulo Souza e Rosa Cordeiro pela solicitude sempre generosa em muitos momentos.

À Carla Teixeira, minha professora e aqui orientadora, por ter me guiado e orientado nas trilhas reflexivas e argumentativas da dissertação propiciando firmeza, liberdade e tempo, primordiais durante todo o processo e de pesquisa e escrita.

Ao Conselho Nacional de Desenvolvimento Científico e Tecnológico (CNPq) pela provisão do suporte e bolsa de estudos para o curso e pesquisa.

Ao Fernando Natal e Ubirajara Picanço, sujeitos cruciais para a pesquisa, pela abertura das primeiras portas, essenciais ao processo todo. Sem eles não haveria pesquisa.

À todas as pessoas da Escola Superior de Ciências da Saúde e da Fundação de Ensino e Pesquisa em Ciências da Saúde que contribuíram e participaram durante a pesquisa. Dedico a cada um deles e delas as páginas que se seguem.

Aos meus pais, Ricardo e Nara, aos quais devo a vida duas vezes a cada um.

À minha irmã, Rafaella, que sempre foi exemplo de força, sabedoria, energia e vida.

À Aracy Roza, Ítalo Batista e Narla Skeff. Palavras não expressam minha gratidão.

À Adriana Batista, Alexandre Fernandes, Amanda Frenkle, Ana Cândida, Ana Lívia, Ana Paula, Ana Rabêlo, André Macedo, Bernardo Leal, Bruna Penha, Bruna Seixas, Bruner Nunes, Bruno Carvalho, Carlos Oviedo, Carolina Moreno, Cassiane Campos, Clarisse Jabur, Danilo Oliveira, Denise Forini, Diego Barrios, Eduardo Di Deus, Eduardo Nunes, Ester Oliveira, Felipe Cardoso, Francisco Vieira, Gabriela Caniello, Gabriela Landim, Graciela Froehlich, Gregório Benevides, Guilherme Moura, Gutcha Magalhães, Herika Chagas, Igor Karim, Igor Perfeito, Izis Morais, Janeth Bravo, João Jatoba, Julia Arcanjo, Julia Pantoja, Julia Sakamoto, Kamila Figueira, Kílvia Cunha, Layla Cesar, Lediane Felzke, Lena Tosta, Leonardo Ferreira, Lucas Farage, Lucas Marques, Lucas Rocha, Luciano Vilela, Luiza Oliveira, Marcela Alvim, Marco Martínez, Maria Cintra, Maria Romero, Mariana Castro, Mariana Garcia, Mariana Lima, Martiniano Neto, Maurício Médici, Millena Saturnino, Natália Maria, Natália Silveira, Nicholas Castro, Paique Santarém, Paloma Maroni, Paola Huertas, Pedro Contesini, Rachel Otoni, Rafael Moreira, Rafael Rodrigues, Raissa Oliveira, Ramon Barroncas, Raoni Giraldin, Raquel Kojoroski, Raysa Martins, Rebecca Martins, Regina Bellanti, Roberto Mendes, Roberto Miyamoto, Roberto Reis, Rosana Castro, Samira Dias, Tadeu Bernardes, Taíssa Tokarski, Talita Neves, Tayenne Cabral, Thais Brayner, Thais Corsete, Tiago Victorio, Túlio Reis, Veronica Lucena, Vitor Camargo, Welliton Maciel, Yoko Souza, por toda e cada conversa e ideia, das maiores às menores, por toda e cada experiência, dos mais breves aos mais duradouros encontros de cada um de nossos caminhos nessa fase de nossas vidas.

À Bernadete Grande, Ermaine Barbosa e Ingrid Maciel, professoras dos velhos tempos, por terem sido inspiração e exemplos de maestria que permanecem até hoje.

Ao Marcelo Araújo pelo tempo, espaço, incentivo, humanidade e mais. 
O passado está contido no presente como este no futuro.

E. E. Evans-Pritchard

$(1951,63)$ 


\title{
RESUMO
}

Esta dissertação é resultado de trabalho etnográfico realizado em torno de um processo de transformação institucional na Escola Superior de Ciências da Saúde, ESCS, que seria transformada na chamada Universidade de Ciências da Saúde do Distrito Federal, UNISUS, a primeira universidade distrital especializada em ciências da saúde em Brasília. Com metodologia pedagógica diferente dos modelos disciplinares de ensino em medicina e com a realização de atividades pedagógicas nas unidades assistenciais do próprio sistema público de saúde local, a instituição parecia desafiar os modelos de gestão dos processos pedagógicos e de gestão política do ensino em saúde no contexto do Estado. Mapeou-se a arena política local na qual interagiram os atores institucionais envolvidos com o processo abordado e destacou-se conflitos e controvérsias em torno do Projeto UNISUS no contexto da participação social e no controle social da saúde pública no Distrito Federal. Ao longo da dissertação, explora-se as profundidades históricas, institucionais, pedagógicas e políticas atuantes no processo abordado, refletindo-se analiticamente sobre os mecanismos da democracia participativa na gestão da saúde pública, sobre a implementação de modelos diferentes de gestão pedagógica e administrativa e sobre a gestão ideológica dos processos institucionais, e atreladas à um processo institucional que se mostrou como expressão da transformação do ensino em medicina em um contexto mais amplo.

Palavras-chave: formação médica, política pública, Estado, instituição, democracia.

\begin{abstract}
This dissertation results from an ethnographic fieldwork made around a process of institutional transformation at the Superior Health Sciences School, ESCS, which would be transformed in the University of Health Sciences of Distrito Federal, UNISUS, the first district university specialized in health sciences in Brasilia. Having a pedagogical approach different from the usual disciplinary models of medical training, and holding educational activities in the facilities of the local public health system, this institution seemed to challenge the pedagogical models and the political management of medical training in the context of the State. The local political arena was mapped. Therein, the institutional actors involved with the analyzed process interact, arousing controversies around UNISUS Project in the context of democratic representativeness and social control of public health in Distrito Federal. Throughout the study, historical, institutional, pedagogical and political depths are explored while it encourages a reflection on the mechanisms of democratic participation in public health management; on the ideological management; and on the implementation of different models of pedagogical management process, related to an institutional process which was an expression of the transformation of medical teaching in a broader context.
\end{abstract}

Keywords: medical training, public policy, State, institution, democracy. 


\section{LISTA DE FOTOS}

Foto 1 Placa com a missão institucional da FEPECS. 54

Foto 2 Placa com a Portaria $N^{\circ}$ 6, de 2 de agosto de 2000.

$\begin{array}{lll}\text { Foto } 3 \text { Placa com a celebração de convênios de cooperação interinstitucionais. } & 73\end{array}$

Foto 4 Objetos de divulgação: camiseta, adesivo e bóton da UNISUS. 142

\section{LISTA DE FIGURAS}

Figura 1 Cronograma de implantação da FEPECS e do curso de medicina.

Figura 2 Fluxo curricular do curso de graduação em medicina da ESCS.

Figura 3 Rede interinstitucional local.

\section{LISTA DE GRÁFICOS}

Gráfico 1 Quantidade de egressos do curso de medicina da ESCS versus total destes que foram admitidos pela SES-DF por turma.

Gráfico 2 Total geral de médicos admitidos pela SES-DF por ano versus total 128 destes que são egressos da ESCS.

\section{ANEXO E APÊNDICE}

Anexo

Ficha A de Cadastro da Família. Programa Família Saudável, GDF.

Apêndice Distribuição das admissões feitas pela SES-DF de egressos da ESCS. 


\section{LISTA DE ABREVIAÇÕES}

\begin{tabular}{|c|c|}
\hline ABEM & Associação Brasileira de Ensino Médico \\
\hline $\mathrm{ABP}$ & Aprendizagem Baseada em Problemas \\
\hline CAMIB & Centro Acadêmico Mourad Ibrahim Belaciano \\
\hline CEDF & Conselho de Educação do Distrito Federal \\
\hline CEDRHUS & Centro de Desenvolvimento de Recursos Humanos para a Saúde \\
\hline CFM & Conselho Federal de Medicina \\
\hline CINAEM & Comissão Interinstitucional Nacional de Avaliação das Escolas Médicas \\
\hline CLDF & Câmara Legislativa do Distrito Federal \\
\hline CODEP & Coordenação de Desenvolvimento de Pessoas \\
\hline CRM & Conselho Regional de Medicina \\
\hline CSDF & Conselho de Saúde do Distrito Federal \\
\hline DNSP & Departamento Nacional de Saúde Pública \\
\hline EAEB & Escola de Auxiliares de Enfermagem de Brasília \\
\hline EAPSUS & Escola de Aperfeiçoamento do Sistema Único de Saúde \\
\hline ENADE & Exame Nacional de Desempenho de Estudantes \\
\hline ESCS & Escola Superior de Ciências da Saúde \\
\hline ETESB & Escola Técnica de Saúde de Brasília \\
\hline FAMEMA & Faculdade de Medicina de Marília \\
\hline FEPECS & Fundação de Ensino e Pesquisa em Ciências da Saúde \\
\hline FHDF & Fundação Hospitalar do Distrito Federal \\
\hline GDF & Governo do Distrito Federal \\
\hline HA & Habilidades e Atitudes \\
\hline IDA & Programa Integração Docente-Assistencial \\
\hline IESC & Interação Ensino-Serviço-Comunidade \\
\hline MESP & Ministério da Educação e Saúde Pública \\
\hline MS & Ministério da Saúde \\
\hline PET-SAÚDE & Programa de Educação pelo Trabalho para a Saúde \\
\hline PRO-MED & Programa Nacional de Incentivo a Mudanças Curriculares de Medicina \\
\hline PRO-SAÚDE & Programa Nacional de Reorientação da Formação Profissional em Saúde \\
\hline SEC-DF & Secretaria de Educação e Cultura do Distrito Federal \\
\hline SE-DF & Secretaria de Educação do Distrito Federal \\
\hline SES-DF & Secretaria de Estado e Saúde do Distrito Federal \\
\hline SUS & Sistema Único de Saúde \\
\hline UEL & Universidade Estadual de Londrina \\
\hline UFRR & Universidade Federal de Roraima \\
\hline UNB & Universidade de Brasília \\
\hline UNI & Uma Nova Iniciativa \\
\hline UNICEUB & Centro Universitário de Brasília \\
\hline UNISUS & Universidade de Ciências da Saúde do Distrito Federal \\
\hline
\end{tabular}




\section{SUMÁRIO}

Introdução....................................................................................................................................... 10

Capítulo 1 - Da Gênese Política à Política da Criação.................................................. 17

O Estado e seus Ideais.................................................................................. 27

Da Virada Democrática ao Sistema Único de Saúde............................................ 40

Capítulo 2 - A “Distrital de Medicina de Brasília" ................................................ 50

Do Arquivo Institucional à Narrativa Monumental.......................................... 53

Criação da FEPECS e da ESCS.............................................................. 60

Convênios Institucionais................................................................... 70

Pedagogia dos Problemas......................................................................... 76

Inovadora Interação Ensino-Serviço-Comunidade.................................... 81

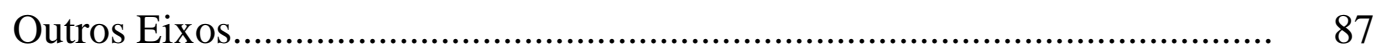

Problemas da Pedagogia........................................................................ 91

Capítulo 3 - Do Projeto à Política do Processo............................................................ 103

Etnografia de um Processo Institucional..................................................... 110

O Processo UNISUS................................................................................ 111

"É projeto politiqueiro" .................................................................... 112

“Os caminhos estão abertos" ................................................................. 133

“O que está acontecendo aqui é democracia" ......................................... 145

Considerações Finais...................................................................................................... 169

Referências Bibliográficas............................................................................ 181

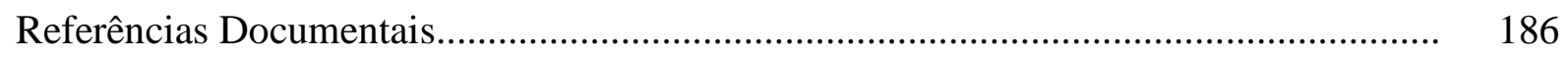

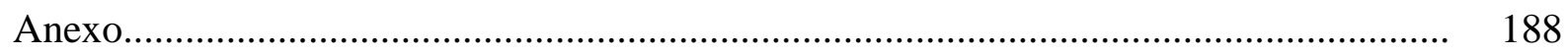

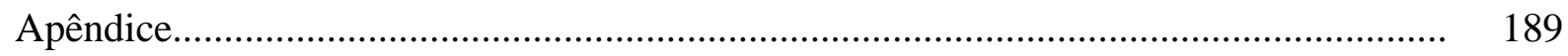




\section{INTRODUÇÃO}

Antes de apresentar o conteúdo desta dissertação em si, devo explicar como surgiu meu interesse pela Antropologia da Saúde e em abordar a temática da formação médica. Durante o curso de graduação em Antropologia Social na Universidade de Brasília, concluído em 2011, voltei minhas escolhas curriculares para disciplinas que trabalhassem as temáticas da "saúde" e do "corpo" e com o passar do tempo comecei a me interessar pelo tema da "formação médica" e "formação de terapeutas" pelas discussões e reflexões sobre diferentes concepções de saúde, doença e tratamento que as leituras acadêmicas permitiram fazer.

Meu trabalho de conclusão de curso na graduação, intitulado "Da Formação de Terapeutas: Etnografia da Prática e do Sentir em uma Escola de Acupuntura", foi o primeiro grande passo rumo aos estudos na área da Antropologia da Saúde. Ainda que eu o considere reflexivamente ingênuo, a feitura desse trabalho fez com que eu compreendesse melhor minha própria curiosidade em estudar os processos formativos de jovens terapeutas, assim como despertou meu interesse em compreender os sentidos das dinâmicas culturais e sociais inerentes ao exercício de determinadas práticas terapêuticas. No trabalho de conclusão de curso da graduação, parti de uma discussão sobre a aprendizagem daquilo que chamei de "sensibilidades terapêuticas", e o trabalho etnográfico foi realizado em uma escola de acupuntura. O objetivo inicial foi esboçar um estudo comparativo entre processos formativos e técnicos em um curso de acupuntura e em um curso de medicina e estabelecer paralelos entre dois cursos de formação em saúde. Essa seria uma tarefa bastante desafiadora e exigiria, necessariamente, dois trabalhos de campo em dois lugares diferentes. Entretanto, o empreendimento comparativo teve que ser deixado de lado quando me deparei com a dimensão do esforço etnográfico e reflexivo em abordar dois cursos completamente diferentes entre si para abordar temas tão subjetivos quanto "sensibilidades" e aprendizagens de técnicas terapêuticas tão distintas entre si.

Persistindo ainda com os planos comparativos, meu objetivo no mestrado, também em Antropologia Social, foi dar continuidade à reflexão no trabalho final de graduação, mas agora num curso de medicina para enfim dar início à uma aproximação comparativa entres dois universos formativos distintos. O objetivo inicial da pesquisa no mestrado foi estudar os processos de aprendizagem prática através do manejo de instrumentos e realização de 
procedimentos técnicos manuais, e também abordar a questão das "sensibilidades" e modos de abordagem terapêutica em contextos de formação.

Tive a opção de fazer o trabalho de campo no curso de graduação em medicina da própria Universidade de Brasília (UNB) ou na Escola Superior de Ciências da Saúde (ESCS), ambas instituições localizadas na cidade de Brasília, Distrito Federal. Optei por realizar a pesquisa de campo nesta última e as razões dessa escolha foram diversificadas. Primeiro, eu acreditava que fazer um trabalho etnográfico dentro de minha própria universidade não geraria distanciamento de minha própria realidade diária e o esforço em tornar o familiar em estranho seria maior do que se eu realizasse a pesquisa de campo em outra instituição, cujos locais e pessoas eu desconhecia. Segundo, uma informação que eu sabia sobre a Escola Superior de Ciências da Saúde (ESCS) era que ela adotava uma metodologia pedagógica diferente dos outros cursos de medicina, a qual se chama Aprendizagem Baseada em Problemas (ABP), que eu até então desconhecia, assim, poderia saber e conhecer outro modelo pedagógico de formação em saúde. Terceiro, eu também soube, através de colegas, que os estudantes nessa escola realizavam as suas atividades pedagógicas na própria rede pública de assistência de saúde do Distrito Federal desde o início do curso, fator que me despertou ainda mais a curiosidade quanto aos processos de aprendizagem nesse contexto. Quarto, com ajuda inicial de minha orientadora, pude contatar um dos professores que futuramente seria contratado para trabalhar na Escola Superior de Ciências da Saúde (ESCS) para que, assim, eu desse início à rede de interlocutores na pesquisa etnográfica. A partir desse professor, fui sendo inserido aos poucos na realidade da ESCS, fazendo contato com outros professores, funcionários e muitos estudantes, os quais atuaram como meus interlocutores na pesquisa ao longo de 2013 e início de 2014.

Durante a pesquisa de campo, os planos iniciais de estudar os processos de aprendizagem técnica e as "sensibilidades" terapêuticas minguaram na medida que fui surpreendido por um processo institucional em andamento na Escola Superior de Ciências da Saúde (ESCS) que parecia interessar e ao mesmo tempo preocupar os sujeitos envolvidos. A ESCS estava em vias de ser transformada em universidade, isto é, a futura Universidade de Ciências da Saúde do Distrito Federal, UNISUS.

O assunto da mudança parecia ser polêmico. A questão tomava parte nas discussões entre todos na Escola e suscitava uma série de valores e discussões que me chamaram atenção. 
Isto visto, deixei os objetivos iniciais quanto à abordagem das "sensibilidades" de lado e passei a fazer uma etnografia do processo de transformação institucional que estava acontecendo na Escola Superior de Ciências da Saúde (ESCS) em torno do chamado "Projeto UNISUS". Importante ressaltar que, apesar de a pesquisa ter se afastado dos objetivos iniciais, ela ainda permaneceu findada na temática da formação médica e, no entanto, passou a receber abordagem diferenciada, se afastando de uma antropologia das técnicas e foi em direção à antropologia das instituições, da política, da administração pública e, em certa medida, à uma antropologia do Estado.

No primeiro capítulo, apresento a questão da renovação do ensino médico conforme o ponto de vista de diversos atores políticos, institucionais e sociais quanto a consolidação de projetos públicos que visam a formação de recursos humanos para a saúde pública no Brasil a partir de modelos pedagógicos diferenciados. Na Escola Superior de Ciências da Saúde (ESCS), o valor da renovação do ensino vem atrelado à proposta de integração entre o ensino da medicina e dos serviços de saúde local através de modelos pedagógicos e de gestão política que é desafiador dos modelos tradicionais de pedagogia médica e de administração da saúde pública. Discuto sobre como esse movimento de transformação do ensino em medicina não é livre de tensões e disputas dentro das arenas políticas do Estado no Brasil. Em seguida, defino o conceito de Estado levado adiante na narrativa a partir das perspectivas teóricas de Benedict Anderson (1982) e Philip Abrams (1988), cujas perspectivas teóricas definem o "Estado" como uma rede que além de ser administrativa, é moralmente agregadora de valores ideológicos a partir do qual a vida política acontece e que oferece base moral sobre a qual determinados sensos de comunidade e pertencimento se fundam e abrem espaço para a existência de projetos públicos amplos no âmbito de uma "nação". Além desses autores, Michel Foucault (1979), Norbert Elias (1939, 1970) e Abram de Swaan (1988) tem suas perspectivas teóricas citadas com a finalidade argumentar que o avanço do controle do Estado nos meandros da administração da vida política de uma nação implicam na configuração e organização de relações de poder inescapáveis e que ordenam determinados entrelaçamentos coletivos inerentes ao desenvolvimento das estruturas de gestão e controle da vida pública.

Ainda no primeiro capítulo, faço um apanhado da forma com que a noção de Estado moderno avançou no controle das políticas de saúde voltadas para as atividades médicas e realizo a transição de uma abordagem geral acerca do surgimento do Estado nacional no 
contexto europeu, principalmente com a perspectiva teórica de Michel Foucault (1963, 1979), para uma abordagem de como se deu o avanço do controle do Estado sobre as questões do exercício da medicina no Brasil a partir do século XX até a virada democrática, a qual foi marcada pela promulgação da Constituição Federal de 1988, a qual marcou um ponto fulcral para o desenvolvimento das políticas de saúde no Brasil e do Sistema Único de Saúde (SUS), filho dileto da ideia de nação brasileira, assim como abriu espaço para o firmamento das noções de "democracia", participação social" e "cidadania" que perduram até os dias atuais.

Cito Machado et. al. (1988), Herchmann, Kropf, Nunes (1996) e Lima, Hochman (2000) para falar como se deu o avanço do Estado brasileiro sobre as questões da gestão das políticas de saúde pública nacional na mesma medida em que aponto o valor de "progresso" enquanto ferramenta ideológica que regia as políticas do Estado brasileiro no início do século XX. Traço, a partir daí, uma digressão histórica a partir de artigos de Pereira e Almeida (2005) e Guerreiro e Branco (2011) para mostrar a transição política marcada pela ditadura e o modo com que o valor de "progresso" foi atualizado pelos valores da "democracia", "inclusão" e "participação social" a partir da segunda metade dos anos 1980 no Brasil. Por fim, faço também uma digressão acerca dos principais programas e políticas públicas voltadas para o aprimoramento da gestão do ensino da medicina no Brasil a partir dos artigos de Borba e Neto (2008); Dias, Lima e Teixeira (2013); Garbi Novaes et. al. (2009), González e Almeida (2005); Hora et. al. (2013); e Siqueira-Batista e Siqueira-Batista (2009) e estabeleço conexões entre o desenvolvimento e aprimoramento das políticas públicas nacionais voltadas ao ensino em saúde ao contexto de renovação do ensino médico no Brasil nos últimos anos.

No segundo capítulo, parto da perspectiva histórica seguida desde o primeiro capítulo para falar dos precedentes e da trajetória em si da criação e inauguração da Escola Superior de Ciências da Saúde (ESCS) no Distrito Federal. A primeira porção desse capítulo é basicamente baseada no que pode-se chamar de uma "etnografia de documentos institucionais", cujos conteúdos evocam a maneira com que a própria instituição se posiciona no contexto de sua fundação e esboça os valores que a legitimam enquanto instituição não apenas pedagógica, mas também política, administrativa e ideológica. Apoio-me na perspectiva de Celso Castro (2008) para argumentar a favor das possibilidades analíticas que existem em pesquisas com documentos. Utilizo ainda a perspectiva de Mary Douglas (1986) com o objetivo de abordar a monumentalidade histórica esboçada nos documentos institucionais e de que forma isso implica 
nas relações cotidianas da vida política e ideológica da instituição na qual realizei a pesquisa de campo Nesse capítulo também descrevo com detalhes os passos para a criação da Escola Superior de Ciências da Saúde (ESCS), desde a construção do próprio sistema de assistência em saúde local, passando pelas discussões do grupo de trabalho responsável pela criação da ESCS no Distrito Federal e convênios institucionais que possibilitaram sua inauguração em 2001, indo ao encontro da importância dada à metodologia pedagógica adotada.

Na segunda porção do capítulo 2 discuto detidamente a metodologia pedagógica adotada pela ESCS, cuja principal é a Aprendizagem Baseada em Problemas (ABP). Faço uma breve análise bibliográfica de tal metodologia me apoiando nos textos de Gonçalves (2002); Siqueira-Batista (2009); e Batista e Gonçalves (2002). Nessa sessão descrevo cada componente curricular de forma detalhada, dando ênfase ao módulo temático de Interação Ensino-ServiçoComunidade (IESC), o qual traz consigo com maior preocupação a ideia de "inovação" e “integração" entre o ensino da medicina com os serviços locais de assistência em saúde, além de ser o módulo curricular que almeja, de maneira mais explícita, a familiarização dos estudantes com as políticas de "atenção básica", mote das políticas públicas de saúde no Brasil nos últimos quinze anos pelo menos. No final do capítulo teço algumas críticas aos possíveis dilemas que pude encontrar nas atividades pedagógicas e aponto os limites de tal metodologia pedagógica. Também busco apontar alguns limites na construção do perfil profissional do "médico total", termo usado pelos meus interlocutores para qualificar o sujeito profissional treinado para abordar os processos de doença-tratamento-saúde segundo a ótica da abordagem e integração "bio-psico-social”.

No terceiro e último capítulo descrevo com detalhes etnográficos o processo político e institucional que tratou da discussão do projeto de lei que visava a transformação da Escola Superior de Ciências da Saúde (ESCS) em Universidade de Ciências da Saúde do Distrito Federal (UNISUS). Inicio o capítulo descrevendo a configuração da rede de atores sociais e institucionais envolvidos nos embates nas arenas de discussão do Projeto UNISUS e, em seguida, traço algumas digressões sobre questões relativas ao controle social na saúde com base nas perspectivas teóricas de Sposati e Lobo et. al. (2010); Shimizu et. al. (2013) e Teixeira e Simas (2013), apontando o papel dos Conselhos de Saúde na implementação de debate e representatividade civis nas políticas públicas de saúde e o papel dessas instâncias na vida democrática dos projetos de políticas públicas de saúde do Estado. Na porção central do 
capítulo, a mais longa sessão da dissertação, descrevo etnograficamente três eventos nos quais o projeto de lei que cria a UNISUS foi debatido. A título de enumeração, o primeiro evento foi uma assembleia na qual o Projeto UNISUS foi apresentado pelas diretorias da Fundação de Ensino e Pesquisa em Ciências da Saúde (FEPECS) e ESCS. O segundo evento foi um debate para a discussão dos artigos do projeto de lei num âmbito interno antes que o mesmo fosse enviado ao Conselho de Saúde do Distrito Federal (CSDF) e à Câmara Legislativa do Distrito Federal (CLDF) com vistas a ser aprovado. E o terceiro evento foi uma plenária deliberativa do Conselho de Saúde do Distrito Federal (CSDF) para que o mesmo fosse votado ponto a ponto pelos conselheiros de saúde, figuras representativas de diversos órgãos relacionados à saúde local. Durante a narrativa dos eventos, faço um intervalo estatístico para mostrar a expressividade dos egressos do curso de graduação em medicina da Escola Superior de Ciências da Saúde (ESCS) no mercado de trabalho da assistência em saúde do Distrito Federal como forma de incrementar o argumento na medida em que o conteúdo da narrativa exigiu uma investigação quantitativa nesse sentido.

Na última parte do terceiro capítulo, teço algumas críticas quanto à falta de articulação de diversos atores sociais na condução dos processos democráticos no que concernem à discussão e implementação de projetos institucionais no que diz respeito ao processo de transformação institucional abordado tanto nas esferas da gestão e administração da vida pública quanto nas cearas ideológicas e políticas que o Projeto UNISUS acionou em várias esferas do pensamento social tais como: aos processos cotidianos imediatos dos encontros sociais e institucionais na vida pública do Estado; em relação à gestão da saúde e educação públicas nacionais e; à transposição da mais imediata realização da democracia nas arenas políticas para processos de transformação mais profundos em nossa sociedade no que diz respeito aos modelos de gestão pública e democrática de uma determinada instituição de ensino em medicina.

Finalmente, nas considerações finais, coloco em evidência as contribuições da dissertação nos diferentes níveis abordados, os quais formam uma etnografia documental, uma etnografia institucional e uma etnografia dos processos pedagógicos, cada uma contribuindo com um nível de análise. Retomo, ainda, as ideias principais discutidas ao longo de cada capítulo para estabelecer algumas profundidades que foram exploradas ao longo das análises. Destaco a questão dos processos pedagógicos enquanto campo prolífico para estudos 
etnográficos na área da formação de profissionais da saúde; a questão institucional também é destacada pela configuração de valores que a partir delas passam a existir e engendrar as interações entre seus membros; destaco a profundidade política que a dissertação aborda no que tange à gestão dos processos cotidianos da gestão democrática da vida pública; desataco ainda a profundidade ideológica do processo estudado e como ela foi essencial para a interpretação e compreensão do processo estudado; além disso, destaco a profundidade histórica revelada pelo processo abordado. 


\section{CAPÍTULO 1}

\section{DA GÊNESE POLÍTICA À POLÍTICA DE CRIAÇÃO}

Este capítulo começa com a apresentação de alguns elementos etnográficos da pesquisa de campo que posicionam o leitor no eixo de discussão e reflexão que esta dissertação busca empreender e volta primeiro ao passado para falar sobre um momento presente no qual um determinado processo de mudança tem acontecido em nossa sociedade no contexto da formação médica no Distrito Federal.

Com tal perspectiva, trago um trecho de reportagem publicada pelos veículos de comunicação da Secretaria de Estado de Saúde do Distrito Federal (SES-DF) no seu jornal institucional por volta da época de criação da Escola Superior de Ciências da Saúde (ESCS), instituição pública de ensino na área da saúde, localizada em Brasília, a qual compôs sítio etnográfico elementar durante o trabalho de campo:

\footnotetext{
Nesta nova e revolucionária faculdade os alunos terão a oportunidade de conhecer e trabalhar diretamente com ações de medicina preventiva, desenvolvidas nos centros de saúde, e, ao mesmo tempo lidar com a medicina de alta complexidade [...] Promoverá uma imediata ampliação na oferta de vagas na área de medicina [...] Formará profissionais absolutamente integrados à realidade socioeconômica local [...] Também demonstra, de forma cabal, que, ao contrário das inverdades constantes e injustamente difundidas por todo o Brasil, podemos afirmar categoricamente: o futuro em saúde começa aqui. (Saúde em Ação: Boletim Informativo da Secretaria de Saúde do Distrito Federal, Ano I n ${ }^{\circ}$, Setembro de 2000, 2)
}

À época da publicação desse boletim informativo, Jofran Frejat era o secretário de saúde do Distrito Federal enquanto Joaquim Roriz, filiado ao Partido do Movimento Democrático Brasileiro (PMDB) era governador. Médico de formação e ator político presente em várias instituições de saúde do Distrito Federal desde os anos 1970, Frejat foi diretor do Instituto Médico Legal do Distrito Federal também durante parte dos anos 1970, foi secretário geral do Ministério da Previdência Social, conselheiro da Fundação Hospitalar do Distrito Federal nos anos 1980 e foi eleito deputado federal em 1986 filiado ao Partido da Frente Liberal (PFL), fazendo parte da Assembleia Constituinte de 1988, marco histórico para a consolidação do Estado brasileiro moderno através da promulgação da "Constituição Cidadã", isto é, da Constituição Federal de 1988. No que diz respeito à gestão do Sistema Único de Saúde (SUS) 
no contexto do Distrito Federal, Jofran Frejat ocupou posições administrativas na gestão política da Secretaria de Estado e Saúde do Distrito Federal (SES-DF) por ter sido o próprio secretário de saúde do Distrito Federal durante boa parte dos anos 1990 tendo vindo da época de sua gestão a ideia de se implantar uma escola distrital de medicina em Brasília, isto é, a Escola Superior de Ciências da Saúde (ESCS).

A movimentação de um projeto público de educação em saúde através do qual buscavase a implantação de uma "faculdade revolucionária" que "forma profissionais integrados à realidade socioeconômica" e que proveria o "futuro da saúde" brasileira no contexto da orientação política de Roriz e Frejat, a qual tem conhecidamente caráter conservador e clientelista por parte da gestão governamental do Distrito Federal, é fator relevante para uma reflexão sobre as categorizações dicotômicas das formas de governo que incitam determinismos sobre os tipos de projetos públicos e processos políticos que acontecem em cada governo. Decorre que não é prudente estabelecer relações diretas de causa e efeito entre o caráter da gestão política de cada governador e os tipos de projetos que se concretizam durante seus mandatos. Sugerir que em épocas de governos conservadores exista necessariamente o abatimento da suplementação de projetos institucionais "inovadores" no âmbito público com base apenas nas posições partidárias ou orientações políticas não ajuda na compreensão do que estava em jogo na época da criação da Escola Superior de Ciências da Saúde (ESCS). A iniciativa da construção dessa "faculdade revolucionária", isto é, a ESCS, no contexto governamental clientelista e conservador de Joaquim Roriz e Jofran Frejat no Distrito Federal mostra que categorizações dicotômicas quanto às inclinações partidárias ou tendências políticas dos governos não dão conta de explicar processos institucionais como os que trato nesta dissertação.

O boletim da Secretaria de Saúde do Distrito Federal (SES-DF) citado evoca a ideia geral de "inovação" ao incitar o "futuro" da saúde no Brasil e faz ode à implementação da nova escola de medicina que estava em vias de ser criada, isto é, a Escola Superior de Ciências da Saúde (ESCS). Essa escola vinha com uma proposta de gestão política e pedagógica que articulava vínculos estreitos entre o ensino da medicina e os serviços públicos de saúde e previa a utilização das unidades locais de atendimento do próprio Sistema Único de Saúde (SUS), os "cenários da prática", para as atividades de ensino e aprendizagem médicas. Visto isso, a escola era considerada "revolucionária" por trazer uma metodologia de ensino diferente dos métodos 
tradicionais que outras faculdades de ciências da saúde no Distrito Federal tinham na época. Configurava-se, assim, que a escola vinha com peso político e ideológico atrelado que se dava pela natureza de seu projeto pedagógico, cujos dois pontos principais eram a Aprendizagem Baseado em Problemas (ABP) e o fato de que as atividades de ensino e aprendizagem acontecerem nas unidades de atendimento da própria rede assistência de saúde do Distrito Federal.

Todavia, a Escola Superior de Ciências da Saúde (ESCS) nasceu dentro de um campo de disputas de forças em torno do manejo das políticas voltadas para a saúde e isso fazia seu projeto ser perpassado por uma série de interesses e de críticas quanto à sua implantação no Distrito Federal. Em uma reportagem publicada em 2001 pelo jornal Correio Brasiliense poucos meses antes de a nova escola ser inaugurada pôde-se ler:

O projeto, no entanto, esbarra em uma série de críticas. A primeira: Brasília não
precisa de mais médicos [...] afirmou o presidente do Conselho Regional de Medicina
(CRM) [...] O problema é que apenas metade dos profissionais trabalham na rede
pública. [...] 'A solução não é criar mais médicos, mas inserir os que já existem no
sistema público', acredita. Poderíamos ter feito algo bem melhor juntos. O recurso
público é o mesmo, a sociedade ganharia mais se, ao invés de dividi-lo, somássemos
os esforços', acredita a diretora da Faculdade de Saúde [da UNB]. Ela e os presidentes
do CFM e CRM/DF concordam que o ideal seria deixar o ensino com a UNB e investir
em uma política de saúde, com aprimoramento do mercado de trabalho e valorização
do profissional. 'Só que isso não renderia os mesmos votos de uma escola médica.
[...] É um projeto politiqueiro'. (Correio Brasiliense, $06 / 03 / 2001,9$ )

Essa reportagem explicita, em contraste com o boletim da Secretaria de Saúde do Distrito Federal (SES-DF) citado anteriormente, que apenas o anuncia, o conflito de opiniões e jogos de acusações em torno do projeto de criação da nova escola de medicina e é sobre aspectos desta ambivalência que os parágrafos seguintes são dedicados.

O projeto de criação da Escola Superior de Ciências da Saúde (ESCS) estava inserido num campo de disputas em torno de sua política e implementação. Os Conselhos regional e federal de medicina desfavoreciam a criação da nova escola, mas o governo local continuou a mover o projeto de lei que criava a ESCS apesar da resistência das esferas corporativas médicas na época. Para os Conselhos de medicina (CFM e CRM), instituições reguladoras e representativas do corpo médico no país e no distrito, o ensino da medicina no Distrito Federal deveria continuar nas mãos da Universidade de Brasília (UNB) e, segundo eles, os investimentos do governo deveriam ser feitos no próprio sistema de assistência e nas políticas de saúde afim de atrair mais médicos para trabalharem na rede pública de saúde, e não criar 
mais uma faculdade. Assim, existia a força das corporações que tinham influência nos programas curriculares dos cursos de medicina através da implementação de modelos pedagógicos centrados nas disciplinas biológicas, especialidades médicas e, por outro lado, nas áreas adjacentes às forças dos interesses corporativos, existia ainda o interesse dos gestores políticos no processo de criação da ESCS com vistas a suplementar o sistema de saúde local com mais médicos formados a partir de lógicas voltadas à atenção básica através de metodologias de ensino diferenciadas.

Considerando os conflitos e divergências em torno da criação da nova instituição, optouse por ver a Escola Superior de Ciências da Saúde (ESCS) como ponto fulcral de uma rede de instituições sociais que era perpassada por numerosas e diversas linhas de ações, forças e conflitos de interesses que existiram no processo de sua criação. Para as camadas corporativas médicas, conforme a reportagem do Correio Brasiliense, um dos principais jornais de Brasília, não era a política pedagógica ou o projeto de ensino trazido pela nova escola o problema maior na visão deles, mas era a relutância quanto à ideia de que a criação de mais uma faculdade de medicina e a consequente formação de mais médicos não seriam capazes de solucionar os problemas do serviço público de assistência em saúde, supondo que que isso teria impactos negativos no mercado de trabalho médico profissional. Por outra lado, para o governo local, a nova escola era vista como sinônimo de futuro e transformação do ensino em medicina e emblemática de valores que corroboravam para o desenvolvimento e crescimento da saúde pública brasileira.

Deslocando agora a problemática para o presente etnográfico, apresento o trecho de um pronunciamento público feito pelo secretário-adjunto da Secretaria de Estado e Saúde do Distrito Federal (SES-DF) em novembro de 2013, discurso registrado no diário de campo na ocasião de uma solenidade oficial, que aconteceu na Câmara Legislativa do Distrito Federal (CLDF), para a comemoração do aniversário de 12 anos da criação da ESCS:

Não se deve esquecer das razões que motivaram a criação dessas escolas, que sempre
foi a unificação entre serviço e educação em saúde, porque esta lógica e esta
pedagogia vem de dentro do contexto político de gestão da própria Secretaria de Saúde
que, apesar dos projetos e das ideias serem antigas, elas ainda são modernas. Em
qualquer processo de implantação de qualquer projeto existem dificuldades pois
muitas forças são envolvidas. A prosperidade é da própria sociedade civil e não
podemos perder o norte das representações, que não podem ser excluídas de
determinadas categorias ou grupos. A decisão deve ser tomada de forma ampla, pois
é essa a forma de se construir um futuro. Nada neste processo deve ser feito a portas
fechadas, pois são iniciativas de interesse da sociedade civil em nome de sua melhoria 
e, em nome também, da formação de um 'médico total', tendo visto a metodologia que foi adotada. (Secretario adjunto da Secretaria de Saúde do Distrito Federal. Fala registrada no diário de campo em 13/11/2013)

A fala citada traz alguns apontamentos para questões que dizem respeito ao nexo das mudanças e transformações atuais que vem acontecendo com a formação médica no âmbito do Distrito Federal. Destaco que a Escola Superior de Ciências da Saúde (ESCS) foi pensada sobre a ideia de "unificação entre serviço e educação em saúde" em duas instâncias: primeiro, nos processos de ensino e aprendizagem em si, caracterizados pela metodologia do Aprendizado Baseado em Problemas (ABP) e segundo, na configuração da gestão institucional pública, que vincula as gestões da educação e saúde públicas. A administração estatal acaba criando nessa interface um contex to inédito para a educação médica no Distrito Federal por integrar diferentes dimensões da gestão da saúde pública e trazer um projeto educacional "revolucionário" enquanto valor. Essa integração vinha agregada de valores ideológicos através da ideia de "construção do futuro da saúde brasileira" através da criação e implantação de projetos educacionais em saúde no âmbito da administração pública.

O secretário ainda disse que o processo para a implantação deveria ser feito a portas abertas. Uma vez que a relação objetivada é com a sociedade civil, isso expressa que a criação desse projeto educacional é situado nas arenas da democracia, que são em si conflituosas, pois existem nelas muitas forças e interesses envolvidos e que, na sua visão, isso seria um desafio que deveria ser enfrentado abertamente e não deveria ser abafado ou silenciado das esferas públicas de discussão com a sociedade civil. Os valores evocados na sua fala se voltaram às bases democráticas dos processos públicos que asseguram o "interesse da sociedade civil" em prol de um futuro próspero no qual haverão "melhorias" sociais com a formação de "médicos totais" através de uma metodologia de ensino e gestão diferenciadas que integrem o ensino e o serviço de saúde em vários níveis de seus processos.

O "futuro" foi a categoria central ao falar do desenvolvimento dessa instituição e da sua contribuição para o desenvolvimento da saúde no Brasil e no Distrito Federal. Isso se implica na ideia de que formar médicos com um perfil específico, isto é, com o perfil do "médico total", formado com uma metodologia de ensino que lhe proporcionaria maior autonomia nos processos de aprendizagem e com foco na atenção básica, forneceria capital simbólico para a legitimação da Escola Superior de Ciências da Saúde (ESCS) enquanto instituição que tem relevância prática, política e ideológica. 
Sem embargo, há uma tensão estabelecida entre a gestão da saúde através das políticas públicas perante a implementação de um projeto pedagógico em uma instituição um tanto quando inédita de ensino em medicina no Distrito Federal - considerando localmente seu processo de criação e a força dos valores e ideais da saúde pública brasileira alicerçados pelos princípios de "universalidade", “descentralização", "participação", “equidade" e “integralidade”, dispostos na Constituição Federal de 1988 (CF88), documento de enorme valia para a figuração da força do Estado brasileiro até hoje. Esses valores também estão dispostos na Lei 8.080 de 1990, que institui o Sistema Único de Saúde (SUS), imputando dever ao Estado de formular e executar políticas públicas de atenção à saúde no contexto na nação brasileira em sua totalidade e para todos.

É possível ver a atualidade do debate sobre a expressividade (ou até necessidade) de novos modelos de formação médica no último informe da reunião da Associação Brasileira de Saúde Coletiva (ABRASCO). O informe do evento, cujo nome foi "Formação Profissional em Saúde \& Ensino da Saúde Coletiva”, realizado em Porto Seguro na Bahia em 2014, traz o relato de uma das reuniões na qual se discutira sobre a formação de recursos humanos para a saúde pública brasileira:

\begin{abstract}
A professora [...] destacou a baixa literatura sobre o assunto, e que cabe ao conjunto dos pesquisadores ampliarem os estudos sobre a questão, a começar com a avaliação dos parâmetros curriculares. 'Apesar de conceitos como atenção básica e visão crítica e humanista estarem bonitinhos nos parâmetros curriculares, não formamos como devíamos'. [...] Uma das ferramentas que [a professora] vê como elemento que possa trazer mudanças a esse cenário são os novos cursos que despontam, oferecendo formações fora dos padrões tradicionais, como os próprios cursos de saúde coletiva e os bacharelados interdisciplinares, nos quais os estudantes tem uma formação, não só na área de saúde, mas também nas de humanidades e artes e posteriormente escolhe um curso da área de saúde para a formação específica. Para ela, o sucesso desse modelo, oferecido na Universidade Federal da Bahia (UFBA) e a Universidade Federal do Recôncavo Baiano (UFRB) são elementos que apontam para a necessidade de uma nova Reforma Universitária, não apenas visando a ampliação de vagas, mas sim a construção de um novo desenho de formação dos profissionais de saúde, um debate que precisa ser travado com dirigentes governamentais, reitores, docentes e pesquisadores. 'É fundamental inserir o tema na agenda política do país', completou [...]. (ABRASCO, 2014, 2)
\end{abstract}

O informe traz a fala de uma professora de medicina durante um debate realizado entre intelectuais da área medicina e saúde coletiva sobre a questão da implementação de carreiras profissionais voltadas para o Sistema Único de Saúde (SUS). Menciona-se a necessidade de implantação de currículos diferenciados tendo visto as inadequações dos modelos tradicionais de formação em medicina que o Estado vem fomentando na atualidade no caso das faculdades 
baianas. Vale destacar que o evento, cuja fala foi mencionada acima, aconteceu na Bahia e tendeu à discussão da expressividade e necessidade de novos modelos de educação em medicina no contexto desse estado, mas a questão da renovação do ensino em medicina vai além.

Isso em mente, neste trabalho considera-se a Escola Superior de Ciências da Saúde (ESCS), além de um ponto convergente de diferentes linhas de ação e interessa, como uma expressão específica e localizada dessa discussão mais ampla quanto à necessidade de criação de novas instituições de ensino em medicina com a implantação de modelos diferenciados de ensino em medicina no contexto brasileiro, não esgotando as alternativas em jogo no cenário nacional. Ao longo da dissertação dou atenção às estruturas e redes interinstitucionais atuais nas quais a pesquisa se inseriu e que chamaram atenção para os quadros complexos de relações de poder e de interesses que, para fins analíticos, mereceram espaço reservado no texto, pois não seria tarefa simples apresentá-los em poucos parágrafos.

Atualmente a Escola Superior de Ciências da Saúde (ESCS) é uma escola mantida pela Fundação de Ensino e Pesquisa em Ciências da Saúde (FEPECS), esta que, na época da pesquisa de campo, era presidida pelo próprio secretário de saúde da Secretaria de Estado de Saúde do Distrito Federal (SES-DF). A gestão administrativa da escola atualmente é levada a cabo em meio à uma série de interesses políticos das esferas maiores do governo do Distrito Federal (GDF) que se expressam no sentido da polêmica atual em torno da incerta criação da função de reitor caso a Universidade de Ciências da Saúde do Distrito Federal (UNISUS) seja criada. Considerando que os estudantes e docentes veem vantagens na criação da nova universidade, a criação da função do reitor se figura como um dos pontos de maior dissenso porque, pelo menos em tese, um reitor estaria muito mais próximo das demandas e questões internas da universidade do que um secretário de saúde, tal como à época da pesquisa a FEPECS era presidida. A centralidade dessa questão dentro do processo de transformação institucional se expressa na fala de um estudante:

Existem correntes dentro da Secretaria e dentro do Conselho de Saúde que não acreditam que a ESCS tenha cumprido o papel social, alegando que nossos alunos continuam hospitalocêntricos e distantes do SUS [...] Acho que nosso foco agora deve ser a respeito do reitor e só e somente isso. Se ela for aprovada, depois nós tentamos mexer no resto. Quem foi à reunião do Conselho de Saúde viu que nem todos os conselheiros apoiam a ESCS; pelo contrário, muitos desejam realmente nos ver fechados e não como uma universidade. (Estudante de medicina da ESCS. Fala registrada no diário de campo, 22/10/2013) 
O estudante faz menção a uma reunião deliberativa do Conselho de Saúde do Distrito Federal (CSDF) no auditório da própria escola e que será abordada com detalhes no último capítulo, e adianto ao leitor que nessa reunião foi debatido o projeto de lei de criação da UNISUS. O ponto sobre se seria criado a função de reitor foi tão polêmico entre os conselheiros de saúde ao ponto de fazer com que a reunião fosse encerrada em meio a discussões e trocas de provocações agressivas entre os membros do conselho de saúde, a diretoria da escola e os estudantes. O conflito nessa reunião foi revelador de complexidades e estruturações importantes para que fosse possível compreender melhor a questão institucional abordada. Uma descrição completa desse evento encontra-se no terceiro capítulo.

Por enquanto, mantendo o fio argumentativo, apresento a fala de outro estudante do curso de medicina da Escola Superior de Ciências da Saúde (ESCS) quanto ao conflito de interesses políticos dos gestores frente aos efeitos sociais e práticos da implementação de uma instituição de ensino superior que insere uma instituição de ensino em medicina nas estruturas de gestão do Sistema Único de Saúde (SUS) no Distrito Federal:

\begin{abstract}
A história dos estudantes da ESCS é uma história de muita luta. Ainda mais por conta da briga que sempre existiu entre a ESCS e a FEPECS que, hoje em dia, foi meio que superada, mas que no que diz respeito aos interesses de cada instituição ainda existe muita rixa. Antes não existia diálogo entre as duas e isso transparecia pros estudantes porque podíamos ver que Secretaria não estava nem aí pro projeto educacional que a escola tem. [...] Quando os estudantes 'vestem a camisa' da Escola isso parece tornar a identidade contagiosa, porque a ESCS de hoje, para os estudantes e alguns docentes, tem cara de família. A gente se identifica com isso aqui mas a Secretaria de Saúde ainda não aprendeu a identificar a gente. Mas para mudar o SUS é preciso mudar o tipo de profissional que entra no SUS e a escola faz isso. A ESCS provoca um impacto positivo no serviço [de saúde] que é a formação de profissionais mais proativos e preparados para a realidade do SUS nas atividades que realizam, porque isso está nas veias e está na história da escola esse saber sobre como funciona o SUS por dentro. (Estudante de medicina da ESCS. Fala registrada no diário de campo, 13/11/2013. Grifo meu.)
\end{abstract}

Quando o estudante diz que "a gente se identifica com isso aqui mas a Secretaria de Saúde ainda não aprendeu a identificar a gente" ele mostra como é conflituosa a posição da Escola no sistema institucional do qual faz parte tanto no que diz respeito ao seu reconhecimento enquanto uma instituição que alargou-se politicamente dentro da rede na qual existe, quanto às questões da pedagogia adotada e de sua gestão administrativa. Na fala do estudante, esse conflito de interesses e a ideia de luta por espaço político da escola na rede pública se expressava no fato de ele fazer menção à uma identificação interna dos membros da ESCS entre si e com o projeto da Escola enquanto uma instituição pública de ensino em saúde 
a qual a Secretaria de Estado de Saúde do Distrito Federal (SES-DF), na instância maior das decisões políticas de Estado, parecia não a reconhecer, o que acarretava conflitos que vieram à tona num momento específico de transformação institucional, política e administrativa em torno do projeto de transformação da ESCS em UNISUS.

Quanto à formação de um determinado grupo social no qual que seja possível identificação mútua entre seus membros, Bourdieu (1982) propõe que os contornos definidos de qualquer grupo social que se auto reconheça enquanto tal precisa se firmar em princípios classificatórios de pertencimento que produzam determinadas qualidades que alavancam propriedades políticas manipuláveis por cada membro do grupo. Isso permite a capacidade de resistir àqueles que, porventura, neguem a legitimidade de um grupo social que busca perpetuar seus princípios e qualidades genéricas. Considerando tal perspectiva analítica observo que, por um lado, a pedagogia inovadora da Escola Superior de Ciências da Saúde (ESCS) faz com que ela seja exemplo tanto prático quanto ideológico de um novo modelo de formação médica que se volta para a atenção assistencial primária com abordagem social; e ainda, isso condiz com a política nacional para a formação de recursos humanos para trabalhar no Sistema Único de Saúde (SUS), o qual pode ser visto como um dos pilares da ideia de uma integração à nível nacional através dos serviços de saúde, e mais recentemente, dos ideais de democracia participativa e inclusão social.

Aqui a categoria "participação" vem atrelada à ideia de Estado e de valores morais inerentes à ideia da "nação brasileira" e "cidadania", e a ideia de "integração" diz respeito às características do projeto político pedagógico da Escola enquanto modelo educacional que autonomizam os estudantes nos processos de aprendizagem e também enquanto modelo de gestão pública. Ainda que a ideia de participação signifique uma integração de ações em prol de algo comum, por outro lado as relações políticas e institucionais entre os atores sociais que envolvem a Escola Superior de Ciências da Saúde (ESCS) fazem dela objeto de disputas e interesses que são além de administrativos, ideológicos. Desta forma, a legitimação da ESCS se desloca para a relação implicada na qualidade da relação entre o mundo do ensino em medicina e o mundo do trabalho médico tanto no nível administrativo, quanto no nível ideológico e moral do seu Projeto. Ou seja, os dois maiores fatores relevantes a serem considerados são a vinculação original que o projeto pedagógico da ESCS tem com as políticas assistenciais de atenção básica através de uma abordagem socialmente envolvida enquanto 
ideologia e o projeto político da ESCS enquanto desafiadora dos modelos de gestão dos serviços de saúde e do ensino superior em saúde através da integração dessas esferas.

A intermediação de uma determinada forma de ensino com o viés social da atenção básica dentro do próprio sistema público de saúde local confere capital moral para a legitimação da ESCS enquanto instituição pública de ensino constituída dentro das estruturas políticas da administração pública da saúde no Distrito Federal e concorda com os conteúdos ideológicos da saúde pública do Brasil como um todo. Isso faz a ESCS ser parte de um movimento ideológico e político mais amplo relacionado ao modelo democrático de gestão que se materializou com maior expressão após a Constituição Federal de 1988, a qual abriu terreno fértil para a criação de novos projetos públicos de gestão da saúde pública e educação em saúde no contexto brasileiro desde então.

Esta dissertação aborda o processo de criação e discussão do projeto de lei que visava transformar a Escola Superior de Ciências da Saúde (ESCS) na nova Universidade de Ciências da Saúde do Distrito Federal (UNISUS), que aconteceu de maneira polêmica entre os envolvidos com o processo de transformação. A negociação do projeto de lei da UNISUS pelas arenas políticas e a forma como o mesmo foi discutido é um dos objetos desta pesquisa, pois o processo institucional acompanhado permitiu vislumbrar como a ação do Estado se apresentou durante processos de idealização e implementação dessa instituição educacional em saúde adotiva de modelos de formação e gestão "inovadores" e "revolucionários" no contexto atual. O retorno ao momento de criação da Escola Superior de Ciências da Saúde (ESCS) no capítulo 2 e uma etnografia de sua transformação em Universidade de Ciências da Saúde do Distrito Federal (UNISUS) no capítulo 3 permitiu ver a atualidade e permanência das disputas na discussão conturbada em torno do desejo da instituição por maior autonomia através da criação da função de reitor, questão que mostrou os limites das discordâncias entre cada ator social envolvido com o processo de transformação institucional. Antes de retornar à época de criação institucional, outro processo histórico permite ver que o ensino em medicina faz parte de um projeto de nação e perceber o lugar de relevância da medicina e seu ensino na consolidação do Estado brasileiro, horizonte de reflexão neste capítulo inicial.

O objetivo deste capítulo é mapear a imbricação entre o horizonte de relações entre o ensino em medicina e a ideia de nação brasileira. A proposta é fazer um esforço teórico e reflexivo no qual a criação da Escola Superior de Ciências da Saúde (ESCS) em Brasília e a 
integração da gestão entre as políticas de saúde e políticas de educação sejam expressão de um processo de mudança para além das práticas de formação médico-profissionais. Esse processo vai ao encontro de um projeto de nação cuja uma de suas bases foi a consolidação de um sistema de assistência em saúde à nível federal, conforme mostro logo à frente.

\section{O ESTADO E SEUS IDEAIS}

Entende-se por "Estado" aqui aquilo que vai além estruturas e práticas políticas das esferas de gestão pública e a noção inclui o caráter ideológico que carrega consigo. Segundo Abrams (1988), uma divisão entre a estrutura das relações políticas e a ideologia que lhes perpassam não faz sentido porque o Estado - não apenas como estrutura administrativa, mas como entidade ideológica também - se mostra como uma entidade comum à totalidade de indivíduos que lhe são submetidos coletivamente. Compartilho da visão na qual o autor define a noção de Estado da seguinte maneira:

[...] o Estado emerge [...] como uma coisa ideológica. Ela pode ser entendida como o mecanismo no qual a sujeição é legitimada; como uma coisa ideológica ela pode ser mostrada a funcionar dessa maneira. Ele apresenta poderes politicamente institucionalizados para nós de forma que é de uma vez integrada e isolada e por satisfazer essas duas condições ele cria para nossa forma de sociedade uma base aceitável de aquiescência. Ele presta conta de instituições políticas em termos de coesão, propósito, independência, interesse comum e moralidade sem necessariamente nos dizer nada sobre a verdadeira natureza, significado ou funções das instituições políticas. [...] O Estado é, então, em todo sentido do termo, um triunfo do encobrimento. Ele encobre a história real e as relações de sujeição por trás de uma máscara a-histórica de ilusão legitimadora; inventa para negar a existência de conexões e conflitos que seriam, se reconhecidos, incompatíveis com a reivindica autonomia e integração do Estado. O segredo oficial real, contudo, é o segredo da não existência do Estado. [...] O Estado não é uma realidade que fica por detrás da máscara das práticas políticas. Ele é em si a máscara que nos impede de ver a prática política como ela é. Ele é, podemos dizer, a mente de um mundo sem mente, o propósito de condições despropositais, o ópio do cidadão. [...] um nexo palpável de práticas e estruturas institucionais centradas em governo e mais ou menos extensivas, unificadas e dominantes em qualquer sociedade. (Abrams, 1988, 68-82)

$\mathrm{Na}$ perspectiva enunciada, o Estado seria o emblema de algo maior e que é compartilhado de maneira ampla entre aqueles que estão sob sua égide e lhes confere condições ideológicas para que haja sentido e direcionamento nas praticas políticas em nome de interesses valorativos e morais em comum. Assim, em nome de algo que não existe concretamente e que fica no mundo das ideias, o Estado se implica nas práticas cotidianas da vida política de maneira profunda. Em outras palavras, o Estado é uma entidade abstrata em nome da qual as práticas 
políticas encontram o sentido de sua existência e o direcionamento de suas iniciativas; e apesar de tais práticas serem em si repletas de conflitos, o Estado, como um ente ideológico, se apresenta como uno e constituído em torno da ideia de unidade, de integração, de um senso de comunidade e pertencimento aos seus membros, por mais que esses discordem entre si. Nesse sentido, portanto, o Estado não deve ser considerado apenas como uma estrutura administrativa de gestão, ele é uma entidade ideológica agregadora a partir e em torno da qual a vida política e pública acontece.

Outro autor que define a noção de Estado e, mais precisamente, de nação, é Anderson (1982). O autor fala que a ideia de nação, isto é, de uma comunidade limitada e soberana que confere valores e senso de comunhão entre seus cidadãos sem que eles tenham elos reais entre si, faz com que haja compartilhamento de valores em nome da consolidação de uma espécie de união e comunhão que faz seus membros se imaginarem numa comunidade. Segundo o autor, a noção de nação tem a seguinte definição:

\begin{abstract}
Ela é imaginada porque mesmo os membros da mais minúscula das nações jamais conhecerão, encontrarão, ou sequer ouvirão falar da maioria de seus companheiros, embora todos tenham em mente a imagem vida da comunhão entre eles. [...] Imaginase a nação limitada porque mesmo a maior delas [...] possui fronteiras finitas, ainda que elásticas, para além das quais existem outras nações. Nenhuma delas imagina ter a mesma extensão da humanidade. [...] Imagina-se a nação soberana porque o conceito nasceu na época em que o Iluminismo e a Revolução estavam destruindo a legitimidade do reino dinástico hierárquico de ordem divina. [...] as nações sonham em ser livres e [...] A garantia e o emblema dessa liberdade é o Estado Soberano. [...] E, por último, ela é imaginada como uma comunidade, porque, independentemente da desigualdade e da exploração afetivas que possam existir dentro dela, a nação sempre é concebida como uma profunda camaradagem horizontal. (Anderson, 1982, 32-4)
\end{abstract}

A ideia de Estado-nação, na perspectiva de Anderson (1982), é algo imaginado, portanto, se trata de uma ideia; é limitado, isto é, possui fronteiras que definem sua amplitude político-geográfica; é soberana, por conta do processo histórico de seu próprio surgimento e aquisição de caráter laico; e se trata de uma comunidade, o que implica senso de comunhão e pertencimento.

Com a perspectiva desse autores em mente, a definição de Estado que utilizo nesta dissertação vai além da noção de que o Estado é uma máquina administrativa estruturada e vai em direção à noção de que ele é uma entidade ideológica e imaginada a qual dispõe de uma série de valores morais que se apresentam como uma unidade coesa, apesar de haver conflitos que existem internamente entre os cidadãos e instituições que nele existem e se relacionam e 
entre as ideias e valores daqueles que dele fazem parte. Essa discussão teórica acerca da construção do Estado moderno permite compreender como que políticas públicas voltadas para a educação em saúde são idealizadas, discutidas e executadas no contexto de administração do Estado e alimentam ideologias em torno de uma entidade comum que a ideia de nação traz.

A própria ideia de integração é uma forma de configuração social que vai além das intencionalidades dos sujeitos e coloca a ênfase no aspecto relacional, isto é, dos elos de interdependência que as estruturas que o próprio Estado administra e media através tanto de meios administrativos e estruturais quanto por intermédio da força unificadora e comunitária trazidas pelo Estado. A centralidade do Estado no controle dos projetos que concernem às políticas voltadas para os serviços públicos de saúde, entendida como veículo da ideia ampliada que se tem de "nação" e de "cidadania", vem atrelada à ideia de integração e pertencimento social através de uma ideologia que é mais ou menos homogênea, como mostrei anteriormente quando discuti a noção de Estado enquanto ente ideológico agregador e que encobre determinadas dissidências internas. Assim, o Estado vem mediar elos de interdependência amplos a partir do momento em que o processo de urbanização e de industrialização exigiam a coordenação de uma estrutura social que se tornava cada vez maior e mais complexa. O Estado surge nesse contexto, isto é, quando a criação de elos de interdependência sozinhos não deram mais conta dessa complexidade estrutural e social que foi sendo construído na virada do século XIX para o XX, época de grande expansão industrial e populacional em todo o mundo.

O papel do Estado no controle dos projetos que concernem às políticas voltadas para os serviços públicos é também bem trabalhada por Norbert Elias (1939) e por Abram de Swaan (1988). Eles abordam desdobramentos do surgimento do Estado e seus efeitos nos elos de interdependência social e política existentes e inerentes à sociedade moderna. A perspectiva dos dois autores preparam o caminho analítico para que se apreenda como que determinados elos de interdependência são constituídos através do controle das esferas sociais e políticas de poder presentes nas máquinas gestoras dos assuntos públicos.

Elias (1939) mostra que as relações políticas e sociais existentes no entrelaçamento social dos diversos atores no contexto moderno de consolidação dos estados nacionais foram impulsionadas por tensões que geraram conflitos dentro dos processos de mudança política e social que aconteceram no curso do desenvolvimento da civilização moderna e cujo controle 
do Estado sobre as questões da vida pública se tornou parte significativa e cada vez mais presente. $\mathrm{O}$ autor diz o seguinte:

Leva algum tempo até se descobrir que os Estado-nação fazem a sua aparição na sociologia contemporânea sob um disfarce particular. As referências a eles são mascaradas por um tipo de abstração, escondem-se atrás de conceitos como 'totalidade social', 'sociedade total' e, sobretudo, 'sistema social'. [...] uma pesquisa sobre os processos de formação de Estados e construção de nações no longo prazo pode mostrar que cada surto de integração de grupos humanos antes independentes, ou menos dependentes, ou menos reciprocamente dependentes, conjuga-se uma série de tensões e de conflitos específicos, lutas de equilíbrio e de poder que não são acidentais, mas estruturalmente concomitantes como um movimento em direção à maior independência das 'partes' de um 'todo'. [...] Em outras palavras: os Estados fizeram-se 'nacionais' em conexão com mudanças específicas na distribuição de poder entre governantes e governados, e entre os estratos sociais de suas sociedades - o que afetou a natureza própria da estratificação (Elias, 1970, 157-160)

O processo civilizador e surgimento dos Estados se deu através de um longo processo de rupturas históricas complexas na Europa, Estados Unidos e América Latina. Olhar para elos de interdependência mútua que vieram a ser instaurados pelo manejo de projetos políticos do Estado mostra que as relações entre os atores envolvidos com os projetos públicos no âmbito estatal colocavam face a face e em caráter de deliberação das políticas sociais abrangentes diversas instituições da sociedade num campo de interdependência mútua baseado nas tensões da própria estrutura social. Elias (1939) coloca o seguinte:

\footnotetext{
O que aqui se coloca no tocante ao processo civilizador nada mais é do que o problema geral da mudança histórica. Tomada como um todo, essa mudança não foi 'racionalmente' planejada, mas tampouco se reduziu ao aparecimento e desaparecimento aleatórios de modelos desordenados $\mathrm{O}$ estudo desses mecanismos de integração, porém, também é relevante, de modo mais geral, para a compreensão do processo civilizador. Só se percebermos a força irresistível com a qual uma estrutura social determinada, uma forma particular de entrelaçamento social, orienta-se, impelida por suas tensões, para uma mudança específica, e assim, para outras formas de entrelaçamento, é que podemos compreender como essas mudanças surgem na mentalidade humana. (Elias, 1939, 195)
}

Swaan (1988) revigora a perspectiva de Norbert Elias dizendo que houve uma espécie de generalização dos elos de interdependência dentro do Estado no contexto moderno e que, se olharmos para estes elos, desejáveis ou indesejáveis do ponto de vista particular de cada ator ou instituição envolvida, compreende-se as fontes e os efeitos das ações da coletividade frente as entidades estatais voltadas para o desenvolvimento da sociedade e dos países. No processo de coletivização das práticas sociais, típico do surgimento do Estado, Swaan (1988) coloca que a ação coletiva é capaz de coordenar as atitudes de seus membros e de estabelecer um bem coletivo que diz respeito a este plano de integração mais ampliado. Se perguntando como os 
arranjos coletivos afetam a sociedade estatal, ele traz a questão das interdependências com as seguintes palavras:

\begin{abstract}
Como e porque as pessoas desenvolveram arranjos coletivos, nacionais e obrigatórios para lidar com deficiências e adversidades que apareceram para afetar-lhes separadamente e clamam por soluções individuais? Dois argumentos, cada um pertencendo a uma tradição intelectual, juntos levam a uma resposta. Um se relaciona ao conceito de 'efeitos externos', como é usada na economia do bem estar social. [...] Esse conceito proporciona a ligação com um modo mais formal de análise de interesses coletivos divergentes, [...], na sociedade. O outro argumento é conectado com a sociologia histórica de Norbert Elias [...]: se refere à extensão e intensificação das 'cadeias humanas de interdependência' no curso do tempo; o conceito de 'formações humanas' é central nesta abordagem. Uma 'formação' é um padrão estruturado e em transformação de seres humanos interdependentes. [...] A ideia de 'generalização da interdependência' ajuda a explicar as mudanças nos padrões de comportamento e modos de experiência nos termos das transformações sociais a longo prazo. (Swaan, 1988, 2. Tradução minha.)
\end{abstract}

Vale lembrar que Foucault (1979) fala do adensamento do controle disciplinar inerente aos processos de insuflação do controle estatal de modo ampliado que foi sendo enraizado por entre as estruturas de poder dentro da sociedade moderna. Ele ainda mostra os efeitos de controle sobre os saberes ao traçar o nascimento clínica médica moderna com o surgimento das primeiras faculdades de medicina modernas e o modo com que o ensino da medicina ocidental moderna foi sendo fundamentado através das políticas de Estado que atuavam de maneira controladora quanto às atividades médicas e assistenciais. Ao passo que Elias (1939) remete às tensões que movimentam um processo civilizador de formação e figuração do Estado na medida em que, na composição do movimento de integração mais ampliada, consolidam os poderes disseminados do Estado através de redes de coletividades integradas socialmente. Swaan (1988), por sua vez articula diferentes perspectivas teóricas quanto à formação das políticas sociais do Estado ao dizer que há de fato uma generalização dos elos de interdependência por toda a amplitude sob a égide o Estado ao mesmo tempo que existe também um universo composto por efeitos e forças externas que ligam a economia de mercado ao gerenciamento dos bens públicos, configurando um sistema de relações institucionais que movimentam e gerenciam os projetos do próprio Estado.

Trazendo a discussão sobre Estado para a questão da prática médica, nos prelúdios do século XX começaram-se a ser estreitados os mecanismos de poder e de controle dos Estados sobre as práticas médicas. Com a intensificação da urbanização das cidades e com a conjuntura 
política de novas instâncias de administração da vida social que marcaram a época, Analisando historicamente o avanço do controle do Estado sobre a saúde pública na França, na Inglaterra e na Alemanha, Foucault $(1963,1979)$ chama de "medicina social" ou "medicina do estado" a medicina que fez parte do surgimento dos Estados Nacionais modernos. Ao descrever o contexto alemão, Foucault (1979) mostra que, devido à transformação nas estruturas governamentais após a unificação da nação e devido ao desenvolvimento científico e cultural que caracterizou a época, as atividades da máquina pública nacional na Alemanha se intensificaram e as práticas de controle em relação à educação, à saúde, à segurança, à vigilância da população, passaram a ser assuntos abordados por uma ótica social, populacional, e enfim, nacional. Em relação à saúde, o autor coloca, passou a ser necessário "um sistema muito mais completo de observação da morbidade do que os simples quadros de nascimento e morte" (Foucault, 1979, 83), estes característicos da "medicina individual" até o final do século XIX. O autor diz que na Inglaterra o contexto histórico da saúde púbica na época foi caracterizado por uma "medicina das camadas desfavorecidas", consolidada pela "lei dos pobres" (Foucault, 1979, 95), cuja institucionalização foi consequência do aumento da migração de pessoas que viviam nos campos para os centros urbanos que começaram a se adensar durante a intensificação da urbanização europeia. A presença de migrantes nas grandes cidades inglesas contribuía para o agravamento do contraste socioeconômico entre ricos e pobres e da situação sanitária dos grandes centros, conjuntura que serviu para a criação de um sistema sanitário que separava os nichos socioeconômicos através do controle da circulação e do isolamento social, o que, consequentemente, segregava as classes sociais e impunham-lhes determinadas restrições assistenciais que cabiam a cada uma segundo o poder centralizador do Estado. Já na França o autor diz que emergiu no final do século XIX a necessidade de ser instauradas determinadas formas de "controle" e de "normalização" (Foucault, 1979, 84) das práticas e dos saberes médicos com a intenção determinada das camadas detentoras de ter maior poder para deixar as faculdades de medicina ao encargo das corporações médicas emergentes para que eles mesmos, isto é, as elites políticas e intelectuais, decidissem sobre as características de suas próprias práticas e princípios. A medicina, além de ser considerada pelo lado de sua prática assistencial e sanitária, passou a ser considerada como um saber, fazendo dos hospitais locais do aprendizado médico. O estreitamento normativo cerceou espaço suficiente para que surgissem novas formas de organização administrativa para controlar a atividade dos médicos 
e inserir a educação dos assuntos da saúde nos âmbitos hospitalares urbanos, centralizando a prática e o ensino da medicina institucionalmente.

No final do século XIX a prática médica tinha um espírito cientificista e positivista que a caracterizava de modo geral. Nessa época, a medicina começou a passar por um processo de mudança que foi de uma "medicina individual" para uma "medicina social" (Foucault, 1979) evidenciando os sentidos da saúde pública dos Estados Nacionais, que vinham surgindo em um processo ascendente de consolidação e desenvolvimento nessa época no mundo ocidental. A dualidade é interessante para pensar sobre as características dos extremos do binômio moderno "indivíduo-sociedade", mas a divisão conceitual em si pouco informa sobre o espectro de sobreposições com as quais as instituições estruturantes da máquina estatal se arranjaram nas sociedades modernas. Para Foucault (1979) a ideia de "medicina social” fazia parte do processo de surgimento do Estado Nacional moderno e é por esta razão que recorrer à esse autor possibilita melhor compreensão de como a institucionalização da medicina moderna e de seu ensino se imbricou política e ideologicamente com a consolidação da própria ideia e estrutura dos Estados modernos.

Com base nas reflexões de Foucault $(1963 ; 1979)$ é possível afirmar que a saúde da população nos centros urbanos da Europa foi se tornando questão de segurança pública e a vigilância do Estado sobre os assuntos epidemiológicos das populações tomou forma e adquiriu força como nunca antes na história. Começaram, então, a serem sobrepostos diferentes níveis do alcance da prática médica assistencial provenientes do Estado e das novas formas de administração da saúde pública juntamente com o crescimento do mercado econômico. Os campos de conhecimento sanitário e de saúde dos corpos da população explorados pelas faculdades de medicina passaram, consequentemente, por um processo análogo de padronização das práticas pedagógicas de que Foucault (1963) fala quando narra o processo de nascimento da clínica médica moderna, que se deu conforme lógicas disciplinares biológica e epidemiologicamente voltadas para a classificação da distribuição das doenças, da experiência clínica e hospitalar, do controle do próprio médico, da definição de um estatuto político para a medicina diante das políticas de Estado, gerando efeitos amplos ao controle da produção e circulação dos conhecimentos, práticas e da instituição do hospital enquanto lugar privilegiado do aprendizado médico. 
Na imbricação entre as práticas médicas e o controle do Estado sobre as questões da saúde, no que concerne especificamente ao ensino da medicina no Brasil moderno, é fundamental fazer referência ao Relatório Flexner, elaborado pela Fundação Rockfeller, em 1913, nos Estados Unidos. A Fundação Rockfeller exerceu influência e poderes capazes de internacionalizar valores, imputar determinadas formas de mentalidade e planejar modelos de projetos sociais; ainda mais quando o modelo culturalista norte-americano de vida era vendido e disseminado por vastos espaços do globo a velocidades grandes, vis a vis o já citado estado de bem estar social que servia como modelo de gestão em alguns países europeus. Essa fundação objetivou incentivos às ações educacionais nas áreas da saúde através do provimento e incentivo financeiro e ideológico internacional para instituições estatais ligadas à saúde pública. Boa parte da responsabilidade e divulgação do modus operandi da "medicina moderna" ocidental, isto é, da "medicina científica" ou da "medicina das especialidades disciplinares" e "medicina alopática", pode-se dizer, é fruto das proposições feitas por essa fundação, dadas as intenções internacionalizantes de sua ideologia e divulgação de suas políticas (Almeida Filho, 2010; Palgiosa e Ros, 2008).

O Relatório Flexner, publicado em 1910, foi uma das formas de influência ideológica e política mais significativas e profundas na prática médica moderna e contemporânea no Brasil. Esse relatório foi o resultado de deliberações entre intelectuais médicos e políticos de influência social sobre a criação de uma nova maneira de gerir as escolas de medicina e a própria lógica da prática médica marcando a gênese da medicina moderna das especialidades disciplinares. Não tardou para que a medicina brasileira adotasse o modelo de formação acadêmica semelhante ao modelo norte-americano (Bulcão, El-Kareh, Sayd, 2007). Ademais, no início do século XX, o número de escolas de medicina aumentou significativamente em vários países (Pagliosa e Ros, 2008) e, devido ao aumento de estudos e do desenvolvimento de novas tecnologias médicas que vinham junto com o alargamento escolar das instituições de ensino em medicina, o Relatório Flexner estabeleceu que o ensino da medicina deveria ser centrado no ensino das disciplinas biológicas e em práticas laboratoriais e clínicas técnicas. Era a gênese da chamada "medicina flexneriana" que, no Brasil, começou a ter influência mais forte a partir dos anos 1940 (González e Almeida, 2010).

O modelo norte-americano de medicina, isto é, o modelo das especialidades disciplinares, estabeleceu a divisão disciplinar tradicional nos currículos de medicina em um 
primeiro bloco de atividades mais teóricas de caráter preparatório e um segundo bloco no qual os estudantes observavam e atuavam nos centros hospitalares nos moldes dos hospitais-clínicas, repletos de setores especializados para cada disciplina ou sistema classificatório da biologia humana. Tal divisão disciplinar é uma das fontes da crítica comum de que a medicina moderna é fragmentadora do corpo humano e de seus processos de saúde, doença e tratamento. Entretanto, tal fragmentação faz parte de uma determinada forma escolhida de se ver o mundo, que é implicada no processo de disciplinarização das práticas médicas diante dos processos de formação profissional e de percepção dos processos de saúde-doença-tratamento que fragmentam esses processos e os destilam. Tal fragmentação dos processos da saúde humana não eram colocadas em questão pelos propositores do modelo flexneriano de ensino em medicina e a preocupação dos idealizadores desse modelo visavam mais a otimização dos processos clínicos hospitalares do que uma disposição à enxergar os desdobramentos da maneira fracionada e rígida de se abordar os processos de saúde-doença-tratamento.

Ancorando a discussão sobre o Estado no horizonte do debate da construção da nação brasileira no inicio do século XX, Herchmann, Kropf, Nunes (1996) buscam compreender os diversos grupos e atores envolvidos com a construção de um ideário de nação e progresso através da ciência na passagem do século XIX para o século XX. Os autores reconhecem que houve um período em que o processo de modernização nacional gerou transformações na ordem social através da construção de uma rede institucional calcada nos imperativos positivistas modernos da ideia de Estado, tais como a ideia de "progresso", "nação" e "ciência" (Herchmann, Kropf e Nunes, 1996, 9). Isso lembra as reflexões feitas por Lima e Hochman (2000) acerca do avanço do Estado calcado no movimento sanitarista do início do século XX no Brasil. Eles dizem o seguinte quanto ao contexto de consolidação do Estado brasileiro no início do século XX:

\footnotetext{
Nossa hipótese é que o movimento pelo saneamento teve um papel central e prolongado na reconstrução da identidade nacional a partir da identificação da doença como elemento distintivo da condição de ser brasileiro. Trata-se, em suma, de uma reflexão em torno de um diálogo muitas vezes implícito entre as matrizes da saúde pública e conhecidas teses do pensamento social e político brasileiro; ou melhor, de perceber como uma perspectiva médico-higienista da sociedade brasileira transformase numa questão da cultura e da política, compartilhada por diferentes intelectuais e outros atores sociais. Tal perspectiva guarda forte relação com as matrizes dualistas de reflexão sobre o Brasil, que apontam não apenas para os contrastes, mas para as lacunas, para as ausências. No Brasil, a ciência do início do século XX e, ainda, a ciência social institucionalizada a partir dos anos 30 podem ser consideradas as linguagens, por excelência, do processo de construção nacional. Constitutiva da
} 
matriz dualista, a ciência buscava identificar os sintomas de nossa cultura, submetendo-os ao espelho crítico de um outro civilizado, constituindo-se, enfim, em um instrumento do projeto modernizador que nos garantiria uma almejada sintonia com o progresso. (Lima e Hochman, 2000, 314)

É possível perceber com clareza na elaboração teórica dos autores que o projeto modernizador da nação brasileira veio sendo tramado e construído historicamente com base nas medidas político-sanitaristas do Estado. A saúde no Brasil se tornava sinônimo de matriz social e cultural na consolidação da própria ideia de nação brasileira e de um projeto ideológico e político que se estendia além da prática médica em si.

No tocante ao campo da medicina, num sentido semelhante dado por Lima e Hochman (2000) ao contexto brasileiro, Herchmann, Kropf e Nunes (1996) dizem que a doutrina positivista permitiu que aqueles que eram "especialistas se auto concebessem como responsáveis pela orientação e organização da 'nação', ajustando-se com isso também às demandas de reordenação social que existiam por parte do Estado.” (Herchmann, Kropf e Nunes, 1996, 16). Nas palavras dos autores:

\begin{abstract}
Ao se articular à medicina, no último quartel do século XIX, o Estado republicano decretou o fim da autonomia da família e um incremento no controle social. Cada vez mais, a medicina torna-se responsável pela vida privada dos indivíduos. [...] O objetivo desses médicos, higienistas e sanitaristas era, de forma geral, normatizar, [...] Entretanto, esta normatização proposta pela medicina não sei limitou somente à família. A chamada 'medicalização da sociedade brasileira', identificada por estudiosos do período, sugere-nos uma intervenção social intensa, autoritária e sem fronteiras. [...] As duas principais instituições do país responsáveis pela formação desses intelectuais-cientistas eram a Faculdade de Medicina do Rio de Janeiro e a da Bahia. Enquanto a primeira tinha grande tradição clínica e influencia francesa, a segunda ingressou mais facilmente no campo experimental e tinha como orientação as teses alemãs e italianas. Enquanto a tendência entre os médicos cariocas é combater principalmente as doenças e os 'maus hábitos' cotidianos da população, a tendência entre os médicos baianos [...] era concentrar-se sobre o doente e as características transmissíveis de forma hereditária. (Herchmann, Kropf e Nunes, 1996, 17)
\end{abstract}

Herchmann, Kropf e Nunes (1996) ainda complementam o argumento dizendo que, além das diferenças entre os centros de ensino baiano e carioca, havia resistência e insatisfação da população ao ver as esferas da vida privada invadidas pelas políticas do Estado. As prioridades da ciência e do intelectualismo eram a pauta da polêmica de construção da nação, o autor coloca; e ainda salienta que nas primeiras décadas do século XX, a medicina pública era tutelada pelos poderes do Estado ao mesmo tempo em que se adensavam as redes institucionais estatais ligadas às questões da saúde da população brasileira (Herchmann, Kropf e Nunes, 1996). 
Para dar concretude analítica a essa rede de que Herchmann, Kropf e Nunes falam, uma breve viajem ao passado é valida. Em 1919 foi criado, no Rio de Janeiro, o Departamento Nacional de Saúde Pública (DNSP), entidade institucional de caráter ampliado que tomou a frente das políticas nacionais de modo que os efeitos do Estado nos serviços sanitários do país se solidificaram de forma concisa e ineditamente ampliada no que diz respeito às políticas nacionais de saúde (González e Almeida, 2010). Em relação à formação e educação médicas, graças à urbanização e intensificação dos mercados industriais e corporativos, se multiplicavam os trabalhos práticos voltados para a profissionalização e especialização médicas e as faculdades começaram a modelar seus currículos conforme as intenções da agenda estatal. $\mathrm{Na}$ década de 1920, conforme o mercado de trabalho nacional se ampliava, surgia também a ampliação do mercado de medicina privada no país e as categorias médicas brasileiras organizadas institucionalmente.

Com um ideário de nação que foi sendo construído com base na mentalidade positivista que trazia a ideia de progresso para o campo das políticas voltadas para a prática médicosanitária, as especializações eram novidade no mercado de trabalho médico, mas ainda assim, a especialização dependia da uma formação generalista, esta que comporia um princípio da formação em medicina no Brasil, a qual atenderia aos propósitos do projeto de nação voltado à ideologia do progresso e ao desenvolvimento industrial e científico no início do século XX.

A ascendência do Estado populista no Brasil e a simultânea industrialização e urbanização que seguiu curso em diversas regiões do país, na década de 1930 criou-se o Ministério da Educação e Saúde Pública (MESP), promovendo campanhas sanitárias voltadas à questões de higiene pública com os vieses da medicina preventiva (Bulcão, El-Kareh, Sayd, 2007). Importante notar a proximidade original dos elos de interdependência no tocante ao fato de que o MESP conjugava em uma única instância governamental as grandes cearas centrais nesta pesquisa, a dizer, da educação e saúde. Essas duas áreas da gestão pública no Brasil vem como vetores conjugados de um mesmo processo de consolidação de um projeto de nação no qual a educação e a saúde começavam a se tornar deveres do Estado, o que evidencia a imbricação nacional próxima entre o campo da saúde e o campo da educação. Atualmente esse ministério é separado entre o Ministério da Saúde e o da Educação, contudo, a característica histórica de suas origens em comum evidencia a imbricação institucional e política dessas 
instâncias diante do projeto de nação e de gestão pública da medicina e seu ensino que vinham sendo desenvolvidas no Brasil nas primeiras décadas do século XX.

\begin{abstract}
Em outras palavras, ao mesmo tempo em que realça o potencial das 'intervenções', que enfatiza a importância da prevenção por parte do médico e do cientista, evidentemente acompanhada da atuação provedora do Estado - numa clara referência à doutrina positivista ('prever para prover') -, trata também da 'degeneração' ou 'atraso' do país como fruto de um determinismo geoclimático. Tem, assim, a natureza como centro dos acontecimentos, isto é, sugere um tipo ideal de construção discursiva que caracterizou o naturalismo estético no meio intelectual do final do século XIX e início do século XX. Ou seja, ao mesmo tempo que estes intelectuais-cientistas se diziam capazes de 'recuperar' o país, afirmavam também de antemão que, para a realização dessa tarefa 'colossal' seriam necessários tempo e, principalmente, apoio do Estado. (Herchmann, Kropf e Nunes, 1996, 34)
\end{abstract}

Herchmann, Kropf e Nunes (1996) revelam de forma clara como que as camadas médicas recebiam e tomavam para si a tarefa de romper com o "atraso" e "recuperar" o país tão logo o peso político desta responsabilidade tomou acento. A assistência médica, que vinha sendo representada por um sistema público esparso e descentralizado, passou a ser calçada numa ideia de integração nacional que formava uma rede de subordinações dentro do Estado, institucionalizando as atividades médicas junto aos ideais do desenvolvimento cientifico e progresso da nação através do provimento da saúde nacional.

Machado et. al. (1978), também tratando do caso brasileiro, diz que devido aos avanços do Estado sobre a sociedade a medicina precisou ser organizada como um poder político dentro do campo de valores, colocando a própria medicina como condição para o firmamento dos poderes liberais e ideários nacionais. O autor diz que a medicina social no Brasil no começo do século XX era um projeto político com poder suficiente nos espaços institucionais da sociedade brasileira para intervir no sistema de saúde do país como um todo.

O objetivo final da medicina social é, de maneiras diversas, formar ou reformar física
e moralmente o cidadão. Por um lado o homem é um todo físico-moral e não a junção
de dois princípios de natureza independente. As disposições morais do homem são
condensadas por circunstancias físicas. As disposições físicas se alteram por
circunstâncias morais desfavoráveis. O conhecimento médico naturaliza a moral. [...]
Por outro lado, e consequentemente, a medicina é conhecimento globalizante do
homem como ser natural e social, como indivíduo e população. À consideração da
cidade como macro-social corresponde a tematização micro-social da instituição
também como um corpo que produz cidadãos, isto é, homens urbanizados, integrados
à cidade, ordenados em relação ao todo urbano. O homem não é apenas organismo
vivo, ele integra um organismo social. A medicina visa a civilizar, isto é, a urbanizar
o homem. (Machado et. al., 1978, 280-1)

As camadas intelectuais médicas e elites políticas do governo brasileiro passaram a instituir a criação de "hospitais-clínicas" onde se concentrassem num espaço só a diversidade 
ampla de especialidades médicas e logísticas que possibilitariam que as atividades do ensino acadêmico acontecessem de maneira a dar conta da diversidade de especialidades médicas típicas dos modelos médicos europeus, com foco mais preventivo e social, e norte-americano, mais científico, frente o estudo e criação de políticas sociais voltadas para a saúde.

O Estado adquiriu caráter de transversalidade ao abrir campos de negociação com as várias partes e setores que compunham as estruturas públicas que por ele eram geridas. $\mathrm{O}$ hospital e a clínica médica no Brasil como órgãos centralizadores da prática médica formaram expressões do avanço do Estado sobre as questões do ensino médico como um dos condutores das ideologias integradoras versadas pelas políticas estado e não demorou muito para que os "hospitais-clínicas" se tornassem também "hospitais escola".

Retomo as reflexões de Foucault (1963) para destacar o nascimento dos hospitais como instituições de ensino e controle das doenças que fundam o modelo "hospitalocêntrico" e institucionalizado de ensino em medicina, controlado pelo Estado de acordo com o projeto de integração nacional e ideário de progresso que vinham casados com o espírito científico e político que imputava o caráter da atividade médica pública e social e o controle sobre seu ensino no Brasil.

\footnotetext{
[A medicina] tornou-se o órgão oficial de uma consciência coletiva dos fenômenos patológicos; consciência que se manifesta, no nível da experiência como no nível do saber, tanto de forma cosmopolita quanto no espaço da nação. [...] Novo estilo de totalização. [...] O que constitui agora a unidade do olhar médico não é o círculo do saber em que ele se completa, mas esta totalização aberta, infinita, móvel, sem cessar, deslocada e enriquecida pelo tempo, que ele percorre sem nunca poder detê-lo [...] Mas seu suporte não é a percepção do doente em sua singularidade, é uma consciência coletiva de todas as informações que se cruzam, crescendo em uma ramagem complexa e sempre abundante, ampliada finalmente até as dimensões de uma história, de uma geografia, de um Estado. (Foucault, 1963, 29-31)
}

No Brasil, a configuração de uma dialética dos processos de desenvolvimento nacional entre políticas de ensino em medicina com base numa excelência técnica projetada nos currículos de medicina no país (Hora et. al., 2013) por um lado e, por outro, a instituição médica se formava como um polo agregador de poder político que carregava uma parte considerável do projeto da nação brasileira, traz a imbricação dos projetos de políticas públicas voltados para a formação de profissionais médicos para atuarem nos sistemas públicos do próprio Estado. $\mathrm{O}$ aumento demográfico e a consolidação da república intensificou a oferta de vagas no mercado de trabalho e levou ao aumento da pressão sobre as vagas existentes nas faculdades de medicina. 
Por sua vez, as faculdades, aliadas aos hospitais-clínicas, se constituíam com vigor, levando a cabo a formação intensificada de profissionais voltados à medicina privada e especializada (Hora et. al., 2013). Ao mesmo tempo em que surgia a figura de uma medicina mais competente tecnicamente, o fetiche da política de saúde brasileira pelo progresso e pela integração nacional com base na prática científica e médica foi uma categoria ideológica que movimentou a saúde como dever e função do Estado.

Já na época da ditadura no Brasil, isto é, por volta dos anos 1950 e 1970, segundo a síntese feita por Pereira e Almeida (2005), o regime militar incrementou ênfase na ideia de que um suprimento da quantidade numérica de médicos era sinônimo de progresso e desenvolvimento da nação brasileira, tendo também, no que tange ao ensino em medicina, incentivado o predomínio e disseminação dos modelos mais tradicionais de educação pelas faculdades brasileiras. Segundo Guerreiro e Branco (2011), na década de 1960 o foco da política nacional voltada à saúde pública era calcada num modelo autoritário, por parte do governo, técnico pelo incentivo à ciência e tecnologia como vetores de um país econômica e administrativamente mais avançado, tecnológico e capitalista pelo incentivo ao adensamento industrial dos mercados brasileiros através de políticas nacionalistas. A ditatura colocou em relação íntima a ciência, a tecnologia e a educação nas pesquisas ligadas ao desenvolvimento industrial e tecnológico de modo que o Estado brasileiro na época avançou ao controle das práticas no campo da ciência médica, a qual passou a servir ao Estado como instrumento modernizador e propulsor da ideia de uma nação bem gerida com foco no desenvolvimento científico e tecnológico. Isso se refletiu nos mecanismos de controle avassalador de circulação do conhecimento e na implementação de modelos educacionais tradicionais que foram promovidos pelo Estado brasileiro na época da ditadura (Guerreiro e Branco, 2011).

\section{DA VIRADA DEMOCRÁTICA AO SISTEMA ÚNICO DE SAÚDE}

Com a virada democrática no Brasil, a questão da saúde começou a ser tratada como “direito de todos e dever do Estado" (CF88, Art. 196). O Estado passou a prover a saúde pública e se ancorou na ideia de democracia que as noções de equidade e universalidade dos direitos que traziam. Nas décadas de 1970 e 1980 houve um aumento do número de faculdades de medicina pelo país e a ampliação de projetos institucionais que emergiam tanto das categorias 
políticas quanto médicas da época. Dentre esses projetos institucionais, surgiram focos alternativos de construção dos currículos médicos numa proposta contrária à crescente tecnologização e cientificismo que caracterizou o período militar (Borba e Neto, 2008; Siqueira Batista e Siqueira Batista, 2009). O surgimento de focos alternativos ao modelo da medicina disciplinar tradicional apareceram dentro desse processo de desenvolvimento histórico do Estado brasileiro, mas foram muitas vezes suprimidos e dificultados em face dos processos políticos e burocráticos para sua implementação.

No que diz respeito à saúde pública no Brasil, a década de 1980 marcou um processo amplo de reorganização e reordenação do sistema público de saúde nacional com o movimento da Reforma Sanitária, cujo Sistema Único de Saúde (SUS) é fruto central, além da promulgação da Constituição Federal de 1988 (CF88), documento vultuoso à consolidação do Estado nacional brasileiro e conotada como "Constituição Cidadã". O ambiente político no final da década de 1980 propiciou incentivo à iniciativas voltadas ao amadurecimento de um novo projeto de Estado e de nação que veio a ser concretizado simbolicamente pela reforma constituinte e pelo ideário de um projeto nacional integrado e democrático nos vários níveis de seus setores públicos, inclusive no setor da saúde.

A VIII Conferência Nacional de Saúde de 1986 foi marco crucial para a concretização do Sistema Único de Saúde (SUS). O SUS veio trazer uma ampla divisão das responsabilidades das políticas colocando a força de gestão e político-administrativa no âmbito dos municípios à exemplo da IX Conferência de Saúde de 1992, a qual se chamou "Munincipalização é o Caminho". Esse caráter descentralizador da gestão pública deu início ao desenvolvimento da ideia de gestão democrática da saúde, nos moldes que o projeto de nação brasileira outorgava desde o final dos anos 1980 e colocava os municípios como gestores de sistema nacional, universal, igualitário, equânime, integral e que pela natureza de sua gestão é em si participativo, isto é, democrático. Em certo sentido é o cidadão nos municípios que se tornam os responsáveis pela gestão desse sistema primeiro pela divisão de responsabilidades na gestão e segundo pelo seu caráter hierarquizado que coloca força política e administrativa no âmbito local e municipal.

O Sistema Único de Saúde (SUS) veio instituir uma determinada noção de saúde assistencial calcada em valores de "igualdade" e "equidade", os quais evocam o sentido da diferença e da democratização da saúde, as quais juntas remetem ao valor de inclusão social cidadã; além de trazer os valores de "integralidade" e "universalidade", os quais imprimem a 
noção de que o serviço de saúde prestado pelo Estado é total no que diz respeito à abordagem dos processos de saúde-doença-tratamento e de inclusão social. Decorre disso que a forma de gestão da saúde brasileira mudou partir da consolidação do SUS e a noção de saúde que se tinha também mudou, isto é, voltou seu foco para a atenção básica nos vários níveis da assistência em saúde no Brasil. O SUS, portanto, surge nesse contexto como uma organização administrativa da saúde pública brasileira e também como vetor importante de valores expressados pela natureza democrática que a gestão do Estado desenvolveu e pelo caráter assistencial básico, que constitui seu foco maior atualmente.

Mesmo antes de a Constituição de 1988 vir a ser promulgada e marcar a virada democrática no que concerne às políticas de gestão do Estado, algumas políticas públicas voltadas à formação médica no país com modelos integradores de um sistema único nacional de assistência de saúde já vinham sendo desenvolvidas e executadas nos prelúdios da virada democrática. No âmbito do Ministério da Saúde do Brasil (MS) foi criado em 1981 o Programa de Integração Docente-Assistencial (IDA), que visava a formação de profissionais da saúde dentro dos próprios serviços médicos do país (Dias, Lima, Teixeira, 2013). O Programa de Integração Docente-Assistencial (IDA) incentivou a criação de relações cooperativas entre diversas instituições envolvidas com a saúde pública do país através de uma rede que, pela primeira vez na história da gestão da saúde pública do Brasil, passava a agir de modo ampliado sobre todo o território da nação. Tempos depois, fazendo parte do mesmo ensejo de políticas educacionais vinculadas à saúde, foi criada a "Uma Nova Iniciativa" (UNI), projeto governamental de caráter nacional que veio a redimensionar o Programa de Integração Docente-Assistencial (IDA), que passou a contar com ações formativas de caráter multiprofissional e multi-institucional integrado às bases de assistências locais num sistema mais amplo e em rede, que por sua própria natureza transcendia o teor localista e segmentado que o Programa de Integração Docente-Assistencial (IDA) adquirira em seus primeiros anos de funcionamento (Dias, Lima, Teixeira, 2013). Entretanto, essas políticas de educação em saúde se concentraram com maior ênfase na relação docente-assistência, que consistia numa aproximação maior do ensino médico com o serviço de saúde, o que gerou uma série de questionamentos por parte da elite política governante quanto ao alcance e sucesso desse projeto enquanto política pública que desse ênfase a atenção primária e preventiva, ideais práticos das política de saúde que vinham sendo divulgados e promovidos desde 1978, com a Declaração de Alma-Ata pela Conferência Internacional sobre Cuidados Primários de Saúde (Gonzáles e 
Almeida, 2010; Chaves, 1994) que defendia a disseminação internacional de implantação de sistemas de saúde públicos que tivessem a atenção primária e a medicina preventiva como forma de organização cardeal. Percebe-se que os programas Programa de Integração DocenteAssistencial (IDA) e Uma Nova Iniciativa (UNI) podem ser grandes exemplos de movimentos nacionais em prol de transformações na formação de profissionais na área da saúde e buscaram resolver problemas gerados dentro da gestão do próprio sistema público de saúde (Gonzáles e Almeida, 2010).

A Constituição Federal de 1988 foi um dos marcos mais importantes para a democratização do Brasil e institui a saúde com um dever do Estado e a participação social na gestão democrática da máquina pública brasileira desde então. Depois que a Constituição de 1988 foi promulgada, houve incremento das políticas públicas voltadas para a educação em saúde. O grande trunfo dos projetos de políticas públicas de saúde durante os anos 1990 foram a preparação de um campo no qual as articulações entre a educação e a saúde puderam ser criadas com maior vigor. No mesmo fluxo de programas e com os objetivos do projeto Programa de Integração Docente-Assistencial (IDA) e Uma Nova Iniciativa (UNI) sendo amadurecidos, em 1990 foi instituída pelo governo federal a "Rede Unida", que obteve ajuda de diversos polos de formação e das estruturas municipais para a montagem e configuração de uma ampla rede nacional de implantação de programas de ensino em medicina nas faculdades públicas de medicina pelo Brasil (Borba e Neto, 2008). O Estado brasileiro criou uma verdadeira rede nacional de implementação de políticas educacionais voltadas à educação em saúde que obteve resultados satisfatórios do ponto de vista de seu caráter de integração nacional e de seu projeto de nação na gestão democrática da saúde mas, entretanto, esta rede ainda não estava concretizada de maneira inteiramente integrada. No que diz respeito ao adensamento e desenvolvimento da atenção primária e aos incentivos às práticas médicas preventivas e sanitaristas, as iniciativas das camadas intelectuais e políticas com vistas à atenção básica deixaram a desejar uma vez que o mercado médico continuou a ser movido por tendências voltadas à especialização científica (Hora et. al., 2013) e à disciplinarização das práticas médicas conforme os modelos tradicionais de ensino em medicina que foram incentivados durante a ditadura militar e perpetuaram-se nas várias faculdades de medicina do Brasil.

Percebe-se que os maiores problemas do funcionamento dessas políticas públicas amplas de nível nacional era a inadequação e fragmentação dos projetos políticos que visavam 
“consertar" a saúde pública brasileira, mas sem se desvencilhar dos modelos pedagógicos voltados ao mercado especializado da medicina privada. A separação disciplinar e compartimentalizada dos modelos pedagógicos importados e a presença cada vez mais forte de profissionais especializados no mercado de trabalho médico dividiam o mercado da medicina entre um campo técnico e especializado dominado pela medicina privada, e um outro campo da medicina pública, politicamente idealizado com base no desenvolvimento da atenção primária como trampolim ideal para a consolidação da ideia de nação brasileira. Isso vinha de encontro aos ideais do movimento da Reforma Sanitária nos anos 1980, o qual tinha propostas democráticas de gestão e de implementação de um determinado tipo de serviço de saúde e assistência nacional na qual a necessidade de uma reforma do ensino da medicina era posta como imperativo à própria atualização e revigoramento de um projeto de nação mais amplo com os valores de crescimento, desenvolvimento e democracia.

Segundo González e Almeida (2010), o processo de implementação destas políticas de abrangência nacional era guiado por quatro vetores principais, a dizer: a "formação"; a "assistência", a "gestão" e a "participação". Todos os quatro vetores também diziam respeito ao projeto de nação mais inclusivo e democrático que vinha sendo construído e que teve como um de seus pilares a consolidação do próprio Sistema Único de Saúde (SUS) no Brasil. O primeiro vetor desse projeto de nação, que se calçava no desenvolvimento de um sistema de saúde integrado nacionalmente por todo o território do Estado, tinha como foco a educação, a saúde, e o gerenciamento só sistema público de saúde prevendo a participação da sociedade nas arenas públicas de poder ao buscar, ao menos como princípio, democratizar os processos. Surgia aí um novo ímpeto por mudança na situação da assistência e acesso à saúde no Brasil que fazia parte do projeto político nacional e histórico, que visava um desenvolvimento maior em aspectos relacionados ao "suprimento de recursos humanos" com vistas ao "desenvolvimento do sistema de saúde" brasileiro.

Com a força da categoria médica insuflada politicamente pelas políticas do Estado em menção aos programas políticos voltados para o ensino em saúde que foram mencionados até aqui, como o Programa de Integração Docente-Assistencial (IDA) e Uma Nova Iniciativa (UNI), e tendo em vista a elitização de suas práticas técnicas, a Associação Brasileira de Ensino Médico (ABEM) juntamente com o Conselho Federal de Medicina (CFM), junto de outras instituições que também fizeram parte das arenas que uniam intelectuais e políticos em torno 
da criação das políticas públicas voltadas para a educação em medicina, introduziu-se a avaliação e proposição de incentivos à prováveis mudanças curriculares que idealmente deveriam seguir nacionalmente (Dias, Lima, Teixeira, 2013) e criou-se a Comissão Interinstitucional Nacional de Avaliação das Escolas Médicas (CINAEM). Essa comissão fez um levantamento do perfil das escolas médicas brasileiras e também fez pesquisas com foco na docência vislumbrando novas possibilidades pedagógicas à formação médica no Brasil. Foi gerado um relatório que mostrava a inadequação do modelo flexneriano de ensino em medicina junto à confirmação da crescente especialização do mercado médico (Siqueira-Batista, 2013). A comissão buscou desenvolver e colocar em prática, em conjunto com as camadas executivas do poder estatal, ações de transformação do ensino médico no Brasil com a intenção de corresponder e adequar com mais eficiência os currículos de medicina às necessidades da população e saúde brasileiras (González e Almeida, 2010). Fica clara a presença candente da promoção feita pelas políticas do Estado brasileiro para a integração entre os serviços de saúde e as instituições de ensino profissional e superior em medicina em escala nacional.

No Art. 14 da Lei 8.080 de 1990, lei que institui o Sistema Único de Saúde (SUS), o texto ampara e incentiva a criação de comissões institucionais que proponham

[...] meios estratégicos para a formação e educação continuada dos recursos humanos do Sistema Único de Saúde (SUS), na esfera que corresponde, assim como em relação à pesquisa e à cooperação técnica entre essas instituições. (Brasil, 1990)

Essas instituições a que a Lei 8.080 de 1990 se refere são aquelas de caráter público que estejam voltadas para a formação de recursos humanos para trabalharem no novo sistema público de saúde nacional. Essa política de formação de recursos humanos no serviço público de saúde também explicita que o "SUS constitui campo de prática para ensino e pesquisa, mediante normas específicas, elaboradas conjuntamente com o sistema educacional" (Brasil, 1990). As políticas públicas de saúde respondiam à totalidade da população e à busca dos valores individuais modernos e democráticos de "igualdade", "equidade" e "integralidade", presentes como vetores políticos ao se estenderem aos diversos aspectos da sociedade e das questões da gestão democrática da saúde pública, inclusive a educação e formação profissional. Hora et. al. (2013) diz que o SUS atingiu o nível de "maior mercado empregador" segundo muitos artigos publicados sobre os impactos de sua criação e criou um espaço político denso para a implementação de políticas que visam a construção de um novo tipo de profissional da saúde e de um sistema de assistência em saúde. Isso fez com que o próprio SUS se tornasse um 
campo suscetível à disputas ideológicas e de conflito de forças e poderes institucionais entre atores sociais que defendem uma medicina intramuros, isto é, focada nos modelos propostos pela medicina flexneriana e especializada, e aqueles atores sociais que se manifestavam em prol de um projeto assistencial nacional através do sistema público de saúde focado na atenção básica através de modelos alternativos de formação.

Depois do Programa de Integração Docente-Assistencial (IDA) e Uma Nova Iniciativa (UNI) nos anos 1980, da Rede Unida nos anos 1990 e das resoluções produzidas pela Comissão Interinstitucional Nacional de Avaliação das Escolas Médicas (CINAEM) nos anos 2000, uma nova série de programas nacionais foram criados com foco na formação de profissionais dentro do SUS. Por volta dos anos 2000, foi implementado o Programa Nacional de Incentivo a Mudanças Curriculares de Medicina (PROMED), que buscou adequar a formação médica no país aos preceitos vigentes no SUS de forma mais direta e integrada. O Programa Nacional de Incentivo a Mudanças Curriculares de Medicina (PROMED) visou a criação e o fortalecimento de uma rede nacional de saúde pública através de políticas de gestão descentralizadoras e ao mesmo tempo não-fragmentadas (Hora et. al., 2013). A solicitação destes preceitos através desses projetos firmou as molduras de um política de formação e desenvolvimento para o SUS e marcou a definição de uma série de projetos que levou a cabo o estabelecimento do campo de saberes e de práticas da educação profissional em saúde no rol dos quesitos para a efetivação da integração nacional através dos programas de saúde providos pelo Estado.

É preciso ressaltar que as diretrizes curriculares para os cursos de graduação em medicina foram homologadas pelo Conselho Nacional de Educação (CNE) com vistas à promoção de um novo tipo de profissionalismo médico que viesse em contraponto ao especialismo disciplinar que vinha se fortalecendo desde a segunda metade do século XX (Dias, Lima, Teixeira, 2013). A situação das politicas públicas voltadas para a educação em medicina no Brasil culminou no estreitamento maior das interconexões entre as instituições públicas de formação educacional em saúde do país e o sistema público de assistência de saúde. Destacamse três projetos importantes que marcam o caráter das políticas de educação em saúde neste período, isto é, na passagem do século XX para o século XXI. Em 2004 foram instituídos o "Ver-SUS", que tinha como objetivo a realização de vivências e estágios na realidade do sistema público de saúde; o "Aprender-SUS", que teve foco mais voltado para a "integralidade da atenção" deslocando-se sobre o eixo de mudança na formação profissional; e o "Ensina- 
SUS”, que tinha como objetivo o incentivo para pesquisas inovadoras na formação médica (Dias, Lima, Teixeira, 2013). Em 2005 foi a vez do Programa Nacional de Reorientação da Formação Profissional em Saúde (PRÓ-SAÚDE), através do qual buscou-se uma maior aproximação entre as políticas estatais voltadas para a interação entre a educação e a saúde no sistema público. Nos anos seguintes, por volta de 2007, foram criadas pelo governo federal mais duas grandes políticas voltadas para a formação de profissionais com foco a realidade do sistema de saúde brasileiro. A dizer, estes foram o Programa Nacional de Reorientação da Formação Profissional em Saúde (PRÓ-SAÚDE) e o Programa de Educação pelo Trabalho para a Saúde (PET-SAÚDE), para promover uma certa indissociabilidade entre ensino em saúde e assistência em saúde através de metodologias de aprendizagem ativas calcadas na interdisciplinaridade de incentivo à pesquisas voltadas à atenção primária (Dias, Lima, Teixeira, 2013) em consonância com as políticas voltadas à atenção básica que vieram caracterizar os serviços de saúde no início do século XXI no Brasil.

A noção de nação que se almejava através da implementação projetos e políticas públicas se expressava em diversos níveis. Visando uma integração democrática através de mecanismos de participação social nas políticas públicas, o escopo desses projetos vinha atrelado à uma ideia de futuro e de integração nacional que objetiva o crescimento do país em consonância com o bojo maior da ideia de um "Brasil sem miséria" e da ideia de "inclusão social" e "gestão democrática" de um Estado que valoriza a pluralidade e a tolerância da diversidade de valores e cidadãos que dele fazem parte. A ideologia concatenada à ideia de integração nacional em vários níveis abastecem a consolidação da própria ideia de um Estado brasileiro mais democrático e provedor dos direitos e realização de seus deveres constituintes.

No campo das políticas públicas voltadas para a educação em medicina, o contexto de construção idealmente descentralizado da saúde exprimia a construção social da nação através da integração da saúde nacional através de uma rede que compõe um sistema unificado que ao mesmo tempo valoriza a produção do conhecimento (ensino) através da prática (serviço); e dá importância à novos modelos de ensino e aprendizagem que valorizam o papel do estudante no processo de formação profissional (Siqueira Batista e Siqueira Batista, 2009; Garbi Novaes et. al. 2009). As ações em torno da gestão do trabalho e principalmente da educação através da valorização do vínculo ensino-serviço seguem os princípios de "humanização", “integralidade", “igualdade”, “equidade” e "universalidade” (Brasil, 1990), foram instituídos 
pelo SUS como princípios ideológicos básicos ao seu funcionamento. Os mecanismos institucionais de cooperação técnica entre os serviços públicos em prol da superação do modelo de formação especialista e hospitalocêntrico com vistas a inserção de aspectos ligados à realidade sociocultural das populações nos processos formativos fornecem um programa político básico que se expressa na consolidação de um sistema público de saúde emblemático de um projeto de nação mais democrático administrativamente e inclusivo ideologicamente.

A interação entre ensino e serviço carrega em si responsabilidades não apenas de gestão, mas de política e de ideologia que ainda está buscando a superação de certas tensões e das desconfianças. Implicar em um mesmo processo institucional aquilo que diz respeito ao Sistema Único de Saúde (SUS) uma estrutura complexa de gestão e administração pública quanto veículo de uma ideologia democrática e assistencial-comunitária profunda no que diz respeito à formação profissional do "médico total", profissional preparado para olhar todos os aspectos da saúde "bio-psico-social" das pessoas e melhor conhecedor da atenção básica, mote da política pública de saúde hoje em dia, é criar um processo de transformação profunda repleto de tensões e de desconfianças por parte dos diversos atores institucionais e políticos envolvidos.

A cronologia dos programas e projetos voltados para a consolidação e aprimoramento do Sistema Único de Saúde (SUS) mostra que, apesar de muitas ações terem sido feitas no âmbito das políticas de saúde e da integração entre ensino e serviço de saúde no âmbito da gestão pública, não há consenso em torno da gestão desses projetos institucionais que integram essas duas esferas, isto é, ensino e serviço. Muitas ações do Estado foram feitas ao longo de mais de quase 30 anos desde que o SUS começou a fazer a interface entre educação e assistência e permanecem os conflitos e disputas de forças. As tensões em torno da gestão política e democrática da saúde também ainda existem e isso mostra a dificuldade de se colocar dentro de um mesmo processo atores políticos e institucionais que desconfiam entre si e que não conseguiram até hoje atingir um patamar de confiança mútua diante de projetos públicos voltados para a saúde, principalmente no que diz respeito à projetos inovadores de ensino e formação profissional em saúde.

A perspectiva analítica apresentada neste capítulo tem como função expor a interface análoga ao processo de construção do Sistema Único de Saúde (SUS) no Brasil e à construção de um ideário de nação e de Estado unificados em torno de um de seus pilares mais fundamentais, a saúde. A consolidação de um sistema nacional unificado de assistência em 
saúde integrado à égide do Estado brasileiro marca a evolução do desenvolvimento de projetos voltados para a formação de profissionais de saúde na interface das estruturas assistenciais construídas para o próprio SUS, configurando a interface entre "formação" e "serviço" em saúde tanto em âmbitos formativos quanto no que diz respeito à gestão e administração da saúde nacional.

O objetivo no capítulo seguinte é apontar, numa perspectiva histórica mais localizada, a imbricação e idiossincrasias do Estado na idealização e execução de políticas públicas voltadas para a educação e prática médicas no que diz respeito à criação da Escola Superior de Ciências da Saúde (ESCS) no contexto local do Distrito Federal e preparar um mapa interinstitucional dos atores políticos e intelectuais envolvidos nos caminhos da política e do poder em torno do projeto de transformação da ESCS na projetada Universidade de Ciências da Saúde do Distrito Federal (UNISUS). 


\section{CAPÍTULO 2}

\section{A "DISTRITAL DE MEDICINA DE BRASÍLIA"}

No capítulo anterior foi traçado um breve histórico da série de políticas públicas voltadas para a criação de uma rede nacional de assistência de saúde no Brasil e viu-se que a construção do Sistema Único de Saúde (SUS) fez parte de um processo repleto de transformações em vários níveis da vida social e constitui um dos pilares ideológicos da ideia de Estado democrático brasileiro. Na medida com que as conjunturas políticas foram mudando com o passar do tempo, a saúde brasileira foi se tornando mote ideológico das políticas e a democratização dos processos de gestão é algo inexorável aos processos de transformação. A partir dessa ótica, este capítulo se volta ao passado e ao plano histórico local do processo de implantação da Escola Superior de Ciências da Saúde (ESCS) no Distrito Federal.

Neste capítulo adota-se uma perspectiva analítica que vincula uma série de documentos oficiais e institucionais com registros de falas de estudantes, professores e servidores da Fundação de Ensino e Pesquisa em Ciências da Saúde (FEPECS) e da Escola Superior de Ciências da Saúde (ESCS) que registrei no diário de campo. Quanto ao material para subsidiar a análise documental, acessei uma parcela significativa dos arquivos históricos dessas instituições junto à biblioteca da instituição. Consultei um dossiê de aproximadamente 550 páginas, o qual fora publicado em 2002 pela própria FEPECS e intitulado: "Criação da Fundação de Ensino e Pesquisa em Ciências da Saúde e do Curso de Medicina da Secretaria de Estado de Saúde do Distrito Federal”, com um DVD que trazia um vídeo promocional de 15 minutos sobre a FEPECS, o qual o pessoal da biblioteca disse fora apresentado na ocasião da inauguração da instituição em setembro de 2001.

O dossiê sobre a criação da Fundação de Ensino e Pesquisa em Ciências da Saúde (FEPECS) traz uma série bastante ampla de documentos oficiais produzidos por vários órgãos públicos: trinta e duas atas de reuniões do grupo de trabalho responsável pela implantação da instituição; o projeto político-pedagógico; o regimento interno e o estatuto; organogramas; registros de eventos; e várias reportagens de diversos jornais impressos e digitais locais, cronologicamente dispostas e datadas uma a uma. O dossiê foi publicado pela própria FEPECS 
no ano que se seguiu à inauguração e foi organizado por Adelaie Côrte, bibliotecária e gerente de documentação científica instituição à época, conforme consta na ficha técnica do documento; e a apresentação inicial do dossiê, escrita por Rosângela Watanabe, primeira diretora executiva da FEPECS, traz "o propósito de preservar, para as gerações futuras a história da criação [...] contendo a documentação que reflete importante momento da Secretaria de Saúde" (FEPECS, 2002, 1). Este dossiê, portanto, é importante por seu valor histórico de arquivamento e preservação documental de um processo institucional interno e pela riqueza de dados que traz sobre os processos institucionais do passado.

Além desses documentos dispostos no dossiê da FEPECS, compilei por conta própria mais outros três dossiês ${ }^{1}$ com documentos referentes às outras instituições mais diretamente relacionadas à pesquisa, a dizer: a Escola Superior de Ciências da Saúde (ESCS); a Escola Técnica de Saúde de Brasília (ETESB); e à Universidade de Ciências da Saúde do Distrito Federal (UNISUS). Esta última em si não é uma instituição, é um projeto sobre o qual já se tem muito material já publicado. Tive que fazer escolhas diante do volume de material acumulado durante a análise dos dossiês, os quais, ao todo, somaram cerca de 900 páginas tanto em documentos físicos quanto digitais. Não caberia nesta dissertação uma análise exaustiva de cada um desses documentos e por isso detive-me aqui apenas numa parcela desse total dos documentos nos dossiês, ainda que a visão geral en pasant de todos eles em conjunto tenha ajudado em alguns pontos das reflexões na pesquisa.

Na visão de Celso Castro (2008) é importante ter em mente que a construção e a montagem de um conjunto de documentos sobre uma instituição implicam em processos seletivos de modo com que a compilação de documentos sobre uma instituição resulta

\footnotetext{
${ }^{1}$ A título de apresentação, o dossiê da Escola Superior de Ciências da Saúde (ESCS) trazia: o regimento interno da escola; o manual do estudante do curso de medicina; a estrutura curricular do curso de medicina, o calendário acadêmico do ano de 2013, período no qual realizou-se a pesquisa de campo; o regulamento dos estágios e módulos eletivos; o manual de avaliação do curso de medicina. O dossiê sobre a Escola Técnica de Saúde de Brasília (ETESB) trazia: o histórico e o organograma da instituição; um parecer ( N $^{\circ}$ 220/2002-CEDF) do Conselho de Educação do Distrito Federal referente à autorização de funcionamento dos cursos oferecidos; o regimento escolar; e o manual do aluno da escola técnica. O dossiê sobre a Universidade de Ciências da Saúde do Distrito Federal (UNISUS) trazia: 25 atas de reuniões dos conselhos deliberativo e de gestão da FEPECS, a transcrição de uma entrevista feita pelos estudantes por volta com o assessor de projetos especiais da FEPECS; 4 versões diferentes das minutas do projeto de lei que visa a alteração da Lei $n^{\circ} 2.676$, lei que cria a FEPECS; 2 textos com as justificativas de criação da universidade; 7 reportagens jornalísticas publicadas ao longo de 2013; e uma pequena série de publicações feitas no jornal "O Atestado", organizado pelos estudantes da ESCS.
} 
diretamente da ação de sujeitos que definiram certos materiais em detrimento de outros. Segue disso que os dossiês aos quais recorri durante a pesquisa podem ser considerados como "série[s] de concepções de valor, memória e passado" (Castro, 2008, 29) que os levam a ser preservados, ainda, contem em si o resíduo "resultante de um conjunto de intencionalidades" (Ibid., 35) que refletem quem o produziu, o organizou, o guardou e de quem permitiu sua consulta.

No caso institucional abordado nesta pesquisa, as intencionalidades que esses documentos trazem são a fixação e legitimação de um discurso histórico monumental em que a Secretaria de Estado de Saúde do Distrito Federal (SES-DF), órgão do Estado, se autoproclama como responsável pela mudança nos modelos de formação médica num determinado contexto local. A intenção foi olhar para estes documentos através não apenas da ótica factual da oficialidade de sua natureza, mas também de suas características como mote ideológico dentro dos processos histórico-institucionais. Fica evidente a partir dessa perspectiva em relação aos arquivos, a existência da relevância etnográfica dos dossiês e da importância que eles tem ao informar sobre as vicissitudes dos processos que registram e sobre a memória política que neles permanece presente.

Segundo Mary Douglas (1986), no que diz respeito ao que ela chama de "autocontemplação narcisista" da memória das instituições e que carrega consigo a responsabilidade de construção de algo grandioso ou que coloca um grande número de indivíduos sob a égide de uma instituição social maior, existe de fato um direcionamento da memória social guiado pelos próprios sujeitos dirigentes e membros de uma instituição que escolhem determinados fatos do passado em detrimento de outros, os quais são mais compatíveis com o ideal que a própria instituição busca imprimir nas esferas sociais e gerações futuras. Através dessa fixação temporal de processos sociais e políticos através de documentos os quais, quando escolhidos para fazerem parte do rol dos fatos institucionais compilados nos dossiês, são eternizados e logo passam a motivar determinadas configurações ideológicas que regem processos políticos e organizacionais intrínsecos ao desenvolvimento da instituição ao longo do tempo. 
de nosso sistema de informação. Não é de admirar que elas nos recrutem facilmente para que nos juntemos à sua autocontemplação narcisista. Quaisquer problemas sobre os quais tentemos refletir são transformados automaticamente nos próprios problemas organizacionais dessas instituições. (Douglas, 1986, 109)

Segundo a autora, a memória institucional parece escolher os fatos do passado e aqueles silêncios que julga contribuir para o manejo das tensões políticas. O reconhecimento e papel das diversas esferas de poder nas quais a história, na medida em se reflete nos discursos de seus membros, é reforçada e transformada nos seus problemas organizacionais mais cotidianos. A memória institucional se torna se torna coisa monumental nos discursos de seus membros e nos compilados documentais e a história ganha a capacidade de reger processos coletivos e institucionais no presente. Nesse sentido, os documentos dos dossiês tecem fios temporais de legitimidade que estruturam as relações institucionais ao longo do tempo na medida com que determinados fatos são escolhidos para fazer parte de sua memória, de seus membros e de sua história.

Com essa perspectiva em mente, abordo as narrativas monumentais que remontam os processos históricos institucionais de criação da Escola Superior de Ciências da Saúde (ESCS) como base nos discursos e posicionamentos políticos e ideológicos que meus interlocutores evocaram durante a pesquisa de campo. Coloco os documentos institucionais - no que diz respeito não apenas ao caráter factual e histórico dos documentos legais dispostos nos dossiês, assim como os discursos e silêncios escondidos nas entrelinhas desses documentos - em diálogo com falas e comedimentos registrados no diário de campo.

\section{DO ARQUIVO INSTITUCIONAL À NARRATIVA MONUMENTAL}

Assim, faço aqui uma análise dos documentos dispostos nos dossiês mencionados anteriormente nas suas interfaces com os registros no diário de campo para que, permutandose continuamente de um universo documental para os registros etnográficos, fosse possível compreender momento presente de transformação pelo qual a Escola Superior de Ciências da Saúde (ESCS) está passando, ou seja, sua transformação em universidade. Para que fique mais clara a forma com que serão apresentados os documentos institucionais, neste capítulo é importante ressaltar o fato de que abordo documentos produzidos em diferentes datas por diferentes fontes institucionais. Atenção à temporalidade desses documentos é importante e 
deve ser mantida em foco para que se perceba a maneira pela qual os processos institucionais se atualizavam no presente.

Consolidada a partir de uma perspectiva voltada para o alcance de novos objetivos relacionados ao ensino profissional em saúde, a Fundação de Ensino e Pesquisa de Ciências da Saúde (FEPECS) tem como missão oficialmente emoldurada em seu saguão de entrada, conforme é possível ver na Foto 1: "Formular e implementar a formação e o desenvolvimento de pessoas, a gestão do conhecimento, pesquisa e inovação tecnológica conforme as políticas públicas de saúde", tal missão também está disposta no texto de seu regimento interno (FEPECS, 2002, 46).

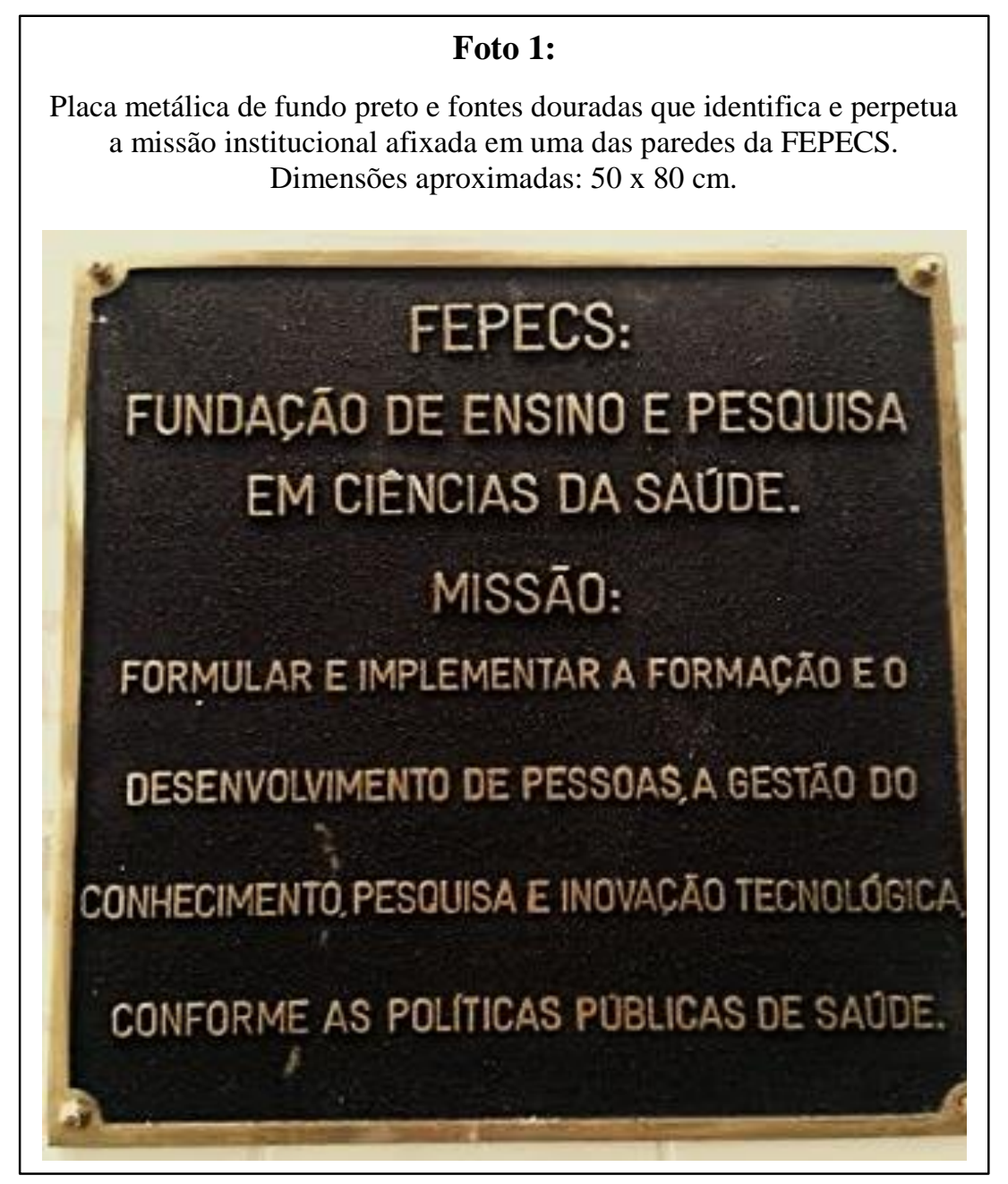

É possível ver o vínculo com o Estado sendo explicitado na conformidade com as políticas públicas de saúde e ideias de "desenvolvimento", "gestão" e "inovação" evocados na missão institucional da Fundação de Ensino e Pesquisa em Ciências da Saúde (FEPECS), esses 
que refletem valores morais e ideológicos os quais carregam em si o caráter das políticas nacionais de saúde. Ao olhar para o discurso institucional no presente na página institucional da Fundação de Ensino e Pesquisa em Ciências da Saúde (FEPECS) na internet para consultar o histórico ${ }^{2}$ dessa instituição vemos a FEPECS se autocelebrar como a "resultante de um processo que abrange mais de quatro décadas de trabalho ininterrupto, orientado ao desenvolvimento de habilidades e competências dos servidores e profissionais de saúde que compõem o sistema de saúde" do Distrito Federal. (FEPECS, 2013, 3)

Como "mito de origem" que a Fundação de Ensino e Pesquisa de Ciências da Saúde (FEPECS) tem de seu passado, percebe-se que tal enormidade histórica imputa uma determinada carga de valores e ideais ligados ao próprio projeto político de democratização do Estado através das políticas públicas voltadas para o Sistema Único de Saúde (SUS). Na representação que faz de si mesma dentro do percurso histórico de construção do sistema de saúde público do Distrito Federal, a Fundação de Ensino e Pesquisa de Ciências da Saúde (FEPECS) evoca uma profundidade histórica e institucional latente. $\mathrm{O}$ fato de que a FEPECS, que completou 12 anos de existência em 2013 contar sua história remetendo-se aos primórdios de construção do sistema público de saúde do Distrito Federal, que tem mais de 60 anos, faz sua história ser algo monumental no seu contexto interno. Ela se autopromove segundo sua auto referência histórica e posição de autoafirmação e autocontemplação nos discursos de seus membros de modo ostensivo e magnificente, pois tem sua gênese à construção associada à construção do próprio sistema público de saúde do Distrito Federal, que veio junto com a construção da própria cidade de Brasília, "capital da esperança", e fez parte do projeto de desenvolvimento da nação brasileira moderna e mais integrada.

O caráter integrador e democrático das políticas de saúde dessa época caracterizavam um projeto de nação que, nas entrelinhas das grandes políticas públicas do Estado voltadas ao crescimento e desenvolvimento do sistema de saúde do país, tinha os mesmos princípios ideológicos refletidos no desenvolvimento de novas formas de gerir e implementar a formação médica no país; e cuja Escola Superior de Ciências da Saúde (ESCS) foi uma das expressões institucionais desse movimento.

2 Histórico institucional da Fundação de Ensino e Pesquisa em Ciências da Saúde (FEPECS) <<http://www.fepecs.edu.br/index.php/institucionalgeral〉> Página consultada em 11 de abril de 2014. 
Brasília, capital nacional, foi inaugurada no dia 21 de abril de 1960, fez parte de um processo modernizador e de desenvolvimento rumo ao interior do país. Junto com a criação da cidade veio a criação de sua estrutura política de gestão e a construção da rede de assistência de saúde, a qual foi institucionalizada na Fundação Hospitalar do Distrito Federal (FHDF), primeiro órgão gestor da saúde no Distrito Federal e que constituiu expressão institucionalmente estruturada da gestão pública do sistema de saúde local. Além de hospitais e centros de saúde, sob o domínio hierárquico e administrativo da Fundação Hospitalar, foi criada a Escola de Auxiliares de Enfermagem de Brasília (EAEB) nos primeiros anos da década de 1960. A Escola de Auxiliares de Enfermagem de Brasília (EAEB) tinha o objetivo de formar recursos humanos para fazer parte da organização dos serviços de assistência na saúde pública que vinha sendo construída junto com a cidade de Brasília e, principalmente, suprir o sistema público de assistência local com profissionais de nível técnico e médio. A missão da Escola de Auxiliares de Enfermagem de Brasília (EAEB) era "prover a cidade de Brasília de pessoal especializado em enfermagem", segundo o texto que foi consultado na página on-line da FEPECS citado anteriormente na qual é traçado o histórico do seu surgimento no contexto da construção da cidade de Brasília. A Escola de Auxiliares de Enfermagem de Brasília (EAEB) funcionou durante treze anos com o mesmo nome quando, em 1973, foi reconhecida pela então Secretaria de Educação e Cultura do Distrito Federal (SEC-DF) como um "estabelecimento de ensino profissionalizante" (FEPECS, 2013, 1) ao mesmo tempo que seu nome passou a ser “Escola Técnica de Saúde de Brasília” (ETESB), existente até o momento.

A mudança do nome "Escola de Auxiliares de Enfermagem de Brasília" (EAEB) para "Escola Técnica de Saúde de Brasília" (ETESB) não foi apenas estético e simplesmente nominal, fez parte de uma transformação institucional que aconteceu na época. A ênfase no lado técnico da formação de recursos humanos para atuar no recém criado serviço público de saúde do Distrito Federal não era em vão. A mudança vinha dos níveis políticos e ideológicos mais amplos das políticas de ensino em saúde locais e nacionais e se refletia na ampliação da missão institucional durante o processo dessa mudança, que agora visava, além de "prover a cidade com pessoal especializado", incentivar diretamente seu "engajamento no mercado de trabalho da área da saúde sempre com o imperativo de formar profissionais de nível médio para a área da saúde” (ETESB, 2011, 1), segundo o regimento interno da dessa escola. 
Nas palavras de um médico que se formou nos primeiros anos da capital está a seguinte história sobre a época de criação do sistema público de saúde no em Brasília:

\begin{abstract}
No início, naturalmente, as pessoas que compunham a fundação [FHDF] não eram de Brasília e havia um sonho em vir para cá com a implementação dos novos projetos por volta dos anos 60. A UNB era um polo agregador de fomento de novos projetos. [...] Quando eu era aluno da UNB, no período da ditadura tiveram muitas mortes e perseguições em torno dessas novas ideias e projetos. $\mathrm{O}$ assunto corria na mente e conversas entre os estudantes na época. Mas a UNB ficou meio isolada no DF durante a ditadura, muito distante da realidade e muito perto do lucro; ainda mais no curso de medicina, que se via cada vez mais tecnicizado e englobado pela lógica do mercado. Em contrapartida, a Fundação Hospitalar [FHDF] se fez a pergunta sobre as razoes de porque não se ter sua própria escola de formação em saúde, processo de questionamento que deu origem à ESCS, à ETESB. [...] Não se pode é esquecer das razoes que motivaram a criação dessas escolas, que era a unificação entre serviço de saúde e educação em saúde. (Médico formado em Brasília na década de 1970. Fala registrada no diário de campo, 13/11/2013)
\end{abstract}

As primeiras camadas intelectuais e médicas locais eram compostas por pessoas formadas fora de Brasília. As primeiras turmas candangas de medicina se formaram por volta do início da década de 1970, na Universidade de Brasília (UNB), única instituição de ensino superior de medicina na localidade que oferecia o curso de graduação em medicina na época. No entanto, o currículo do curso de medicina da UNB parecia ser enviesado para as especialidades disciplinares tradicionais e lógicas do mercado de tecnologias da medicina especializada, voltada ao modelo hospitalocêntrico. Ao mesmo tempo, havia o ímpeto disseminado entre os estudantes e intelectuais na época em torno da criação de novas propostas e projetos de ensino em cursos na área da saúde que fossem implementados na cidade de Brasília, cuja Escola Técnica de Saúde de Brasília (ETESB) fez parte pelo fato de ter sido a primeira instituição escolar no Distrito Federal vinculada às estruturas da gestão pública do Estado no que diz respeito à formação de recursos humanos para atuar no sistema público de saúde local. Isso faz dela a primeira expressão institucional local que buscou imbricar a gestão de uma escola de saúde dentro das estruturas de gestão administrativa de saúde do próprio Estado.

Vale salientar nesse ponto que não logro reflexões muito detidas sobre a Escola Técnica de Saúde de Brasília (ETESB). Por mais que ela faça historicamente parte da construção original do sistema público de saúde do Distrito Federal e seja a instituição pública de ensino em saúde mais antiga administrada pelo Estado no Distrito Federal, a Escola Técnica de Saúde de Brasília (ETESB) pareceu não ser relevante politicamente do ponto de vista dos próprios atores institucionais envolvidos com o processo de transformação institucional 
etnograficamente acompanhado. Explicando melhor, por mais que a Escola Técnica de Saúde de Brasília (ETESB) tenha 52 anos de história na formação de profissionais da saúde no Distrito Federal, depois que a Escola Superior de Ciências da Saúde (ESCS) foi criada em 2001, a relevância e força política da Escola Técnica de Saúde de Brasília (ETESB) no contexto interinstitucional local pareceu ter sido diminuído diante do projeto de ensino diferenciado que a Escola Superior de Ciências da Saúde (ESCS) trouxe a partir de 2001. A própria história da ETESB parece ter ficado opaco, a reboque do projeto "inovador" e "paradigmático" que foi a criação da Escola Superior de Ciências da Saúde (ESCS), que parecia liderar politicamente o processo de transformação em Universidade de Ciências da Saúde do Distrito Federal (UNISUS). Chego à essa conclusão a respeito da ETESB porque foi possível perceber, através da etnografia do processo de transformação institucional de criação da UNISUS que, em certa medida, a posição da Escola Técnica de Saúde de Brasília (ETESB) na arena política de discussão sobre a criação da UNISUS era praticamente irrelevante do ponto de vista político e ideológico que movimentava o processo. Primeiro porque sua própria profundidade histórica está silenciada no dossiê sobre a criação da FEPECS, que praticamente não faz menção alguma à presença da ETESB no contexto da rede institucional criada, e segundo, devido à pouca influência ideológica que ela tem quando contrastada com a Escola Superior de Ciências da Saúde (ESCS).

Em 1976, quando a Escola Técnica de Saúde de Brasília (ETESB) estava com 13 anos de funcionamento, a Fundação Hospitalar do Distrito Federal (FHDF), que era o órgão centralizador da gestão da saúde no Distrito Federal, inaugurou o Centro de Desenvolvimento de Recursos Humanos para a Saúde (CEDRHUS), o qual hoje corresponderia à Fundação de Ensino e Pesquisa de Ciências da Saúde (FEPECS). O CEDRHUS foi uma instituição pública distrital que buscou viabilizar o modelo de atenção proposto nacionalmente na época da transferência da capital nacional para Brasília nos anos 1960 e deu início à divulgação de projetos de implementação de programas de formação voltados para a saúde comunitária e social no âmbito do DF. O Centro de Desenvolvimento de Recursos Humanos para a Saúde (CEDRHUS) atuou como um ente centralizador das implantações de instituições educacionais administradas pelo Estado que se instituíam no Distrito Federal. A agenda de políticas públicas viabilizadas pelo CEDRHUS eram voltadas para o aprimoramento da educação em saúde e tinha natureza idealmente integradora das ações de saúde mantidas pelo Estado no Distrito Federal. O Centro de Desenvolvimento de Recursos Humanos para a Saúde (CEDRHUS) é 
atualmente considerado no discurso histórico da Fundação de Ensino e Pesquisa de Ciências da Saúde (FEPECS) como tendo sido um "órgão de ensino especializado para a capacitação de servidores da antiga Fundação Hospitalar do Distrito Federal (FHDF) na execução das ações de saúde dirigidas à clientela do SUS" (FEPECS, 2013, 1), sugerindo fomentar uma forma indireta de atingir os usuários do sistema público de assistência de saúde no Distrito Federal, segundo, mais uma vez, o documento do histórico institucional consultado no site da instituição.

Até a década de 1990 a ênfase da gestão da educação em saúde no Distrito Federal era voltada para o ensino técnico com vistas à formação de recursos humanos para atuar no próprio sistema assistencial da capital. Aconteceu que a conjuntura geral das políticas nacionais passou por um grande e amplo processo de transformação, que se reporta à Constituição Federal de 1988, conhecida como "Constituição Cidadã" e, dois anos depois, na criação da Lei 8.080 de 1900, lei que institui o Sistema Único de Saúde (SUS) à nível nacional. Os ideários de ordem e de progresso que formaram o mote político do Estado brasileiro no início do século XX deram lugar aos valores da democracia e da cidadania que se instauraram no contexto estatal e no caráter das políticas pública do Estado. Foi um processo de democratização das políticas e da gestão pública do Estado que atualizou ideologicamente os valores que moviam as políticas públicas voltadas à saúde no Brasil. Cidadania e participação se tornaram valores candentes que conferiram identidade e caráter às políticas públicas voltadas para a oferta de serviços de saúde, educação e formação de profissionais da saúde na época.

Em meio ao processo mais amplo de transformação da ideologia política nacional para a saúde, no ano 2000, a Fundação Hospitalar do Distrito Federal (FHDF) foi extinta e substituída pela atual Secretaria de Estado de Saúde do Distrito Federal (SES-DF). Concomitante à essa transformação das estruturas da gestão e administração das instituições de saúde ao nível da Secretaria de Estado de Saúde do Distrito Federal (SES-DF) foi feito um projeto de lei que tratou da criação da Fundação de Ensino e Pesquisa em Ciências da Saúde (FEPECS), à qual o antigo Centro de Desenvolvimento de Recursos Humanos para a Saúde (CEDRHUS) deu lugar nesse mesmo processo de transformação e mudança administrativa. Isto é, colocando de maneira simplória, pode-se dizer que o Centro de Desenvolvimento de Recursos Humanos para a Saúde (CEDRHUS) esteve para a Fundação de Ensino e Pesquisa em Ciências da Saúde (FEPECS), da mesma maneira que a Fundação Hospitalar do Distrito 
Federal (FHDF) esteve para a atual Secretaria de Estado de Saúde do Distrito Federal (SES$\mathrm{DF})$.

A cronologia das mudanças institucionais históricas da gestão da educação em saúde no contexto do ensino profissional no Distrito Federal tem relevância para a compreensão do processo de transformação institucional que diz respeito ao "Projeto UNISUS", um processo ainda em curso e que não se encerrou. Vista de uma perspectiva histórica, a transformação atual da ESCS e da ETESB em UNISUS pode ser vista como uma atualização da série de transformações que a rede de instituições de ensino em saúde no Distrito Federal veio passando ao longo de sua história. Em resumo, em torno de uma Escola técnica criou-se um Centro de formação de recursos humanos que se transformou em uma Fundação de ensino que atualmente abarca o processo de construção de uma Universidade. O processo de alargamento e transformações institucionais ao longo do tempo são evidentes.

O objetivo desse esforço analítico sobre a história institucional das escolas públicas de saúde no Distrito Federal é apreender etnograficamente a ponta final dessa cadeia de transformações em aberto nesse processo histórico de transformações institucionais acontecem tanto nos níveis mais amplos das políticas e ideologias de Estado quanto no contexto local das disputas em torno do projeto de lei que visa a criação da UNISUS no Distrito Federal, o qual será discutido com mais ênfase no último capítulo.

Saindo da narrativa monumental que envolve a criação da Fundação de Ensino e Pesquisa em Ciências da Saúde (FEPECS) e da Criação da Escola Superior de Ciências da Saúde (ESCS), na sessão seguinte passo ao nível interno do processo de criação dessas suas instituições por volta do ano 2001 no Distrito Federal.

\section{DA CRIAÇÃO DA FEPECS E DA ESCS}

Como base para referência visual do processo de criação da Fundação de Ensino e Pesquisa em Ciências da Saúde (FEPECS) e da Escola Superior de Ciências da Saúde (ESCS) em 2001, a Figura 1, a qual foi extraída do dossiê sobre a criação da FEPECS traz o cronograma de implantação dessas instituições. 


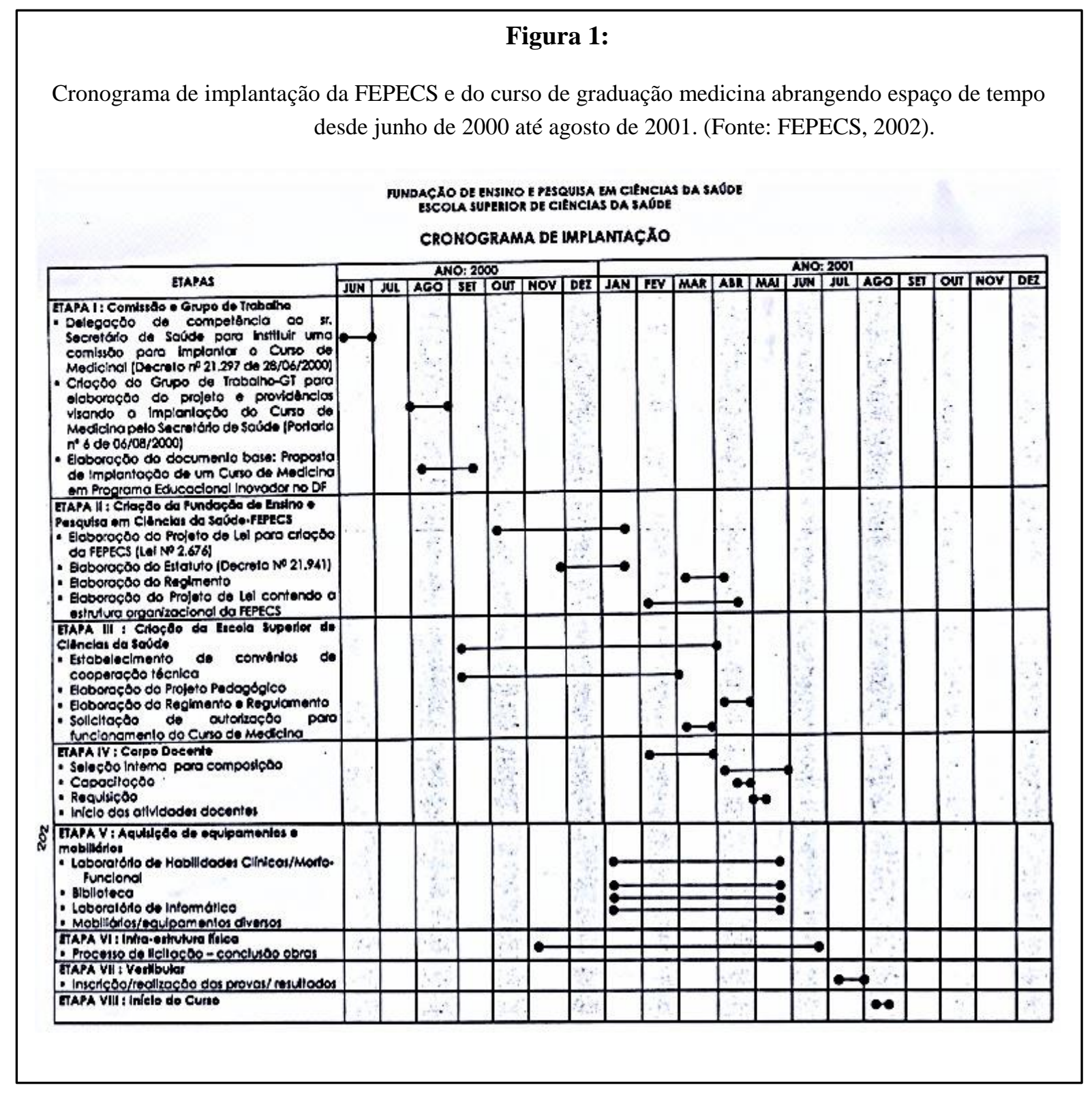

Para cada ponto em cada etapa da figura existe uma série de documentos oficiais que detalham passo a passo o processo da criação, mas apenas numa linguagem jurídica. São séries longas de documentos das quais foram destacados apenas aqueles que fizeram parte do recorte para a compreensão do sentido da disputa atual do processo de transformação institucional que envolve o Projeto UNISUS, principalmente atas de reuniões do grupo de trabalho e alguns documentos internos publicados durante o processo de criação dessas instituições, por volta do ano 2000. 
As reuniões do grupo de trabalho responsável pela implantação do projeto de lei que criava a Fundação de Ensino e Pesquisa em Ciências da Saúde (FEPECS) e da Escola Superior de Ciências da Saúde (ESCS) aconteceram durante quase todo o período de tempo compreendido pelo gráfico da Figura 1 e datam de oito de agosto de 2000, quando aconteceu a primeira reunião, e vão até o dia dezoito de junho de 2001, totalizando trinta e duas reuniões de acordo com a numeração e datas das atas. A distribuição no tempo das atividades marcadas pelo cronograma de implantação na Figura 1 comunica visualmente a simultaneidade das ações institucionais que foram acontecendo ao longo do processo de criação e cada ponto disposto na primeira coluna das "etapas" corresponde à uma sequência de documentos do dossiê sobre a criação das instituições que, se forem vistos em conjunto, esboçam uma narrativa documental que conta a história da concepção e nascimento da Fundação de Ensino e Pesquisa em Ciências da Saúde (FEPECS) e da Escola Superior de Ciências da Saúde (ESCS).

Foi interessante analisar os relatos nas atas das reuniões do grupo de trabalho ao mesmo tempo em que se pôde consultar os documentos legais produzidos em torno da época da criação para marcar o posicionamento de cada membro do grupo de trabalho dentro do processo e quais foram seus papéis dentro do processo de criação das instituições e manejo do processo. A Foto 2 traz os nomes e os cargos institucionais das pessoas que compuseram o grupo de trabalho. Delegada a competência ao então secretário de saúde, foi publicada a Portaria número 6 , de 2 de agosto de 2000, a qual traz os nomes e cargos dos componentes do grupo de trabalho responsável pela criação da nova instituição. Essa portaria foi eternizada para além do dossiê ao ser transferida para uma placa de mármore, conforme trago na Foto 2, placa que fora pendurada no saguão de entrada da FEPECS, evidenciado a importância simbólica que esse grupo de pessoas teve para a concepção e desenvolvimento dos trabalhos que levaram à implantação da Escola Superior de Ciências da Saúde (ESCS) em Brasília.

Convém destacar quem eram as pessoas que compunham o grupo de trabalho. Oito delas eram vinculadas ao Centro de Desenvolvimento de Recursos Humanos para a Saúde (CEDRHUS), três eram vinculadas à Universidade de Brasília (UNB) e uma ao Centro Universitário de Brasília (UNICEUB). A presença numérica maior das figuras da gestão pública da saúde no Distrito Federal, principalmente por parte dos dirigentes de órgãos internos da Secretaria de Saúde, mostra o quão inclinado politicamente o projeto de criação estava para as questões políticas do Governo do Distrito Federal (GDF). 


\section{Foto 2:}

Placa de mármore preto com fontes douradas trazendo o texto da Portaria $\mathrm{N}^{\mathrm{o}} 6$, de 2 de agosto de 2000 , publicada pela SES-DF, afixada na portaria da FEPECS.

Dimensões: 1,5 x 2,5 m.

GDF-SECRETARIA DE ESTADO DE SAÚDE-FEPECS

EM 29 DE JUNHO DE 2000,0 GOVERNADOR DU DISURITO FEDERAL, JOAQUIM DOMINGOS RORIZ, ATRAVES DO DEGRETO VNe 297 , DELE COMPETENCIA AO SECRETARIO DE ESTADO DE SAUDE DO I LULO FEDERA JOFRAN FREJAI PARA CONSTITUIR COMISSAOO DESTINADA A HEEALUIAR ESTUDOS E ADOTAR AS PROVIDENCIAS, NO SENTIDO DE IMPLANTAR E FAGAER FUNCCONAR UMA EACULDADE DE MEDICINA A SER MANTIDA PEIO GOUAR (1) DO DSSTLILO EEDERAL.

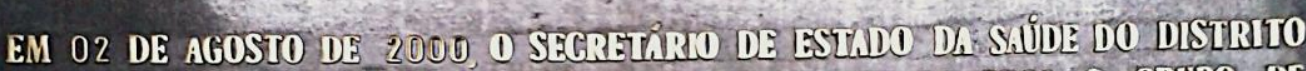

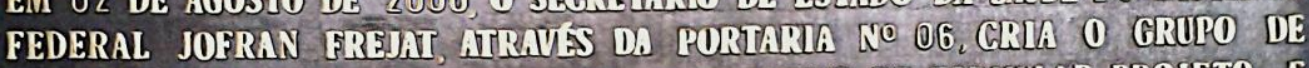

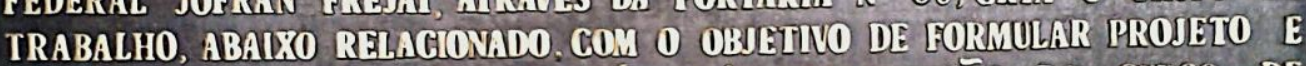

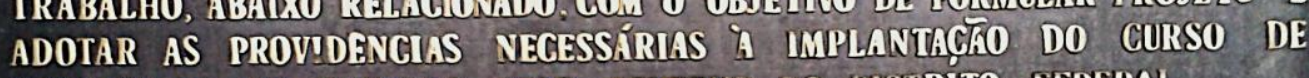
MEDICINA A SER MANTIDO PELO GOVERTC DO DISTRITO FEDERAL

PAULO AFONSO KALUME REIS SEGRETARO-ADJUNTO DE SAUUDE COORDENADOR DO GRUPO DE TRABALHO

- raimundo bandeira da rocha chefe da procuradoria jurídCa da fHDF ROSÁNGELA CONDE WATANABE DIRETORA DO CENTRO DE DESENVOLVIMENTO DE RE URSOS HUMANOS PARA SAUDE

JOSE F. NOBRE FORMIGA FILHO DIRETOR DO DEPARTAMENTO DE RECURSOS MEDCO-ASSISTENCIAIS DA FHDF

IVAN GONZAGA BARBOSA DIRETOR DA SECGAOO D RESI ËNCIA MEDICA MARIA CRISTIN FERREIRA SENA DIRETORA DA DIVISĀO DE PESQUISA DO CEDRHUS CÂNDIDA ELIZABETH DE A.KANHAK MÉDICA=ASSISTENTE DO CEDRHUS CLÁUDIO DUARTE DA FONSECA S CRETÁRIO DE POLITHCAS DE SAÚDE MINISTERIO DA SAUDE

ABIB ANI CURY DIRETOR DA FACULDADE DE GIENCIAS DA SAUDE DO UNICEEB

JOSI̊́ GARROFE DÓREA COORDENADOR DE PÓS-GRADUAC̄ÃO EM GISN IAS DA SAUDE DA UNB

MOURAD IBRAHIM BELACIANO DIRETOR DA FACULDADE DE CIENCIAS DA SAEDE DA GNB

DAU O SÉRGIO BRANGA VIGE-DIRETOR DA FACULDABE DE GIENCIAS DA SAUDE DA ENB 
Importante ressaltar também que o idealizador do projeto pedagógico, Mourad Belaciano, membro do grupo de trabalho que redigiu o "Documento Base", que serviu como o início da feitura do projeto pedagógico da escola, era diretor da Faculdade de Ciências da Saúde da Universidade de Brasília. Então por que tal projeto inovador de um curso de medicina com metodologia diferente da tradicional não foi implantado na UNB? A resposta à essa pergunta está no fato de que o secretário de saúde, Jofran Frejat à época, teria buscado firmar um vínculo de cooperação entre a Secretaria de Saúde e a Universidade de Brasília (UNB), mas sem sucesso. Esse é um fato mencionado até hoje pelos sujeitos envolvidos, estando registrado numa ata de reunião ordinária do conselho deliberativo da FEPECS que aconteceu no dia 10 de dezembro de 2013, onde um dos membros do conselho disse que "a FEPECS foi criada devido à várias tentativas frustradas do Dr. Jofran Frejat, secretário de saúde à época do Prof. Mourad que não conseguiram convencer a UNB a integrar-se com a SES-DF” (FEPECS, 2013, 4). Não havendo espaço político para a criação de vínculos com a UNB, o governo local então decidiu criar sua própria escola de medicina.

A reunião inaugural da comissão - ou grupo de trabalho, os dois termos são utilizados no dossiê -, foi no dia 8 de agosto de 2000 e foi a primeira e única reunião em que o então secretário de saúde esteve presente. Sua função na reunião foi divulgar a ideia da nova fundação e da nova escola de medicina. Na ocasião, o secretario de saúde do DF na época, Jofran Frejat, falou da

\footnotetext{
importância social da criação da Faculdade Cidadã, que terá como marco inicial a criação de um novo curso de medicina, a qual será implantada sem a necessidade de pesados investimentos, uma vez que será usada a estrutura pública médico-hospitalar de Brasília. Para tanto, com o apoio do Governador do Distrito Federal, Dr. Joaquim Roriz, [...] foi previsto na nova proposta de estruturação da Secretaria de Saúde a criação da Fundação de Ciências da Saúde, além de permitir que posteriormente o CEDRHUS venha integrar essa fundação, como órgão coordenador do curso. A faculdade de medicina poderá ser viabilizada através da celebração de convênios com as universidades: de Marília, Londrina e Brasília. [...] A formação de médicos generalistas capacitados para o exercício profissional que atenda à política de saúde vigente com ênfase ao atendimento primário e aos programas de saúde voltados à medicina social. (FEPECS, 2002, 205. Grifo meu.)
}

O trecho transcrito é o registro da fala que o então secretário de saúde Jofran Frejat que, como já se falou no início do primeiro capítulo, é médico de formação, foi dirigente de instituições públicas da saúde no Distrito Federal e o fato mais significativo é que ele foi membro da Assembleia Constituinte de 1988, cuja Constituição promulgada é reconhecida como "Constituição Cidadã". É evidentemente o vínculo simbólico entre a Constituição Federal 
de 1988 e a criação da escola de medicina em Brasília quando Frejat, sujeito político que carregava as palavras do Estado na reunião instituinte do grupo de trabalho responsável pela criação da escola, a caracteriza como "Faculdade Cidadã", o que exprime os valores amplos do projeto de criação da nova escola de medicina em Brasília lado a lado com os valores de construção ideológica e democrática da própria nação e Estado brasileiros na base do novo projeto que se implementava.

Na mesma retórica de evocação dos valores e vinculação simbólica com o projeto de nação brasileira que veio sendo construído no final do século $\mathrm{XX}$, o chefe de gabinete do ministro da saúde na época, que também estava presente na reunião inaugural do grupo de trabalho, enfatizou que existia "interesse do ministro da saúde em apoiar somente uma proposta de um curso de medicina radicalmente diferente do modelo tradicional que visa a formação de médicos generalistas para atuarem no Programa Saúde da Família” (FEPECS, 2002, 205). Os efeitos de suas falas eram divulgadores de um projeto político mais amplo e, acima de tudo, tinha caráter inaugural e instituinte do grupo que conduziria os trabalhos para a criação da instituição projetada. Além disso, a ênfase na formação de profissionais para atuarem na atenção básica era quase uma ordem, uma vez que as políticas nacionais voltadas para a saúde continham em si os princípios de universalizar e equalizar o acesso da população aos serviços de saúde básicos e criar o curso superior de medicina. O projeto da nova escola visava a formação de médicos dentro do próprio sistema público de saúde e para este sistema, num esquema de retroalimentação que se auto sustentaria a partir de uma lógica integradora tanto nos níveis da gestão quanto nos níveis do método pedagógico adotado.

A noção de efeito das falas das figuras públicas nas reuniões da comissão de criação da nova escola deve ser desdobrada. Nesse tipo de fala política, inaugural, vinculavam-se os níveis maiores de construção da nação brasileira das políticas públicas do Estado aos níveis mais concretos dos processos cotidianos do mundo político, e a criação dessa escola de medicina em Brasília em 2001 era uma expressão institucional concreta desse movimento. Bourdieu (1982) aponta os níveis que estruturam as trocas simbólicas do mundo social em que a linguagem tem uma carga de poder representativo sobre a construção da realidade social que é estruturada segundo a percepção dos agentes sociais que manejam os projetos estatais. $\mathrm{O}$ autor coloca $\mathrm{O}$ seguinte: 
Eles partilham com os demais uma intenção que se pode designar como performativa ou, mais simplesmente, mágica: o insulto, assim como a nomeação, pertence à classe dos atos de instituição e destruição mais ou menos fundados socialmente, através dos quais um indivíduo, agindo em seu próprio nome ou em nome de qualquer grupo mais ou menos importante numérica e socialmente, quer transmitir a alguém o significado de que ele possui uma dada qualidade, querendo ao mesmo tempo cobrar de seu interlocutor que se comporte em conformidade com a essência social que lhe é atribuída. (Bourdieu, 1982, 82)

O fato de que o secretário de saúde estar presente única e exclusivamente na primeira reunião do grupo de trabalho responsável pela criação da FEPECS e da ESCS mostra a força representativa que sua figura tinha dentro do processo de criação dessas instituições e a relevância política da proposta. A função do secretário de saúde Jofran Frejat na reunião foi inaugural e instituinte. Sua figura trazia em si o próprio Estado. Suas palavras ganharam força instituinte não apenas narrando o trajeto ideológico que percorre no processo de criação da nova escola de medicina, as suas palavras tinham a legitimidade e autorização para fazer coisas acontecerem.

O porta voz autorizado consegue agir com palavras em relação à outros agentes e, por
meio do seu trabalho, agir sobre as próprias coisas, na medida em que sua fala
concentra o capital simbólico acumulado pelo grupo que lhe conferiu o mandato [...]
As condições a serem preenchidas para que um enunciado performativo tenha êxito
se reduzem à adequação do locutor (ou melhor, de sua função social) e do discurso
que ele pronuncia. Um enunciado performativo está condensado ao fracasso quando
pronunciado por alguém que não disponha do 'poder' de pronunciá-lo [...] Contudo,
cumpre ressaltar que o êxito destas operações de magia social que são os atos de
autoridade (ou então, o que dá no mesmo, atos autorizados) está subordinado à
confluência de um conjunto sistemático de condições interdependentes que compõem
os rituais sociais. (Bourdieu, 1982, 89)

O Estado agiu através de suas palavras quando foi ele quem proferiu a fala inaugural do grupo de trabalho responsável a dar início ao processo de criação da Escola Superior de Ciências da Saúde (ESCS). Como representante de um grupo social do qual ele era porta voz, ou seja, do campo político das coisas públicas, ele carregava em suas palavras a mensagem que este grupo queria passar, isto é, que o Estado, no caso, quer projetar. O capital que ele simbolizava teve função idônea institucional no processo de criação da nova instituição e ele era detentor desses "atos de autoridade" nos rituais do Estado dos quais Bourdieu discute.

Na parte prática do processo de implantação da instituição e como representante do grupo intelectual médico que projetou as bases pedagógicas da no nova escola distrital de medicina de Brasília, Mourad Belaciano, na época, diretor da Faculdade de Ciências da Saúde da UNB, foi quem ocupou a função de conduzir a elaboração do projeto pedagógico da nova 
escola durante o processo de criação. O protagonismo de Mourad Belaciano nas reuniões da comissão de criação, sua função e papel institucional expressa nas atas de reuniões consultadas e com base nos relatos dos estudantes registrados no diário de campo, teve seu nome vinculado - para não dizer eternizado - ao corpo estudantil da escola ao ter seu nome escolhido pelos estudantes para compor o nome do centro acadêmico, o qual se chama: Centro Acadêmico Mourad Ibrahim Belaciano (CAMIB). O nome "CAMIB" era utilizado quando os discursos acionavam a representatividade do corpo estudantil da escola, como em assembleias e quando a conversa se voltava à questões políticas. Entretanto, entre os estudantes, quando eles se referiam ao espaço físico do centro acadêmico enquanto espaço de socialização, descanso e estudo era referido na maioria das vezes como "Toca da Coruja"3.

O que quero frisar neste ponto da argumentação é a direção do eixo analítico para as questões de cunho histórico e político. A escolha do nome do centro acadêmico dos estudantes de medicina colocou a figura de Mourad Belaciano num nível de preservação histórica de sua função idealizadora e ação política junto à Frejat dentro do processo de criação da escola de medicina desde sua gênese. Que ações foram essas? Mourad, na época, diretor da Faculdade de Ciências da Saúde da UNB, e hoje, membro titular do conselho deliberativo da FEPECS, foi o responsável pela redação do chamado "Documento Preliminar, Proposta de Implantação de um Curso de Medicina em Programa Educacional Inovador no Distrito Federal" - ou "Documento Base" - com vistas à "subsidiar a discussão interna da SES-DF" (FEPECS, 2002, 179). Esse documento foi a primeira concretização documental escrita do projeto de criação da FEPECS e da ESCS no Distrito Federal o qual foi apresentado ao grupo de trabalho responsável pela criação da FEPECS na segunda reunião da comissão destinada à tomar providências no sentido de implantar um curso de medicina a ser mantido pelo governo do DF. O documento foi discutido e acrescido de dados produzidos por membros deste grupo de trabalho ao longo das reuniões e fora delas sobre a situação da saúde pública atual e sobre a contextualização que o

\footnotetext{
${ }^{3}$ Localizada no subsolo do prédio mais novo da escola, a "Toca da Coruja", ou simplesmente "Toca", que antes servia como depósito da Escola, foi ocupada pelos estudantes na noite do dia 13 de agosto de 2013 e hoje é o espaço principal de convivência e socialização estudantil dentro ESCS. Nesse espaço, sede da entidade institucional representativa dos estudantes e politicamente organizada, os estudantes realizam diversificadas séries de atividades, desde reuniões periódicas semanais para a discussão da vida acadêmica, reuniões de grupos de estudo, socializações, festas, etc.
} 
projeto da FEPECS tinha no quadro das políticas públicas voltadas para a educação em saúde e traz uma descrição detalhada do modelo pedagógico que estava sendo proposto.

"Curso de Medicina da Secretaria de Estado de Saúde do Distrito Federal: Um Programa Educacional Inovador" (FEPECS, 2002, 285) é o título do documento produzido pelo grupo de trabalho a partir do documento preliminar. Sendo um documento fundador do universo ideológico que o projeto trazia, além de ter sido com base neste documento que o próprio projeto pedagógico do curso foi feito, trechos do texto nesses documentos se repetem e isso revela que foi num processo de acumulações e construções sucessivas que o projeto político e pedagógico da escola foi confeccionado. Para termos melhor perspectiva quanto à reminiscência monumental que a história da instituição traz, transcreve-se aqui trechos do documento e as mensagens políticas nele dispostos:

Com o fim da II Guerra Mundial e a introdução da carta dos Direitos Humanos houve tendência à ampliação da cobertura, até então quase totalmente securitária, sob o enfoque do bem estar social da população carente de amparo pós guerra. Assumida pelo Estado, essa organização assistencial teve de conviver com as resistências que tentavam reverter essa tendência socializante. (FEPECS, 2002, 291)

Brasília foi um modelo experimental desses avanços, com sua proposta inovadora importante de assistência, nos moldes da evolução que transcorria. Tanto o Plano Diretor de Saúde do DF, através da regionalização, hierarquização e descentralização, com seus agentes de saúde, como pela experiência educacional docente assistencial da Universidade de Brasília, estiveram adiante do próprio sistema previdenciário, do sistema de saúde e do sistema de ensino até então existente. (Ibid., 293)

As dificuldades e as insuficiências detectadas no setor saúde não são apenas de ordem financeira e gerencial. Os problemas enfrentados pela prática médica no atual contexto de desenvolvimento sócio econômico do país apontam na direção de sua formação profissional. [...] A dinâmica da renovação da formação médica para superar as necessidades apontadas pelos serviços públicos e privados de saúde é também uma exigência da sociedade, que vem exigindo dos educadores muito mais do que o papel de ensinar. [...] Os avanços contínuos da ciência e a integração de novos conteúdos tem sido sempre apontados como problemas difíceis de superar, sendo também difícil romper com os modelos tradicionais de ensino. (Ibid., 296)

Fazendo um recuo longe no tempo e remetendo-se ao período da II Guerra Mundial, a justificativa de criação da instituição mostra o enfoque dado papel do Estado e seu dever de prover a saúde de sua população. A justificativa, nas entrelinhas, faz críticas ao regime militar enquanto uma "resistência à tendência socializante" das políticas de assistência em saúde no Brasil e menciona o sistema de saúde brasiliense como parte de um projeto ideológico que ofereceu espaço propício para a modernização, desenvolvimento e integração entre o ensino e serviço em saúde como uma marca dinâmica da transformação da educação médica gestada pelo Estado e que seria benéfica não apenas para o serviço público assistencial nacional, mas 
também para o serviço privado. Isso dá a entender que a proposta de criação da Escola Superior de Ciências da Saúde (ESCS) não era exclusivamente política, mas também voltava-se ao bem maior do desenvolvimento socioeconômico da sociedade brasileira através da superação dos modelos tradicionais de ensino e através da iniciativa e execução de outro modelo de ensino em saúde alternativo aos modelos tradicionais. A renovação do ensino médico se tornava pauta na reformulação da própria ideologia de crescimento da nação. A Universidade de Brasília (UNB), que já tinha seu planos pedagógicos estruturais consolidados, não teria oferecido abertura ou maleabilidade suficiente para instaurar o modelo pedagógico diferenciado que se propunha juntamente com a Secretaria de Estado de Saúde (SES-DF) e optou-se, nesse contexto, por criar-se uma instituição pública inédita de ensino em medicina e vinculada diretamente ao Estado ao invés de insistir no vínculo que se tentou estabelecer entre o a gestão da saúde pública local e a UNB.

Na perspectiva atual dos interlocutores da pesquisa, a UNB, à época de Darcy Ribeiro, tentou tomar uma posição de resistência às práticas educacionais tradicionalistas que vinham avançando conforme o Estado brasileiro afinava seus métodos de controle sobre os diversos aspectos da formação médica no país. No entanto, os modelos alternativos que vinham tentando ser implantados pela UNB parecem ter sido suprimidos no período da ditadura e abandonados nos anos seguintes em meio ao inchaço do mercado de trabalho da medicina privada, ao desenvolvimento das tecnologias médicas e aos currículos disciplinares tradicionais baseados no modelo flexneriano de prática e educação médicas.

$\mathrm{Na}$ visão de um dos estudantes, os projetos educacionais diferentes do modelo disciplinar permaneceram, lhe parece, numa espécie de modo de espera até que num dado momento o contexto político, social e intelectual fossem oportunos para a colocação em prática desses novos projetos educacionais e, enfim, a ESCS pôde encontrar um ambiente político e ideológico propício para sua criação.

Não dá para falar da ESCS sem antes falar da UNB dos anos 60. Na época a UNB tinha um tino muito mais holista no que diz respeito à metodologia de ensino. Quando chegou a época da ditatura, a coisa toda do Relatório de Flexner, nos anos 40, voltou à tona tomou conta das instituições de ensino em medicina, com divisão do curso por disciplinas, com oitenta alunos por turma, etc. Então, com a ditadura, o modelo de holismo tido pela UNB foi perdido pela introdução dessas ideias do relatório, da medicina voltada pro mercado. A ESCS, busca resgatar esse modelo holista perdido pela UNB implantando o modelo de ensino em PBL que, no DF, tentou ser aplicado na Universidade Católica, mas que por forças da política e dos interesses pela ideia, foi projetado na FEPECS com a criação da ESCS. [...] Acontece que na época, o 
governo Roriz (governador), junto com Frejat (secretário de saúde), fez muita politicagem na relação entre a secretaria de saúde a FEPECS e a ESCS. A gestão interna e externa, do modo como estava sendo feita, atrapalhava a liberdade dos princípios que guiam todo o projeto metodológico da ESCS, que é a integração entre serviço e educação na formação dos profissionais com uma metodologia de ensino diferente. (Estudante de medicina da ESCS. Fala registrada no diário de campo, 13/11/2013)

As motivações sociais e políticas do projeto de criação da Escola Superior de Ciências da Saúde (ESCS) são traduzidas nas palavras desse estudante de modo que a história e a política são implicadas juntas na implantação do projeto da escola. A "politicagem" da qual o estudante fala está relacionada com as estruturas das subordinações que existem entre as instituições dessa rede local que historicamente se formou e do nível de autoridade dos sujeitos de poder político que movimentam os processos e tomam decisões institucionais em nome do Estado. No capítulo 3 discorro sobre esse aspecto "politiqueiro" dos processos institucionais. Para os objetivos da pesquisa, o tratamento etnográfico da questão dos jogos de poder em torno do projeto de criação da nova universidade UNISUS apresenta, com maior virtuosidade, as relações políticas interinstitucionais do que os documentos históricos que estruturaram este capítulo. Por enquanto, mantenho o foco no eixo de discussão histórica do processo de criação da Escola Superior de Ciências da Saúde (ESCS) para que a compreensão do momento institucional de transformação que foi acompanhado etnograficamente possa ser devidamente ancorada na perspectiva histórica apresentada.

Analisando o dossiê sobre a criação da Fundação de Ensino e Pesquisa em Ciências da Saúde (FEPECS) e da Escola Superior de Ciências da Saúde (ESCS), observa-se que muito das discussões nas reuniões do grupo de trabalho responsável pela criação dessas instituições girou em torno da construção e do acionamento de uma rede interinstitucional de cooperação ao redor do projeto. Na sessão seguinte exploro a questão desses elos interinstitucionais.

\section{CONVÊNIOS INSTITUCIONAIS}

A comissão de criação da nova escola logo viu que a criação da nova fundação "envolvia a seleção e treinamento dos recursos humanos, a escolha das unidades acadêmicas que servirão como base para a elaboração do currículo integrado que contemplará uma metodologia ativa" e a "realização de um seminário com o objetivo de uniformização dos princípios acadêmicos 
do grupo" (FEPECS, 2002, 211-3), conforme destaco essas sentenças das atas de reuniões dispostas no dossiê sobre a criação da FEPECS. Além desses objetivos, o presidente do grupo de trabalho, Paulo Kalume, à época secretário adjunto da Secretaria de Saúde do Distrito Federal (SES-DF), disse que os "aspectos administrativos, gerenciais, jurídicos, financeiros e técnico-operatórios deverão ser definidos ao longo dos trabalhos"; e fez-se menção aos cursos de medicina da Universidade de Londrina, de Marília como "novos modelos de formação médica" que "são exemplos a serem seguidos" e que estavam dispostos à assessorar tecnicamente a comissão nestas questões práticas.

A rede interinstitucional, além de ser local, tendo visto o vínculo da escola com a secretaria de saúde, era composta por uma série de convênios com outras instituições de ensino em ciências da saúde, elas foram: a Universidade de Brasília (UNB); a Universidade Estadual de Londrina (UEL); a Faculdade de Medicina de Marília (FAMEMA); a Universidade Federal de Roraima (UFRR); e o Centro Universitário de Brasília (UNICEUB). Além do termo de cooperação estabelecido com a Secretaria de Estado de Saúde do DF (SES-DF). Precisa-se ressaltar que nem todas estas instituições citadas foram contempladas por um contrato formal oficialmente reconhecido, como a Universidade de Brasília (UNB) e o Centro Universitário de Brasília (UNICEUB). Os membros dirigentes das faculdades de ciências da saúde da UNB e do UNICEUB formam membros do grupo de trabalho responsável pela criação da instituição em seus processos de discussão interna ao grupo de trabalho e assessoramento quanto ao que se fazia necessário tecnicamente para a implantação de um curso de medicina. As outras instituições de fora do Distrito Federal, isto é, a Universidade Estadual de Londrina (UEL), a Faculdade de Medicina de Marília (FAMEMA) e a Universidade Federal de Roraima (UFRR) foram responsáveis pela logística voltada ao suprimento e formação do corpo profissional e assessoria voltada às infra estruturas necessárias para a implantação do curso, como a capacitação dos primeiros docentes quanto à metodologia pedagógica a ser adotada e à lista das infraestruturas necessárias ao funcionamento de um curso de medicina.

Tão importante foram os convênios com estas outras instituições que, numa das placas de mármore no saguão de entrada da FEPECS, conforme pode-se ver na Foto 3, está a menção à celebração dos convênios A placa na Foto 3 expressa valores centrais à consolidação do projeto de criação da Escola Superior de Ciências da Saúde (ESCS) em Brasília por refletir a integração do projeto local com outros projetos educacionais. Os valores dispostos na placa se 
remetem à ideia de integração nacional através da associação entre instituições no país que objetivem o desenvolvimento de projetos educacionais voltados à formação profissional em saúde, e evoca o fato de que a criação da ESCS em Brasília estava inserida em redes de relações institucionais e isso faz dela uma iniciativa que não é isolada de outras expressões de inovação do ensino em medicina que se expressavam pelo país.

Analisando o texto da placa na Foto 3, "integração administrativa" era a categoria de ordenamento principal para atingir os objetivos da nova instituição e, por analogia, das políticas públicas voltadas à saúde. Isso corrobora a ideia de consolidação de redes interinstitucionais regidas pelas políticas públicas voltadas para a educação em medicina no país. A Universidade Estadual de Londrina (UEL) se encarregou de fazer uma consultoria referente ao processo de capacitação docente e a Faculdade de Medicina de Marília (FAMEMA) ficou encarregada de fazer toda a consultoria logística e gerou um relatório para a implementação do curso no que se refere aos setores de informática, dos laboratórios morfofuncionais, da biblioteca e da infraestrutura física e administrativa. A Universidade Estadual de Londrina (UEL), conforme as atas das reuniões da comissão de criação da FEPECS também ficou responsável pelo estabelecimento dos critérios para a seleção dos docentes e realizou um "Curso de Introdução à Capacitação Docente" para os membros da comissão e para todos aqueles docentes que fossem contratados. A capacitação docente teria sido feita através de um curso com duração de uma semana proferido por profissionais da Universidade Estadual de Londrina (UEL).

Além do lado administrativo, a ideia de "integração ensino-assistência na área de ciências da saúde e pesquisa" conferia a base fundamental do projeto político-pedagógico da Escola Superior de Ciências da Saúde (ESCS). Ainda, a placa diz que "chegou-se à organização da proposta inovadora e holística que o curso de medicina da Escola Superior de Ciências da Saúde da Secretaria de Estado de Saúde do Distrito Federal" e aí pode-se ver que as características da "inovação" e "holismo" vieram estreitamente vinculadas ao caráter “integrador” que qualificava o projeto da escola tanto a nível de gestão administrativa quanto à nível pedagógico e ideológico que veiculava. 


\section{Foto 3:}

Placa de mármore preto e fontes douradas com a celebração dos convênios interinstitucionais à época da criação da FEPECS dispostas na portaria da instituição.

Dimensões: 1,5 x $2,5 \mathrm{~m}$.

DOIS CONVENIOS DE COLABORAÇĀO MÚTUA FORAM CELEBRADOS ENTRE A SECRETARIA DE ESTADO DE SAÓDE DO DISTRITO FEDERAL, A FUNDAÇĀO DE ENSINO SUPERIOR DE MARILIA-SP, A FACULDADE DE MEDICINA DE MARILIASP/FAMEMA E A FUNDACĀO DE APOIO AO DESENVOLVIMENTO TECNOLÓGICO DO HOSPITAL UNIVERSITARIO REGIONAL DO NORTE DO PARANÁ-HUTEC, ESTA PERIECENTE AO CENTRO DE CIENCIAS DA SAÚDE DA UNIVERSIDADE ESTADUAL DE LONDRINA/CCS/UEL.

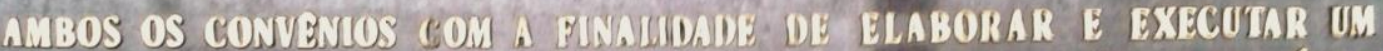
PLANO DE INTEOBACAD ADMDNISTRATIVA, DE ENSINO-ASSISTENCIA NA AREA DE CIENCLAS DE SAODE E PESOUISA, COM VISTAS AOI DESENVOLVIMENTO IECNICO-CIENTIFICO, MEDIANTE ATIVIDADE DE GRADUACAO, POS-GRADUACTO, RECICLAGEM, EDUCAÇÃO CONTINUADA E CONSULTORIAS.

UTILILANDO-SE TODOS OS RECURSOS DOS PARTICIPES CHEGOU SE A ORGANIZAÇ̄̃O DA PROPOSTA INOVADORA E HOLISTICA, QUE É 0 CURSO DE MEDICINA DA ESCOLA SUPERIOR DE CIENCIAS DA SAÚDE DA SECRETARIA D ESTADO DE SAUUDE DO DISTRITO FEDERAL, SENDO OS REPRESENTANTES DAS DUAS INSTITUICOOES NO GRUPO DE TRABALHO, CRI DO PELA S S/DF:

JOÄO JOSÉ BATISTA DE CAMPOS

VI E-COORDENADOR DO COLEGIADO DO CURSO DE MEDICINA $/ U$ LLONDRINA PA A

ROBERTO DE QUEIROZ PADILHA

DIRETOR GER L DA FA ULDADE DE MEDI 1 DE MARILIA / FAMEMA SATO PAU 0 
A noção de integração ia além apenas da composição unívoca de um sistema de saúde nacional único à nível da administração política e estatal, apesar de descentralizado em uma ampla rede interinstitucional pelas instâncias de governo da federação. O Projeto da ESCS tratava de integrar mais coisas em vários níveis. A integração se dava entre ensino e serviço de saúde; se dava entre instituições que acionam redes cooperativas de convênios; e se dava, acima de tudo, entre a ideologia de um projeto de crescimento e desenvolvimento da gestão política da educação em saúde no Brasil e a criação de instituições de ensino em medicina que desafiassem os modelos tradicionais de ensino em prol da formação de profissionais da saúde com perfil novo. Tais níveis da ideia-chave de integração perpassavam todo o projeto de criação da Escola Superior de Ciências da Saúde (ESCS) em Brasília e atualizavam política e ideologicamente os valores de um processo amplo de transformação dos modelos tradicionais de ensino em medicina historicamente desenvolvidos no país em consonância com as diretrizes democráticas de construção e consolidação de um projeto de nação maduro politicamente no que diz respeito aos preceitos ideológicos a que a gestão da saúde nacional e a formação de novos profissionais para atuarem no Sistema Única de Saúde (SUS).

Quanto aos princípios pedagógicos e finalidades sociais da instituição, os documentos trazidos pelo dossiê de criação da ESCS pareciam transparecer que houve, em geral, consonância entre os membros do grupo responsável pela criação da instituição quanto aos preceitos pedagógicos novos que buscava-se implementar. Mas houve entraves e discordâncias no projeto quanto aos espaços previstos para a realização das atividades pedagógicas dentro das unidades do sistema local de assistência. Isso aparece em uma das atas de reunião do grupo de trabalho de criação da escola:

Houve uma reunião com representantes da Secretaria de Estado de Saúde -SES- DF e
do Grupo de Trabalho, com vistas a definição da área de ensino na rede de saúde.
Participaram dessa reunião o representantes da Diretoria de Vigilância
Epidemiológica, Laboratório Central- LACEN, Diretoria de Estratégia de Saúde da
Família, Programa de Saúde da Família- PSF, Diretoria de Vigilância Sanitária,
Diretoria de Vigilância Ambiental, Diretoria de Promoção de Assistência à Saúde e
representantes do CEDRHUS. O grupo concluiu que a reunião não atingiu o objetivo
pretendido, visto que foram constatadas diferenças de posicionamentos quanto à
receptividade da proposta. (FEPECS, 2002, 256)

A gestão da saúde haveria de interagir junto à gestão da nova Escola e isso era, e ainda o é, um desafio para o modelo de gestão pública existente. Não há nada nos dossiês que dê detalhes à referida "diferença de posicionamentos quanto à receptividade da proposta". Contudo, o fato de a instituição ter registrado a tensão esboça que o termo de cooperação 
oficializado entre a nova instituição de ensino, isto é, a Escola Superior de Ciências da Saúde (ESCS) e a Secretaria de Estado e Saúde do DF (SES-DF), se deu de forma conflituosa e com alguns desentendimentos quanto à proposta pedagógica da nova Escola; ainda que os documentos não esclareçam do que se trataram tais tensões. Por ser uma novidade, a ideia de que os estudantes estariam presentes participando das atividades cotidianas das unidades de saúde, as equipes da Secretaria de Estado de Saúde do Distrito Federal (SES-DF) relutaram quanto à tal característica. A ideia de uma escola de medicina vinculada à Secretaria de Saúde era novidade e a própria Secretaria estranhou a proposta inicialmente talvez pela falta de conhecimento quanto ao modo de funcionamento da nova escola de medicina existindo dentro do sistema público de saúde ou por qualquer outra questão relacionada às estruturas institucionais, hierárquicas e às relações políticas travadas.

Analisando o contexto de criação da Escola Superior de Ciências da Saúde (ESCS) no que diz respeito à gestão do sistema de educação local, pelo ponto de vista dos gestores das instâncias administrativas da educação pública na época, observa-se que uma segunda comissão interna à Secretaria de Educação do Distrito Federal (SE-DF) foi criada pelo próprio governo para analisar e avaliar das condições necessárias para o credenciamento da instituição de ensino superior na oficialidade da norma. Traz-se um trecho do próprio documento de credenciamento do curso de medicina, que diz o seguinte:

Frente às correntes que ajuízam que já há profissionais em número suficiente, nesta
ou naquela área, numa velada ou explícita defesa da reserva de mercado, é preciso
afirmar que a oferta de ensino superior aos jovens é uma questão de cidadania e não
de mercado. A educação não pode ser prisioneira das conveniências do mercado, nem
do corporativismo profissional. O que fundamenta o direito à formação profissional e
à sua livre escolha é a cidadania, entendida como autonomia e emancipação. (CEDF,
2001, 128)

O Conselho de Educação do Distrito Federal (CSDF) anunciou que existia a noção de que no mercado de trabalho médico já existiam profissionais "suficientes", quando sabe-se que o mercado de trabalho do serviço público tem absorvido muitos profissionais da saúde através dos concursos públicos. Já a Fundação de Ensino e Pesquisa em Ciências da Saúde (FEPECS) coloca: "no que diz respeito à contemporaneidade da educação médica [...] a proposta é transformadora e revela uma visão de futuro" (FEPECS, 2002, 133). A Secretaria de Educação (SE-DF) enxergou a proposta como engenhosa e reveladora da "coerência entre a filosofia do curso, a proposta pedagógica e a estratégia do fazer" (FEPECS, 2002, 120), o reconhecimento de um processo de transformação mais amplo quanto à formação médica segundo a própria 
instituição era que a "iniciativa da ESCS representa para o Distrito Federal uma mudança de paradigma em educação em saúde, dando um passo adiante em sintonia com os movimentos sociais nacionais e internacionais de renovação da formação médica.” (FEPECS, 2002, 133).

A criação da Escola Superior de Ciência da Saúde (ESCS), portanto, foi vista em suas relações com o mercado de trabalho como provedora de mais médicos para atuarem no mercado de trabalho da saúde pública e colocada como contributiva da consolidação de uma proposta de ensino que refletia os princípios maiores do crescimento e desenvolvimento da saúde brasileira através de um projeto com base em valores que revigoravam a ideia de "integração", "renovação" e "inovação" dos modelos de ensino em saúde oferecidos pelo Estado e dos modelos de gestão política dos projetos públicos e seus processos.

\title{
PEDAGOGIA DOS PROBLEMAS
}

Para se ter a visão da própria que a Escola Superior de Ciências da Saúde (ESCS) faz de si dentro do contexto mais amplo de renovação do ensino médico no contexto da saúde pública brasileira, trago a fala proferida pelo coordenador do curso de graduação em medicina da ESCS feita na ocasião da solenidade de comemoração dos 12 anos de funcionamento da Escola, no final de 2013. Por ser uma ocasião solene de comemoração de aniversário da escola, a natureza dos discursos puderam evidenciar os valores trazidos pela proposta da escola como uma forma de reafirmar a relação que a escola tinha com as questões do Estado e do sistema público de saúde nacional.

\begin{abstract}
A ESCS é uma escola diferente primeiro pelo vínculo que tem com a Secretaria de Saúde e por ser a primeira escola no Centro-Oeste e a terceira no Brasil que utiliza a metodologia PBL [Problem Based Learning] e isso proporciona qualidade profissional excelente para quem estuda e trabalha nesta escola. [...] A educação na ESCS está perto dos problemas enfrentados pelo sistema público de saúde tendo esta tensão como a base do sistema de ensino da escola. Isso é o que rompe os paradigmas porque aqui se contratam docentes apenas da secretaria de saúde e só da secretaria de saúde, então o ensino vem do e para o SUS e não das academias tradicionais de medicina, o que insere o estudante precocemente no mundo do trabalho. (Coordenador do curso de graduação em medicina da ESCS. Fala registrada no diário de campo, 13/11/2013)
\end{abstract}

A fala do coordenador faz menção ao diferencial da gestão da Escola ligando a proposta pedagógica ao mercado de trabalho médico fazendo elogios à proximidade da escola com a realidade da saúde da população do Distrito Federal. A ideia de "rompimento de paradigmas" 
se constrói sobre o vínculo que a escola tem com a gestão da saúde local e na implementação do projeto pedagógico. Então, o que significa na visão dos membros da ESCS “estar perto dos problemas enfrentados pelo sistema público de saúde"? Em quais instâncias é possível localizar essa "tensão" primordial que é tida como a base do sistema de ensino da escola? Para responder a tais questionamentos uma análise do projeto pedagógico da escola foi necessária.

A principal metodologia pedagógica adotadas pela Escola Superior de Ciências da Saúde (ESCS) é a da Aprendizagem Baseada em Problemas (ABP). Existem controvérsias sobre a exata origem dessa metodologia. Existem referencias bibliográficas (Siqueira-Batista, 2009, 2013) que indicam que tal metodologia surgiu na década de 1960 na universidade holandesa de Maastricht e existem bibliografias (Gonçalves, 2002) que dizem que a metodologia é proveniente da universidade canadense de McMaster. Para a Escola Superior de Ciências da Saúde (ESCS) a versão oficial dessa origem é a holandesa. A origem exata da gênese da metodologia não é tão importante, pois não se busca aqui refazer a trajetória histórica dessa metodologia pedagógica na medida que foi sendo adotada por instituições de ensino em medicina no Brasil e no mundo. Basta ter em mente a noção de que ela faz parte do processo transformação do ensino em medicina que veio à tona durante as décadas de 1970 e 1980 , havendo várias adaptações desse modelo de ensino e aprendizagem por algumas universidades e faculdades de medicina na Argentina, Austrália, Canadá, Estados Unidos, Grã-Bretanha, Indonésia, Malásia, México, Suécia, Suíça, e como não, no Brasil (Gonçalves, 2002). No Brasil a metodologia ABP veio a ter expressão maior nas décadas de 1980 e 1990. (Siqueira-Batista, 2009; Batista e Gonçalves, 2011). A Universidade Estadual de Londrina (UEL) em 1998 e a Faculdade de Medicina de Marília (FAMEMA) em 1997 foram pioneiras na aplicação desta metodologia em cursos de medicina segundo o ponto de vista dos interlocutores na pesquisa. As universidades de Roraima (UFRR), de Santa Cruz e Ilhéus na Bahia também foram umas das primeiras também, durante os anos 2000. (Gonçalves, 2002) Em Teresópolis, no Rio de Janeiro, o Centro Universitário Serra dos Órgãos (UNIFESO) também passou a adotar a metodologia em 2005 (Siqueira-Batista, 2009). E, enfim, a metodologia foi adotada pela Escola Superior de Ciências da Saúde (ESCS) em Brasília, no ano de 2001.

Foi possível saber, a partir de pesquisas bibliográficas sobre a metodologia da Aprendizagem Baseada em Problemas (ABP) que, pela natureza dos artigos acadêmicos publicados nas plataformas de pesquisa da Scielo, Capes e Lilacs, essa metodologia pedagógica 
foi inicialmente usada no Brasil com mais ênfase em cursos de engenharia. Para dar recorte mais definido à estrutura argumentativa, selecionei aqueles artigos que traziam informações que possibilitassem alguma compreensão do sentido da adoção da metodologia da Aprendizagem Baseada em Problemas (ABP) no contexto das mudanças e transformações quanto aos tipos de metodologias de ensino adotadas nos cursos de medicina e áreas da saúde.

Na Reforma Sanitária durante os anos 1990 e com as subsequentes reestruturações políticas e democráticas pelas quais passaram os projetos federais voltados para a assistência em saúde no Brasil, segundo Siqueira-Batista (2009), a metodologia de ensino ABP veio a ser adotada como uma forma de resistência aos currículos tradicionais de medicina através de uma reflexão acerca das práticas e saberes médicos no que diz respeito às pedagogias utilizadas para formar profissionais. Buscavam-se estruturas que fossem mais capazes de responder às necessidades da população e implicassem na articulação de ordenamentos institucionais e educacionais inseridos numa ordenação moral e ideológica que ampliava as perspectivas da formação médica no Brasil.

Segundo Siqueira-Batista (2009) o método da Aprendizagem Baseada em Problemas (ABP) deve acontecer em um movimento de continuidade e ruptura. Os estudantes devem relacionar os conteúdos apreendidos durante as atividades tutoriais aos conhecimentos prévios que construíram anteriormente. O processo de ruptura, segundo o autor, deve acontecer quando novos desafios são colocados em jogo durante as atividades, surtindo uma tensão que abre espaço e contexto férteis para ampliar a possibilidade de construção de novos conhecimentos. A complexidade e dificuldade dos problemas vão aumentando na medida em que o curso vai avançando. Entre um processo de continuidade, no qual os conhecimentos prévios são encadeados em um processo que é cumulativo ao longo do curso, e um processo de ruptura, quando novos conhecimentos são suscitados, há um movimento que é de natureza espiralada e, na medida em que novos problemas são colocados, o nível do desafio aumenta e ergue o patamar do processo de aprendizagem para a proposição de novos problemas mais complexos e que exigem mais esforço de estudo por parte tanto dos estudantes quanto dos professores.

Para sustentar essa tensão repleta de continuidades e rupturas, a estrutura curricular do curso de medicina da Escola Superior de Ciências da Saúde (ESCS) tem um currículo que é tanto vertical quanto horizontal. Cada eixo curricular se relaciona a um grupo de atividades pedagógicas especificas tanto práticas quanto teóricas e podem acontecer tanto nas unidades de 
atendimento do sistema público de saúde quanto nas dependências da escola, nas salas de aula e laboratórios. Entretanto, não há uma separação nítida entre teoria e prática distinguível entre esses espaços. Teoria e prática acontecem num esquema de continuidades e rupturas no qual as duas se misturam em processos de atividades paralelas e sobrepostas umas às outras. As atividades e problemas realizados em cada Módulo Temático (MOD) se relacionam com os outros dois eixos pedagógicos principais, que são os de Habilidades e Atitudes (HA) e o de Interação Ensino-Serviço-Comunidade (IESC). Aí se vê a prática pedagógica integradora e interdisciplinar. Na Figura 2 é possível ver a composição do currículo do curso de medicina da ESCS.

Por exemplo, no "Módulo 102", que tem o título de "concepção e formação do ser humano", um dos conteúdos gerais trata do "desenvolvimento embrionário e fetal” (ESCS, 2001, 98). Ao mesmo tempo em que os estudantes se reúnem nos grupos tutoriais e cursam cada Módulo Temático, concomitantemente, no eixo de Habilidades e Atitudes os estudantes fazem atividades em laboratórios de anatomia e morfologia humanas, no eixo de Interação Ensino-Serviço-Comunidade, eles irão realizar atividades nas unidades de atendimento especializados em ginecologia e obstetrícia. Ou: No "módulo 401", oferecido no quarto ano, e tem o título de "locomoção", um dos conteúdos trata do "funcionamento do aparelho locomotor em movimento" (ESCS, 2001, 119); concomitantemente os estudantes realizam atividades nos laboratórios da escola no eixo de Habilidades e Atitudes e no eixo de Interação Ensino-ServiçoComunidade os estudantes frequentam clínicas de ortopedia nas unidades de atendimento do sistema público de saúde.

O eixo pedagógico de Interação Ensino-Serviço-Comunidade, ou "IESC", para usar os termos que os interlocutores na pesquisa usavam, é o eixo curricular que recebeu maior atenção e esforço etnográfico durante a pesquisa porque nele se localiza a parte do curso que mais se relaciona com temas ligados às políticas de saúde nacional, principalmente no que diz respeito à sua vinculação com as políticas de atenção básica. 


\begin{tabular}{|c|c|c|c|c|}
\hline \multicolumn{5}{|c|}{$\begin{array}{l}\text { Figura 2: } \\
\text { Fluxo curricular do curso de medicina da ESCS. } \\
\text { Fonte: Projeto Político Pedagógico, } 2001 .\end{array}$} \\
\hline Série & $\mathbf{N}^{0}$ Semanas & Código & Nome Do Módulo & C.H. \\
\hline $1^{\mathrm{a}}$ & 3 & MOD101 & Introdução ao Estudo da Medicina & 90 \\
\hline $1^{\mathrm{a}}$ & 6 & MOD102 & Concepção e Formação do Ser Humano & 180 \\
\hline $1^{\mathrm{a}}$ & 6 & MOD103 & Metabolismo & 180 \\
\hline $1^{\mathrm{a}}$ & 5 & MOD104 & Funções Biológicas I & 150 \\
\hline $1^{\mathrm{a}}$ & 5 & MOD108 & Funções Biológicas II & 150 \\
\hline $1^{\mathrm{a}}$ & 4 & MOD105 & Atualização Ia e Ib (eletiva) & 80 \\
\hline $1^{\mathrm{a}}$ & 6 & MOD106 & Mecanismos de Agressão e Defesa & 180 \\
\hline $1^{\mathrm{a}}$ & 4 & MOD107 & Abrangência das Ações de Saúde & 120 \\
\hline $1^{\mathrm{a}}$ & 35 & IESC101 & Interação Ensino-Serviços-Comunidade I & 140 \\
\hline $1^{\mathrm{a}}$ & 35 & HA101 & Habilidades e Atitudes & 210 \\
\hline \multicolumn{4}{|c|}{ Carga Horária Total $1^{\mathrm{a}}$ série } & 1.480 \\
\hline $2^{\mathrm{a}}$ & 5 & MOD201 & Nascimento, Crescimento e Desenvolvimento & 150 \\
\hline $2^{\mathrm{a}}$ & 6 & MOD202 & Percepção, Consciência e Emoção & 180 \\
\hline $2^{\mathrm{a}}$ & 6 & MOD203 & Processo de Envelhecimento & 180 \\
\hline $2^{\mathrm{a}}$ & 6 & MOD204 & Proliferação Celular & 180 \\
\hline $2^{\mathrm{a}}$ & 4 & MOD205 & Atualização IIa e Iib (eletiva) & 80 \\
\hline $2^{\mathrm{a}}$ & 7 & MOD206 & Saúde da Mulher, Sexualidade e Planejamento Familiar & 210 \\
\hline $2^{\mathrm{a}}$ & 6 & MOD207 & Locomoção e Preensão & 180 \\
\hline $2^{\mathrm{a}}$ & 36 & IESC202 & Interação Ensino-Serviços-Comunidade II & 144 \\
\hline $2^{\mathrm{a}}$ & 36 & HA202 & Habilidades e Atitudes & 216 \\
\hline \multicolumn{4}{|c|}{ Carga Horária Total $2^{\mathrm{a}}$ série } & 1.520 \\
\hline $3^{\mathrm{a}}$ & 6 & MOD301 & Dor & 180 \\
\hline $3^{\mathrm{a}}$ & 7 & MOD302 & Dor Abdominal, Diarréia, Vômitos e Icterícia & 210 \\
\hline $3^{\mathrm{a}}$ & 6 & MOD303 & Febre, Inflamação e Infecção & 180 \\
\hline $3^{\mathrm{a}}$ & 5 & MOD304 & Doenças Resultantes da Agressão ao Meio Ambiente & 150 \\
\hline $3^{\mathrm{a}}$ & 4 & MOD305 & Atualização IIIa e IIIb (eletiva) & 80 \\
\hline $3^{\mathrm{a}}$ & 6 & MOD306 & Perda de Sangue & 180 \\
\hline $3^{\mathrm{a}}$ & 5 & MOD307 & Fadiga, Perda de Peso e Anemias & 150 \\
\hline $3^{\mathrm{a}}$ & 36 & IESC303 & Interação Ensino-Serviços-Comunidade III & 144 \\
\hline $3^{\mathrm{a}}$ & 36 & HA303 & Habilidades e Atitudes & 216 \\
\hline \multicolumn{4}{|c|}{ Carga Horária Total $3^{\mathrm{a}}$ série } & 1.490 \\
\hline $4^{\mathrm{a}}$ & 6 & MOD401 & Transtornos Mentais e de Comportamento & 144 \\
\hline $4^{\mathrm{a}}$ & 6 & MOD402 & Distúrbios Sensoriais, Motores e da Consciência & 144 \\
\hline $4^{\mathrm{a}}$ & 7 & MOD403 & Dispnéia, Dor torácica e Edemas & 168 \\
\hline $4^{\mathrm{a}}$ & 5 & MOD404 & Desordens Nutricionais e Metabólicas & 120 \\
\hline $4^{\mathrm{a}}$ & 4 & MOD405 & Atualização IVa e IVb (eletiva) & 80 \\
\hline $4^{\mathrm{a}}$ & 5 & MOD406 & Manifestações Externas das Doenças e Iatrogenias & 120 \\
\hline $4^{\mathrm{a}}$ & 7 & MOD407 & Emergências & 168 \\
\hline $4^{\mathrm{a}}$ & 36 & IESC404 & Interação Ensino-Serviços-Comunidade IV/Hab. e Atitudes & 576 \\
\hline \multicolumn{4}{|c|}{ Carga Horária Total $4^{\mathrm{a}}$ série } & 1.520 \\
\hline $5^{\mathrm{a}}$ & 12 & IM501 & Saúde do Adulto I - Clínica Médica (Estágio) & 480 \\
\hline $5^{\mathrm{a}}$ & 12 & IM502 & Saúde do Adulto I - Clínica Cirúrgica (Estágio) & 480 \\
\hline $5^{\mathrm{a}}$ & 12 & IM503 & Saúde da Criança I (Estágio) & 480 \\
\hline $5^{\mathrm{a}}$ & 12 & IM504 & Saúde da Mulher I (Estágio) & 480 \\
\hline $5^{\mathrm{a}}$ & 48 & IM505 & Saúde Coletiva I (Estágio) & 192 \\
\hline \multicolumn{4}{|c|}{ Carga Horária Total $5^{\mathrm{a}}$ série } & 2.112 \\
\hline $6^{\mathrm{a}}$ & 8 & IM601 & Saúde do Adulto II -Clínica Médica (Estágio) & 320 \\
\hline $6^{\mathrm{a}}$ & 8 & IM602 & Saúde do Adulto II - Clínica Cirúrgica (Estágio) & 320 \\
\hline $6^{\mathrm{a}}$ & 8 & IM603 & Saúde da Criança II (Estágio) & 320 \\
\hline $6^{\mathrm{a}}$ & 8 & IM604 & Saúde da Mulher II (Estágio) & 320 \\
\hline $6^{\mathrm{a}}$ & 8 & IM605 & Saúde Coletiva II (Estágio) & 320 \\
\hline $6^{\mathrm{a}}$ & 4 & IM606 & Estágio Eletivo & 160 \\
\hline \multicolumn{4}{|c|}{ Carga Horária Total $6^{a}$ série } & 1.760 \\
\hline \multicolumn{4}{|c|}{ Carga Horária Total Geral } & 9.882 \\
\hline
\end{tabular}


É no módulo de IESC que se localiza o ponto fulcral da "interação" entre ensino e serviço, ou seja, entre processos pedagógicos e processos de trabalho, que é a inovação maior que a proposta pedagógica da Escola Superior de Ciências da Saúde (ESCS) traz e por isso pode ser considerada a parte do currículo mais inovadora pelo vínculo direto e corrente que tem com as atividades da saúde preventiva e da atenção básica, mote das políticas nacionais de saúde nos últimos anos e que se reflete no tipo ideal de profissional que a escola busca formar.

\section{INOVADORA INTERAÇÃO ENSINO-SERVIÇO-COMUNIDADE}

A construção do conhecimento através da interação ensino-serviço, na lógica da proposta do projeto pedagógico, visa a construção de um perfil profissional em que os sujeitos de seus processos de aprendizagem sejam capazes de "empregar o método científico e o trabalho em equipe nas tarefas de assistência" (ESCS, 2001, 68); adquirir "respeito aos pacientes e colegas, que compreenderá, sem preconceitos, a diversidade de bases culturais e a igualdade" (ESCS, 2001, 71); e finalmente "atuar no sistema de saúde" (ESCS, 2001, 87). Segundo a visão de uma professora enquanto falava sobre o método pedagógico da escola, o eixo de IESC visa a inserção dos estudantes em atividades pedagógicas realizadas pela escola em cidades da periferia de Brasília com o objetivo de "problematizar a realidade do atendimento púbico de saúde na atenção básica". Percebe-se a interface e imbricação concisa entre o universo da prática pedagógica das atividades frente o universo dos serviços públicos de saúde pública na prática.

Segundo o documento do Projeto Pedagógico da ESCS, o eixo de Interação EnsinoServiço-Comunidade (IESC)

[...] é uma unidade educacional que tem como diretriz o desenvolvimento de atividades de aprendizagem vinculada à realidade da saúde da população, envolvendo ações de promoção de saúde, prevenção, cura das doenças e recuperação da saúde, em equipe multidisciplinar. Tem como propósito contribuir para a formação de profissionais da saúde visando torna-los comprometidos com a saúde da comunidade [...] com base num novo modelo de atenção em saúde, com enfoque na família, e tal como visa: promover um contato precoce com a realidade de saúde; identificar os principais problemas de saúde da população; atuar no sistema de saúde mediante ações [...]; realizar a integração ensino, pesquisa e extensão. [...] Os campos de atuação são os ambientes comunitários, as equipes do Programa Saúde da Família, os serviços de primeiro nível de atenção à saúde (centros e postos de saúde), de segundo nível (hospitais regionais e serviços especializados) e de terceiro nível (Hospital de Base). (ESCS, 2001, 86-7. Grifos meus.) 
A ideia e prática de uma formação "vinculada à realidade" é um dos principais trunfos disponíveis nas falas daqueles que fazem parte da Escola Superior de Ciências da Saúde (ESCS) e se torna mais significativa pelo vínculo específico com o modelo de atenção em saúde "com enfoque na família”, isto é, na atenção básica. E ainda, pela característica multidisciplinar e integradora dos conteúdos e metodologias de ensino e aprendizagem que colocam os estudantes em contato com a realidade do sistema público de saúde, no entanto, conforme mostro adiante, a forma com que os processos pedagógicos e institucionais são construídos na prática é questionada pelos estudantes.

Tive a oportunidade de acompanhar as atividades de uma turma do primeiro ano por duas semanas à atividades do eixo de Interação Ensino-Serviço-Comunidade, o IESC. Fui duas vezes com estes estudantes à duas vilas próximas à cidade de Sobradinho, cidade localizada a mais ou menos 20 quilômetros de Brasília. Uma dessas atividades foi realizada na vila Dnocs, que fica muito próxima à cidade de Sobradinho, separadas por uma rodovia, apenas. As atividades se iniciaram por volta das oito e meia da manhã e o grupo se reuniu numa sala cedida por uma igreja, que oferecia uma sala de seu espaço para as atividades da escola. Na vila Dnocs não existia, na época do trabalho de campo, alguma unidade de saúde do governo como um posto de saúde ou unidade de pronto atendimento. Para a escola realizar as atividades do módulo Interação Ensino-Serviço-Comunidade (IESC) em determinados locais ela precisava acionar outras organizações estruturadas presentes nesses locais para que os estudantes e professores se reúnam e façam o trabalho pedagógico. Foram 17 pessoas ao total nesta atividade, entre estudantes, o professor, três agentes comunitários de saúde, uma enfermeira e uma médica da vila.

Os agentes comunitários de saúde são profissionais que atuam na atenção básica e realizam trabalhos voltados ao Programa Saúde da Família (PSF), qual faz parte do amplo espectro de políticas públicas federais voltadas para a saúde da população através da prevenção e monitoramento domiciliar de questões relativas à saúde das famílias com enfoque que se afasta de abordagem clínica para uma abordagem coletiva e epidemiológica. Os agentes comunitários de saúde visitam as famílias de uma determinada região fazendo um controle fiscalizador da saúde das pessoas das famílias o que eles dizem "prevenir as pessoas de chegarem ao ponto de ter que ir pro hospital". Os estudantes acompanham o trabalho dos agentes de saúde visitando famílias e entrevistando os membros de cada uma na região, ou 
"cenário", como é dito cotidianamente entre os estudantes e professores, e essas atividades são parte do processo de aprendizagem e da elaboração de estudos, pesquisas e montagem de portfólios que servem como formas de avaliação dos estudantes e formação na atenção básica.

$\mathrm{Na}$ ocasião dessa atividade de Interação Ensino-Serviço-Comunidade (IESC) o professor mostrou slides num projetor portátil que ele mesmo carregou com quadros e dados referentes à pesquisa que os estudantes já vinham fazendo na vila Dnocs e numa outra vila, a Basevi, perto dali. Os estudantes estavam fazendo uma pesquisa cujo objetivo era realizar uma comparação entre uma amostra das fichas de cadastro da família ${ }^{4}$ da vila Basevi e uma amostra das fichas do Dnocs, pelas quais estavam buscando traçar o "risco-familiar" nestes locais num projeto de pesquisa que se vinculasse a estratégia de saúde da família, o PSF, Programa Saúde da Família. Do que tratam essas fichas? Os agentes comunitários de saúde tinham cada um uma pasta com fichas de cada família com dados como o número de membros na família, quantos estão doentes, quantos tem hábitos que ofereçam algum risco de saúde para a família. Alguns dados para a pesquisa e atividade dos estudantes estavam sendo obtidas a partir dessas fichas, por isso entra-se em detalhes sobre elas.

O professor sugeriu que as fichas de cadastro das famílias, em posse dos agentes comunitários de saúde, sofressem algumas alterações quanto à coleta dos dados para a atividade dos estudantes. As fichas de cadastro da família traziam dados que poderiam, segundo o professor, ser desmembrados em dados mais detalhados e sugeriu novas classificações para os dados nas fichas, tal como a categoria de drogadição, por exemplo, que segundo ele, e os estudantes concordaram, poderia ser subdividida em alcoolismo, tabagismo e outras drogas, o que colocaria riscos diferentes à realidade de saúde daquela família. Ou ainda, por exemplo, a presença de pessoas com mais de 60 anos, ou de gestantes, crianças menores do que um ano de idade; ou então, dividindo problemas psiquiátricos de neurológicos, dizendo estes serem problemas de diferentes naturezas do ponto de vista da classificação médica. Cada um desses dados seriam obtidos através das fichas dos agentes, as quais estavam em pastas em posse dos próprios agentes. A atividade tinha cunho epidemiológico com vistas à recortar-se uma amostra das fichas de cada família para que os estudantes soubessem como funciona o trabalho dos agentes comunitários de saúde; realizassem uma pesquisa que fazia parte das atividades

\footnotetext{
${ }^{4}$ Ver Anexo.
} 
programadas e que seria apresentado no congresso interno da escola que aconteceria dali alguns meses.

Num determinado momento o professor fez questão de deixar claro que os dados não seriam para título de "tratamento", e sim de "acompanhamento" familiar. Ao mesmo tempo, as mudanças de classificação dos dados, o professor fazia perguntas aos estudantes sobre conteúdos de atividades anteriores que diziam respeito à atividade que estavam fazendo na vila naquele dia. Uma estudante perguntou se, por exemplo, houvesse três diabéticos em uma família, se o risco não seria 3, ao invés de 1, por serem três pessoas com a doença. O professor então explicou que era para se pensar em "prioridade de visitas" e não em "número de doentes por família”, então o risco seria 1, uma vez que diabetes tinha risco 1 na tabela. Em seguida, um dos agentes de saúde explicou que mesmo tendo 3 doentes com a mesma doença em uma casa, ele teria que fazer apenas uma visita, e não três visitas àquela casa, segundo as diretrizes do seu trabalho como agente de saúde. Isso fez com que os estudantes entendessem melhor os objetivos da atividade e qual era a natureza do trabalho dos agentes de saúde.

Após a discussão sobre como fazer a leitura das fichas, o trabalho braçal de leitura e separação das fichas se iniciou. Cada agente comunitário tinha um número diferente de fichas, correspondentes tanto a área urbana do Dnocs quanto a área rural. Por conveniência o professor disse que seria melhor os estudantes ficarem apenas com as fichas da área urbana, pela facilidade que a turma teria de fazer visitas e pelo tempo disponível para as atividades, que duravam uma manhã por semana. Os estudantes acumularam todas as fichas de cada agente, contando somente a área urbana. Somaram umas 500 fichas. Retirou-se, aleatoriamente, $25 \%$ do montante que cada agente tinha como amostra, misturou-se os $25 \%$ de todas estas fichas e fez-se a contagem de pontos de risco em cada ficha para traçar uma média da amostra. Os agentes estavam com suas fichas em pastas com compartimentos plásticos, contendo as fichas separadas uma à uma por rua e endereço para facilitar o trabalho deles. Cada agente comunitário de saúde ficava responsável por uma série específica de fichas que corresponde às famílias que moram numa mesma área da vila. Quando o professor disse que os estudantes teriam que misturar todas para obter uma amostra o mais aleatória possível, todos os agentes de saúde respiraram fundo, meio desconcertados e ao mesmo tempo conformados com o fato de que teriam suas fichas retiradas da ordem e misturadas com as de seus colegas. As fichas de cada agente de saúde tiveram de ser identificadas uma a uma com uma marca no canto alto da ficha, 
para que não se misturassem as fichas entre cada agente de saúde, os quais ficam responsáveis por um determinado grupo de famílias em determinadas regiões da vila.

Em seguida, os estudantes foram separados em 4 grupos. O professor me alocou em um dos grupos e fiz a atividade junto com os estudantes. Eu os ajudei a marcar as fichas com o nome do agente de saúde que ficou em nosso grupo para que as fichas não terminassem mais embaralhadas ainda. O outros grupos marcaram as fichas com os nomes dos agentes comunitários de saúde que ficaram em seus grupos. Cada grupo ficou com um dos quatro agentes comunitários. Em média, cada grupo ficou com número de trinta à quarenta fichas para analisar e em um dado momento uma pequena confusão aconteceu. Primeiro era para identificar as fichas com o nome de cada agente e depois era para misturar todas as fichas. Um monte de mais ou menos 500 fichas começou a ser misturado por todos. Distribuiu-se montinhos a cada um para que todos misturassem as fichas ao mesmo tempo. Misturadas as fichas, era para separar e reorganizar as fichas por nome de cada agente comunitário de saúde para que estes pudessem acompanhar cada grupo, pois eles conheciam as famílias às quais as fichas correspondiam e o que ajudaria na obtenção de dados sobre as famílias, e também porque os agentes disseram que algumas fichas estavam desatualizadas. Reagruparam-se as fichas de cada agente, retirou-se aleatoriamente $25 \%$ de cada monte e recomeçamos a seleção das fichas. Eram muitas mãos mexendo em muitas fichas ao mesmo tempo. Houve um momento em que o monte de $25 \%$ das fichas de um dos agentes voltou o monte maior de fichas e foi misturado novamente com os outros montes de fichas. Todos ficaram confusos. As fichas todas haviam se embaralhado tanto para a finalidade da atividade, que era traçar uma amostra do "riscofamiliar" na vila quanto para a organização das fichas dos agentes em suas pastas aonde estavam organizadas as fichas, separadas por endereço.

Os agentes olhavam desolados para as fichas que eram carregadas pelos vários estudantes de um lado para o outro da pequena sala. O professor logo percebeu a confusão que estava acontecendo, interrompeu a atividade por um momento e pegou todas as fichas para reorganiza-las ele mesmo. Ele olhou para mim, em meio a todo o movimento e conversa na sala, pedindo para eu não me importar com a bagunça das fichas e que aquilo era "bom para a atividade". Depois que o professor fez a tarefa de separar as fichas, passamos todos cerca de quarenta minutos fazendo a leitura das fichas e somando o risco de cada família, conforme a atividade pedia. A amostra envolveu cerca de 80 fichas ao todo, somando todos os grupos. 
Somaram-se os números que cada grupo obteve e foram analisados pelo professor e pelos estudantes. O professor fez uma análise provisória, mostrando um gráfico que fez rapidamente e previu que existiam diferenças no risco familiar entre duas vilas, o que provocou muito a ele e aos estudantes, deixando-o satisfeitos e instigados com os resultados que viram, tendo em mente comparações às visitas que eles mesmos vinham fazendo a estas vilas. Feito tudo isso, devolveram-se as fichas, todas embaralhadas, para cada agente de saúde e a atividade se encerrou.

Todos nos despedimos e fomos embora. Voltamos eu mais dois estudantes de carona com o professor. No caminho de volta conversamos sobre a atividade e comentamos sobre a "bagunça" feita no trabalho com as fichas. O professor respondeu dizendo que foi bom isso. Um dos estudantes interrompeu dizendo que viu fichas muito desatualizadas, como que datas de nascimento de 2007, dizendo que a criança teria 3 anos de idade quando hoje ela estaria com 6 anos de idade. O professor disse que sabia que encontraríamos "trabalho mal feito" na ficha dos agentes comunitários de saúde e que achou bom revirarmos as fichas para que os agentes de saúde reorganizem as fichas, dizendo, na sua visão, que estávamos, na verdade, "fazendo um favor" para eles.

Pude perceber que os estudantes e professores são implicados em relações de poder com o sistema de saúde e com as pessoas que atuam dentro desse sistema durante as atividades pedagógicas. Na imbricação inescapável entre o grupo que compreende estudantes e professor e o grupo que compreende os agentes de saúde, triangulam-se relações de poder pelo fato da natureza da própria relação entre os processos de ensino que adentram mais os processos de trabalho do que o contrário. Isso cria uma esfera onde as ênfases dadas ao lado pedagógico são maiores do que as vicissitudes do processo de trabalho daqueles que atuam no serviço de saúde. Para compreender o sentido desse tipo de relação de poder na qual criou-se um patamar composto pela intersecção de dois grupos de pessoas que se encontraram contextualmente enquanto instituições, é preciso falar de coletividades institucionais de ordens e posições diferentes implicadas em um mesmo processo.

Colocadas em contato umas com as outras durante as atividades pedagógicas, o encontro dessas instituições, isto é, entre ESCS e SUS, cria-se um espaço de interação num patamar de sociabilidade face a face na qual determinadas condições para que a realização das atividades aconteçam de maneira estável. Pelo menos nesse caso observado, foi no espaço de interface e 
imbricação institucional que a instituição escolar adentrou muito mais no sistema de saúde do que o sistema de saúde adentrou a escola durante as práticas pedagógicas. Apesar de a Escola Superior de Ciências da Saúde (ESCS) ter sido ideológica e estruturalmente desenhada nas bases do próprio sistema de saúde público no que diz respeito à sua existência enquanto uma instituição de ensino integrada à uma Secretaria de Estado, no encontro, a instituição "ensino médico" e a instituição "serviço médico" criam convenções de interação que qualificam a relação entre essas instituições e entre as pessoas que delas fazem parte. Mas antes de explorar essa questão, os outros eixos temáticos que integram o currículo do curso de medicina na ESCS precisam ser apresentados.

\title{
OUTROS EIXOS
}

Outro eixo temático é o dos Módulos Temáticos. A descrição trazida pelo projeto pedagógico do curso de medicina da ESCS diz o seguinte:

\begin{abstract}
Os módulos temáticos apresentam abordagem interdisciplinar cujo conteúdo é organizado em problemas que constituem o elemento motivador para o estudo e momento de interação das disciplinas. [...] Esta metodologia por módulos traz implícita a prática da interdisciplinaridade. Ou seja, em cada módulo são embutidas as disciplinas que complementam todo o conteúdo de seus enunciados. [...] Desse modo elas estão livres de todo o peso acadêmico-administrativo que possuem na forma tradicional. Cada módulo se desenvolve em 2 a 8 semanas [...]. Dele, elaborase a árvore temática que dará origem aos problemas relacionados com o processo saúde-doença. (ESCS, 2001, 83)
\end{abstract}

O trecho mostra como a questão da interdisciplinaridade é enfatizada nas providências do projeto pedagógico. Os módulos temáticos acontecem como se cada um abrangesse várias disciplinas vinculadas à um único tema geral. Em cada módulo temático estão embutidos vários conteúdos de acordo com o enunciado de cada "problema" que é dado aos estudantes durante as aulas. Os módulos podem, em certa medida, ser considerados como a mistura de várias disciplinas que tem em comum temas semelhantes que, num curso tradicional de medicina, seriam tratados de forma separada, tal como disse um professor:

São nos módulos temáticos que a metodologia da Aprendizagem Baseada em Problemas é colocada em ação. Os módulos consistem de atividades em sala de aula aonde os professores sugerem a cada sessão uma situação-problema. São casos fictícios e, às vezes não - às vezes a gente monta situações de atendimento e situações terapêuticas que a gente vivencia na prática do dia a dia - e esses problemas tem de ser solucionados pelos estudantes de acordo com as capacidade e conhecimentos que eles já tem. A nossa escola visa um ensino da medicina mais próximo da realidade 
como ela se mostra. A gente critica muito a prática do 'conhecimento bancário', aonde o professor abre a cabeça do estudante, vomita conhecimento lá dentro e pronto. A ESCS busca não apenas o conhecimento teórico, mas também o desenvolvimento dos estudantes no que diz respeito a realidade da saúde brasileira. [...] Por exemplo: uma mãe que levou o filho no posto de saúde porque ele estava com tosse e dor de garganta há três dias. Não dá apenas para saber qual medicamento, tratamento ou exame aquela criança precisa fazer, porque o estudante é treinado a abranger a situação de saúde que é dada como um 'todo bio-psico-social'. Aquela criança não tem apenas tosse e dor de garganta. Ela mora numa casa aonde o pai violenta a mãe numa região da cidade na qual não ha saneamento necessário, a mãe está desempregada e não tem dinheiro para comprar a medicação que o medico receitou. Como solucionar o problema? Os estudantes tem que quebrar a cabeça para dar conta de resolver o problema. [...] As atividades nesse eixo temática são sempre baseadas nesses problemas dados aos estudantes em sala de aula como pequenos textos descritivos de situações que podem ocorrer na realidade [...] (Professor de medicina da ESCS. Fala registrada em diário de campo, 13/08/2013)

A ideia de integração dos conteúdos parece se evidenciar na abordagem dos problemas dados aos estudantes em sala de aula principalmente pelo fato de que a aproximação ao problema abrange questões fisiológicas e morfológicas do corpo humano; questões socioeconômicas e culturais, assim como questões do campo psicológico e emocional desses pacientes fictícios, personagens de problemas descritos durante as atividades, desta forma, a interdisciplinaridade é construída. A prática interdisciplinar se mostra no modo de se abordar, discutir e resolver os problemas e a integração do eixo dos Módulos Temáticos também acontece com outros eixos do curso tal como o de Habilidades e Atitudes (HA) e o de Interação Ensino-Serviço-Comunidade (IESC). A resolução dos problemas, segundo o relato de um estudante, acontece da seguinte dinâmica:

A turma recebe um problema, um caso clínico qualquer que é discutido em sala de aula e o professor dá indicações gerais do que estudar sobre o problema. Daí, depois de discutir superficialmente o problema, cada um leva o problema para casa e estuda o máximo que puder sobre os assuntos relacionados àquele caso. Na sessão seguinte todos discutem o problema juntos de novo e compartilham o que estudaram sozinhos a partir daquele problema. [...] Como as turmas são pequenas, dá pra todo mundo falar. [...] Para cada problema a gente estuda várias coisas relacionadas ao assunto sem depender muito dos professores porque isso diversifica as fontes de estudo. [...] A gente é mais autônomo porque somos nós que vamos atrás do conteúdo. Não é um professor só falando e falando [...] (Estudante de medicina da ESCS. Fala registrada no diário de campo, 17/10/2013)

O fio dorsal do eixo dos Módulos Temáticos são as atividades que acontecem nos chamados "grupos tutoriais", os quais são compostos de oito a doze alunos acompanhados de um docente que atua na função de tutor. Nos grupos tutoriais são desenvolvidas atividades de estudo com base em problemas segundo a "dinâmica dos sete passos", que pode ser destilada da seguinte forma e que se reflete em falas como a do estudante: a cada sessão tutorial, que tem duração média de duas horas por encontro, um problema é dado aos alunos na forma de um 
texto escrito que fora elaborado pelos docentes num momento anterior. No primeiro passo os estudantes leem o problema e destacam aqueles termos que desconhecem para que estes sejam esclarecidos antes que a discussão se inicie de fato. Em seguida os estudantes identificam o problema emitido pelo enunciado da questão. O terceiro passo se compõe de possíveis explicações que os estudantes devem oferecer à questão com base no conhecimento que já tem com o objetivo de formular hipóteses para o problema em questão e à sua solução. O quarto passo se trata da condensação dessas hipóteses em resumos explicativos feitos tanto de forma oral quanto de forma escrita. No quinto passo, o mais desafiador na visão de uma das professoras, são estabelecidos os objetivos de aprendizado que impliquem ao estudante confirmar, descartar, aprofundar ou complementar as explicações e hipóteses que levantaram no terceiro passo da atividade. Em seguida, os estudantes devem estudar de maneira individual as possíveis soluções para o problema, para que na sessão seguinte o problema seja rediscutido dentro do grupo novamente, agora com os novos conhecimentos estudados pelos membros do grupo tutorial. Estes passos estão dispostos no projeto pedagógico da escola, em alguns artigos publicados nas bases de dados sobre o tema e nos discursos que pude registrar por parte dos professores e estudantes com os quais tive a oportunidade de conversar sobre a metodologia e no modo como ela se desenrola nas atividades cotidianas dos processos de aprendizagem.

Outro eixo é o de Habilidades e Atitudes, destinado ao desenvolvimento de "habilidades clínicas e atitudes necessárias para o bom desempenho profissional" (ESCS, 2001, 85). As práticas pedagógicas deste eixo temático acontecem nos cenários das unidades da rede pública de atendimento e assistência de saúde e nos laboratórios da escola. Segundo o projeto pedagógico “as habilidades desenvolvidas são do tipo educacionais, de semiologia, comunicação social, procedimentos médicos e exames complementares" (Ibid., 86). A diversidade dessas atividades do eixo de Habilidade e Atitudes, ou "HA", como era chamada pelo pessoal da escola, é caracterizada da seguinte maneira no projeto pedagógico: No quesito das habilidades educacionais "o acesso à informação médica é a primeira atividade desenvolvida" (Ibid.) No quesito de semiologia acontecem demonstrações por um "instrutor, treinamento interpares, com manequins e simuladores ou com pacientes simulados e/ou verdadeiros." (Ibid.) No que diz respeito á comunicação social, acontecem “demonstrações em vídeo, observação de atendimentos, gravação em vídeo de entrevistas individuais para posterior análise e discussão nas reuniões devolutivas com os instrutores e demais membros" (Ibid.) No quesito dos procedimentos médicos também há “demonstração por instrutor e/ou por vídeo, 
treinamento individual e interpares, treinamento com a utilização de manequins e simuladores, treinamento em animais de experimentação e com pacientes verdadeiros.” (Ibid.) Finalmente, na parte de exames complementares há o aprendizado de "diagnósticos por imagem com demonstração por instrutor, treinamento individual com a utilização de arquivos didáticos e treinamento em pequenos grupos" (Ibid.), assim como aprendizado sobre questões voltadas à práticas em laboratórios clínicos com "práticas individuais sob supervisão de exames de baixa complexidade de realização." (Ibid.). Acompanhar etnograficamente o desenrolar das atividades nos eixos dos Módulos Temáticos e de Habilidades e Atitudes teria sido muito interessante e contribuiria muito para as reflexões neste capítulo, entretanto, as reflexões etnográficas se voltaram à antropologia institucional do que à antropologia dos processos pedagógicos a partir do momento que tomei conhecimento do Projeto UNISUS. ${ }^{5}$

Os Internatos Médicos, que consistem no "treinamento intensivo, contínuo[...] feito de forma rotativa e integrada" (ESCS, 2001, 87), como conta no projeto pedagógico. Os internatos acontecem nos dois últimos anos do curso e é o momento em que os estudantes de medicina adentram efetivamente no sistema público de saúde de maneira cotidiana. Os internatos são como estágios nos quais a experiência pedagógica acontece “'à beira do leito’ como no atendimento prestado aos pacientes nos consultórios de ambulatórios e postos de saúde" (Ibid.). No caso de outras faculdades, como a faculdade de medicina da UNB, os estudantes realizam seus estágios em um Hospital Universitário, ao passo que os estudantes da ESCS realizam o internato nas várias unidades da rede pública, desde as de menor complexidade, como postos de saúde e unidades de pronto atendimento, aos de maior, como clínicas médicas e centros cirúrgicos. $^{6}$

\footnotetext{
${ }^{5}$ Acompanhar as atividades dos grupos tutoriais em sala de aula era difícil por serem espaços e momentos um tanto quanto protegidos pelos sujeitos envolvidos por conta da natureza delicada desses momentos do processo de aprendizagem, que não se limita ao tempo de uma sessão. Um mesmo problema poderia ser discutido durante semanas pelo mesmo grupo, este sempre trazendo novos conhecimentos ou aprimoramentos que davam novas aberturas a outras discussões relacionadas ao problema. Eram nessas aberturas de discussão e diálogos dentro e fora da sala de aula que o processo de aprendizagem no eixo dos módulos temáticos aconteciam, por isso julguei que acompanhar tal processo de maneira intercalada e, inevitavelmente, cometendo faltas etnográficas, prejudicaria uma compreensão mais precisa do sentido que tal prática pedagógica tinha para meus próprios interlocutores e minha presença poderia atrapalhar o próprio processo pedagógico cotidiano.

${ }^{6}$ Não alongo reflexões sobre os Internatos Médicos, ficando marcada aqui, apenas à título informativo, a existência dessa atividade no currículo de medicina da ESCS porque ela não foi acessada etnograficamente devido ao tempo reduzido para a realização do trabalho de campo e às dificuldades burocráticas que seriam impostas à pesquisa
} 
O currículo também é composto por atividades de diferentes naturezas e se dividem entre atividades em grupos tutoriais, como foi descrito, Palestras e Conferências, Módulos Eletivos, Consultorias e outras Atividades Complementares. Os Módulos Eletivos são módulos obrigatórios, porém os estudantes tem a possibilidade de escolher dentro de uma lista de oferta que possibilitam a personificação do currículo. Segundo o documento que regulamenta esses módulos, a atividade se trata da "imersão do estudante em um serviço" (ESCS, 2013, 1). Funcionam como se fosse um módulo temático comum, com a diferença de que os estudantes tem a liberdade de escolher os módulos eletivos que desejam cursar de acordo com suas "vocações pessoais", na voz de uma professora.

\section{PROBLEMAS DA PEDAGOGIA}

A qualidade da transformação na formação médico-profissional através da integração entre ensino e serviço é suscetível ao modo com que se dão as relações e encontros entre o universo da pedagogia e o mundo do trabalho. Para as estruturas institucionais atuais é novidade ter estudantes acompanhando e realizando as atividades junto de profissionais que atuam nos serviços de saúde e as próprias relações entre as coletividades institucionais sofrem rupturas e desgastes na concretização de uma nova ordem no manejo das atividades cotidianas da instituição.

A noção de interdisciplinaridade fica clara ao lado da noção de "médico total", categoria usada pelos professores para falar do perfil profissional dos médicos e médicas que a Escola Superior de Ciências da Saúde (ESCS) busca formar. Segundo um dos professores um "médico total" é aquele que sabe ver o "todo bio-psico-social" dos pacientes, conforme ele relatou numa das diversas conversas que tive com ele e outros professores e professoras da ESCS. Segundo o projeto pedagógico da ESCS, as competências que se buscam alcançar no processo de formação são a "atenção à saúde"; "tomada de decisões"; "profíssionalismo" e "administração e gerenciamento" (ESCS, 2002, 54). O profissionalismo é descrito como "um conjunto de elementos que expressam o compromisso ético, moral e humanístico que os

etnográfica por razões de exigências acadêmicas de validação e avaliação ética requerida para entrada e permanência do antropólogo em ambientes hospitalares. 
médicos devem manter com o objeto de seu trabalho" e "são elementos fundamentais desta competência: comunicação e relacionamento interpessoal, ética, altruísmo, responsabilidade, humanismo e aprendizado permanente" (Ibid.). A ideia da formação de um profissional "médico total" traz uma certa visão de pessoa e profissional que a Escola busca construir na medida em que, através de estratégias de ensino e aprendizagem interdisciplinares e integradoras dos conteúdos e abordagens, eles possam adquirir competências tanto acerca da teoria clínica trazida pelos conteúdos quanto à parte prática da construção de um determinado tipo de "profissionalismo". Compreender o sentido da imbricação entre a formação médica através de uma prática pedagógica que acontece na interface da Escola com os serviços de saúde do Estado de modo precoce é compreender como a ideia de "médico total" é uma categoria importante para qualificar a noção da interdisciplinaridade e dos significados desse perfil de médico que a Escola visa construir.

Segundo Souza (2001), a formação profissional em medicina forma a identidade profissional dos estudantes principalmente no âmbito das atividades práticas.

\begin{abstract}
A formação médica, lugar de transmissão do saber e lugar privilegiado de reprodução da pratica médica, passa, além da aquisição de conteúdos e habilidades técnicas, pela apreensão do cenário social onde se desenrola a pratica assistencial institucionalizada e pela busca de uma identificação do aluno com seu professor. É sobretudo nas atividades práticas que o aluno vai construindo sua identidade profissional no que concerne aos valores sociais de uma prática com suas implicações no modo de vivenciar e realizar esta prática. (Souza, 2001, 89)
\end{abstract}

Os valores sociais que são reproduzidos na prática pedagógica proposta por instituições de ensino como a Escola Superior de Ciências da Saúde (ESCS) visam a formação do "médico total", isto é, do profissional que é competente na abordagem das esferas técnicas, sociais, éticas e administrativas de seu trabalho e que também saiba olhar e agir na prática profissional cotidiana levando em consideração os múltiplos aspectos da vida dos pacientes e do seu ofício, não olhando apenas para os aspectos biológicos, mas vendo através da ótica interdisciplinar socialmente orientada de sua ação e formação profissional.

Ainda no tocante ao tema da interdisciplinaridade na formação médica, Vilela e Mendes (2003) conduzem à uma descrição crítica dos processos de aprendizagem reproduzidos e praticados na Escola Superior de Ciências da Saúde (ESCS).

Para a superação desse modelo [biomédico] que está na raiz da crise na saúde, propõese a transição para um paradigma da produção social da saúde, o qual tem seus 
fundamentos calcados na teoria da produção social. Tal teoria permite romper com a setorialização da realidade e, dessa forma, a produção social da saúde, além de responder por um estado de saúde em permanente transformação [...]. Trata-se de nova forma de resposta social organizada aos problemas de saúde, orientada pelo conceito positivo de saúde e pelo paradigma da produção social da saúde e que deve atuar sobre os nós dos problemas críticos, baseado em um saber interdisciplinar e um fazer inter setorial. [...] Essa mudança no campo da saúde deve trazer transformações na área da educação, cujas transformações em curso mostram a transição da concepção tradicional para a concepção crítico-reflexiva da educação. No primeiro caso temos uma prática educativa calcada na pedagogia da transmissão, centrada no professor e desvinculada da realidade. A concepção crítico-reflexiva busca a articulação entre teoria e prática, a participação ativa do estudante e a problematização da realidade. (Vilela e Mendes, 2003, 529-30. Grifo meu.)

Procurando uma resposta aos problemas de saúde com base em saberes interdisciplinares com cunho crítico e reflexivo, a inserção dessas concepções integradoras e interdisciplinares no campo no ensino em medicina inserem o projeto da Escola Superior de Ciências da Saúde (ESCS) em um campo ideológico complexo. A metodologia pedagógica da ESCS vem como resposta aos modelos tradicionais de ensino em medicina e à uma necessidade interna do próprio sistema de saúde público brasileiro em formar mais médicos a partir de outra estratégia formativa voltada à atenção básica.

O eixo Interação Ensino-Serviço-Comunidade (IESC) era uma das partes do currículo mais criticadas pelos estudantes da Escola. Uma expressão deste descontentamento veio de interações informais, como por exemplo uma suposta festa organizada por estudantes que haviam recentemente concluído todas as quatro partes do "IESC", festa que aconteceu no final de 2011 e se chamou "Morte ao IESC" na qual teve uma "fogueira para quem quisesse queimar seus portfólios”. Uma outra crítica dos estudantes em relação à esta parte do currículo veio através de uma paródia musical feita por alguns dos estudantes. A letra da música dizia o seguinte:

IESC, duzentas semanas de terror com você/ No Recanto, no Riacho, em Taguá, no Sobrado/ Num cenário abandonado, preceptor vagal/ Pro centro de saúde carona vai rolar/ Cem km por semana assim vai me quebrar/ Tudo começou três anos atrás no Plano Piloto [...] (Letra de paródia musical feita pelos estudantes registrada em diário de campo, 23/10/2013)

Por mais insólitos que alguns desses dados possam parecer, na realização da festa e nessa paródia musical feita pelos estudantes, é possível ver uma expressão sincera e descontraída da forma com que os estudantes encaram este eixo temático do currículo e de que forma pensam sobre esta parte do currículo quanto sua realização na prática cotidiana. 
Um outro estudante ainda se referiu ao eixo de Interação Ensino-Serviço-Comunidade (IESC) como um "safári pelo serviço de saúde que não cumpre o papel social que se propõe". Para desdobrar o sentido dessa crítica, pensar sobre a noção de "safári" é interessante para apreendermos como que os estudantes encaram o eixo temático de Interação Ensino-ServiçoComunidade (IESC) segundo essa metáfora. Primeiro, a ideia de "safári" evoca a noção de deslocamento, e segundo, evoca uma certa noção de exotismo. Um outro estudante disse que havia "aluno que mora em Sobradinho e tem que se deslocar pra Samambaia [cidades distantes $45 \mathrm{~km}$ entre si] para fazer o IESC" e que isso desgastava os estudantes e os desmotivavam. O deslocamento de suas áreas de moradia para além da Escola e à lugares distantes, por um lado, gera desmotivação, mas, por outro, gera um certo grau de interação entre os estudantes pois eles esquematizam caronas entre aqueles que moram perto uns dos outros. Mas para além do deslocamento físico necessário, imputar ao eixo pedagógico a noção de "safari" é evidenciar o vínculo superficial e o caráter en passant das atividades e, em certo sentido, a impermanência nos cenários da prática. A impressão é que ao longo do curso os estudantes e professores "vão passando" de unidade à unidade de serviço em nome da interação implicada pelo projeto pedagógico em seu ideal de formar profissionais conhecedores de uma "realidade" naturalizada com os serviços básicos de saúde, com mínima permanência e vínculo integrador.

A ideia integradora e comprometida com a "realidade total" dos pacientes, que está relacionada com a ideia do perfil de um "médico total", discutida anteriormente, revela seus limites quando se enxerga a proposta pedagógica como um todo a partir de uma análise mais distanciada, bem como é possível perceber na fala desse estudante:

\footnotetext{
Deve haver profissionalismo médico para pensar a relação medico-paciente de forma mais contundente, mais comprometida. A "psico-coisa" ainda não foi incorporada direito e ela é crucial para os processos de cura e não podemos pensar que o internato é heroico, porque ele é, na verdade, clínico. E é difícil manter essa "psico-coisa" em atuação porque não é possível haver continuidade ou manutenção no que um estudante faz nos internatos, porque quando a gente segue no curso, as coisas voltam a ser como eram antes para os pacientes. (Estudante de medicina. Fala registrada em diário de campo, 13/11/2013. Grifo meu.)
}

Segundo esse estudante, os internatos, parte curricular essencialmente prática dos dois anos finais do curso, não são "heroicas", mas "clínicas", isto é, essencialmente voltadas para um processo de aprendizagem em que os pacientes continuam, de qualquer maneira, à mercê do modo de operacionalização do sistema público de assistência, com seu modo cotidiano padrão de trabalho, não havendo, em tese, espaço para que o estudante transforme a realidade. 
Apesar de a ESCS adentrar o SUS mais do que o SUS adentra a ESCS no que diz respeito ao mundo da prática, parece não haver espaço ou tempo para que o estudante contribua para a transformação da realidade.

Pensando pela ótica do distanciamento, a ideia de totalidade é comprometida pelo caráter meio superficial da relação que os estudantes acabam criando com os pacientes que passam por seus processos formativos. No discurso dos estudantes, a ideia de um "médico total" implica numa certa responsabilidade heroica colocada sobre eles pela conjugação das várias facetas do cuidado de um paciente, mas tal bravura é imperfeita porque a formação médica na ESCS continua sendo clínica em sua visão. Por mais que a presença dos estudantes na rede pública possa parecer positiva pelo lado da ideia da integração e visão total que implica, o balanço final, ao menos enquanto os estudantes estão em processo de formação, continua o mesmo, porque, mais cedo ou mais tarde, eles irão seguir o curso, ir para outra unidade, depois outra, e assim por diante.

Mesmo havendo uma proposta ideológica integradora que se efetiva na prática pedagógica dos estudantes durante as atividades no curso, existem entraves à integração e holismo, que se devem a dificuldades inerentes ao próprio processo de ensino enquanto este se vincula à "realidade" do Sistema Único de Saúde (SUS). Concluindo, é ambígua e problemática a posição dos estudantes nos cenários de prática pedagógica no sistema público de assistência que coloca um dilema inerente ao projeto pedagógico que parece cria um círculo vicioso dentro dos processos de formação que faz a interação entre ensino e serviço paradoxal em sua própria base.

Tive acesso a um relato de experiência feito por uma estudante da ESCS numa rede social na internet em que ela faz um desabafo e uma crítica em nome de seu grupo quanto ao fato de que possivelmente teriam seu trabalho de Interação Ensino-Serviço-Comunidade impedido pela escola de ser apresentado no $3^{\circ}$ Congresso de Medicina e Enfermagem da Escola Superior de Ciência da Saúde, o CONGRESCS, que aconteceu nas dependências da escola nos dias 16 e 17 de outubro de 2013. Trago um trecho do relato, que embora seja longo, julgo bastante relevante:

Gostaria de pedir a paciência de todos os estudantes para ler esse depoimento que interessa a todos que tem ou já tiveram alguma crítica ou problema com o eixo IESC. Venho em nome do meu grupo expressar nossa indignação perante o que aconteceu 
hoje. Faltando apenas 2 dias para o CONGRESCS, recebemos a notícia de que nosso relato de experiência foi censurado pela escola por ser considerado "forte" e "agressivo, e que temos 2 dias para fazer um trabalho novo para apresentar. Poucas pessoas sabem, mas meu grupo de IESC presenciou um terrível acontecimento durante a formulação de nosso trabalho: a morte da paciente sobre a qual nosso trabalho estava centrado. Isso sem dúvidas causou um forte impacto no grupo e decidimos deixar o [trabalho previamente planejado] (pois não havia mais sentido fazer com o falecimento da paciente, óbvio) e fazermos com este caso nosso relato de experiência para apresentarmos no congresso. Nosso trabalho teve o objetivo de contar a experiência que tivemos em nos deparar com as enormes falhas do sistema de saúde logo no $1^{\circ}$ ano. Que nosso sistema de saúde apresenta inúmeras falhas não é novidade para ninguém, porem tivemos a "oportunidade" de dar de cara com essas falhas no nosso primeiro trabalho da escola.

Em resumo aconteceu o seguinte: Estávamos realizando um trabalho com uma paciente de 82 anos com pé diabético que infelizmente veio a falecer. Criticamos, no nosso trabalho, a incapacidade da atenção básica em reconhecer a vulnerabilidade daquela família, visto que a clínica de nosso cenário (responsável pela paciente) só veio a tomar providências em relação à paciente tarde demais. Desde a primeira visita domiciliar à paciente alertamos a clínica que a paciente precisava urgentemente de algum acompanhamento (visto que a paciente se locomovia de cadeira de rodas e não tinha condições de ir até a clínica). Neste primeiro momento não nos foi dado ouvidos, talvez por fazer pouco caso da hipótese de alunos do primeiro ano, não sei. Enfim, o quadro da paciente se agravou e a cirurgia [...] teria sido marcada para uma semana depois pois não havia vaga. Aí está nossa segunda crítica: a paciente teve que esperar uma semana para realizar a cirurgia [...] por falha do sistema de saúde. [...] A paciente desenvolveu insuficiência renal e foi encaminhada para hemodiálise, mas não pôde realizá-la pois não havia vagas. Conclusão: Após muitas semanas no hospital, [...] a paciente veio a falecer.

Com nosso trabalho queríamos apontar as falhas do sistema de saúde que levaram à morte da paciente e relatar nossa experiência frente à isso. Infelizmente fomos censurados desde o início da criação de nosso relato. [...] Não queremos de jeito nenhum fazer denúncias nem prejudicar nossa faculdade, só queremos expressar nossa indignação perante toda essa experiência. [...] Hoje recebemos a notícia que nosso trabalho não poderia ser apresentado pois traria repercussões negativas para o eixo IESC. [...] Decidimos não fazer outro trabalho. Ou apresentamos o que está pronto ou não apresentamos. (Publicação feita por uma estudante do curso de medicina no grupo dos estudantes da ESCS na internet registrada em diário de campo em 14/10/2013)

Quando a notícia de que o trabalho não seria apresentado saiu, os estudantes que estavam na escola neste dia disseram que “o IESC desenvolveu o propósito de aproximá-los da comunidade e ajudar a desenvolver senso crítico em relação ao sistema de saúde" ou afirmando que "a faculdade está sendo incoerente". Outra estudante considerou o trabalho como um esforço "que quer relatar para o futuro da medicina a realidade e inclusive propor soluções" e parecia ser unânime entre os estudantes a opinião de que o trabalho deveria ser apresentado em qualquer circunstância. Enfim, até o dia do congresso a escola decidiu permitir os estudantes apresentarem o trabalho como havia sido feito. 
Mesmo assim, o fato de o trabalho ter sido censurado pela escola por este ser considerado "forte demais" revela a relação de poder que existe entre a Escola, os estudantes, os professores e o serviço de saúde, mais uma vez. Parece haver uma relação triangular de poder entre os estudantes e os professores no que sua concepção implica na elaboração de um grupo, isto é, de uma classe que ocupa uma determinada posição dentro das estruturas internas da escola. Este grupo entra em esquema de interface com os serviços de saúde, concebidos por outros grupos, no caso observado, os Agentes Comunitários de Saúde. Em outro ponto está a Escola, com as posições dirigentes ocupadas pela diretoria e coordenações dos cursos atados em relações políticos com instituições do serviço de saúde, ou seja, o Sistema Único de Saúde (SUS), fazendo o papel do "serviço" dentro da estratégia pedagógica que visa a integração entre os níveis da aprendizagem aos níveis dos mundo do trabalho em saúde. Dessa forma, na imbricação destes três atores, isto é, entre os estudantes, as equipes do sistema de saúde e os professores, em mais um ponto da estrutura pedagógica existe reprodução de relações de poder que se expressam em acontecimentos como este em que a escola se manifestou censurando o trabalho dos estudantes por temer sujar a reputação do módulo temático de Interação EnsinoServiço-Comunidade. Talvez seja pelo não reconhecimento da qualidade da relação entre as instâncias do serviço de saúde e a Escola como meio pedagógico; talvez seja pelo fato de a Escola não poder fazer nada quanto à situação da paciente por mais que o processo de aprendizagem dos estudantes estivesse acontecendo com base na paciente; ou talvez pelo fato de que a Escola, por fazer parte do SUS, não querer comprometer a imagem do próprio SUS pelas suas faltas e, por consequência, sujar a imagem da Escola. As hipóteses para a tentativa de impedimento da apresentação podem ser bastante variáveis, mas não importa qual seja "verdadeira", a relação da Escola com o SUS no eixo de interação entre ensino e serviço é problemática e, como mediadora dessas instâncias, a ESCS não encontrou ainda uma forma de redimensionamento capaz de alavancar interação harmoniosa entre a gestão do ensino e os serviços de saúde.

Uma estudante disse, na opinião dela, que a Escola tem a forma ideal de formar os estudantes, mas ao mesmo tempo lamentava que a realidade do sistema público de saúde não esteja preparada plenamente para um projeto pedagógico deste porte, isto é, com uma proposta que integra, no próprio processo de aprendizagem do exercício médico, o ensino em saúde e o serviço em saúde. Com suas palavras, a estudante disse o seguinte: 
O SUS não é ideal e os profissionais do próprio SUS não entendem a ESCS. Deve haver uma reflexão constante por parte dos profissionais da ESCS sobre como a secretaria de saúde e o SUS são organizados. [...] Lamento o fato de que a secretaria não dá apoio á nossa metodologia. A própria secretaria de saúde não nos entende bem. Se o SUS não é ideal, a ESCS também não é ideal por serem frutos da mesma jurisdição; e pelo fato de que a metodologia, por falta de apoio necessário, não se torna realidade praticável. A metodologia da ESCS é ideal, o SUS é real. (Estudante de medicina. Fala registrada em diário de campo, 13/11/2013)

Chama atenção a distinção que a estudante faz entre real e ideal no que diz respeito ao projeto pedagógico da escola frente ao serviço público de saúde. Fazendo uma crítica ao modo de operacionalização da metodologia adotada pela escola, a divisão entre ideal e real feita pela estudante evidencia a existência de uma descontinuidade entre o que a escola pretende como um projeto de educação em saúde e aquilo que é possível de se fazer na realidade do próprio sistema de saúde, de modo com que por mais "inovador" e "paradigmático" que o projeto seja, sua realização depende de fatores externos ao projeto pedagógico em si. A formação ideal pode ser considerada como essa que busca a formação do perfil de um "médico total" que teve seu processo formativo implicado no vínculo da Escola com os serviços de saúde pública e com atividades pedagógicas nas quais é o estudante o ser autônomo quanto à construção do conhecimento. Isso se expressa na fala de um estudante que criticou as estruturas da própria escola no que diz respeito à infraestrutura e gestão da vida estudantil:

\begin{abstract}
Muitas vezes a gente chega aos hospitais para fazer internato e não conseguimos fazer porque naquela área do hospital já existem preceptores ${ }^{7}$ de outras faculdades. [...] A pesquisa na ESCS é muito incipiente. Não existem bolsas e os laboratórios são inadequados para um curso de medicina. Não existe a possibilidade de fazermos pesquisas de ponta como outras faculdades da cidade [...]. Sentimos vergonha de irmos a congressos de iniciação científica em outras faculdades, universidades, aonde expõem-se trabalhos que falam da 'síntese da proteína catabólica $\mathrm{x}, \mathrm{y}, \mathrm{z}$ ' quando nossos trabalhos falam sobre 'a qualidade de vida dos assistentes comunitários de saúde'. [...] Falta muita estrutura nos laboratórios de anatomia, histologia e isso gera um desestímulo que não deve ser ignorado. Por causa disso chegamos ao internato inseguros do que realmente sabemos por causa da falta de treinamento que temos na escola. (Estudante de medicina. Fala registrada em diário de campo, 01/10/2013)
\end{abstract}

Há um paradoxo esboçado. O método pedagógico diferenciado é motivo de orgulho para a os estudantes se o pensarmos em contraste com os modelos tradicionais de ensino, mas a evocação do sentimento de "vergonha" é significativo para pensarmos como que é complexa a imbricação entre teoria e prática dentro de um sistema institucional que não está preparado

\footnotetext{
${ }^{7}$ Pessoas da área médica responsáveis por conduzir e supervisionar, através de orientação e acompanhamento, o desenvolvimento de médicos residentes e estudantes em fase de formação nas especialidades de um hospital.
} 
para alavancar um processo de aprendizagem harmonioso segundo os preceitos que imprimem um projeto pedagógico inovador pela mediação que busca entre a gestão do ensino e do serviço em saúde. Existe assim uma determinada incompatibilidade de perfis que a Escola e os estudantes almejam construir ao longo dos processos pedagógicos. Ou seja, entre o perfil do "médico total", formado segundo uma abordagem "bio-psico-social" voltada à "atenção básica" e o perfil do médico "pesquisador", que faz pesquisas de ponta, parece haver uma forma de alteridade entre os valores que cada perfil evoca. Um conflito de princípios aparece. Dentro do contexto maior de formação voltada à "atenção básica" que a Escola Superior de Ciências da Saúde (ESCS) implementa enquanto proposta política e pedagógica, a suplementação de pesquisas de ponta parece se situar fora do horizonte de valores que a ESCS busca implementar.

Talvez a crítica direcionada à falta de incentivo à pesquisas de ponta sejam devido à própria natureza ideológica e política da Escola, que é formar profissionais médicos para atuarem na atenção básica, então nada mais natural os estudantes produzirem trabalhos acadêmicos voltados aos âmbitos da atenção básica; talvez nem os estudantes tenham compreendido plenamente a proposta ideológica e política da Escola por criticarem a qualidade dos trabalhos produzidos; ou talvez a sobreposição dos sentimentos de "orgulho" e de "vergonha" sejam um sinal de um processo em movimento de adaptação e de transformação das lógicas de ensino e gestão que ainda estão em reestruturação conceitual e prática, o que naturalmente gera conflitos e disputas em torno do projeto educacional e da gestão pública na interface entre educação e saúde.

Há um dilema que reside no fato de que a crítica direcionada à "realidade" do sistema de saúde é permeada por juízos quanto à precariedade do próprio sistema de saúde e, mais principalmente, à falta de entendimento relacional entre a Escola e o SUS. Em outras palavras, se a formação na ESCS é tida como ideal e que por princípio acontece com base na relação direta entre a Escola e o serviço público de saúde local - que não é uma relação clara na qual tenham sido bem estabelecidos os posicionamentos de cada instituição diante do projeto pedagógico -, que tipo de formação ideal é essa que acontece com base em uma realidade tão criticada pela gestão dos processos institucionais e políticos? O processo pedagógico acontece no "mundo real" do SUS e esse real é conhecido por ser cheio de problemas que vão desde os níveis infra estruturais aos níveis políticos e administrativos da gestão institucional, e até da gestão ideológica da vida pública. Isso torna o “ideal” em algo que em si é bastante dilemático 
internamente. Forma-se na "realidade" do SUS para a realidade do SUS. Duas realidades coexistem, uma é a realidade idealizada pelos preceitos pedagógicos da Escola, outra é a realidade do mundo do trabalho e do mundo das políticas institucionais. Se as relações políticas entre a Escola e a Secretaria de Saúde são problemáticas na alegação de um reconhecimento imperfeito entre as duas, esse ideal que se ancora numa realidade que por natureza é imperfeita, esse ideal também são seria, assim, imperfeito da mesma maneira?

A consolidação e execução de um projeto pedagógico como o da ESCS, levando em consideração o quadro geral que apresentei com dados e reflexões neste capítulo, se levarmos em consideração o processo de racionalização inerente a um programa de ensino, ele parece ainda não ter conseguido encontrar caminho bem consolidado que seja capaz de abarcar a alteridade gerada dentro desse campo de ensino médico, principalmente no tocante à gestão dos processos pedagógicos e políticos. A Escola Superior de Ciências da Saúde (ESCS) se situa, assim, na posição de mediadora entre uma proposta pedagógica diferenciada que busca estabilizar, ou melhor, harmonizar na interação entre ensino e serviço e o mundo da vida política e de gestão do Estado. Contudo, essa característica mediadora não foi plenamente realizada e a mediação em si ainda não foi concluída e está em processo.

Segundo Mary Douglas (1986), para que haja um mínimo de acordo tácito e implícito entre as instituições sociais no sentido amplo das conceptualizações culturais que estruturam ordenamentos sociais e sistemas simbólicos, é necessário alimentar um campo cognitivo que se estruture sobre o desafio de se adaptar e se adequar ao funcionamento do universo, isto é, à concepção de que é inescapável o fato de que mundo funciona do modo como funciona e que é por isso que se age desta ou daquela maneira. A autora coloca:

As condições para que surjam convenções estáveis são muito mais estritas do que
pode parecer. [...] Para que uma convenção passe a ser uma instituição social legítima
é necessário uma convenção cognitiva paralela que lhe dê apoio. [...] Aqui, presume-
se que a maior parte das instituições mais estabelecidas, quando desafiadas, sejam
capazes de concatenar suas reivindicações à legitimidade com sua adequação à
natureza do universo. Uma convenção é institucionalizada quando se indaga: Por que
você age assim? Embora a primeira resposta possa ser enquadrada em termos de uma
conveniência mutual em relação à um questionamento maior, a resposta final se refere
ao modo como os planetas sao fixados no céu ou como os planetas e os seres humanos
se comportam naturalmente. (Douglas, 1986, 58-9)

A ESCS adentra o sistema de saúde através de uma imbricação natural que o próprio projeto pedagógico cria entre os processos de ensino e os processos do serviço. Há uma 
reprodução de relações de poder entre a escola, representada pelos seus professores e estudantes, e as equipes de saúde em que cada relação é legitimada, no sentido do que a autora coloca, conforme os princípios que as regem, e assim, as ações que integram o ensino e o serviço são colocadas à prova no campo prático da própria ideia de integração que ainda não foi plenamente estabilizada. Os dois lados cedem e os dois lados demandam. Pode-se ver uma relação de reciprocidade institucional na base de todo o processo pedagógico. A natureza do universo é a combinação entre o ensino e o serviço e os atores que entram em contato entre si durante as atividades pedagógicas, isto é, estudantes e professorem com as equipes de saúde e todas as combinações possíveis. Os grupos criam um consenso mais ou menos implícito em que a natureza da relação que estabelecem acontece em prol do processo de formativos dos estudantes, mas essa relação ainda parece não ter sido compreendida no campo da gestão dos processos cotidianos.

De um lado, no projeto pedagógico os valores ligados à ideia de "integração", tal como a formação do perfil de "médicos totais" com concepções e visões do "todo bio-psico-social" e de gestão logística na vinculação entre a ESCS e o SUS, a organização das práticas é factível, mas se localiza em uma cadeia de relações repleta de disputas de força atreladas à gestão democrática da saúde e seu ensino. De outro lado, a prática, segundo o ponto de vista que estudantes e professores tem das atividades pedagógicas na ESCS, existem dificuldades inerentes à execução do Projeto que, pela natureza das estruturas estatais de controle e gestão da máquina pública, inserem a "inovação" do ensino em medicina em campos políticos que gestam e incentivam a criação de novas instituições que buscam formação médico-profissional diferenciada no contexto local, quiçá, nacional e até internacional.

Pensando localmente, as ambiguidades inerentes aos processos pedagógicos da ESCS tornam o processo cultural mais geral e ampliado de transformação do ensino médico disputado e repleto de reproduções de relações de poder, de interesses institucionais e de conflitos que se inserem em arenas públicas em que a transformação da instituição formação médica pode estar em jogo. O questionamento maior é que o Projeto da ESCS seja capaz de trazer transformações e mudanças no Sistema Único de Saúde (SUS) através da formação dos "médicos totais", entretanto, quando o processo chega nas arenas da política, a impressão que se tem é que o Projeto só ganha existência no mundo político, que apesar de parecer ser ideologicamente bem 
resolvido, no campo da prática é recheado de dilemas, conflitos e fronteiras institucionais, e é sobre isso que o próximo capítulo fala. 


\section{CAPÍTULO 3 \\ DO PROJETO À POLITICA DO PROCESSO}

Há um processo em transformação que se localiza tanto no universo das ideias quanto no universo das práticas no que diz respeito ao ensino da medicina na atualidade. Como apontei nos capítulos anteriores, a mudança de perspectivas políticas do Estado brasileiro voltadas para o ensino em saúde na atualidade se expressam através de debates e projetos políticos nos quais propostas de modelos pedagógicos de formação médica alternativos aos modelos tradicionais tem sido sugeridas nas arenas de discussão intelectual e política mais amplas. No contexto delimitado da saúde pública do Distrito Federal esteve em discussão o "Projeto UNISUS", o qual visava a criação de uma nova universidade pública de medicina no Distrito Federal, a futura Universidade de Ciências da Saúde do Distrito Federal, ou seja, a UNISUS. O processo de criação da UNISUS, que ainda estava em andamento quando realizei a pesquisa de campo, foi repleto de tensões e de alinhamentos entre os diversos atores institucionais envolvidos com o novo projeto.

É imprescindível que seja explicitada a rede institucional de atores que a pesquisa aborda. A Figura 3 traz um mapeamento básico que pode ser tratado como um sistema estruturado por hierarquias que compõem uma rede institucional na qual o Projeto UNISUS encontrou sua arena de discussão e onde sujeitos políticos e sociais, face-a-face uns aos outros, representando instituições, definiram o debate em torno do processo de transformação institucional.

O governo do Distrito Federal é vinculado ao governo federal, pela natureza federativa da organização do Estado brasileiro e pela sinergia das políticas públicas entre estes dois níveis do sistema de subordinações das estruturas políticas estatais. Nas instâncias legislativas locais do GDF está a Câmara Legislativa do Distrito Federal (CLDF), que sanciona leis públicas no DF e tem influência deliberativa sobre o projeto da nova universidade. Seguindo nesse sistema, está a Secretaria de Estado de Saúde do Distrito Federal (SES-DF) que, em uma sentença, detém e centraliza institucional, administrativa e burocraticamente todo sistema público de assistência de saúde do Distrito Federal. Como uma das instituições diretamente vinculadas à Secretaria de Estado de Saúde do Distrito Federal (SES-DF), a Fundação de Ensino e Pesquisa em 
Ciências da Saúde (FEPECS) mantem sob sua égide organizacional três escolas voltadas para cursos na área da saúde. São a Escola Superior de Ciências da Saúde (ESCS), a Escola Técnica de Saúde de Brasília (ETESB), e a Escola de Aperfeiçoamento do Sistema Único de Saúde (EAPSUS), como já expus anteriormente.

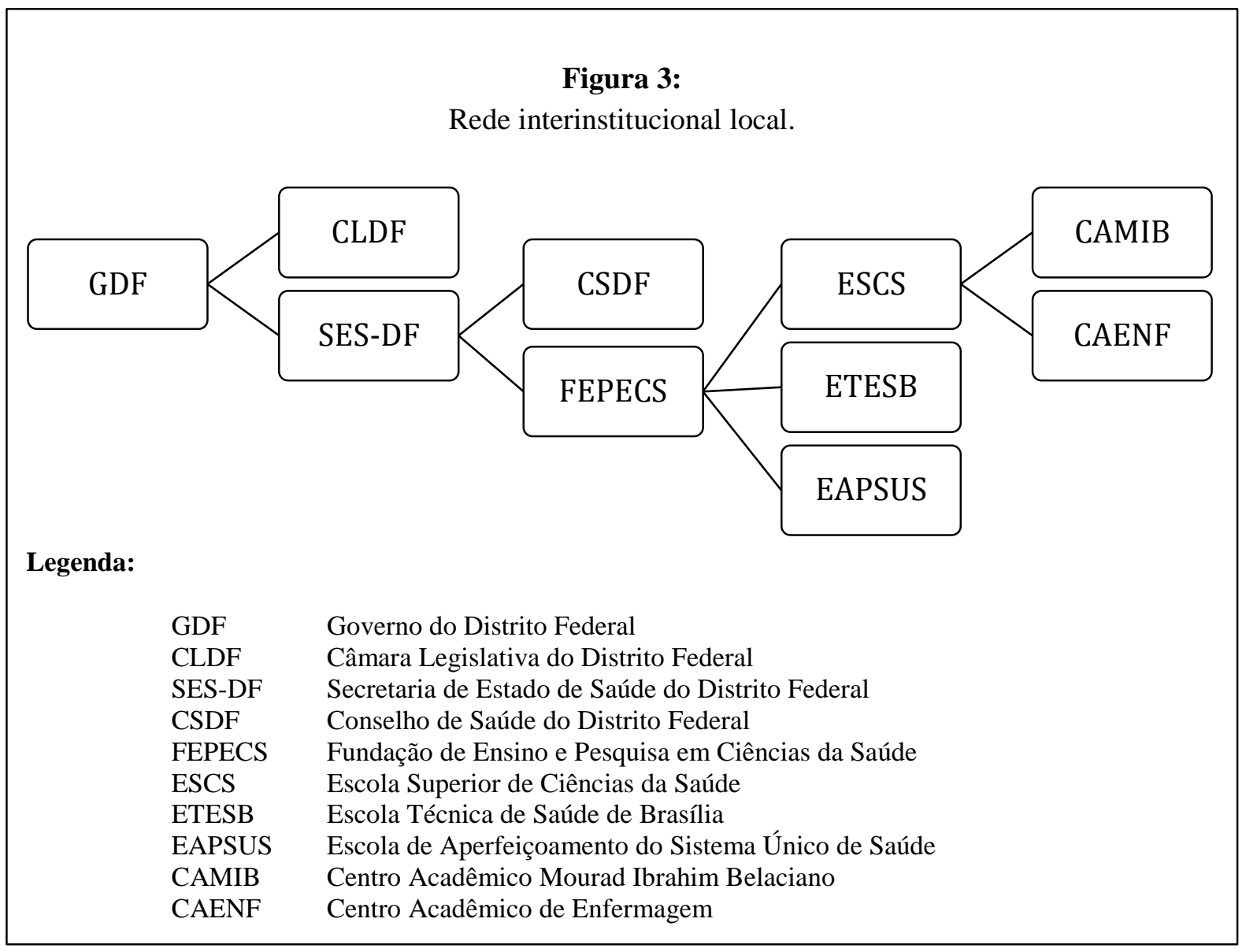

A Escola Superior de Ciências da Saúde (ESCS) foi o campo central da pesquisa e ocupou a posição de quarta melhor faculdade de medicina do país segundo o Exame Nacional de Desempenho de Estudantes (ENADE), fator de orgulho para os que dela fazem parte. Pelo peso maior dado ao ensino superior frente os níveis técnicos e de aperfeiçoamento, a ESCS ganhou mais força perante as outras escolas (ETESB e EAPSUS) mantidas pela Fundação de Ensino e Pesquisa em Ciências da Saúde (FEPECS) e, ao longo de seus 12 anos de funcionamento, adquiriu impulso político para configurar uma disputa de interesses com a própria instituição que a fundou, a FEPECS, ao protagonizar o processo de criação da nova universidade, o qual abordo com ênfase neste capítulo. 
Seguindo a descrição da rede hierárquica institucional, os polos institucionais oficiais da representação estudantil dos cursos de graduação em medicina e enfermagem dentro da ESCS existem através dos dois centros acadêmicos: Centro Acadêmico Mourad Ibrahim Belaciano (CAMIB), dos estudantes de medicina; e o Centro Acadêmico de Enfermagem (CAENF), dos estudantes de enfermagem. A ESCS possui dois campi, um no Plano Piloto, bairro da área central de Brasília, onde fica a sede do curso de medicina e outro campus em Samambaia, uma das cidades satélites localizadas a cerca de 25 quilômetros do centro de Brasília, onde se localiza a sede do curso de enfermagem. O curso de graduação em enfermagem foi criado no ano de 2008 e até o momento teve duas turmas formadas. Em prol do recorte da pesquisa, o foco da pesquisa foi sobre o curso de medicina de modo que, apesar de o curso de enfermagem fazer parte da ESCS, apenas ouvi relatos indiretos sobre as opiniões e acontecimentos pontuais que aconteciam no campus de Samambaia.

Na implementação da futura Universidade de Ciências da Saúde do Distrito Federal (UNISUS), o Conselho de Saúde do Distrito Federal (CSDF) foi um dos atores sociais principais que teve ampla influência no projeto da universidade projetada no que se refere ao “controle social” em saúde. Constituindo espaços de participação da sociedade civil através de membros representativos de instituições locais relacionadas ao campo da gestão da saúde, os Conselhos de Saúde são instituições que tem como finalidade atuar na formulação estratégica das políticas de saúde e no controle de sua execução, em tese, como um dos principais meios de interface entre a sociedade e o Estado e como mecanismo democrático participativo (Sposati e Lobo, 1992; Landerdhal et al., 2010; Shimizu et. al. 2013; Teixeira, Simas, Costa, 2013).

Para compreender como se dá a relação entre indivíduo e instituição, sigo a partir da perspectiva de Mary Douglas (1986), pois ela ajuda com ferramentas analíticas perspicazes para compreender o modo com o qual essa rede institucional e também como as pessoas que a compunha, agiam, se comportavam e se posicionavam no processo de transformação abordado. A autora coloca o seguinte:

Qualquer instituição que vai manter sua forma precisa adquirir legitimidade baseandose de maneira muito nítida na natureza e na razão. Então ela propiciará a seus membros um conjunto de analogias por meio das quais se poderá explorar o mundo e com as quais se justificará a naturalidade e a razoabilidade dos papéis instituídos, e ela poderá manter sua forma contínua, identificável. Assim, qualquer instituição começa a controlar a memória de seus membros; ela os leva a esquecer experiências incompatíveis com aquela imagem de correção que eles têm de si mesmos e traz para 
suas mentes acontecimentos que apóiam uma visão da natureza que lhe é complementar. (Douglas, 1986, 132)

A autora contribui para a compreensão da natureza das relações entre indivíduoinstituição num nível epistemológico que oferece perspectivas analíticas para apreender o sentido do posicionamento dos atores sociais dento da rede institucional para que seja possível destacar algumas analogias existentes em seus discursos. Segundo a perspectiva enunciada, a constituição das instituições sociais a partir de uma perspectiva histórica por analogia à natureza, a analogia natural da rede institucional pode ser considerada como sendo o próprio Sistema Único de Saúde (SUS). Enquanto projeto ideológico que evoca os princípios de igualdade, integralidade, universalidade, equidade e participação, esses valores se estendem amplamente desde um campo político que movimenta a questão da educação médica e exprimem, o Projeto UNISUS e a profundidade que esses valores atingem na nossa sociedade.

O Sistema Único de Saúde (SUS) é tido, nas entrelinhas do discurso dos sujeitos envolvidos, não apenas como uma estrutura administrativa assistencial de saúde, mas também como um vetor de valores ideológicos e políticos estruturantes. Enquanto projeto ideológico e propósito moral, o SUS é considerado, pelo ponto de vista dos sujeitos envolvidos, como algo que está no nível do inquestionável, isto é, como algo que é naturalizado. Situar o SUS num campo em que seus princípios morais são inquestionáveis, significa situá-lo no campo da sua irredutibilidade e, ao mesmo tempo, significa operá-lo discursivamente como se estivesse fora da intervenção humana cotidiana, colocando a legitimação de diversos procedimentos políticos das coisas como elas são, no caso, que constrói o projeto institucional nos moldes que ele existe. Para que sua convenção fosse institucionalizada e estabilizada, a justificativa maior que a instituição tem é baseada no SUS, sistema que foi naturalizado do ponto de vista dos sujeitos envolvidos e sobre o qual o Projeto UNISUS ganhou legitimidade para existir.

Um primeiro dilema aparece. Era comum escutar falas, até mesmo dos estudantes e professores da Escola Superior de Ciências da Saúde (ESCS), que evocavam a precariedade infra estrutural e de gestão política do Sistema Único de Saúde (SUS) enquanto se olhava para o lado prático dos serviços prestados por esse sistema assistencial. Contudo, falar mal do SUS enquanto projeto ideológico, isto é, enquanto uma proposta moral e política enquanto justificativa, era quase uma violação - ou até mesmo, profanação. Tomado como pressuposto ideológico e moral, o SUS era base referencial primordial sobre a qual o Projeto UNISUS 
ganhava o sentido de sua existência e isso não era algo questionável do ponto de vista dos sujeitos envolvidos. Assim, a analogia traçada em relação ao SUS era que ele seria como a natureza, ou melhor, naturalizado a partir de seus próprios princípios. Exemplos dessa naturalização é o fato de o SUS e as políticas de atenção básica que o constituem ser a base primordial sobre a qual o projeto político e pedagógico da Escola Superior de Ciências da Saúde (ESCS) se assentou.

Outra naturalização dizia respeito à novidade do SUS, que começou a ser consolidado no início dos anos 1990 ao mesmo tempo que 10 anos depois o mesmo foi completamente abraçado enquanto base ideológica ordenada para a construção desse projeto educacional do Distrito Federal. Naturalizar o SUS era, na mesma medida, despolitizá-lo, isto é, colocá-lo fora do alcance da intervenção moral ou de qualquer questionamento quanto sua ideologia. Esse sistema, feito de pessoas que ocupam posições e que se politizam em torno de algo que está além delas e que lhes serve como base conceitual inquestionável, é situado discursiva e conceptualmente no campo da irredutibilidade quanto aos seus preceitos e princípios mais básicos; de forma semelhante ao Estado, entidade imaginada que rege a vida política. $\mathrm{O}$ resultado disso é que a base racional é naturalizada pelo ponto de vista institucional era, por analogia, irredutível em si mesma, ou seja, ela era o ponto de partida e o plano fundacional ideológico mais básico do Projeto UNISUS.

Dada uma base ideológica e política naturalizada, a legitimidade do Projeto UNISUS residia na analogia criada entre a Escola Superior de Ciências da Saúde (ESCS) e o Sistema Único de Saúde (SUS). Aquela não existiria sem os princípios ideológicos deste. Na complementaridade entre ensino e serviço, prevista pelo plano pedagógico, foi posta uma relação complexa que se expressava nas bases institucionais da própria Escola. Uma proposta institucional que integra a ideia de uma pedagogia que acontece dentro do sistema público de saúde era feita de relações que aconteciam tanto no nível prático da gestão e administração dessa interação quanto no nível ideológico da proposta pedagógica de formação do "médico total".

Seguindo a perspectiva de Mary Douglas (1986), a mera existência legal da instituição não basta para que haja identificação entre seus membros de maneira coletiva e unificada. Segundo ela, faz-se necessário a existência e o compartilhamento de um "tempo emocional comum" a todos seus membros. Ainda que a visão de que esse "tempo comum" não signifique 
consenso ou unanimidade diante dos processos institucionais, a ideia de um "tempo compartilhado" oferece um patamar comum em que projetos políticos podiam ser discutidos, executados e onde, naturalmente, acontecem tensões e disputas.

É preciso que entre seus membros exista algum pensamento e algum sentimento que se assemelhem. [...] Se o grupo possui algo, é devido à teoria legal que o reveste de uma personalidade fictícia. A existência legal, entretanto, não basta. Os pressupostos legais não atribuem tempo emocional ao grupo que se associa. Somente pelo fato de ser legalmente constituído não se pode dizer que o grupo 'comporta-se' e muito menos que ele pense ou sinta. (Douglas, 1986, 19)

A instituição educacional estudada nesta etnografia estava em um movimento que era de transformação. A configuração do processo institucional abordado oferecia um contexto no qual seus membros se reuniam em arenas políticas propícias para que debates acontecessem. Tive a oportunidade de observar essas relações interinstitucionais e interpessoais em um momento particular que dizia respeito ao processo de transformação que estava em andamento no decorrer da pesquisa de campo. Isso oferecia condições compartilhadas dentro das quais se conjugavam as identidades em um momento institucional comum aos atores sociais envolvidos.

O conceito de "dramatização do mundo social", conforme exposto por Roberto da Matta (1978) na descrição da cultura do "você sabe com quem está falando?” no contex to da sociedade brasileira, é bastante rentável para que se compreenda o sentido das tensões e afinidades coletivas que observei durante o processo de transformação institucional. Esse autor diz o seguinte:

Minha perspectiva é claramente processual [...]. De fato, estou realizando o estudo de
uma transformação social importante do cenário quotidiano, quando a rotina e a
interação social são transformadas em momentos dramáticos e de confronto entre duas
pessoas, grupos ou categorias sociais. Nessa transformação pode-se discernir
claramente alguns aspectos ocultos do mundo social, já que eles são chamados à tona
para atuar como recursos de poder e prestígio junto aos atores implicados na
ritualização. (Matta, 1978, 160-1)

Roberto da Matta (1978) destaca alguns pontos principais que se relacionam com a questão da dramatização social dos posicionamentos e tensões que eventualmente surgem nas relações cotidianas. O primeiro deles é que as situações socialmente dramáticas são frutos de uma situação de conflito entre pessoas ou grupos específicos; o segundo ponto é que nas situações de conflito geralmente há uma oposição entre valores distintos; no terceiro ponto a violência age como um potente recurso para que os lados se definam claramente; o quarto aspecto diz respeito, concomitantemente ao terceiro ponto, que a dramatização é reveladora das 
identidades socais. A perspectiva da "dramatização" de Roberto Da Matta tem contexto específico e está relacionada à análises da sociedade brasileira em que ele dá diversos exemplos de como os conflitos sociais são dramatizados e o que está em jogo em diversos contextos da vida cotidiana. No caso estudado aqui, uma série de valores foram dispostos em arenas políticas de discussão e revelaram certas incompatibilidades entre esses mesmos valores que diziam respeito à relevância dos enquadramentos hierárquicos diante de dimensões diferentes que perpassavam o Projeto UNISUS.

Utilizo ainda a perspectiva de Goffman $(1963 ; 1967 ; 1974)$ quanto à percepção que ambos esse autor tem sobre determinados aspectos das interações cotidianas face-a-face para compreender o sentido das disputas interinstitucionais dentro do processo estudado. Matta (1978) fala do nível da dramatização do poder nas relações face-a-face e nas disposições e posicionamentos sociais que se configuram dentro de determinado processo de transformação social. A criação da UNISUS, no que diz respeito ao modo como os rituais políticos do Estado, foi conduzida em arenas políticas e era expressão daquilo que motivava a vida política institucional e, o modo que as interações face a face aconteceram ao longo do processo, evidenciaram as posições dos atores sociais envolvidos com o processo de transformação. Uma série de conflitos entre atores sociais e institucionais investidos de diferentes graus de autoridade se expressaram através das interações faca-a-face e alguns atos de hostilidade foram cometidos e definiram a identidade e o posicionamento dos atores dentro da arena política de discussão do projeto de lei que criava a UNISUS. Faço uso da perspectiva de Goffman (1963; 1967; 1974) como ferramenta analítica interessante para compreender as interações face-a-face que se deram nos espaços de disputas de poder e alinhamentos políticos em torno de um projeto institucional, que envolveu uma série de atores sociais dispostos em uma longa rede que configurou toda uma arena política que era tanto prática quanto ideológica.

Este capítulo busca discutir etnograficamente o modo como que o projeto da nova universidade foi passando pelas esferas públicas de discussão e deliberação dentro da rede institucional pesquisada para mostrar o sentido das disputas em torno do Projeto UNISUS. Os eventos observados e narrados neste capítulo tratam de uma assembleia; um debate; e uma plenária do Conselho de Saúde do Distrito Federal, todas com a pauta principal sendo o projeto de criação da Universidade de Ciências da Saúde do Distrito Federal (UNISUS). Esses três eventos públicos mostraram o modo com que o Projeto UNISUS se inseriu na arena política 
local. O estudo desse processo foi antropologicamente relevante, pois foi possível mapear as posições sociais, destacar os discursos e as preocupações institucionais quanto a própria forma de existência do projeto educacional e ideológico entre os diversos atores sociais que faziam parte das instituições envolvidas, assim como foi possível aproximar-se etnograficamente da democracia cotidiana que acontecia no controle social das políticas públicas voltadas para a saúde e sua educação no âmbito da administração da vida pública e política do Distrito Federal.

\section{ETNOGRAFIA DE UM PROCESSO INSTITUCIONAL}

Seguindo a mesma metodologia utilizada no capítulo anterior para traçar o histórico de criação da Escola Superior de Ciências da Saúde (ESCS) e da Fundação de Ensino e Pesquisa em Ciências da Saúde (FEPECS) com base em documentos e atas de reuniões compilados em um dossiê oficialmente publicado pela própria instituição, neste capítulo, para falar do processo de criação da Universidade de Ciências da Saúde do Distrito Federal (UNISUS) não fiz diferente.

Tendo visto que a UNISUS não existia ainda como uma instituição em si, mas que uma grande quantidade de coisas já foram publicadas a seu respeito, montei um dossiê sobre a criação da UNISUS por conta própria. Ainda, e de forma alguma menos importante, provenientes do diário de campo, tenho os relatos detalhados de três eventos públicos oficiais que aconteceram na escola em torno do Projeto UNISUS, os quais compõem o fio etnográfico e analítico dorsal deste capítulo. A relevância da etnografia em torno do processo institucional que descrevo e analiso neste capítulo se pretende manifestadamente contributiva para a compreensão do modo como que esse projeto público do Estado foi conduzido nas esferas da democracia participativa e do controle social em saúde. A etnografia desse processo permite transcender a perspectiva documental silenciadora que será criada depois da concretização da universidade, cujos documentos oficiais formaram o eixo analítico do capítulo anterior. $\mathrm{O}$ silenciamento do ponto de vista documental não narra como foram as discussões referentes às atas de reunião, por exemplo, e menos ainda como aconteceram as deliberações em torno do projeto de lei. A tendência geral das instituições é normalmente silenciar as discussões internas em prol de maior formalismo e diretividade sucinta dos documentos oficiais com a finalidade de registrar o que foi decidido, mas não narram o processo no qual foram tomadas as decisões 
e deliberações, ainda que as discussões em si possam informar bastante sobre o posicionamento dos atores envolvidos, o nível de interesse dos que estavam presentes, e também outras informações antropologicamente interessantes.

Foi apenas fazendo uma etnografia do processo de transformação institucional mediante o acompanhamento das reuniões e dos debates nos quais os atores institucionais se encontravam que foi possível compreender o sentido das disputas em torno do projeto público de transformação que estava acontecendo no campo da educação médica no Distrito Federal porque, quando finalizado o processo de criação da nova instituição, isto é, da Universidade de Ciências da Saúde do Distrito Federal (UNISUS), o percurso e as especificidades que caracterizaram o processo de criação poderão ser silenciados na medida em que forem encerrados nos formalismos dos dossiês institucionais oficiais, herméticos na auto representação das imagens históricas e omissos na narração de seus processos sociais mais axiomáticos que qualificam seus processos. Documentos institucionais oficiais (atas, regimentos, leis, manuais) não capturam a complexidade do processo de transformação institucional em si, que é repleto de ampla variedade de vozes que propagam seus valores e interesses dentro de um ambiente que é público e político no qual os diversos atores sociais tomam posições revelam os limites entre um projeto público e sua execução. Portanto, para além da história da instituição de ensino à qual dou atenção no que concerne aos fatos eternizados documentalmente conforme a cultura dos dossiês, delimitada e limitada, para que se compreenda esse determinado processo social, o intuito aqui é dar vida às posições dos diversos atores conforme entram em disputas para dar movimento e vida àquilo que os documentos oficiais não dão.

\section{O PROCESSO UNISUS}

Sigo com a análise de três eventos de forma cronológica e em sequência porque eles ganham significado apenas se analisados em conjunto. Mais uma vez, o primeiro evento que analiso aconteceu no dia 15 de agosto de 2013 e foi uma assembleia na qual foi apresentado para o corpo geral de pessoas da FEPECS - entre elas, estudantes dos cursos de medicina e enfermagem, docentes e servidores vinculados à fundação - o projeto de criação da UNISUS. O segundo evento aconteceu no dia 01 de outubro de 2013 e foi um debate com os interessados 
no projeto de lei de criação da UNISUS, que fez parte de um chamada pública com vista à fazer esclarecimentos e ajustes no projeto de lei. E o terceiro evento aconteceu no dia 15 de outubro de 2013, o qual foi uma reunião da plenária do Conselho de Saúde do Distrito Federal (CSDF) na qual se deliberaria sobre pontos específicos no projeto de lei da criação, mas devido a embates e disputas políticas que eclodiram durante a plenária e a inviabilizaram, ela foi cancelada e, até o momento, o Projeto UNISUS se recolheu a portas fechadas, desacelerou suas discussões públicas e foi silenciado nas arenas do controle social das políticas de saúde, e tal silenciamento possibilitou uma análise crítica aos processos da democracia participativa em nossa sociedade e ao modo como o projeto da nova universidade foi sendo conduzido ao longo do seu processo.

\section{“É PROJETO POLITIQUEIRO"}

Era 15 de agosto de 2013, por volta das cinco horas da tarde no auditório maior da Escola Superior de Ciências da Saúde (ESCS). A assembleia para a apresentação do projeto não havia começado e os estudantes estavam se organizando para sentar. Não havia muitas pessoas no auditório e elas estavam dispersas em pequenos grupos ou individualmente nas cadeiras do auditório. Os primeiros que chegaram, na sua maioria, eram estudantes. O cuidado para que se sentassem uns pertos dos outros era grande e muito significativa. Mais estudantes chegavam, e chegavam trazendo cartazes, se aglomerando ao fundo do auditório. Eles começaram a grudar os cartazes nas paredes do auditório e se organizando para sentar.

Os cartazes traziam mensagens, como "Cadê a sala de repouso dos internos no HRT (Hospital Regional de Taguatinga)?”; “Cinco anos de campus provisório. Até quando?”; "Na ESCS aprendi a nadar. Choveu alagou"; "RU? Queremos primeiramente copos.”, este com dois copos descartáveis colados no cartaz. Outros faziam demandas mais direcionadas, como "Cadê? Laboratórios? Cadeiras? Livros? Falta tudo!"; "Investimento em pesquisa!"; "Carreira de docente já!”. E provocações auto afirmativas, como "Quem estuda também luta.”; "Quarta melhor do Brasil? Até quando?”. E a que era mais enfática e numerosa: “Queremos autonomia!". Os cartazes não diziam respeito apenas à UNISUS, olhando para o fato que o evento era para a apresentação do projeto da nova universidade. Os estudantes viram, nesse evento, uma oportunidade para apresentar reivindicações sobre a Escola Superior de Ciências 
da Saúde (ESCS) visto que as mensagens nos cartazes não falavam da UNISUS diretamente, mas falavam das faltas que hoje existem na instituição na visão deles.

Entre a chegada de umas dezenas de estudantes e a colagem dos cartazes pelas paredes do auditório se passaram cerca de dez minutos. Com alguns dos estudantes já sentados, outros professores chegaram e alguns servidores da escola também. Eu soube distinguir de que categoria eram as pessoas porque na medida em que estas pessoas chegavam, eu perguntava aos estudantes quem eram, o que foi criando legendas em um mapa mental que eu fiz das disposições das pessoas no auditório. Me sentei ao fundo para que pudesse ter uma visão geral das pessoas dentro do auditório. Isso fez com que eu pudesse destacar reações coletivas conforme a assembleia acontecia. À mesa do auditório estavam a diretora executiva da FEPECS e a coordenadora do curso de medicina. Elas foram quem fizeram a apresentação do projeto ao público presente. O auditório estava metade cheio sendo, cerca de 100 pessoas ou mais, a maioria eram estudantes, depois professores e em menor quantidade alguns servidores e funcionários da FEPECS e da ESCS.

A assembleia teve uma apresentação de slides em projetor que foi o foco do evento. $\mathrm{O}$ título da apresentação era: "Projeto UNISUS: Onde estamos? Para onde vamos?". Prestei atenção na ordem com que o conteúdo na apresentação do projeto foi disposta pois ele revelou características importantes sobre o modo como a instituição se referia a si mesma, isto é, ao processo tanto histórico quanto atual de seus desdobramentos.

O conteúdo da apresentação foi o seguinte: Iniciou-se com uma "contextualização do momento", cujos tópicos eram, primeiro, “debater a proposta de criação da UNISUS, construída ao longo de um ano e três meses" e segundo, "ouvir, trabalhar tecnicamente, trabalhar politicamente". O segundo slide era intitulado "histórico do movimento" e trazia, em tópicos, um histórico da instituição focado nos momentos mais recentes, apenas mencionando o fato de que em 2013 a ESCS fez 12 anos de história e os tópicos seguintes diziam o seguinte:

2012, março/maio: nomeação das [novas direções]; 2012, maio: criação do colegiado de gestão da FEPECS; 2012, agosto: debates internos: 'FEPECS em Mudança; e Reuniões (estudantes, docentes, servidores); 2012, setembro: Plano de Saúde da SESDF 2012-2015; 2012, dezembro: Resolução do Conselho de Saúde do DF; 2013, 20 de março: GT de criação da UNISUS, [até] 24 de junho. (Capitani e Teodoro, 2013)

Não cabe destrinchar detalhadamente cada um dos pontos trazidos no histórico institucional feito durante a apresentação, contudo, julgo válido olhar para todos estes pontos 
como vetores de um processo único, a transformação do ensino médico traduzido nos planos do governo local. No mesmo ano, isto é, em 2012 foi publicado pelo GDF o Plano Distrital de Saúde da Secretaria de Saúde do Distrito Federal de 2012-2015 ao mesmo tempo em que debates internos à FEPECS começaram a visar sua própria mudança interna e remanejamento administrativo. O processo institucional partiu da existência histórica da escola, passando diretamente ao momento atual em que uma nova direção fora nomeada, um novo colegiado de gestão foi criado e um novo projeto começou a ser discutido por um grupo de trabalho responsável pela transformação institucional da ESCS em UNISUS.

A criação da UNISUS já era prevista pelo Plano Distrital de Saúde da Secretaria de Saúde do DF de 2012-2015, conforme trago um trecho que, por mais longo que seja, traça as diretrizes e estratégias na gestão na educação em saúde e justifica a criação da UNISUS:

Importante desafio para a consolidação do SUS se encontra na formação e desenvolvimento profissional capazes de produzir trabalhadores com perfil adequado às necessidades do Sistema de Saúde. O Distrito Federal não é exceção, mas conta com o diferencial de ter, vinculada à Secretaria de Estado de Saúde, a Fundação de Ensino e Pesquisa em Ciências da Saúde - FEPECS [...]. Entretanto, muitos desafios devem ser enfrentados para o aprimoramento da FEPECS com vistas à sua missão institucional. Quanto à ESCS, a estrutura provisória de que a Escola foi suprida, em 2001, [...] foi, ao longo do tempo, dando sinais de esgotamento. Graves problemas estruturais vêm se tornando cada vez mais complexos, entre eles, a inadequação das atribuições da mantenedora estabelecida pela lei de criação desta fundação.

Um segundo problema estrutural está nas dificuldades de criação e gestão da carreira docente da ESCS, da ETESB e da própria SES, tendo em vista suas peculiaridades metodológicas e de inserção profunda no mundo do trabalho e o imprescindível olhar sobre a preceptoria da graduação e das residências, também como função docente. A caracterização do corpo docente da ESCS/ETESB/SES deve dar-se mediante duas lógicas articuladas: na lógica vigente, em regime de dedicação parcial ou integral, pertencentes ao quadro próprio das escolas e na lógica da Integração Ensino-Serviços, que impõe que o corpo docente não pode ser outro senão composto por servidores próprios de saúde, atuando na docência enquanto exercem sua função assistencial. [...]

O terceiro problema trata do modelo político de gestão da FEPECS. A gestão participativa é um modelo que está previsto na legislação da saúde e também da educação e que deve ser orientadora para toda a execução da agenda estratégica da FEPECS, bem como de todos os seus setores. A Gestão Democrática na área de educação possui vários elementos constitutivos: autonomia acadêmica; descentralização do poder; representatividade social dos conselhos e colegiados; controle social da gestão educacional; escolha dos dirigentes por processo de consulta pública à comunidade acadêmica e Plano de Desenvolvimento Institucional, que precisam todos ser discutidos e implantados. A sustentação e a melhoria contínua do desempenho da FEPECS, suas escolas mantidas e setores, exigem a reformulação da política de formação e desenvolvimento profissional de saúde da FEPECS com a SES, com fortalecimento da integração ensino-serviço, por meio de seis projetos que devem ser trabalhados conjuntamente: [...] vislumbrando com tudo isso a transformação da Escola Superior de Ciências da Saúde em Universidade Especializada na Área de Saúde. (GDF, 2012, 55-6) 
Fazendo menção à necessidade de formação de profissionais adequados a atenderem às necessidades do SUS e à positividade da existência da FEPECS e da ESCS no âmbito do sistema de saúde do Distrito Federal, a disputa de interesses entre as duas foi citada pelo documento como "inadequação das atribuições" e suscitou que havia conflitos, mas não disse quais especificamente. Outro problema apontado era que havia a necessidade de criação de carreiras docentes na SES-DF. As tensões em torno dessa questão estava no posicionamento de atores que, de um lado, diziam que a docência seria uma forma de "canibalizar" o sistema de saúde por retirar profissionais do serviço assistencial para atividades acadêmicas, ao passo que, de outro lado havia aqueles que dizem que, pelo lado da metodologia, à qual dei ênfase no capítulo anterior, estaria colocando, à médio e longo prazo, novos médicos formados dentro de um processo pedagógico inovador que a própria ESCS provê. Discuto isso à fundo mais à frente. E o terceiro ponto feito no Plano de Saúde do Distrito Federal em 2012, "vislumbrando a criação da universidade", unia a questão do controle social na gestão democrática dentro do processo de transformação institucional, valorizando o modelo político de gestão do sistema de saúde público brasileiro.

É possível perceber a essência daquilo que deu início ao processo de criação da Universidade de Ciências da Saúde do Distrito Federal (UNISUS). Primeiro um conflito de interesses; segundo a questão da docência médica nas instâncias do Estado; e terceiro a democracia participativa específica da saúde. A conjunção desses três pontos apontava a direção para a qual o processo fora iniciado.

Continuando com o conteúdo da apresentação do projeto, o slide seguinte era intitulado "Chegando à UNISUS" e fazia ode ao projeto e às instituições com os seguintes tópicos:

Única universidade no Brasil pertencente à estrutura de uma Secretaria de Estado de
Saúde; criada a partir da exitosa experiência da ESCS na formação médica (3 vezes
nota máxima ENADE e reconhecimento de qualidade pelos profissionais de saúde) e
de enfermagem (ENADE para os ingressantes acima da média nacional) e das
experiências de 52 anos da ETESB e de 40 anos da [EAPSUS] na formação técnica e
na educação permanente; profunda integração entre a educação e pesquisa e os
serviços da SES-DF [...]. (Capitani e Teodoro, 2013)

O slide terminava com a seguinte equação: "ESCS + ETESB + [EAPSUS] + serviços administrativos da FEPECS = UNISUS". "Passos importantes!" era o que dizia o próximo slide. Quanto às questões executivas, a diretora da FEPECS, que estava apresentando o projeto, disse que havia "apoio político e técnico da SES-DF" assim como "apoio do governador", dizendo 
que ele falou o seguinte em junho de 2013: "Vamos inaugurar a UNISUS no segundo semestre. Preparem tudo." A fala estava transcrita no slide.

Quanto ás questões legislativas, o projeto deveria ser enviado à Câmara Legislativa do Distrito Federal (CLDF), cujo "apoio declarado dos deputados: Arlete Sampaio, Cláudio Abrantes, Chico Leite e Israel Batista" foi evidenciado com determinada ênfase, dando a entender que os caminhos políticos e burocráticos dos níveis maiores do governo local estavam abertos ou, pelo menos, assegurados por algumas figuras políticas nas instâncias institucionais legislativas da gestão pública local.

Além disso - chegando aos pontos que geraram mais polêmica entre os atores envolvidos, conforme veremos logo mais à frente -, os seguintes pontos foram expostos nos slides seguintes:

\begin{abstract}
O secretário de saúde continua presidindo o conselho deliberativo da FEPECS; um reitor será o presidente da FEPECS [...]; gestão democrática com colegiado em todos os níveis, com participação de gestores da saúde; consulta pública à comunidade acadêmica [...]; corpo docente constituído de servidores da SES-DF; criação do centro de formação de docentes e preceptores; [...]. (Capitani e Teodoro, 2013)
\end{abstract}

Vejamos que, na visão das diretoras da FEPECS e da ESCS, atores que redigiram a apresentação do projeto, mantida a FEPECS, o secretário de saúde continuaria presidindo a FEPECS e seria criado o cargo de reitor, que não existia. O cargo maior na ESCS era a diretoria, subordinada à diretoria da FEPECS, por sua vez, subordinada à presidência desta mesma instituição, ocupada pelo secretário de saúde. Com a criação da UNISUS, as diretorias das escolas se extinguiriam e dariam lugar à função do reitor, o qual, em tese, estaria mais próximo do complexo educacional ao centralizar sob sua égide administrativa escolas que antes tinham diretorias independentes. Estudantes, docentes e as próprias diretoras das escolas tem interesse na criação do cargo de reitor caso a universidade seja criada, mas quando o projeto chegou nas arenas do controle social da saúde pública, a questão da gestão do projeto universitário se mostrou repleta de conflitos, de tensões e de alinhamentos característicos do modelo democrático e participativo da gestão da saúde.

Olhando para o futuro, os últimos slides da apresentação do projeto vieram como “Perspectivas 2013", prevendo uma

solenidade de assinatura pelo Governador do Projeto de Lei alterando a lei de criação da FEPECS criando a UNISUS; alterações na Lei da Gratificação de Atividade de 
Ensino (GAE); criação da Lei de Gestão Democrática da UNISUS; e consulta pública à comunidade acadêmica [...]. (Ibid.)

E também trouxe "Perspectivas 2014-2017" prevendo:

\begin{abstract}
Reforma curricular dos cursos de graduação; criação do quadro de pessoal próprio da FEPECS/UNISUS; ampliação da infraestrutura das unidades Asa Norte e Samambaia; proposta de duplicação das vagas de medicina, criação da terceira graduação e de pósgraduação stricto sensu até 2015, [...]; fortalecimento da infraestrutura de educação e pesquisa [...]; fortalecimento das residências como mecanismo de formação especializada em saúde; qualificação das preceptorias de graduação e residências; implementação da educação permanente em serviço como instrumento de gestão e melhoria do processo de trabalho; ampliação e fortalecimento do ensino técnico e póstécnico; criação da função docente pesquisador nas carreiras de nível superior da SESDF. (Ibid.)
\end{abstract}

Encerrando, enfim, com "encaminhamentos" para a

finalização do projeto UNISUS; divulgação das minutas dos projetos de lei de criação da UNISUS; lei alterando a lei de criação da FEPECS criando a UNISUS; [...] preparação para solenidade de assinatura do projeto de lei criando a UNISUS. (Ibid.)

Depois da apresentação do projeto e de seu discurso bastante político e explicitador das alianças existentes em torno do Projeto UNISUS e dos valores manifestos nele, a diretora da FEPECS apresentou uma camiseta, esta que ela disse que seria "como o novo uniforme da UNISUS" e que queria "ver todos vestindo esta camisa a partir do ano que vem", no "momento em que a ESCS se tornaria UNISUS”. Era uma camiseta branca com a nova marca da UNISUS, que trago mais à frente na Foto 4.

No momento em que a camiseta foi mostrada, um murmúrio surgiu dentro do auditório. As pessoas cochicharam, fizeram sons de desaprovação em tom baixo, como "vish" ou "pelo amor de deus" ou "fala sério", pude escutar e ver. As pessoas, principalmente os estudantes, se remexeram em suas cadeiras, cochicharam uns nos ouvidos dos outros. Apesar dessas expressões de desaprovação, quando as camisetas foram confeccionadas e distribuídas, foi possível ver muitas pessoas da ESCS e da FEPECS usando a camiseta, inclusive os estudantes, o que deu a ideia de que os sinais de desaprovação foram mais uma maneira de manter uma determinada pressão sobre a diretoria do que uma desaprovação veementemente categórica. Os sinais de crítica conotaram um dos aspectos da opinião geral que os presentes na assembleia tinham sobre o projeto e sobre o modo com ele se desenvolvia naquele momento específico. Como os presentes na reunião eram internos às instituições e ainda, em sua maioria eram estudantes, a incitação da diretora para que a camisa fosse vestida parecia constranger os estudantes. Considerando que tanto os estudantes quanto as diretoras apoiavam o projeto da 
universidade e houvesse alinhamento entre esses dois grupos em torno da criação da nova universidade, naquele momento, a ideia de "vestir a camisa da UNISUS" soou exagerada, levando em conta a concordância que já existia entre esses dois grupos no contexto interno da Escola Superior de Ciências da Saúde (ESCS). Desse ponto de vista, num primeiro momento, o gesto de desaprovação quanto ao vestir a camiseta fazia sentido porque ali já se compartilhava certa uniformidade quanto à proposta de criação da nova universidade e uma incitação à ênfase dessa configuração pareceu ter sido vista como exagero naquele momento. Todavia, tempos depois, quando as camisetas foram confeccionadas, muitos dos estudantes as vestiram em várias ocasiões, principalmente quando atores externos à Escola estavam presentes. Isso seria uma maneira de impressionar politicamente outros atores sociais nas esferas de discussão pública externos à instituição, com vistas à incitar a opinião deles positivamente em relação à criação da nova universidade. $\mathrm{O}$ que quero dizer é que a reação negativa inicial à ideia de "vestir a camisa da UNISUS" frente o fato de que os estudantes as vestiram depois pode não ser uma contradição, pois apenas no momento da apresentação do projeto da futura universidade pareceu ser um excesso, mas frente à atores externos, "vestir a camisa" da nova universidade era motivo que evidenciava uniformidade institucional e posicional quanto à ESCS à futura UNISUS.

Terminada a apresentação do projeto e da camiseta, chegou o momento das perguntas da plateia e a palavra foi passada primeiro para representantes dos corpo estudantil. Primeiro uma estudante do curso de graduação em enfermagem fez uma lista de perguntas ao microfone, perguntando primeiro "onde estão sendo implementados os recursos que o governo esta inserindo dentro da FEPECS", uma vez que a estrutura seria muito incipiente para que haja a construção de uma universidade? Segundo, "aonde estão os fundos para assistência" estudantil? Porque "muitos estudantes de outras cidades vieram a Brasília para fazer o curso, e tem passado dificuldades" com a pouca assistência oferecida. Terceiro, "onde está o restaurante universitário? Os estudantes pagam 25 reais no restaurante a quilo do outro lado da rua, por dia, porque não existe restaurante dentro da FEPECS, só uma lanchonete pequena" que não atende à demanda. Quarto, como haverá ampliação de vagas para estudantes se não existe estrutura e nem docentes suficientes para dar aulas para tanta gente? Ingressam 80 alunos por ano e os planos para o Projeto UNISUS é aumentar este número, dobrando-o, conforme a apresentação da diretora. A estudante disse que "se é para aumentar o número de vagas, que se aumentem as condições também", completando que um aumento no numero de vagas implicaria num 
aumento da qualidade e quantidade da estrutura física da escola, das salas de aula, dos laboratórios e completou dizendo que "seria uma imprudência aumentar o numero de vagas na situação em que a ESCS se encontra”.

As diretoras da FEPECS e da ESCS ganharam a palavra novamente. Primeiro quem teve a fala foi a diretora da FEPECS. Disse que "a atual lanchonete e um futuro restaurante universitário estão sujeitos à vigilância sanitária para estarem dentro da legalidade", e que "a criação da UNISUS está sendo feita e deve ser feita dentro da legalidade", mas que, para isso, necessita de mais investimentos para a construção de um novo restaurante, o que "faz parte dos planos", mas que essa não era a prioridade naquele momento. Prosseguindo com sua fala, disse que o GDF investiu dinheiro no projeto da FEPECS recentemente através do plano para a saúde feito pela SES-DF durante o mandato do governador Agnelo, como citei logo mais acima um trecho do plano, mas que "muito desta verba foi utilizada para a construção do prédio novo", construído por volta de 2008. Disse, em seguida, reconhecer que uma estrutura de funcionamento melhor precisaria ser feita para que a nova universidade fosse concretizada, pedindo "mais tolerância e limite das demandas dos estudantes frente ao atual investimento feito pelo GDF na FEPECS e pela FEPECS no projeto UNISUS”. Consecutivamente, a diretora da FEPECS passou a fala para a diretora da ESCS, que pediu cuidado da parte dos estudantes para "não tentarem resolver questões complexas através de meios simples porque isso levaria a maiores problemas no futuro", completou, dura. Disse que do ponto de vista do GDF e dos programas políticos públicos à SES-DF, cujos investimentos estavam divididos entre a FEPECS e o SUS, isto é, entre ensino e serviço, a díade primordial do Projeto da ESCS e da UNISUS, o que estavam tentando fazer era "tornar esta vinculação mais concreta", por isso a premeditada mudança do nome da ESCS para UNISUS, ao exaltar o projeto como uma "inovação" e um "avanço" da gestão da Escola ao "ampliar o acesso dos estudantes ao mercado de trabalho" com mais efetividade, por causa mesmo da estrutura curricular e do projeto pedagógico que pressupõe tudo isso, ela disse. Não houve tréplica por parte de ninguém e a fala foi entregue à outras pessoas presentes.

Percebam-se as forças. A estudante, falando em nome do corpo discente como um todo perante as figuras dirigentes da FEPECS e da ESCS, que estavam apresentando o projeto, queixou-se das "faltas" quanto à assistência estudantil (investimentos) e infraestrutura física da escola (restaurante, laboratório, salas de aula) e criticou a questão da ampliação de vagas caso 
a estrutura atual permaneça do mesmo tamanho e com a mesma capacidade. De outro lado, as diretoras responderam parecendo dar maior atenção aos aspectos políticos e relacionais no tocante ao andamento político do Projeto UNISUS do que aos caracteres mais intrinsecamente presentes na vida cotidiana dos estudantes no que diz respeito aos processos formativos em si, falando mais do cumprimento do plano distrital de saúde do que das reivindicações feitas pela estudante, pedindo condescendência por parte dos outros estudantes.

Seguindo, a fala foi a de um professor da Escola Superior de Ciências da Saúde (ESCS) que parecia ser a favor da transformação institucional conforme o projeto havia sido recém apresentado. Ele disse que "a associação e integração da escola com o SUS ainda é uma ideia, um projeto ainda no papel", sugerindo que existia descompasso entre o que dizia o projeto e o que poderia ser efetivado na prática, afirmando que todos deveriam levar isso em conta, tanto estudantes quanto as diretorias. Seguiu sua fala mencionando o seguinte:

\footnotetext{
Existe atualmente uma crise da educação médica no Brasil que vem sendo historicamente definida e que coloca muitos desafios para a educação e para a saúde do país. Algumas coisas devem ser consideradas nesse movimento aqui: primeiro, essa instituição é uma instituição inovadora em ciências da saúde que por si a coloca em um patamar diferenciado; segundo, o currículo como ele é hoje segue nesse sentido, tendo a prática médica abrangendo todas as quatro áreas da ciência médica (obstetrícia e ginecologia, clinica, pediatria e cirurgia) e ainda tendo uma vinculação direta com a saúde coletiva, o que vai muito além dos demais cursos de medicina no DF; terceiro, o projeto implica uma via de dois fluxos entre o sistema publico de saúde e a escola, o que, por si só, agrega valores éticos, morais e de compromisso com a educação e a saúde no Brasil; quarto, completou dizendo que a raiz do problema é que o modelo biomédico de ensino não prepara o profissional para a realidade complexa da saúde no Brasil. (Professor da ESCS. Fala registrada em diário de campo, $15 / 08 / 2013$ )
}

Ele terminou sua fala pedindo ainda aos estudantes que não confundissem "autonomia" com "soberania" frente às demais instituições vinculadas ao Projeto e à outras faculdades de medicina de Brasília, dando a entender que ele estava mencionando a questão de que a ESCS, instituição de ensino superior, ao longo de sua história foi ocupando espaço político preponderante frente às outras instituições mantidas pela FEPECS, como a ETESB e a EAPSUS, como se tivesse passado a fazer sombra sobre elas na medida com que se expandiu, colocando suas demandas mais imediatas na frente das demandas da outras escolas da mesma rede. 
Quando o professor terminou sua fala, um estudante vinculado ao centro acadêmico de medicina CAMIB, perguntou, incisivo e exaltado, usando mais ou menos essas mesmas palavras e ideias:

Como é possível falar de moral e de valores éticos com todas as faltas que a gestão da escola tem? Olhem para o curso de enfermagem. A situação dos estudantes no campus de Samambaia é imoral e vocês vem nos falar de valores éticos? Do ponto de vista pedagógico falta uma estrutura melhor do organograma do curso que cumpra com as proposições do projeto de criação da UNISUS, mas com a estrutura de hoje isso está longe de acontecer. Na ESCS a formação médica ainda está muito vinculada à indústria médica e ao modelo hospitalocentrico ao qual qualquer curso de medicina por ai é vinculado. O CAMIB rejeita a criação de novas vagas por causa da gestão precária da saúde no DF por parte do próprio GDF. Em nome dos estudantes da ESCS a gente se recusa a se tornar massa de manobra de projetos políticos do governo Agnelo só porque ano que vem é ano de eleição. O projeto UNISUS não passa de uma jogada política do governo atual, porque se vermos a estrutura FEPECS ela não comporta um projeto tão grandioso quanto vocês estão dizendo. (Estudante de medicina. Fala registrada em diário de campo, 15/08/2013)

Uma salva de palmas e assovios feitos pelos estudantes finalizavam cada ponto feito por este estudante na mesma medida em que ele falava. $\mathrm{O}$ clima dentro do auditório ficou desassossegado. Enquanto ele falava, a cada ponto que expunha o restante dos estudantes batiam palmas, exaltavam os ânimos, concordavam e davam apoio. Bateram palmas fortes cerca de cinco vezes enquanto falava, com assovios, gritos e palavras de incentivo. O estudante continuou:

\begin{abstract}
Aonde estão as carreiras docentes? Porque a ESCS ainda não tem plano de carreira profissional para os professores e um dos pontos do projeto UNISUS, conforme a gente viu na apresentação, é a criação da função docente. Essa falta específica é estruturante da escola e a ampliação do projeto não tem base interna para funcionar como o projeto prevê. [...] A FEPECS, se não prestar atenção, vai ser cada vez mais massa de manobra para a campanha do PT no ano que vem, e a UNISUS é um laboratório eleitoreiro do governo. [...] E para que a gente vista a camiseta da UNISUS no ano que vem, ainda falta fazer muita coisa. (Estudante de medicina. Fala registrada em diário de campo, 15/08/2013)
\end{abstract}

Depois da fala desse estudante, no mesmo nível de crítica, um outro estudante, também envolvido com a representação dos estudantes através do centro acadêmico falou o seguinte:

Qual o tipo de relação que existe entre o GDF e a direção da ESCS, sendo que o GDF tem atuado junto à secretaria de educação e com a secretaria de saúde, mas que ainda assim, na prática, os estudantes da ESCS não estão se sentindo inseridos no SUS ao concorrerem com outras faculdades de Brasília por espaço dentro dos hospitais nos internatos e programas de residências. É comum os estudantes da ESCS chegarem aos hospitais para fazer internato e não conseguem entrar naquela parte do hospital ou fazerem suas atividades porque naquela área do hospital já existe um preceptor de algum curso de outra faculdade qualquer coordenando atividades de outros estudantes de outras faculdades, ou não tem uma sala de descanso sequer, prejudicando o 
andamento do fluxo curricular. (Estudante de medicina. Fala registrada em diário de campo, 15/08/2013)

Criticando a ligação entre as camadas políticas e as camadas práticas do processo de transformação institucional como um todo, foi disposta uma série de denúncias quanto às estruturas da Escola. Criticou-se a gestão dos processos pedagógicos conforme o projeto previa. Criticou-se a gestão política da questão no contexto do SUS, que, apesar de ideologicamente emblemático das políticas estatais para a saúde, parecia distante da realidade dos projetos de valorização da saúde através do Programa Saúde da Família e da atenção básica ao não criar meios eficazes de fazer a interface entre a Escola e o SUS, gerando uma série de problemas quanto à gestão dos processos pedagógicos, que vão ao encontro das relações de poder e estruturas de relações institucionais do Estado. Criticou-se a criação da UNISUS parecer ser tão imediata tendo visto a pouca estrutura existente na ESCS. O estudante disse ainda:

Precisamos de bolsas de estudo decentes e é por isso na escola não faz pesquisa num
nível exemplar, apesar da escola ter sido avaliada como a quarta melhor faculdade de
medicina do Brasil segundo o ENADE, os laboratórios são inadequados para um curso
de medicina e não existe possibilidade alguma de os estudantes fazerem pesquisas de
ponta aqui na escola. O módulo de Interação Ensino-Serviço-Comunidade (IESC) é
um desserviço com os estudantes de medicina, um pela quantidade de deslocamento
necessário para comparecerem nas atividades e dois porque esta parte do curso é mal
trabalhada pela falta de estrutura própria do SUS. [...] Os estudantes não se sentem
seguros nos internatos pela falta de treinamento em laboratórios adequados e o
internato foge, e muito, do modelo pedagógico proposto pela escola e pelo projeto
UNISUS. Faltam estruturas de sala de aula, de biblioteca, de laboratórios, de
condições para que os alunos estudem e exerçam a medicina com dignidade.
(Estudante de medicina. Fala registrada em diário de campo, 15/08/2013)

É preciso mencionar contexto específico em que as críticas estavam sendo dispostas. Aquele era um ambiente público de discussão, dentro de um auditório organizado para que o projeto da nova universidade fosse apresentado e debatido entre os presentes e onde a grande maioria era interna à FEPECS e à ESCS. De um lado estavam as diretoras apresentando o projeto e de outro vinham os estudantes com as críticas. Era de interesse dos estudantes que o Projeto UNISUS fosse efetivado, no entanto, que o mesmo fosse efetivado uma determinada maneira. Os estudantes queriam que fossem supridas determinadas demandas e necessidades inerentes aos processos de aprendizagem, tais como: melhorias em condições infra estruturais; maior investimento na vida estudantil; melhorias na qualidade política da relação entre a ESCS e o GDF no que dizia respeito tanto à relação entre as instituições durante o processo de aprendizagem e à autonomia de gestão das questões internas à Escola, tais como a infra estrutura. As críticas não se dirigiram apenas ao Projeto UNISUS em si, mas se armaram de 
reivindicações quanto à viabilidade dos processos pedagógicos conforme o projeto previa idealmente e à qualidade da relação política que a instituição tem com o governo local.

Interessa notar o fato de que os estudantes viram no momento de apresentação do Projeto UNISUS uma oportunidade extraordinária para discutir questões internas à Escola Superior de Ciências da Saúde (ESCS) e fazer reivindicações quanto à sua gestão no que dizia respeito à infra estrutura e relações políticas que a envolviam. Na medida em que as críticas dos estudantes foram sendo colocadas, a assembleia se revelou como um espaço singular e excepcional para a que a expressão ordenada das preferências e disputas fosse definindo a posição dos atores institucionais diante, não apenas do projeto da nova universidade, mas também a aspectos cotidianos da vida estudantil já existente e que mereceriam mais atenção do ponto de vista do corpo discente. Quanto ao Projeto UNISUS em si, as acusações de que o mesmo estava sendo veiculado com demasiada celeridade e sem levar em conta os aspectos estruturais e assistências da vida estudantil, era fator de desconfiança por parecerem vir em prol dos planos estratégicos do governo com vistas à corrida eleitoral e campanha para o ano seguinte. É válido notar que os estudantes aproveitaram a oportunidade de apresentação do projeto da nova universidade para reivindicar outras questões, isto é, outras demandas internas à Escola Superior de Ciências da Saúde (ESCS) e buscaram acrescentá-las na agenda dos dirigentes. A fala da estudante explicitou a desconfiança quanto o projeto da universidade levando em conta as faltas que a ESCS tinha no momento e tal ceticismo quanto à proposta vinha com acusações de que o Projeto UNISUS estava se dando de uma forma um tanto quanto apressada demais. A sobreposição do processo de criação pouco tempo antes do início dos processos eleitorais de 2014 foi motivo de desconfiança por parte os estudantes e de algumas pessoas que trabalhavam na instituição. A pressa pela transformação da Escola em Universidade, somada às faltas estruturais e de gestão existentes, abriam espaço para acusações, por parte do corpo discente principalmente quando alguns disseram que "é projeto politiqueiro" ou que não passava de uma jogada do governo atual para angariar votos para as eleições no ano seguinte, fazendo a ESCS virar objeto de manobra política para fins estratégicos da política local. 
Seguindo com a narrativa da assembleia, depois da fala dos dois estudantes, um outro homem tomou a palavra, agora um servidor ${ }^{8}$ da ESCS, e ele disse o seguinte:

\begin{abstract}
O momento presente é um momento histórico para a FEPECS e implica em uma mudança de paradigmas que caminha em direção ao futuro. A conjuntura atual da instituição contribui para o fortalecimento do SUS e a UNISUS, como uma universidade, traria mais infraestrutura para o próprio sistema de saúde como um todo, visto a vinculação da escola, da universidade, com o sistema publico de saúde do DF. O que temo é que não pode continuar existindo o canibalismo entre a FEPECS e o SUS, porque retiram-se médicos da rede para colocarem eles nas salas de aula, gerando um desfalque no serviço público. (Servidor da ESCS. Fala registrada em diário de campo, 15/08/2013)
\end{abstract}

Existem membros das instituições, em grande parte servidores da FEPECS e da ESCS, assim como alguns conselheiro de saúde, que acreditam que a ESCS retira muitos médicos do serviço de saúde para atuarem como docentes e que isso geraria um déficit de médicos no sistema de atendimento público de saúde. O termo "canibalização" era o mais usado para se referir à essa "retirada" de profissionais de saúde do campo da assistência de saúde para o campo do ensino da medicina na Escola. O argumento contrário, tido pela direção, pelos estudantes e pelos professores, é que, em médio e longo prazos, a Escola devolver muito mais médicos para o mercado de trabalho do que retira para coloca-los nas salas de aula.

A Escola Superior de Ciências da Saúde (ESCS) tem ao todo 12 anos de funcionamento até o momento e a duração do curso de graduação em medicina é de seis anos. Até o final de 2013 formaram-se ao todo oito turmas de medicina e isso corresponde, idealmente, ao montante total de 640 médicos formados ao longo de toda a história de funcionamento da Escola, posto que a cada ano 80 novos estudantes ingressaram no curso de graduação em medicina. Os dados estatísticos que apresento a seguir revelam a expressividade estatística da presença dos egressos da Escola Superior de Ciências da Saúde (ESCS) do curso de graduação em medicina no mercado de trabalho do serviço público de saúde do Distrito Federal desde que a primeira turma se formou e responde à dúvida sobre se os egressos da ESCS realmente vão trabalhar no sistema de assistência pública à saúde do Distrito Federal.

Solicitei à coordenação do curso de medicina dados referentes ao número total de formados por turma no curso de medicina desde que a primeira turma se formou e quantos

\footnotetext{
${ }^{8}$ Durante a pesquisa de campo não foi possível saber o cargo específico que este servidor ocupava dentro do contexto institucional.
} 
destes foram contratados pela Secretaria de Estado de Saúde do Distrito Federal (SES-DF) através de dois requerimentos. A coordenação deu retorno e informou a quantia de estudantes que se formou em cada turma, mas não me passaram dados referentes àqueles que teriam sido contratados pela SES-DF. Solicitei à Escola também os nomes completos dos estudantes que se formaram para que, em contraste com o banco de dados dos servidores públicos do Governo do Distrito Federal (GDF) ${ }^{9}$, fosse possível ter acesso ao número de formados em medicina na ESCS que haviam de fato sido admitidos para trabalhar na rede assistencial pública de saúde do Distrito Federal. A Escola se recusou a me passar os nomes completos dos formados alegando estas serem “informações particulares". Então, fui até a sede da Secretaria de Estado de Saúde do Distrito Federal (SES-DF) tentar ter acesso essas informações e lá me alegaram que também não poderiam passar estes dados por serem relacionados à questões de "saúde pública" e que a pesquisa teria de ser primeiro aprovada junto à um comitê de ética da própria SES-DF. Visto a densidade e quantidade de obstáculos que foram surgindo na obtenção dessas informações e com a consciência do reduzido espaço de tempo disponível para realizar a pesquisa a tempo. Considerando que uma das finalidades maiores da Escola é formar recursos humanos capacitados para trabalhar no sistema público de assistência de saúde e que ao mesmo tempo parecia não existir qualquer tipo de controle quanto ao destino dos seus egressos, na ausência desses dados eu vi a oportunidade de produzi-los.

Criei uma metodologia particular para construir esses dados. Na busca pelos nomes dos formados para poder contrastá-los com os nomes no banco de dados de médicos ativos no sistema público de saúde do Distrito Federal, cheguei às placas com os nomes dos formados que ficam penduradas na portaria da Escola Superior de Ciências da Saúde (ESCS). Essas placas são geralmente feitas pelas comissões de formatura das turmas dos cursos de medicina na medida com que cada turma se forma a cada ano e nelas ficam grafados os nomes dos formandos de cada turma. Tirei fotografias das placas das turmas formadas em cada ano e procurei nome por nome no banco de dados de servidores públicos do DF para checar a expressividade estatística dos egressos do curso de medicina da ESCS no mercado de trabalho público de medicina no sistema de saúde do Distrito Federal.

\footnotetext{
${ }^{9}$ Portal da Transparência do Governo do Distrito Federal: <www.transparencia.df.gov.br> Consultado em abril de 2014 .
} 
Um dos estudantes, o qual me ajudou na obtenção dos nomes dos estudantes que se formaram e aqueles que foram contratados pela Secretaria de Saúde do Distrito Federal (SESDF), alertou que a lista de nomes nas placas são "controversas" porque não traziam o nome de todos os formados, mas apenas daqueles que pagaram pelas cerimônias de formatura. Ciente disso, ainda confio no método escolhido porque a quantidade de nomes nas placas de cada turma coincidiram todas com o número de formados por turma que a Escola me informou, com exceção da turma IV, que teve, segundo os dados da coordenação, 84 estudantes formados e na placa havia apenas 80 nomes. Por mais que possa haver alguma margem de erro no cálculo das estatísticas apresentadas, é possível chegar a índices satisfatoriamente aproximados para os objetivos desta pesquisa.

O Gráfico 1 mostra a quantidade de egressos do curso de medicina da ESCS versus total destes que foram admitidos pela SES-DF. Cada turma formada está numerada de I à VIII anualmente no eixo horizontal. O eixo vertical relaciona a quantidade de egressos de cada turma com a quantidade destes que foram admitidos pela Secretaria de Estado de Saúde do Distrito Federal (SES-DF) desde que a ESCS foi criada até a primeira metade do ano de 2014. Idealmente, 640 médicos teriam se formado na escola se todas as 80 vagas tivessem sido preenchidas em todos os anos e se todos os estudantes tivessem se formado. O número total de médicos formados pela ESCS até meados de 2014 foi de 627, o que sugere que houve uma parcela dos estudantes que abandonou o curso por alguma razão ou que nem todas as vagas foram preenchidas; parcela de 15 estudantes, segundo os dados que a escola me passou.

A Escola Superior de Ciências da Saúde (ESCS) teve um total de 627 estudantes que se graduaram em medicina desde 2001, dos quais 263 foram admitidos para trabalhar na Secretaria de Estado da Saúde do Distrito Federal. (SES-DF). Isso corresponde à 41,94\% do total dos estudantes que se formaram na escola. Mais de um terço do total de estudantes que se formaram no curso de medicina da ESCS foram de fato admitidos pela SES-DF para trabalhar no sistema de saúde público do Distrito Federal. 


\section{Gráfico 1:}

Quantidade de egressos do curso de medicina da ESCS versus total destes que foram admitidos pela SES-DF por turma.

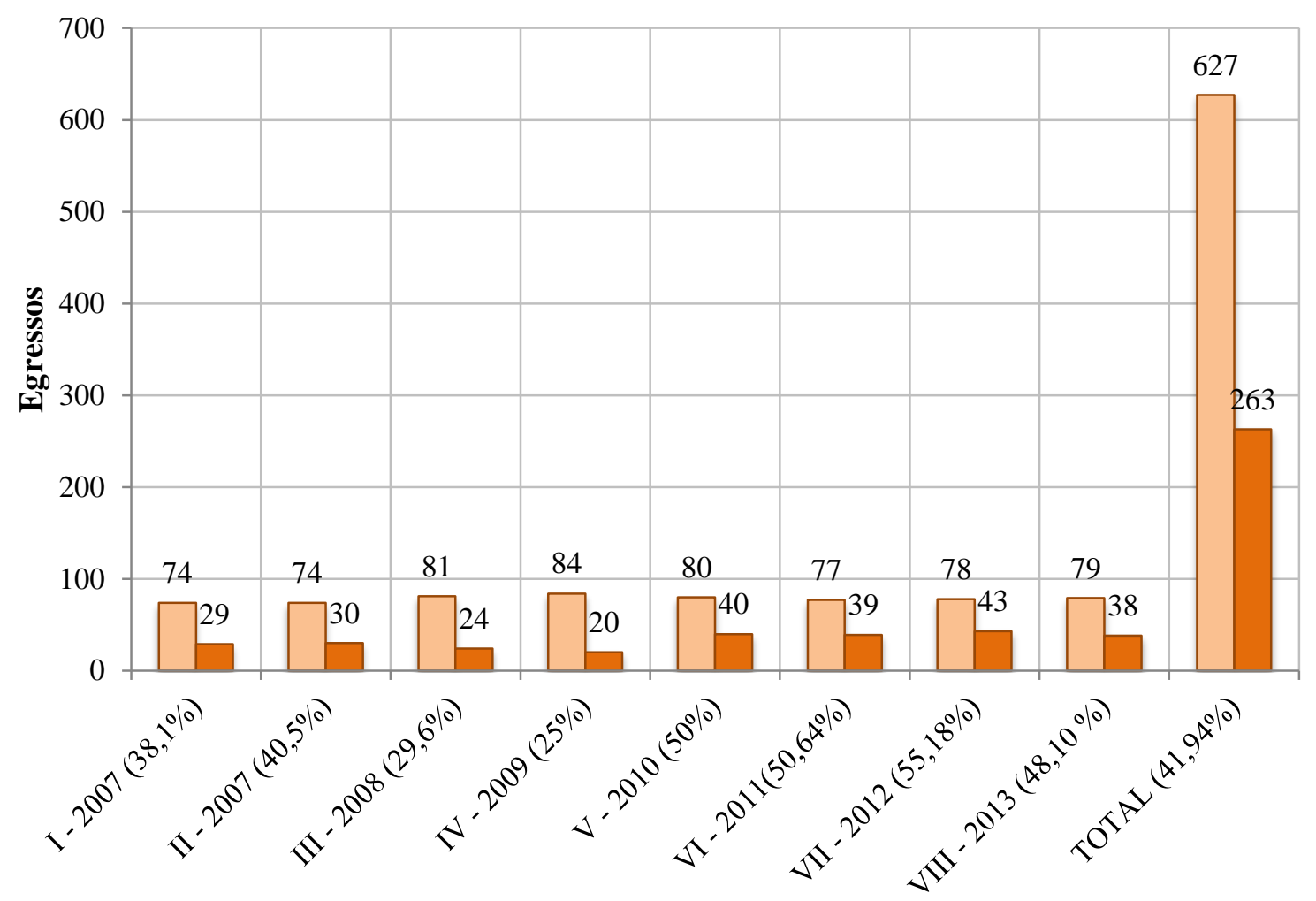

Turmas

$\square$ Quantidade de egressos da ESCS

$\square$ Quantidade de egressos admitidos pela SES-DF

Ampliei a busca e me perguntei qual seria a expressividade desses 263 médicos egressos da ESCS diante da totalidade do corpo médico da rede de saúde pública do DF. O Gráfico 2 mostra o total geral de médicos admitidos pela SES-DF por ano versus total destes que são egressos da ESCS, desde 2007 até a primeira metade de 2014.

Segundo dados gerais sobre o total de contratações de médicos que o Governo do Distrito Federal fez desde 1960, quando Brasília foi inaugurada, em toda a história do sistema público do DF até abril de 2014, foram um total de 7.270 admissões de médicos desde o princípio do sistema de saúde do Distrito Federal. Desse total de 7.270, que é o mais geral, 2.064 se aposentaram ou estão inativos até o momento. Decorre, então, que a Secretaria de 
Estado de Saúde do Distrito Federal (SES-DF) tem atualmente 5.206 médicos ativos. Analisando o Gráfico 2 e contrastando-o com esses dados quantitativos gerais, de um total de 2.714 médicos admitidos para trabalhar na SES-DF desde 2007, 263 são médicos formados pela ESCS. Isso corresponde à 9,69\% do total de contratações que a Secretaria de Saúde do Distrito Federal fez desde 2007.

\section{Gráfico 2:}

Total geral de médicos admitidos pela SES-DF por ano versus total destes que são egressos da ESCS, desde 2007.

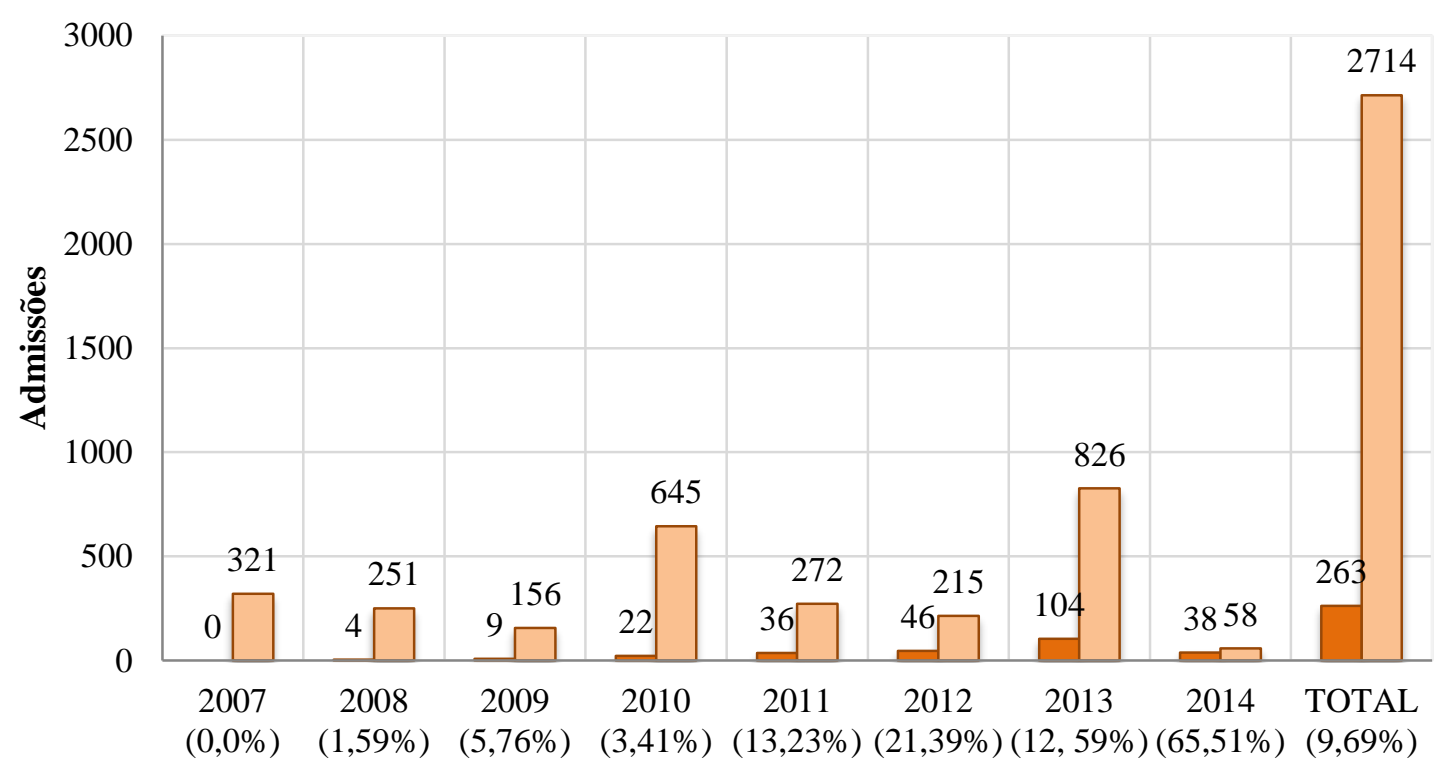

Ano

$\square$ Total de egressos da ESCS admitidos pela SES-DF

$\square$ Total geral de admissões de médicos pela SES-DF

Seja pela quantidade de estudantes inseridos no mercado de trabalho por ano a cada turma formada; seja pelo interesse que os estudantes egressos da ESCS tem em trabalhar no serviço público; seja pela natureza do processo pedagógico integrado aos serviços de assistência que talvez faça os estudantes seguirem carreira profissional no mercado de trabalho público; pelo o projeto da escola está atingindo seu objetivo em inserir seus egressos no sistema público de saúde local; ou o próprio mercado público para médicos tenha se tornado mais atraente, com 
o incremento dos salários e remunerações, que aumentou ao longo dos último anos, a expressividade de médicos egressos da ESCS na rede de saúde pública do Distrito Federal vem aumentando a cada ano. ${ }^{10}$

A fim de refinar ainda mais essas estatísticas, fiz a distribuição anual das admissões dos estudantes formados na ESCS desde que a primeira turma se formou. No Apêndice mostro a distribuição anual dos egressos que foram admitidos pela SES-DF por turma, e a tabela mostra que ainda existem egressos da ESCS que, por exemplo, se formaram em 2007 e ainda hoje estão sendo contratados.

Ressalto que apenas investiguei as contratações de médicos no âmbito do Distrito Federal e, considerando que muitos dos estudantes da ESCS vem de outras cidades do país, conforme foi possível saber durante a pesquisa de campo, provavelmente existem egressos da ESCS trabalhando nas Secretarias de Estado de Saúde de outros estados brasileiros ou mesmo em outros países, mas essa afirmação necessita de maior investigação para ser sustentada, ainda que soe bastante válida. Decorre que o argumento da "canibalização" não se sustenta.

Retomando a narração da assembleia de apresentação do Projeto UNISUS, um dos dois estudantes que anteriormente havia falado voltou a tomar a palavra e disse o seguinte:

\footnotetext{
O dinheiro do GDF que é destinado à escola deveria ficar nas mãos da gestão interna da escola, porque o governo nunca sabe das necessidades reais que a escola passa e quem sabe realmente das demandas são os estudantes e o corpo de gestão da própria escola. O governador veio apenas duas vezes à escola em seus quase quatro anos de mandato, e em todas as ocasiões por conta de solenidades e nunca de visitas técnicas ou estruturais. (Estudante de medicina. Fala registrada em diário de campo, $15 / 08 / 2013)$
}

Percebe-se que as críticas dos estudantes no contexto desse debate específico se direcionou às diretorias da FEPECS e da ESCS no que diz respeito à gestão da vida estudantil com vistas à estrutura e investimentos necessários a serem feitos e à baixa preocupação que o governo tem em relação à Escola na qualidade da relação diante da gestão do Projeto da ESCS

\footnotetext{
${ }^{10}$ Esses dados estatísticos foram construídos na primeira metade de 2014 e não foram computadas as admissões feitas através dos concursos públicos da Secretaria de Estado de Saúde do Distrito Federal depois da primeira metade desse ano, por isso os números na coluna 2014 no Gráfico 2 expressam quantidade menor de admissões, ainda que, proporcionalmente, o número de médicos egressos da ESCS seja significativo frente o total de admissões feitas pela SES-DF naquele ano.
} 
como um todo, incluindo o Projeto UNISUS. Diante da crítica disposta pelo estudante, um professor que estava presente na assembleia fez, em seguida, a seguinte fala:

\begin{abstract}
O modelo hospitalocêntrico de se fazer medicina no Brasil é histórico, centenário e fruto do sistema capitalista, e que, inevitavelmente, o ensino e a saúde estão amarrados juridicamente e que se houver uma transformação no sistema de ensino da FEPECS, esta transformação deve ser dada por completo, num processo que se encerre, e que não fique se arrastando de governo a governo. [...] A ESCS depende muito mais do $S U S$ do que o SUS depende da ESCS, porque a escola tem pouca infraestrutura própria porque usa a infraestrutura do sistema público de saúde. As provas das residências tanto nos hospitais particulares quanto públicos, não são mérito exclusivo da ESCS, mas do Medgrupo ${ }^{11}$, que deve ser desmascarado por trazer um currículo paralelo ao da ESCS acabando com os valores do Programa Saúde da Família (PSF) e com a pedagogia da escola. [...] O poder da instituição médica e da indústria farmacêutica e de equipamentos tecnológicos sobre os currículos dos cursos de medicina no Brasil é muito forte e muito estruturante dos cursos. O complexo medico-industrial é muito mais forte frente o projeto UNISUS conforme ele é previsto. Chamo a atenção dos estudantes para que tomem cuidado para não fazerem a UNISUS ser 'boi de piranha', por ser um projeto inédito que não se sabe se vai funcionar bem ou não. É preciso uma transformação em um processo de médio e longo prazo e não de um ano para o outro. (Professor da ESCS. Fala registrada em diário de campo, 15/08/2013. Grifos meus.)
\end{abstract}

Dizer que se deve tomar cuidado para não fazer a UNISUS ser "boi de piranha" foi atentar para a novidade do projeto pedagógico diante do contexto tradicional hospitalocentrico do Sistema Único de Saúde (SUS) e, mais importante, à incapacidade da gestão pública em lidar com projetos inovadores no que diz respeito à formação profissional na saúde. Devido à força dominante do modelo tradicional de formação médica, por mais que o Projeto UNISUS venha inovar através do fortalecimento do vínculo entre ensino e serviço e venha implementar uma metodologia de ensino voltada ao campo social e de atenção básica, um processo verdadeiramente profundo de transformação no ensino médico só poderá acontecer se houver mudanças a médio e longo prazos ao nível da gestão pública da saúde especificamente e na atividade política na gestão pública como um todo, e não de um ano para o outro, conforme o professor dispôs a crítica.

Dizer que "a ESCS depende mais do SUS do que o SUS depende da ESCS" foi apontar para a origem política e ideológica do projeto de criação da ESCS no campo amplo das políticas públicas de saúde implantadas desde o nascimento do sistema de saúde nacional, o SUS, no seio da democracia participativa que se construiu no Brasil a partir do final dos anos 1980. Por

\footnotetext{
${ }^{11} \mathrm{O}$ Medgrupo é uma empresa nacional privada que oferece diversos tipos de cursos para estudantes recém graduados em medicina que pretendem entrar nos programas de residências clínicas, especializações, assim como prestar provas para concursos públicos nas secretarias de saúde, dentre outras coisas.
} 
ser um projeto de educação em medicina "inovador" e "paradigmático" dentro de um sistema público gerido pelo Estado e que se identifica com os teores da "assistência básica" propugnados pelas políticas públicas de saúde e democratização dos processos públicos, a ESCS - e todo o valor ideológico daquilo que busca implementar, isto é, a formação do "médico total", sujeito profissional consciente da realidade sociocultural das pessoas e formado através de um processo pedagógico que segue o modelo da autonomia pedagógica e da "integração biopsico-social" na interface entre o mundo da educação e o mundo do trabalho - posta desafios profundos à engessada gestão pública da saúde e da educação tanto ao nível administrativo do Estado quanto ao nível da legitimidade política e social do Projeto UNISUS.

A profundidade do dilema arraigado na afirmação de que "na ESCS forma-se no SUS para o SUS" aparece no contraste entre a ideologia e a política implicadas no Projeto UNISUS. A proposta de integração entre ensino e serviço aciona instâncias políticas, ideológicas, jurídicas e administrativas e a ameaça de que a UNISUS seja "boi de piranha" significa que a imbricação entre o mundo da educação e o mundo do trabalho ainda não foi naturalizada com profundidade suficiente a ponto de dar movimento ao processo de transformação de uma instituição de ensino em saúde moralmente alinhada com as políticas públicas de formação e provimento de médicos para atuarem na atenção básica.

As amarras existentes entre ensino e serviço parecem se firmar, portanto, na positividade ideológica, política e social da metodologia de ensino da Aprendizagem Baseada em Problemas (ABP) com cunho social vinculado à atenção básica, mote das políticas públicas nacionais de saúde brasileira. Uma transformação na qual haja mudanças profundas nas instâncias políticas, pedagógicas, institucionais, administrativas, sociais e ideológicas do Estado só seria possível em médio e longo prazo. Caso contrário, a celeridade do processo de implantação da universidade a colocaria no campo da experimentação e "politicagem".

A arena de discussão na assembleia pôde ser definida da seguinte maneira: as diretorias da FEPECS e da ESCS estavam cumprindo os planos políticos e estratégicos do governo voltados para a educação em medicina no âmbito local, tal qual preconizava o Plano de Saúde do Distrito Federal para os anos 2012-2015. As eleições no ano seguinte foi fator importante para a acusação de que o Projeto UNISUS era "politiqueiro" e que estava fazendo parte de uma jogada política contingente que ia de encontro à necessidade e tendência de transformação do ensino médico em médio e longo prazos e de forma mais profunda. Mas a transformação 
dependia de um processo não apenas interinstitucional e administrativo e não estava apenas no nível do plano das políticas do governo. Sua implementação dependia da profundidade e da naturalização ainda não atingida plenamente entre as instâncias de gestão do ensino e serviço no que diz respeito à implantação de projetos de ensino médico apresentados como inovadores no contexto público local. Isso gerava desafios à gestão e administração do Estado, à implementação de um projeto pedagógico considerado inovador na prática e à naturalização moral ampliada da necessidade dessas transformações que "não se faz de um ano para o outro", mas em prazos maiores e áreas mais profundas da gestão política e moral dos projetos sociais e relações institucionais.

Pensando nas críticas à celeridade para a implantação da nova universidade, isto é, nas questões do tempo político, ou seja, no porquê o Projeto UNISUS veio à tona e tentou ser efetivado mesmo diante de intensas críticas quando à infraestrutura existente e em ano imediatamente anterior ao ano eleitoral de 2014, Palmeira (2002) diz que, além da ótica dos espaços, também é possível pensar a sociedade através dos tempos. Ele ajuda a perceber que o momento de discussão do projeto da nova universidade em face do processo eleitoral no ano seguinte era propício para que os caminhos políticos estivessem abertos para a execução do Projeto UNISUS naquele momento, mesmo já sendo pensado há vinte anos desde a época que o próprio Sistema Único de Saúde (SUS) foi criado.

\footnotetext{
É como se estivéssemos diante de uma refração da oposição eternidade-tempo, com o tempo cotidiano (o 'curso do tempo' dos dicionários) assumindo o lugar da 'eternidade', do permanente, e o tempo e posição do 'tempo', do contingente, do transitório. Mas, por paradoxal que pareça, nesse 'transitório' está embutida a ideia de excepcionalidade. Trata-se de criar um tempo próprio para o desempenho de atividades consideradas importantes para a sociedade. (Palmeira, 2002, 172-3)
}

Segundo Palmeira (2002) os projetos políticos ganham caráter de excepcionalidade nos tempos e espaços cotidianos da política apesar de o processo público surgir com base numa dada transitoriedade dependente das configurações políticas e contextos dos atores sociais no nível da condução desses mesmos processos políticos e institucionais numa determinada época sazonal da sociedade, como por exemplo, o tempo da sazonalidade eleitoral, época em que projetos políticos são definidos, ainda que situados, muitas vezes, apenas no campo das ideias. É preciso pensar os processos sociais e políticos não apenas levando em consideração os seus "tempos", mas também os "espaços" nos quais se desdobram as atividades políticas. A conjugação dessas duas variáveis foi um desafio para o processo institucional quando uma das 
reuniões do Conselho de Saúde do Distrito Federal (CSDF) foi deslocada de seu local usual para o espaço da própria Escola Superior de Ciências da Saúde (ESCS), procedimento que conjugou, em um mesmo tempo e espaço, formatos distintos de deliberação pública e diferentes mecanismos de representação social.

O evento narrado até aqui foi analisado para que o projeto da nova universidade fosse apresentado formalmente e publicamente aos diversos atores sociais envolvidos com o Projeto UNISUS. A função da apresentação do projeto internamente não tinha função deliberativa, cujas instâncias foram definidas no âmbito externo da Escola junto à outros atores políticos e sociais da administração pública do Distrito Federal, tais como o Conselho de Saúde do Distrito Federal (CSDF) e o Conselho Legislativo do Distrito Federal (CLDF), instâncias que figuram na descrição dos eventos seguintes.

\section{“OS CAMINHOS ESTÃO ABERTOS"}

Um mês e meio depois, no dia 01 de outubro de 2013, aconteceu uma consulta pública sobre a criação da Universidade de Ciências da Saúde do Distrito Federal (UNISUS) com um debate sobre o projeto de lei que cria a UNISUS. O projeto de lei trata da alteração da Lei 2.676 de 2001, lei que criou a Fundação de Ensino e Pesquisa em Ciências da Saúde (FEPECS). Qualquer cidadão comum poderia participar da consulta pública pela internet, enviando sugestões, e também do debate no auditório da própria FEPECS. No total havia cerca de 10 estudantes no auditório e alguns poucos professores e servidores da Escola Superior de Ciências da Saúde (ESCS). O auditório estava bem vazio, com 20 pessoas ao total aproximadamente. O debate aconteceu desde as seis horas da tarde até por volta das oito horas e meia da noite. Os parágrafos seguintes narram o evento.

Entraram no auditório algo como uma dezena de pessoas. Uma delas era presidente do Centro Acadêmico Mourad Ibrahim Belaciano (CAMIB), o centro acadêmico estudantil dos estudantes de medicina. Depois, adentrou no auditório um senhor, este, professor, que se voltou para os dois estudantes, que estavam sentados com meia dúzia de colegas, e começou a falar coisas que diziam respeito à aprendizagem dos alunos nos módulos curriculares da ESCS. A conversa entre eles era sobre a experiência do professor no modulo de Interação Ensino- 
Serviço-Comunidade (ESCS), na vila Basevi, na qual pude acompanhar uma das atividades que foi narrada no capítulo anterior. O professor relatava, com gestualidade excitada, o tanto que ele havia ficado impressionado com as atividades na vila e que tinha planos de "instrumentalizar a aprendizagem dos alunos" através do fornecimento e utilização de softwares e aplicativos para análise de dados, estatísticas, dentre outros "aparelhos que tornariam o trabalho dos estudantes mais interessantes para eles mesmos" e com um "teor de qualidade e sofisticação" maior. O professor estava com um tablet em mãos e, continuando com maneiras gestuais enérgicas e compenetradas, mostrava aos estudantes um aplicativo em seu aparelho que queria introduzir como ferramenta para pesquisa nos trabalhos da escola. Uma roda de conversa se formou entre alguns estudantes e esse professor.

Logo mais, a presidente executiva da FEPECS entrou no auditório, a mesma pessoa que havia apresentado o Projeto UNISUS na assembleia narrada anteriormente. Rapidamente, colocou papéis e pastas sobre a mesa do auditório, preparando o debate. Depois disso saiu rapidamente, ficou por uns dois minutos do lado de fora, talvez conversando com alguém, e logo depois entrou e se pôs a conversar com o pequeno grupo de estudantes e outros dois professores, inclusive aquele professor que antes falava excitadamente sobre os aplicativos eletrônicos para análise de dados. A pequena roda de conversa aumentou. Nela estava a diretora executiva da FEPECS, o presidente do Centro Acadêmico Mourad Ibrahim Belaciano (CAMIB) e outros cinco colegas, dois professores. Cada um envolvido na conversa se expressava através de uma gestualidade interativa que parecia ser muito mais política do que uma interação ordinária entre comuns. A diretora da FEPECS falava alto, como que fazendo campanha aos que estavam na roda de conversa, sobre projetos da escola que deveriam ser entregues à Câmara Legislativa do Distrito Federal (CLDF), que teriam a função de atuar como forma de "panfletagem", para usar suas próprias palavras, na Câmara Legislativa e para outros sujeitos das camadas altas do Governo do Distrito Federal (GDF). Falava de outros projetos e reuniões que estavam para acontecer nas semanas que se seguiriam e, enquanto falava dos projetos a serem entregues, levantava sua mão para que os outros estudantes batessem na sua, como cumprimento de comemoração. Significativo foi ver que enquanto batiam suas mãos em cumprimento caloroso, a diretora da FEPECS dizia "escsss!” a cada vez, em analogia a expressão “yesss”, na língua inglesa, parecendo querer contagiar as pessoas presentes. 
É inevitável pensar na noção de proselitismo nas atitudes politico-interativas nessas ocasiões porque, nesse caso, a diretora parecia ter uma atitude militante para com os presentes naquela pequena interação dentro do auditório. $\mathrm{O}$ ar panfletário e o teor político da movimentação e gestualidade dos corpos, das modulações vocais, e a dança dos olhares traziam toda uma atmosfera emblemática que expressava a situação política que estava acontecendo tanto num âmbito macro das relações da Escola Superior de Ciências da Saúde (ESCS) com o Governo do Distrito Federal (GDF), quanto a nível interno, micro, da relação da direção da escola com o presidente do Centro Acadêmico Mourad Ibrahim Belaciano (CAMIB) e com outros estudantes e professores que estavam presentes naquela pequena roda de conversa. Enquanto esse grupo de pessoas conversava, outras pessoas adentraram o auditório. Não havia sido dado início oficial ao evento ainda e todas as atenções estavam voltadas para a roda de conversas que agregava direção, discentes e docentes num mesmo círculo num momento propício e ao mesmo tempo informal para a expressão de suas posições acerca do projeto da nova universidade. Na medida em que a diretora da FEPECS mantinha seu discurso particular na pequena roda de conversa e assim como o presidente do CAMIB também falava e gesticulava enquanto expressava seu discurso, as outras pessoas dentro do auditório os olhavam com ar de curiosidade e empatia, como que fazendo elogios secretos ao engajamento e compromisso deles com o projeto institucional. A forma com que os olhares se direcionavam ao grupo no qual eles estavam neste momento indicou a natureza política daquela interação e a forma com que as relações internas dos atores institucionais em questão se mostrava imediatamente antes do início do debate.

O debate tinha como pauta a discussão e revisão da minuta do projeto de lei de criação da UNISUS, que fora divulgada no site eletrônico ${ }^{12}$ da instituição dias antes. Uma minuta é a primeira redação de um documento legal escrito e esta tratava da alteração da Lei 2.676 de 12 de janeiro de 2001, lei que criou a FEPECS, a qual, segundo o texto da minuta e dos documentos publicados sobre a nova universidade, continuaria na posição de mantenedora, agora da chamada Universidade de Ciências da Saúde do Distrito Federal (UNISUS). Ponto a ponto, a diretora da FEPECS foi lendo o documento, isto é, a minuta do projeto de lei que altera a lei que cria a FEPECS e foi pedindo sugestões de alteração, verificando a construção textual do

\footnotetext{
$12<$ http://www.fepecs.edu.br/index.php/noticias/436-consulta-publica-e-debate-sobre-o-projeto-da-lei-unisus > e $<$ http://www.dominioprovisorio.net.br/ArquivosDiversos/PLunisus25092013.pdf>
} 
projeto de lei. Ela começou falando, e disse isso em muitas outras ocasiões como esta, que "mudar uma lei é muito mais fácil, juridicamente falando, do que criar uma lei nova" e que por isso este projeto de lei busca alterar a lei de criação da FEPECS e não criar uma lei nova.

O primeiro ponto de discussão foi sobre o artigo primeiro em relação ao termo "fica criada" a FEPECS. As sugestões percorreram os termos "cria-se", "mantem-se", "permanece criada", "permanece mantida". Neste ponto não houve mudança na redação do texto. Em seguida, clarificando que a gestão da FEPECS, que se tornaria a mantenedora da UNISUS com gestão vinculada à da SES-DF, define-se que a UNISUS “é uma universidade constituída por unidades descentralizadas, especializada por campo na área da saúde, com integração curricular intercursos", dizia o paragrafo primeiro do artigo primeiro.

Neste ponto aconteceu um frisson. A direção da FEPECS, falando em nome do Projeto UNISUS, defendia uma “descentralização dos campi e dos campos do saber em nível local”, dando o exemplo de uma outra universidade criada em Curitiba em que "os currículos dos diferentes cursos são integrados e intercambiáveis", podendo os alunos personalizarem seus currículos através de módulos pedagógicos de outros cursos oferecidos pela instituição educacional. Essa descentralização, segundo a diretora, "atinge as pessoas e a sociedade muito mais facilmente" porque pressupõe, ela disse, "integração curricular intercursos" e "unidades acadêmicas descentralizadas", princípios estes que regem o SUS, por similitude e em conformidade com as políticas públicas para saúde. E completou dizendo que o processo de aprendizagem "“roda' na sede e 'roda' no serviço", o que faz os estudantes circularem pelos diversos campi e unirem seus currículos através da possibilidade de cursar disciplinas e módulos curriculares de outros cursos, tanto na sede da escola quanto nas unidades de saúde. A discussão se deu sobre o termo "unidades descentralizadas". Sugeriu-se "unidades acadêmicas descentralizadas", "unidades educacionais descentralizadas", "unidades institucionais descentralizadas", "unidades acadêmicas e educacionais descentralizadas" e todas as combinações possíveis. Contudo, o frisson sobre este ponto se deu sobre o conteúdo da proposição descentralizada. Um professor tomou a palavra e disse que queria fazer provocações à diretora tendo visto que, na visão dele, a proposta de descentralização das unidades "provocaria e provoca, de qualquer jeito, uma centralização local dos estudantes", porque estudantes do Plano Piloto estudam na unidade da Asa Norte e os estudantes da unidade de Samambaia moram perto desta mesma cidade. Essa tendência localizadora que mina o 
conceito de descentralização tende a ser "como cupins no projeto político pedagógico da escola e trariam complicações futuras, porque a ideia de integração curricular parece bonita no papel, mas na prática não acontece", concluiu o professor.

A diretora então tomou a palavra e revidou as provocações daquele professor com outras. Disse que a integração curricular era fundamental para o projeto da escola e que estava "tentando aproximar ao máximo a criação da UNISUS com base nesse principio de descentralização, pilar das políticas de saúde da FEPECS e da SES-DF, por semelhança e proximidade acadêmica e pedagógica". Disse ainda que, com diversos campi descentralizados, o estudante ficaria mais perto do serviço público e da realidade social da saúde no Distrito Federal, assim “os alunos ficariam muito mais perto do serviço de saúde”, concluiu.

Em seguida, uma estudante tomou a palavra logo depois da diretora e, com o mesmo argumento que o professor que se pronunciara antes, ela disse que "para haver descentralização das unidades numa lógica intercurricular tem que haver desvinculação local dos cursos", o que incentivaria de fato os estudantes a comporem os currículos em áreas distantes de suas residências. Mas a estudante disse em seguida que na realidade atual isso não acontece, sendo irônica ao acrescentar que "se nem nos estágios curriculares dos $5^{\circ}$ e $6^{\circ}$ anos existe integração, imagine no curso todo...”. Risadas tomaram conta do auditório por um breve momento.

Posicionamentos e opiniões diferentes se formaram sobre a questão da descentralização. Tanto professores quanto estudantes concordam com o fato de que campi separados implicavam numa suposta tendência concentradora local de estudantes que dificilmente se deslocariam de uma unidade da escola para outra para cumprirem seus currículos. A diretora da FEPECS, fiel ao projeto político e à ideologia de integração que movimenta o Projeto UNISUS, manteve a defesa do projeto como estava, isto é interdisciplinar e inter campi. Segundo ela, abrir mão da ideia de integração entre as unidades da Escola, seria abrir mão de aspectos característicos do Projeto como um todo, até mesmo moral e ideologicamente, o que segundo ela seria uma contradição. Do ponto de vista daqueles que vivem mais diretamente o cotidiano pedagógico, isto é, estudantes e professores, a integração curricular intercursos e inter campi era algo fora de cogitação pelo fato de ser apenas idealmente interessante, mas dificultosamente praticável na vida prática das atividades pedagógicas diárias. 
Os tons de voz aumentaram depois que a estudante ironizou a ideia de integração inter curricular. Diante da crítica, houve trocas de argumentos de forma áspera entre os estudantes e a diretora da FEPECS, que disse o seguinte:

Uma reforma curricular é uma reforma política e é isso que estamos fazendo. Se não
existe uma integração curricular de fato é porque existe um condicionamento cultural
que impede as pessoas de se aproximarem umas das outras. Se vocês [estudantes e
professores] querem mudanças neste sentido é bom que haja, antes de tudo, uma
mudança de atitude cultural das pessoas umas para com as outras. [...] A integração
curricular intercursos é um desafio a ser enfrentado no ano de 2014. (Diretora da
FEPECS. Fala registrada em diário de campo, 01/10/2013)

A crítica em torno da descentralização parecia ser muito mais de grau do que de tipo, isto é, era interessante do ponto de vista da diversificação do currículo e do curso em si, mas a questão que gerava mais discordâncias era o tamanho do deslocamento físico cotidiano necessário para tal. Retoricamente, o que estava em jogo na fala da diretora era a defesa do Projeto UNISUS conforme estava sendo feito por parte dos gestores, cuja diretora da FEPECS fazia parte e agia, de uma forma ou de outra, segundo as pressões das instâncias superiores do governo local. Ainda, a crítica frontal que a diretora fez aos estudantes no contexto do debate seguiu o viés da atitude cultural de relacionamento e disposição social entre as pessoas, jogando a responsabilidade da falta de integração nas mãos daqueles que vivem cotidianamente a realidade pedagógica da escola, deixando escapar pela tangente as queixas quanto à inadequação prática de um modelo de gestão curricular cujos cursos são localizados em cidades diferentes mas que se pretendem integrados, pondo dificuldades à implantação dessa proposição. Nesse ponto a diretora pareceu irredutível diante da crítica quanto à excessiva descentralização prevista e criticou os estudantes e professores presentes no debate pela falta de determinada "atitude cultural" compatível com o Projeto UNISUS, pedindo que o assunto fosse encerrado e que o debate prosseguisse, passando por cima das críticas dos estudantes e dos professores quanto à questão da descentralização dos currículos e dos campi. Depois de um silêncio tenso que seguiu a troca de críticas entre a diretora da FEPECS de um lado e os professores e estudantes de outro, a discussão não gerou alteração nenhuma nesse sentido e o debate continuou.

A diretora da FEPECS leu os artigos seguintes na minuta do projeto de lei que criava a UNISUS, os quais tratavam dos princípios da nova universidade, pontos pacíficos entre todos. Muitos desses princípios estão já dispostos no regimento interno da ESCS e no projeto pedagógico, com poucas nuances diferentes. A diretora passou para a leitura de outro artigo, 
que dizia respeito ao regime de colaboração entre a Fundação de Ensino e Pesquisa em Ciências da Saúde (FEPECS) e a Secretaria de Estado de Saúde do Distrito Federal (SES-DF) e a diretora disse que a função daquele artigo era "para que a SES-DF perceba a UNISUS e seus princípios", os quais estariam voltados para uma "gestão para resultados, num regime antipaternalista voltado para a racionalização da burocracia e do projeto pedagógico". Foi possível ver a ênfase dada à transformação do modo de operacionalização administrativa e burocrática em prol da adequação das relações institucionais perante o Projeto UNISUS, que buscaria fortalecer o vínculo entre ensino e serviço não apenas na manutenção de um novo modelo pedagógico, mas também no âmbito das instâncias do Estado que administrariam e fariam a gestão da universidade futuramente.

No artigo sobre o quadro de funcionários e servidores da futura universidade, um novo ponto de tensão surgiu. $\mathrm{O}$ artigo tratava de contratação de pessoal, concursos, carreiras e afins. Com a criação da UNISUS, conforme o projeto de lei propunha, poderá haver contratação de pessoal através de concurso para própria universidade e não através apenas da Secretaria de Estado de Saúde do Distrito Federal (SES-DF), como acontece atualmente na ESCS. Nesse ponto, surgiram dúvidas entre os poucos servidores presentes no auditório sobre se haveria vagas exclusivas para concursados da SES-DF, como uma espécie de cota, e perguntou-se como ficaria a contratação de docentes de outras áreas que não a da saúde tais como do pessoal do corpo administrativo da futura universidade ou professores de outras áreas, por exemplo. Em resposta aos servidores, a diretora da FEPECS disse o seguinte:

\footnotetext{
Haverá preferência por captação de pessoal e de servidores através da SES-DF e haverá, também, um processo seletivo interno da própria UNISUS para contratação de pessoal também. Por exemplo, prevendo a pretendida ampliação de vagas das atuais 80 para as almejadas 160 vagas, haverá duas possibilidades de entrada de novos profissionais para trabalharem na nova universidade e suprir essas demanda: uma pela SES-DF e outra pela própria UNISUS para que aumente-se o número de docentes para darem conta do aumento no número de vagas. Até a universidade ser criada, o pessoal vai ser contratado através da SES-DF, como acontece até hoje. Como a ESCS tem só 12 anos de existência, não existe a possibilidade ainda de carreira docente dentro da UNISUS. Então não existe tempo suficiente para a existência de professores titulares vinculados, mas no futuro isso será possível, [...]O perfil do docente é que ele seja da UNISUS e deve ter cinco anos de ESCS, tendo de 20 a 40 horas de dedicação ao SUS ou a SES-DF. [...] A UNISUS terá como instituição reguladora a SES-DF, que é o 'cordão umbilical' da universidade, que liga as esferas políticas do governo às políticas públicas voltadas para a educação em saúde [...] A UNISUS estará funcionando por completo a partir de outubro de 2016 a janeiro de 2017, tendo aí um espaço de 3 anos para que a universidade se estabeleça com toda a documentação necessária e para que se faça a transição da gestão e estrutura da ESCS, ETESB e EAPSUS para a UNISUS. Temos ainda que criar um estatuto, um regimento interno e outros documentos exigidos pela secretaria de educação, documentos
} 
exigidos para a existência legal da instituição. (Diretora da FEPECS. Fala registrada em diário de campo, 01/10/2013)

Houve inicialmente uma confusão entre os termos "dedicação exclusiva" e "dedicação integral" por parte dos poucos professores e servidores presentes, pois houve dúvida sobre como pessoas que já trabalham no âmbito da SES-DF se vinculariam à UNISUS sem a necessidade de um novo concurso. Nesse ponto a discussão foi muito confusa e pouco resolutiva, permanecendo a questão da mesma forma, sem alterações importantes. As pessoas continuaram em dúvida e as perguntas pareciam não receber as respostas que precisavam. Uma discussão sobre o termo "docente cedido pela SES", conforme a minuta mostrava, ficou confusa para os presentes. A diretora da FEPECS temia o termo "cedido" por este conotar um status desprivilegiado ao profissional, dizendo que o termo mais adequado seria o de "vinculado", em função de convenio entre as instituições, e não "cedido", que conotaria possivelmente status inferior. Essa foi uma das poucas alterações nesse ponto da minuta do projeto de lei que criava a UNISUS. O restante das questões, principalmente quanto à contratação de pessoal, permaneceu sem respostas naquele momento.

Esgotada a leitura da minuta, a diretora teve a última palavra e disse que o projeto de lei discutido ali seria redigido, corrigido e alterado conforme a discussão que recém havia sido feita e que até o dia 15 de outubro seria então encaminhado para a Câmara Legislativa do Distrito Federal (CLDF) para ser aprovado, passando antes pela plenária do Conselho de Saúde do Distrito Federal (CSDF), entidade representante do controle social em saúde, o qual votaria sobre cada ponto no texto do projeto de lei visando sua discussão nas arenas da democracia participativa inerentes à gestão da máquina pública, política e representativa no que diz respeito à saúde.

Finalizando o debate, a diretora da FEPECS disse acreditar que até o final do ano de 2013 o projeto seria aprovado porque "os caminhos estão abertos" no âmbito do governo do atual governador, mas na realidade dos trâmites estatais e burocráticos dos projetos públicos, o caminhos não estavam tão abertos assim, ou ainda, tomaram certos atalhos quando o Projeto UNISUS se deparou com dissensos que impediram a concretização do projeto na data estimada, como ver-se-á na narração do último evento que segue nas páginas seguintes.

Apesar de o evento se tratar de uma consulta pública com vistas à angariar sugestões para a alteração da minuta do projeto de lei que criava a UNISUS, pouco foi alterado na minuta. 
O objetivo da reunião era que os presentes fizessem sugestões quanto ao texto apresentado, mas mesmo diante de algumas propostas de alteração, alterações na minuta foram praticamente nulas. Isso mostrou certa intransitoriedade desse procedimento de escuta e o tolhimento da interferência dos sujeitos interessados na medida em que suas críticas foram rebatidas pela diretora. Ao mesmo tempo, a discussão detida em termos que, para a diretora eram muito importantes, soaram como pouco significativos para aqueles que estava presentes, o que pareceu tomar o tempo da reunião com questões prescindíveis, desviando a atenção dos interessados das questões que de fato lhes interessavam.

A diretora da FEPECS ainda relembrou o fato de que aconteceria uma solenidade de criação da universidade naquele mesmo auditório na qual o governador Agnelo estaria presente para assinar o projeto de lei em público, consolidando formalmente a concretização legal que daria início à abertura das portas da UNISUS. A diretora disse que o evento estava sendo marcado para o final de outubro ou início de novembro de 2013. Ao final da reunião a diretora da FEPECS disse ainda que naquele mês disponibilizaria as camisetas, bótons e adesivos com a marca da nova universidade, os quais trago na Foto 4. É possível ver que os valores trazidos no projeto da nova universidade se expressam também na visualidade da sua marca. Primeiro, o nome da futura universidade "Universidade de Ciências da Saúde do Distrito Federal" não corresponde à sua abreviação "UNISUS", que evoca diretamente o Sistema Único de Saúde (SUS). Chamo atenção para isso porque, mesmo do ponto de vista nativo, o nome "UNISUS", o qual foi escolhido internamente pelo Conselho Deliberativo da FEPECS, não foi visto com bons olhos por muitos professores e estudantes por lembrar, de forma imediata, a ideia de "Universidade do Sistema Único de Saúde". A crítica maior se dirigia à sigla "UNISUS", a qual passa a ideia de que a universidade será exclusiva para o SUS; quando segundo seus membros isso é uma verdade parcial. 


\section{Foto 4:}

Material de divulgação do Projeto UNISUS: camiseta, adesivo e bóton.

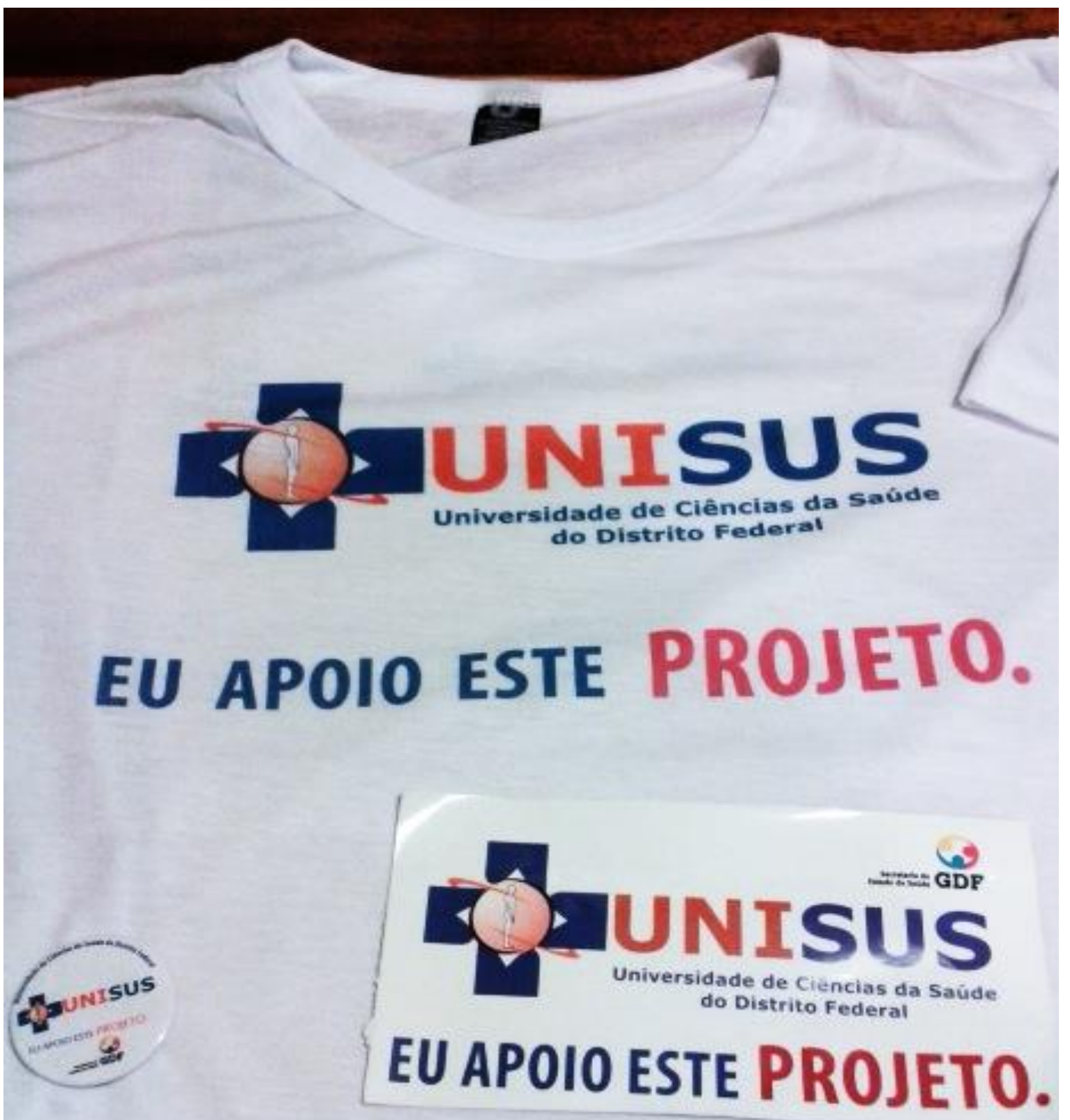


Olhando para a imagem da marca é possível ver o híbrido de três elementos dispostos no mesmo desenho. A marca da UNISUS é uma junção de três símbolos já existentes: o do Sistema Único de Saúde (SUS), representado pela cruz azul ao fundo; a marca da Escola Superior de Ciências da Saúde (ESCS), representada pelo círculo laranja ao centro com a figura humana envolta por dois traços circulares também laranjas; e ainda, de maneira mais sutil, a bandeira do Distrito Federal representada pelos quatro pequenos triângulos brancos. Além disso, a primeira versão do nome tinha as letras "UNI" grafadas em vermelho, cor que foi mudada para laranja, para trazer consigo a cor preponderante da ESCS, para manter a identidade da Escola na transformação.

Sobre essa reflexão visual, vale relembrar que o SUS é o filho pródigo da ideia de nação que foi implementada no Brasil desde o início dos anos 1990, emblemático da virada democrática e ampliação dos mecanismos de representação através do controle social na saúde, assim como na democratização da gestão da saúde pública. A presença da marca do SUS na marca da UNISUS traz a ideia de um complexo sistema nacional estruturado política e ideologicamente em prol da gestão da saúde no país e que faz parte de um projeto de nação que caracteriza as políticas públicas de saúde do Brasil. A junção da marca do SUS, a cruz azul, com a da ESCS, o círculo laranja, somado ao próprio nome da universidade, "UNISUS", passa a ideia de que essa universidade é uma instituição de ensino pertencente ao SUS, algo que, do ponto de vista nativo, é uma inverdade e desvia-se dos propósitos principais da instituição, fator que gera polêmica entre os membros da ESCS.

Nas palavras de um professor da ESCS, a nova universidade não deveria ser confundida como uma instituição exclusiva do SUS, e sim vista como uma instituição que forma profissionais para a sociedade brasileira como um todo. Ele disse o seguinte:

\footnotetext{
Como docente, tenho a apresentar uma questão que [...] é sobre a sigla que foi criada para nossa Universidade (UNISUS), que me soa estranho por não se tratar de uma Universidade do SUS ou 'exclusivamente' de formação para o SUS. Temos de formar médicos e enfermeiros ou tantos profissionais da área da saúde que forem possíveis, para a sociedade brasileira e não apenas para o sistema de saúde brasileiro. Nós somos uma instituição e não exclusividade do SUS. [...] É claro que queremos manter o sistema, mas não uma escola do sistema. Senão deixamos de ser uma Universidade no sentido laico e pleno. Estamos nos vinculando a apenas uma ideia ou, no mínimo, a uma ação de interesses. (Professor da ESCS. Comunicação via internet registrada em diário de campo, 15/10/2013)
}

E do ponto de vista de um estudante ele diz o seguinte: 
Não concordo com o nome 'UNISUS', mas também não concordo com a saída da ESCS do SUS ou da Secretaria de Saúde, pois nós somos fruto do SUS e é graças a ele que nossa metodologia tem dado certo até hoje. [...] Eu sei que a criação da UNISUS vem como uma jogada política do governo Agnelo para se reeleger, mas também não vejo problema em aproveitar o momento político para conseguirmos melhorar nossa Escola. (Estudante da ESCS. Comunicação via internet registrada em diário de campo, 16/10/2013)

Mais uma vez, vejamos a tensão que se estabelece entre a ideologia vinculada ao Projeto ao mesmo tempo que ela se torna objeto de manobra política. Vejamos o posicionamento dilemático que a Escola Superior de Ciências da Saúde (ESCS) tem diante de sua transformação em "UNISUS". Ela é uma instituição que nasceu de dentro das estruturas administrativas da Secretaria de Estado de Saúde do Distrito Federal (SES-DF), instituição gestora do SUS no Distrito Federal, mas ao mesmo tempo seu Projeto como um todo não se dirige somente ao SUS, mas à sociedade através da formação de profissionais da saúde a partir de uma metodologia pedagógica diferente dos modelos tradicionais de ensino e gestão pública. Apesar de ser uma instituição de ensino em medicina que surgiu nas instâncias administrativas e ideológicas do Sistema Único de Saúde (SUS) e com o diferencial de ter adotado uma metodologia de ensino e aprendizagem tida como inovadora, que é a da Aprendizagem Baseada em Problemas (ABP), os estudantes e professores da ESCS, ao mesmo tempo, relutam em serem reconhecidos como uma instituição exclusiva do SUS. Decorre dessa reflexão que a ideia de que "na ESCS forma-se no SUS para o SUS" é uma verdade apenas parcial porque é corrente entre os membros da ESCS a ideia de que, independente do nicho de trabalho que os egressos encontrem em suas carreiras profissionais, esses "médico totais" estarão, de qualquer maneira, contribuindo para a saúde da sociedade brasileira, estejam eles trabalhando no sistema privado ou público, no Brasil e até mesmo fora dele.

Considerando a breve reflexão sobre a qual fica a identidade visual da UNISUS, cabe destacar que o conflito mais tenso acontece em torno das questões administrativas e políticas da futura universidade. O principal ponto de tensão que envolveu o projeto de lei que criava a universidade se deu quanto à criação da função de reitor caso a universidade seja criada. Um reitor traria maior autonomia para a gestão institucional e GDF do ponto de vista dos membros da ESCS. Ademais, o processo de transformação institucional da ESCS em UNISUS envolve questões não apenas de ordem estrutural da hierarquia administrativa dessas instituições, mas vão também além disso, isto é, vão em direção à profundidade das mudanças ideológicas e políticas necessárias para que haja uma transformação do ensino médico na gestão da saúde 
brasileira que seja amplamente efetiva, profunda e duradoura. No entanto, a falta de entendimento e compartilhamento de interesses ideológicos e políticos entre os atores sociais envolvidos com a gestão pública da saúde e educação do Distrito Federal e a ineficiência dos processos democráticos e participativos na gestão pública da saúde na discussão em torno do Projeto UNISUS implicou em desgastes severos no processo de transformação institucional que se expressaram em desarranjos nos processos representativos da democracia e controle social inerentes ao processo de transformação institucional.

\section{“O QUE ESTÁ ACONTECENDO AQUI É DEMOCRACIA"}

"Vamos lá ver o que será" dizia a música citada pela diretora da FEPECS no final do debate para discussão do projeto de lei que criava a UNISUS, que seria futuramente cantada na solenidade em que o governador assinaria o projeto de lei, planejado para o ano de 2013, solenidade que não aconteceu. Perguntei-me, então, o que seria do Projeto UNISUS, e fui à reunião da plenária do Conselho de Saúde do Distrito Federal (CSDF), na qual os conselheiros de saúde votariam sobre os pontos do projeto de lei que foram debatidos no evento narrado anteriormente.

A reunião da plenária aconteceu no mesmo auditório no qual aconteceram os outros dois eventos narrados nas páginas anteriores deste capítulo e aconteceu no dia 15 de outubro de 2013. O objetivo era novamente "debater o projeto de lei que cria a FEPECS e a UNISUS" entre os representantes do Conselho de Saúde do Distrito Federal (CSDF) ${ }^{13}$, mas agora no

\footnotetext{
${ }^{13}$ Este tipo de concepção de gestão consiste basicamente na composição por usuários (50\%), gestores (25\%) e trabalhadores de saúde (25\%). O Conselho de Saúde do Distrito Federal (CSDF) é composto por representantes das seguintes instituições locais: na porção dos Gestores: Secretaria de Estado e Saúde do Distrito Federal; Fundação Hemocentro de Brasília; Hospital Universitário de Brasília; Fundação de Ensino e Pesquisa em Ciências da Saúde; Hospital da Criança. Na porção dos Trabalhadores: Sindicato dos Auxiliares de Técnico em Enfermagem; Associação Brasileira de Odontologia; Sindicato dos Enfermeiros; Sindicato dos Empregados em Estabelecimentos de Serviços de Saúde; Conselho Regional de Fonoaudiologia; Conselho Regional de Fisioterapia e Terapia Ocupacional; Associação dos Agentes Comunitários de Saúde; Conselho Regional de Nutrição; Conselho Regional de Farmácia; Associação Médica de Brasília; Sindicato dos Médicos; Sindicato de Odontologia. E na porção dos Usuários: Associação dos Inquilinos em Busca de um Teto em Samambaia; Associação dos Trabalhadores em Educação; Pastoral da Saúde da Arquidiocese de Brasília; Central Geral Trabalhadores do Brasil; Associação dos Aposentados e Pensionistas do DF e Entorno; Associação Cultural de Esportes e Artes Central; Federação de Mulheres do DF e Entorno; Sindicato dos Trabalhadores Rurais do DF; Associação dos Cidadãos Solidários ao Movimento Popular; Centro Scalabriniano de Estudos Migratórios; Grupo
} 
âmbito do controle social da saúde no Distrito Federal através da deliberação do Conselho de Saúde do Distrito Federal (CSDF) quanto ao projeto de lei.

A realização da plenária do Conselho de Saúde do Distrito Federal (CSDF) no auditório da própria Fundação de Ensino e Pesquisa em Ciências da Saúde (FEPECS), que ficava na sede da mesma, gerou o deslocamento de uma das reuniões do próprio CSDF, retirando-o da zona de conforto usual na qual sua reuniões acontecem normalmente e os trouxe para o território, isto é, a sede da própria FEPECS e ESCS. As reuniões desse Conselho aconteciam no Setor de Indústrias Gráficas, setor da cidade de Brasília afastado da ESCS onde se localizam alguns órgãos do governo local, como por exemplo, a Câmara Legislativa do Distrito Federal (CLDF). O fato de a plenária do CSDF ter acontecido na sede da Escola foi um ato de deslocamento na vida política dos atores sociais que manejam o projeto da universidade significou, em um certo sentido, a autopromoção e legitimação da FEPECS e da ESCS enquanto anfitriãs do Projeto UNISUS em um momento fulcral da trajetória do projeto de lei e seus desdobramentos políticos e ideológicos que marcava o caráter participativo e da gestão democrática da saúde pública no Distrito Federal.

O início da plenária estava marcado para as nove horas da manhã. Era por volta das nove quinze e a reunião não havia sido iniciada. Fiquei a observar a movimentação do lado de fora do auditório. Quando vi um homem adentrando o auditório pela porta lateral, entrei junto. Assim que entramos, ele, olhando para o auditório, com uma dúzia de pessoas sentadas, comentou, indagando um “Ué!?” em voz alta. E eu, perguntei: “O que é? Acha vazio?”. Ele olhou para mim e disse: “Sim, não está vendo?”, parecendo aborrecido. Segui para me sentar em alguma das cadeiras do auditório e esse homem seguiu para os fundos do auditório, onde estavam algumas pessoas. O auditório estava realmente vazio comparado às outras reuniões que acompanhei nos outros dias. Devia haver mais ou menos vinte pessoas, poucas sentadas nas cadeiras e outras de pé nas laterais do auditório mais algumas aos fundos. Falavam baixo.

Uma das secretárias da direção da FEPECS começou a passar por entre as cadeiras do auditório entregando papéis aos presentes. Ela os entregava a todos que estavam no auditório.

Arco-Íris; Grupo LGBTT; Associação de Mães em Movimento; Instituto Brasileiro de Estudo e Defesa das Relações de Consumo; Sindicato dos Trabalhadores Intérpretes, Guias-Intérpretes e Tradutores da Língua Brasileira de Sinais do Distrito Federal. 
Pedi a ela, quando chegou perto de mim, para que me entregasse também. Ela entregou dois documentos: Um trazia um texto chamado: "O porquê da Universidade de Ciências da Saúde no Distrito Federal?", texto de seis paginas trazendo uma justificativa da criação da UNISUS; e um outro documento, que era a minuta do projeto de lei a ser discutido nesta reunião.

Destaco, do texto de justificativa da UNISUS distribuído nesse dia, os seguintes trechos que, por mais que sejam longos, fazem compreender o sentido da transformação institucional no contexto de discussão do projeto da nova universidade segundo a argumentação disposta no discurso da própria instituição:

\begin{abstract}
A Lei nº 2.676, de janeiro de 2001, que dispõe sobre a criação da FEPECS, não reflete a concepção de gestão que deve orientar a relação entre as instituições mantenedora e a de ensino, a ESCS e a SES-DF. A necessidade de mudança torna-se premente diante dos avanços na compreensão e no conceito de gestão de ensino e de sua necessária integração com os serviços de saúde [...]. Diante disso surge a obrigatoriedade da adequação da lei vigente à realidade atual, em prol da qualidade e eficiência do ensino direcionado à formação de profissionais na área da saúde [...] o que também se constitui no grande desafio para a consolidação do sistema público de saúde do país.
\end{abstract}

$\mathrm{Na}$ área de pós-graduação a ESCS oferece 142 programas de Residência [...] Assomam-se ainda três cursos de especialização. [...] Em 2011 a Escola concluiu o Mestrado Interinstitucional com a Universidade de Botucatu. [...] Está em andamento, a segunda turma do Mestrado Multiprofissional [...]. Em julho deste ano [2013], [...] formou-se a $1^{\mathrm{a}}$ turma do mestrado Internacional [...]. Previsto ainda a $1^{\mathrm{a}}$ turma de doutorado [...]. Na área de pesquisa a ESCS está à frente de várias ações, como os Programas de Iniciação Científica [...]. O projeto docente-pesquisador é o mais recente desafio assumido pela Instituição ESCS.

Nesse contexto a Escola tem se apresentado como um espaço de construção de um futuro de plena cidadania para a população do DF por meio de processos formativos de aprimoramento do SUS-DF, ao aliar o processo educativo à inserção na rede de serviços [...]. Trata-se de um projeto educacional original, futurista e transformador da realidade e original porque surgiu como busca da própria SES de soluções para problemas crônicos e solidamente estruturados.

Esta proposta visa adequar o complexo educacional FEPECS, ESCS, ETESB, EAPSUS, transformando-o na Universidade de Ciências da Saúde do Distrito Federal - UNISUS, de modo a proporcionar o alinhamento da atual estrutura organizacional, propor diretrizes para a implementação da nova arquitetura organizacional e agregar a complexidade de dimensões e naturezas de recursos existentes. [...] A criação da UNISUS deverá: 1) potencializar a qualidade do ensino e da atenção à saúde [...];2) implementar ações educativas em saúde $[. .$.$] ; 3) favorecer o aprofundamento da$ integração entre os serviços e o ensino $[. .$.$] ; 4) promover o aumento de vagas [. ..] \mathrm{e}$ abrir espaço para outras formações [...]; 5) implementar a criação de um quadro profissional próprio da universidade [...]. (Diretoria Executiva da FEPECS, 2013, 15)

O texto revigorava os mesmos princípios políticos, pedagógicos e ideológicos que estavam por detrás do processo de criação da Escola Superior de Ciências da Saúde (ESCS) em 2001 - axiologicamente com a implementação de um currículo que integra ensino e serviço e 
adota metodologia pedagógica diferente da tradicional -, e a criação da UNISUS se situava como uma expressão do processo amplo de transformação do ensino médico e dos modelos de gestão da saúde que vieram surgindo no Brasil após a Constituição Federal de 1988, a democratização do país e a consolidação do Sistema Único de Saúde (SUS) nos anos 1990, emblema ideológico da política nacional brasileira de saúde nos últimos tempos.

No texto de justificativa também pode-se perceber que, no nível institucional, a justificativa incitava o aumento do número e diversificação das atividades que aconteceram na Escola ao longo de sua historia. Não apenas existiam os cursos de graduação em medicina e o de enfermagem, havia ainda a realização de pós-graduações, mestrados, e outros programas formativos que foram desenvolvidos ao longo dos 12 anos de existência da instituição. Tal alargamento na diversidade de atividades oferecidas conferiu força e competência suficientes para que a instituição fizesse parte dos planos de gestão do Governo do Distrito Federal (GDF) no que se refere às políticas públicas voltadas para a saúde e, sobretudo, para a educação e formação profissional em saúde no âmbito da gestão local.

As pessoas no auditório estavam, muitas delas, vestidas com a camiseta, cuja Foto 4 trouxe anteriormente. As camisetas estavam sendo distribuídas na porta principal do auditório para todos os estudantes e servidores da instituição. Observei pessoas saírem em grupos e indo naquela direção e logo depois as vi voltando com a camiseta. Julguei que seria importante para a pesquisa ter acesso à camiseta. Na entrada do auditório havia uma centena de pessoas conversando, dentre elas muitos rostos conhecidos. Estudantes, professores, servidores da ESCS e da FEPECS. A entrada do auditório estava abarrotada de gente. Circulei entre essas pessoas, busquei ter curtas conversas com algumas delas, das quais eu pude obter certos posicionamentos e informações pontuais quanto ao andamento do Projeto UNISUS na iminência da reunião, que serviram como dados instrumentais para guiar minhas reflexões quanto ao posicionamento dos atores institucionais diante do processo.

Já dentro do auditório, pude observar que a movimentação estava aumentando aos poucos. Aumentou o número de pessoas sentadas e formaram-se grupos que conversavam de pé nos corredores laterais do auditório. O som do murmúrio dentro do auditório foi aumentando gradativamente. A mesma moça que estava do lado de fora distribuindo as camisetas começou a passar fotografando as pessoas presentes dentro do auditório. Ela circulava por entre as cadeiras e pedia para as pessoas posarem para as fotos, todas tiradas em grupo, pelo que pude 
observar, para alguma eventual posteridade. As pessoas foram se sentando. Muitas olhavam recorrentemente para os fundos do auditório como que verificando quem e quantas pessoas estavam lá. Olhavam ansiosas, procurando e conferindo quem estava presente. Conversavam entre si e cochichavam umas com as outras ao pé do ouvido. Muita movimentação. As pessoas pareciam contar notícias umas as outras e eu pude visualizar uma certa coreografia do toque e das expressões faciais muito evidente. Expressões que conotavam a narração de estratégias de convencimento mútuo de questões que estavam acontecendo politicamente, pois esta reunião era considerada importante, pois haveria durante a mesma uma votação entre os conselheiros de saúde do Distrito Federal quanto ao projeto de lei da UNISUS. Aquele era um evento extraordinário no histórico de reuniões da Escola, uma vez que estavam presentes membros do Conselho de Saúde do Distrito Federal (CSDF), que deliberariam sobre o projeto de lei que criava a UNISUS; e deve-se considerar o fato que a reunião do CSDF foi deslocada de seu lugar usual de realização e estavam todos no auditório da própria FEPECS, que ficava na mesma sede a ESCS.

Eram dez horas no meu relógio e a reunião não havia se iniciado ainda; embora estivesse marcada para começar às nove horas da manhã. A movimentação no auditório já era muito maior do que no início. Por voltas das dez e meia eu calculei que o auditório estava metade cheio, com mais ou menos 100 pessoas, e com muitas pessoas ainda de pé na laterais e entre as cadeiras do auditório. Os estudantes pareciam se sentar juntos, perto uns dos outros, assim como fizeram no primeiro debate no qual o projeto da nova universidade fora apresentado e os estudantes fizeram uma série de reivindicações quanto à questões da vida estudantil na Escola Superior de Ciências da Saúde (ESCS). Enquanto isso, servidores, conselheiros de saúde, professores e outras pessoas se sentavam próximas umas das outras também, de acordo com o grupo ao qual pertenciam. Uma clara divisão dos grupos se fez espacialmente antes do inicio da reunião através da disposição das pessoas dentro do auditório. A posição física das pessoas dentro do auditório evidenciava a afinidade posicional deles diante uns dos outros no que se refere ao processo e debate sobre a transformação da instituição que praticamente todos ali faziam parte. A horda deliberativa, isto é, os conselheiros de saúde estavam sentados nas primeiras fileiras de cadeiras do auditório, de frente para a mesa onde estavam sentadas as diretoras das escolas e outros sujeitos dirigentes da ESCS e FEPECS no comando da discussão, sentados à mesa do auditório. No centro do auditório, atores centrais em todo o processo, pois o projeto da nova universidade dizia respeito diretamente à eles, os estudantes ocupavam maior 
espaço físico dentro da arena da reunião e a massa de estudantes que se formou bem ao centro do auditório nesse dia fazia pressão. Mostrando o quadro geral: os cargos dirigentes à frente, guiando o processo do projeto; ao centro, o corpo discente; e ao fundo estavam os servidores nas fileiras do fundo do auditório. As posições das pessoas dentro do auditório, nesse evento específico, marcaram os posicionamentos e opiniões dos atores institucionais diante do projeto e sua deliberação; em outras palavras, a fisicalidade disposta durante essa reunião ajudou a ver os diversos posicionamentos e afinidades em torno do Projeto UNISUS e do seu processo de condução nas esferas públicas da democracia participativa.

A diretora da FEPECS entrou no auditório por volta das dez e meia da manhã, com uma hora e meia de atraso, e ela era quem conduziria a reunião. Algumas pessoas resmungaram entre si por conta do atraso. A movimentação no auditório já estava alta e o falatório também. Havia música tocando em volume médio e dezenas de pessoas conversavam entre si por entre as cadeiras e pelos corredores do auditório. Entre a movimentação, um rapaz, que estava cuidando do posto de som e iluminação do auditório, colocou um microfone em um pedestal do lado direito do auditório, mais à frente, no corredor lateral, de frente para a mesa principal do auditório. As pessoas se dirigiram a esse microfone para falar durante a reunião. Momentos depois que as pessoas se sentaram, todos se silenciaram, a diretora da FEPECS empunhou um microfone e deu-se início à reunião. O auditório estava muito cheio, cerca de 300 pessoas, algumas de pé nos corredoras laterais e quase não se via cadeiras vazias.

Era 15 de outubro de 2013, dia do professor. Era uma reunião extraordinária do conselho deliberativo da FEPECS junto com os conselheiros de saúde do DF, era a "Plenária do Conselho de Saúde do Distrito Federal". A pauta era única: deliberação sobre projeto de lei que criava a UNISUS. A diretora da FEPECS, no inicio de sua fala, anunciou a pauta e falou sobre o modo como o debate aconteceria. Disse que iria ler os textos dos projetos de lei, versões deles, e que num momento seguinte, iria discutir ponto a ponto com os presentes. Fez uma ode ao dia do professor, elogiou os educadores da ESCS e os parabenizou pelo dia. O público bateu palmas nessa hora. Alguns estudantes bateram no ombro de professores que estavam sentados perto deles. A reunião parecia ter sido iniciada com clima promissor e amigável, que não durou por muito tempo.

A diretora da FEPECS enumerou quatro pontos específicos que guiavam todo o processo de criação da UNISUS: Primeiro disse que mudar uma lei na Câmara Legislativa era 
mais fácil, do ponto de vista da agilidade dos tramites burocráticos, do que criar uma nova lei; por isso o projeto de lei da UNISUS visava alterar a lei de criação da FEPECS, e não visava, portanto, a criação de uma nova lei; segundo, haveria de ser operada uma alteração na estrutura da FEPECS para ampliar seu sistema administrativo e adequá-la organizacionalmente às novas estruturas e hierarquias propostas; terceiro, haveria de ser discutida a regulamentação da função docente com criação prevista de um plano de carreira para os docentes, que não existia na Escola; e quarto, a FEPECS poderia firmar convênios com outras instituições tanto privadas como públicas e isso precisaria de investimentos e disposição política por parte de todos os envolvidos.

A diretora mencionou que entre 2007 e 2008 foram feitas as primeiras reuniões sobre a criação da nova universidade. Entre 2010 e 2012 houve uma intensificação no número dessas reuniões e no final de 2013 o projeto deveria estar pronto para ser enviado à Câmara Legislativa para ser aprovado. No entanto, o tempo desse planejamento não foi cumprido por conta dos conflitos e ineficiências na condução da reunião que narro agora, cujo colapso evidenciou as fragilidades das interações sociais, os limites da democracia participativa e a inabilidade na condução da discussão e deliberação sobre esse projeto de lei no âmbito administrativo do Distrito Federal.

Ao terminar a fala inicial, a diretora da FEPECS passou a palavra aos presentes para que se manifestassem antes que se desse início à deliberação em si do projeto de lei. Um membro ${ }^{14}$ do conselho de saúde se levantou e fez uma fala ao microfone. Ele fez um encaminhamento dizendo que existia, no projeto de lei e na própria Lei 2.676 de 2001, um grave "problema de descrição das competências de cada instituição". O conselheiro de saúde disse que a gestão do projeto de lei estava sendo feita com técnicas legislativas inadequadas visto que, era visada a alteração da lei de criação da FEPECS, haveria de ter uma outra lei que criasse a UNISUS, como que em dois projetos de lei separados, na opinião dele, ou seja, uma que alterasse a criação da FEPECS e outro que criasse a nova universidade. Porque, em sua visão, caso contrário, haveria artigos e descrições de competências institucionais "cá e lá", ou seja, tanto no texto de alteração da FEPECS quanto no texto de criação da UNISUS, o que acarretaria em textos repetidos e possibilidade de confusão legal e jurídica. Esse conselheiro de saúde então

\footnotetext{
${ }^{14}$ Durante a pesquisa de campo não pude saber qual o cargo representativo deste conselheiro de saúde.
} 
sugeriu que se fizessem dois projetos de lei em separado ou que juntassem o texto de criação da UNISUS com o da lei que cria a FEPECS.

A questão colocada pelo conselheiro era mais séria do que parecia. A FEPECS era presidida pelo secretário de saúde do Distrito Federal. Na futura UNISUS a atual diretoria da ESCS, da FEPECS e os estudantes querem a criação da função de reitor, interno à universidade, mais independente e autônomo em relação à gestão e à política da Secretaria de Saúde do Distrito Federal (SES-DF). Esse conselheiro quis dizer que, ou cria-se um novo projeto de lei que crie a UNISUS ou que altera-se o projeto de lei que cria a FEPECS de maneira mais profunda do que estava sento proposto.

Quando o conselheiro de saúde terminou sua fala, um servidor da FEPECS foi ao microfone logo em seguida:

\begin{abstract}
No modelo atual de gestão dessa instituição existe canibalização do SUS porque a FEPECS busca seus servidores e docentes através da SES-DF, retirando médicos da assistência e os colocando na função de docência. [...] Se o projeto de lei for discutido nas bases da SES-DF o interesse político por detrás desse projeto vai se tornar escancarado e as demandas internas dessa instituição vão continuar sem ser levadas em conta. [...] Então o debate tem que ser mais amplo do que está sendo porque o SUS deve ser fortalecido e a ESCS tem seu papel nisso, mas se a universidade for criada, ela [a ESCS] deve sim lutar para ter sua autonomia interna para a gestão das questões universitárias próprias. (Servidor da FEPECS. Fala registrada em diário de campo, $15 / 10 / 2013)$
\end{abstract}

A questão da "canibalização" da Secretaria de Estado de Saúde do Distrito Federal (SES-DF) pela Fundação de Ensino e Pesquisam em Ciências da Saúde (FEPECS) ser levantada por esse servidor mostra a candência da questão relacional entre a Escola e o SUS em torno do projeto da nova universidade. Se anteriormente a questão da "canibalização" foi colocada durante a apresentação do Projeto UNISUS, isto é, fora do nicho do controle social e em âmbito interno, nesse contexto, a questão foi colocada diante dos conselheiros de saúde, como, suponho, uma forma de fazer pressão sobre eles quanto às deliberações do controle social sobre o quadro de pessoal e esquema de contratação da futura instituição que, na visão de alguns, acarretaria um déficit de médicos na rede na forma como tem sido feitas as contratações de docentes para a Escola Superior de Ciências da Saúde (ESCS). No entanto, do ponto de vista dos estudantes e professores, sujeitos mais próximos dos processos pedagógicos e da vida estudantil em si, esse suposto desfalque de profissionais na rede era uma impressão errônea, pois a médio e longo prazos, a quantidade de médicos formados que a escola insere na rede de 
assistência do Distrito Federal supera o déficit de médicos na rede de assistência local, conforme também expus anteriormente com embasamento quantitativo.

A direção da FEPECS, que estava conduzindo a plenária, decidiu, então, fazer uma votação entre aqueles que eram a favor do projeto de lei como estava, isto é, com a descrição jurídica da FEPECS e da UNISUS no mesmo documento ou com dois projetos de lei em separado. Quem poderia votar eram apenas os conselheiros de saúde. Feita a votação através da contagem de braços erguidos, houve empate; entretanto, nesse momento, alguns conselheiros de saúde alegaram desconhecimento quanto às diferentes versões dos projetos de lei. Percebendo a desinformação, a diretora da FEPECS decidiu fazer a leitura dos dois projetos de lei para que, logo em seguida, primeiro, pudessem distinguir as diferenças e, segundo, fossem feitos destaques pelo público quanto à mudanças possíveis no texto do projeto de lei.

Na parte frontal do auditório estava um grande telão no qual estavam sendo projetados os textos das diferentes versões do projeto de lei que cria a nova universidade. Nesse momento estava projetado o documento que foi entregue no inicio da reunião para todos os presentes, com a minuta que altera o projeto de lei que cria a FEPECS vinculada à criação da UNISUS. Iniciada a leitura no telão em voz alta, a diretoria da FEPECS se deu conta que havia sido projetado o documento errado. O texto projetado no telão foi um com as alterações que foram feitas no dia primeiro de outubro, mas ainda não editadas, ou seja, foi projetado a minuta do projeto de lei com as edições inacabadas, ainda em processo de edição, com grifos coloridos e trechos repetidos. Foi um erro fatal que deu início à uma sequência infeliz de acontecimentos.

A diretora da FEPECS ficou visivelmente embaraçada, surpresa e ao mesmo tempo indignada com o erro diante do auditório lotado, ainda mais com os membros do Conselho de Saúde do Distrito Federal presentes. Pediu então que colocassem o arquivo certo a ser projetado no telão e pediu que tirassem novas cópias do documento correto e redistribuíssem-no imediatamente às pressas para não prejudicar mais ainda o andamento da reunião.

Analisando tal deslize com a ajuda da perspectiva de Goffman (1967) sobre a análise das micro interações sociais no que se refere aos constrangimentos públicos, pode-se dizer que, nessa altura da reunião, quando o erro quanto aos documentos distribuídos aos presentes foi percebido, a estabilidade do evento foi abalada e a interação entre os sujeitos presentes pareceu se voltar mais ao modo de condução da reunião do que ao conteúdo em si a ser discutido na 
reunião. Houve um desconforto geral e desconfiança por parte dos presentes em relação às diretorias da ESCS e FEPECS diante do erro naquele momento tão importante à deliberação do projeto da nova universidade. As pessoas começaram um falatório e, em determinados momentos, não conseguiam se escutar. Não tardou muito e logo se iniciou, coletivamente, uma confusão dentro do auditório.

Em meio ao alvoroço, um dos conselheiros de saúde se levantou, foi ao microfone e disse o seguinte:

\footnotetext{
O texto projetado no telão não é o mesmo texto que foi entregue ao conselho de saúde. Fomos todos pegos de surpresa num momento tão delicado como esse. [...] Essa pode ser uma tentativa proposital de nos confundir na leitura e na deliberação do projeto de lei que cria a UNISUS. Isso é um absurdo! (Conselheiro de saúde. Fala registrada em diário de campo, 15/10/2013)
}

Uma salva de palmas, assobios e gritos se ergueram forte por todo o auditório depois que esse conselheiro de saúde falou. Isso contribuiu ainda mais para que os ânimos dentro do auditório ficassem mais tensos e agitados. Mal havia começado o debate de forma plena e o auditório já estava num clima de impaciência e reclamação pelo atraso e pelo deslize cometido com a projeção da minuta errada. O erro gerou imediata desconfiança por parte dos conselheiros de saúde, que começaram a achar que a plenária estava sendo boicotada e que estratégias de enganação estavam sendo praticadas, primeiro, por conta do atraso de quase duas horas para que a reunião fosse iniciada e, segundo, porque o documento distribuído na reunião era diferente daquele que anteriormente fora enviado pela FEPECS ao Conselho de Saúde e era diferente do documento projetado no telão do auditório no momento da deliberação sobre o projeto de lei.

As secretárias da diretora da FEPECS distribuíram às pressas o documento correto em fotocópias entregues ainda quentes aos presentes. Nesse momento elas entregaram dois documentos: a minuta do projeto de lei que cria a FEPECS, na versão correta, isto é, com as alterações editadas; e outro documento com a minuta do documento que autoriza a criação da UNISUS, conforme foi exposta a possibilidade de que fosse feito um documento que mantém a FEPECS e outro que cria a UNISUS novo ou se apenas fosse alterada a lei já existente, isto é, a Lei 2.676 de 2001, que criava a FEPECS.

A diretora da FEPECS começou a fazer a leitura do documento, isto é, da minuta do projeto de lei que autorizava a criação da UNISUS. Na medida em que lia, pedia para que todos 
os presentes fizessem destaques sobre os pontos que gostariam de debater, para que, num segundo momento, cada um dos pontos fossem discutidos. A leitura durou cerca de 30 minutos. Em todos os artigos da minuta as pessoas fizeram destaques, sem exceção, de modo que em 13 artigos foram feitos 14 destaques, o que significava um índice alto de discordâncias quanto ao projeto de lei como estava proposto até aquele momento. Aconteceu que, em momento algum, a discussão dos destaques feitos aconteceu, porque a diretoria da FEPECS queria aproveitar a presença dos conselheiros de saúde para que a deliberação sobre o projeto de lei que alterava o funcionamento da FEPECS pudesse ser feita naquela mesma reunião.

Leu-se uma das minutas, uma que criava a UNISUS e depois deu-se início à leitura da minuta que visa a alteração da lei já existente. Novamente surgiu a discussão sobre se criavase um único projeto de lei no qual se estabeleceria a criação da UNISUS e a manutenção da FEPECS num mesmo documento ou se se fariam dois projetos de lei, um que mantinha a FEPECS e outro no qual se criasse a UNISUS. Em regime de votação, votou-se sobre a questão. Antes que a votação fosse iniciada, houve uma grande confusão. Muitas outras pessoas dentro do auditório queriam votar também, dadas tantas discordâncias sobre as questões e tamanha era a importância do ponto. Estudantes levantaram as mãos para votar. Servidores levantaram as mãos para votar. Os conselheiros também. Assim como as pessoas na mesa levantaram as mãos na hora da votação. Entretanto, apenas os votos dos conselheiros poderiam ser computados. Houve muita dificuldade na contagem dos braços levantados pela quantidade quase descontrolada de braços que se ergueram. Foi feita outra tentativa de votação que não deu certo. Uns gritaram que era melhor fazer a votação em papel. Um alarido alto tomou conta do auditório.

Por lei, conforme o regimento interno do Conselho de Saúde do Distrito Federal (CSDF), apenas os membros da plenária do conselho de saúde tem legitimidade necessária para “definir ações de integração com outros conselhos setoriais com o propósito de cooperação mútua e de estabelecimento de estratégias comuns para o fortalecimento do sistema de participação e controle social” (CSDF, 2001, 2), assim como "emitir pareceres quanto à criação de novos cursos de ensino superior na área de Saúde no DF, no que concerne à caracterização das necessidades sociais" (Ibid.). Os conselheiros, atuando como representantes da sociedade civil, são como intermediários entre a sociedade civil e os projetos públicos, o que é um dos princípios do controle social e da democracia participativa, mas acontece que o modo de 
condução da reunião e os papéis de cada ator social e institucional dentro do evento se tornaram tão confusos e mal definidos e as atribuições de cada ator estavam demasiado nebulosas para que a deliberação pudesse ser feita.

Em meio ao clima tenso, decidi ficar mais perto da mesa do auditório para ver mais de perto as expressões e dinâmicas das pessoas responsáveis pela deliberação, que era o ponto focal de atenção de todos os presentes dentro do auditório. Sentei-me quase que em meio aos conselheiros de saúde. O público presente começou a tentar impedir o andamento da reunião. Daquele ângulo eu pude ver claramente a divisão dos grupos dentro do auditório. Mais a frente, onde eu me sentei, estavam os conselheiros de saúde e gestores da FEPECS; com um vazio de umas duas fileiras, onde me sentei, estavam sentados os estudantes, uns sessenta ou setenta, todos juntos, aglomerados ao centro do auditório. E ao fundo alguns servidores e professores, dentre outras pessoas. Ainda, os estudantes estavam divididos entre si entre estudantes de medicina e estudantes da enfermagem, este últimos mais ao fundo do grande grupo de estudantes. Era nítida a divisão entre as pessoas dos diferentes grupos envolvidos com a discussão e a maneira com que cada indivíduo se engajava num movimento interativo coletivamente articulado de modo espontâneo, mas que atuava como potencial desarticulador de toda a reunião, dada a enviesada tentativa de votação confusa da deliberação.

Lido o primeiro texto, o qual trazia a minuta de criação da UNISUS, a diretoria da FEPECS passou, em seguida, num clima assumida e explicitamente tenso, para a leitura da minuta do projeto de lei que criava a UNISUS. Leu-se tranquilamente os artigos primeiro e segundo, com os quais os conselheiros de saúde concordaram pacificamente; até que chegou a hora do artigo terceiro ser lido, o qual foi o ponto mais polêmico de todos: "A FEPECS será presidida pelo reitor da UNISUS, nos termos de seu estatuto" (FEPECS, 2013, 1).

Quanto o artigo foi lido pela diretora da FEPECS, para que a votação sobre o mesmo fosse feita, um dos conselheiros de saúde foi rápido ao microfone e disse o seguinte:

Levando em consideração o projeto pedagógico da escola, que é um projeto inovador
que vincula o ensino com o serviço de saúde, nada mais lógico, do ponto de vista da
estrutura organizacional, que o secretário de saúde seja o presidente da UNISUS.
(Conselheiro de saúde. Fala registrada em diário de campo, 15/10/2013)

Uma vaia uníssona vinda dos estudantes tomou conta do auditório imediatamente após o conselheiro falar. Os estudantes todos gritaram, balançaram os braços indignados enquanto 
falavam e gesticulavam com veemência agressiva voltados para a mesa do auditório, onde estavam sentadas as diretoras da ESCS e FEPECS, mais outros sujeitos dirigentes, e nas primeiras fileiras do auditório, os conselheiros de saúde. A essa altura, as pessoas já não escutavam mais umas às outras e a confusão se generalizou por todo o auditório. Muitos começaram a falar com um volume alto de voz e todos ao mesmo tempo.

A diretora da FEPECS então empunhou um microfone e, com gestos nervosos e pouco comedidos, começou a falar:

\begin{abstract}
Se a UNISUS for presidida por um reitor isso vai trazer a autonomia necessária à universidade para tomar as decisões de forma interna, considerando que a UNISUS será uma instituição que se vincula diretamente à Secretaria de Saúde, mas que não precisaria estar necessariamente sob sua jurisdição. Não só eu, mas muitas outras pessoas da escola estão há mais de 12 anos engajados na historia da FEPECS e este está sendo um passo muito importante para a criação de um espaço político digno para a escola. [...] Tenho muito zelo e muito carinho pela FEPECS. Minha vida está aqui nesta instituição. [...] A UNISUS deve ganhar independência em relação ao poder público e a FEPECS vai continuar na posição de mantenedora, mas esse é um momento de consolidação e expansão política e institucional [...] (Diretora da FEPECS. Fala registrada em diário de campo, 15/10/2013)
\end{abstract}

Os estudantes aplaudiram bastante quando a diretora da FEPECS falou isso; fato bastante significativo que mostrou o alinhamentos dos interesses desses dois grupos em torno do projeto. Enquanto falava, a diretora excedeu os três minutos de fala que cada um tinha para falar, conforme o combinado no início da reunião. Ela parecia ter ainda mais o que dizer, mas foi veementemente impedida pelas outras pessoas, inclusive pelos estudantes, de continuar. Largando com ira o microfone sobre a mesa, mostrou seu descontentamento diante do fracasso da reunião naquele momento. Enquanto isso a reunião continuou a acontecer e as pessoas continuaram falando umas por cima das outras enquanto outras iam ao microfone explicitar seus pontos de vista.

Um secretário da FEPECS, que estava sentado à mesa da plenária, tomou a função de condutor da reunião, que antes estava nas mãos da diretora da FEPECS, que excedera seu tempo de fala e fora impedida de falar. Ele empunhou o microfone e chamou outra votação. Era para ser decidido quantos dos conselheiros de saúde presentes eram a favor de a futura universidade ser gerida por um reitor ou se o seria pelo secretário de saúde. Perguntou-se, primeiro, quem era a favor da criação da função de reitor. Novamente, muitas pessoas no auditório inteiro levantaram as mãos, principalmente os estudantes. Isso confundiu a contagem dos votos válidos, isto é, os votos dos conselheiros de saúde, porque a quantidade de pessoas que 
levantaram a mão havia sido muito grande. Em meio aos braços levantados, o homem que chamou a votação alertou, enfático, que "quem tem o poder de decisão são apenas os conselheiros; os estudantes não tem direito de voto nessa reunião.”, finalizando, rude. A partir desse momento, a confusão se generalizou de forma definitiva.

O tolhimento da expressão do corpo discente por parte de membros da própria FEPECS criou a tensão mais fatal de todo o evento. Um grupo grande de estudantes, a maioria do curso de enfermagem, se levantou e começou a sair do auditório, todos resmungando coletivamente, indignados pelo fato de que não iriam decidir nada na discussão do texto que criava a futura UNISUS. Foram embora cerca de trinta estudantes do curso de enfermagem, todos de uma vez, aplaudidos pelos estudantes de medicina, que permaneceram. Aqueles que saíam, gritavam: "Essa universidade diz respeito diretamente aos estudantes!" ou ainda, "Se a gente não pode opinar, não tem por quê a gente ficar!", diziam em voz alta, frustrados, enquanto viravam as costas e se dirigiam à saída do auditório.

Nesse meio tempo, em meio ao caos, alguns conselheiros de saúde se levantaram de suas cadeiras e também se dirigiram à porta do auditório, ameaçando ir embora. A retirada imediata de alguns conselheiros de saúde fez com que a reunião não tivesse mais quórum para que fosse possível qualquer votação ou deliberação. Em meio ao alvoroço, uma das conselheiras de saúde foi correndo ao microfone, fez sua fala e, em seguida, uma querela entre alguns conselheiros de saúde, estudantes e servidores se formou na qual uns respondiam aos outros à distância e em voz alta dentro do auditório. O fracasso da plenária estava prestes a ser anunciado. Os trechos abaixo trazem as trocas de acusações entre os atores sociais nesse momento:

\footnotetext{
Essa saída dos estudantes do auditório é estratégica! [...] (Conselheira de saúde. Fala registrada em diário de campo, 15/10/2013)

É porque não vão ser vocês que vão estudar na universidade! (Estudante de medicina. Fala registrada em diário de campo, 15/10/2013)

Mesmo se fosse com reitor, a UNISUS também poderia propor coisas a respeito da SES-DF, mas a universidade não precisa ser submissa ao GDF ou a SES para decidir sobre as decisões internas. Já está na hora de ser criada a universidade e a FEPECS tem que ter independência em relação ao poder público, mas não está fazendo uso correto da autonomia que já tem. Isso é incompetência! (Professor da ESCS. Fala registrada em diário de campo, 15/10/2013)
}

Em meio à troca de provocações, o gestor da FEPECS, que tomara para si a palavra e a condução do debate, chamou novamente votação sobre o mesmo ponto, pois alguns 
conselheiros voltaram para dentro do auditório, convencidos por outros a se manterem no auditório a fim de garantir o quórum da plenária e tentar deliberar sobre o projeto de lei novamente. A votação foi refeita. Contaram-se 8 votos para a criação do cargo de reitor e 7 votos para que o secretário de saúde regesse a futura universidade.

Percebamos o resultado apertado da votação. Isso revela que não existia concordância entre os conselheiros de saúde quanto ao projeto de lei ou gestão da futura instituição; e a condução desastrosa da reunião contribuiu para a falha de todo o processo representativo no contexto da participação social no processo institucional. Uma votação tão apertada em meio à tamanha confusão pareceu deslegitimar o Projeto UNISUS na esfera democrática de deliberação e discussão no âmbito do controle social.

No momento da contagem dos votos, e tendo visto o resultado apertado de 8 a 7 , um dos conselheiros de saúde foi correndo ao microfone e disse: "Esta votação está sendo golpeada! Não se pode fazer duas votações sobre o mesmo ponto." Num estado de quase completa ausência de ordem, quando ele disse isso, alguns conselheiros se levantaram novamente e foram embora, definitivamente, acabando com qualquer possibilidade de que a plenária continuasse e tivesse algum resultado final eficaz. Nesse momento a reunião foi suspensa pelo condutor do debate "porque os estudantes inviabilizaram o debate", ele disse. Em resposta, os estudantes se indignaram com a colocação, se levantaram e começaram a se retirar coletivamente fazendo gestos bruscos com confrontações verbais agressivas direcionadas para os conselheiros e para os membros institucionais que estavam na mesa.

Uma das conselheiras de saúde que ainda permanecia, um pouco mais calma que todos os outros, foi ao microfone e disse que era "natural acontecer esses atritos porque esse é um espaço de disputa e a FEPECS deve ser respeitada e o Projeto UNISUS deve ser respeitado igualmente", completou. Outra conselheira disse em seguida: "Essa plenária precisa ser remarcada porque não temos condições de continuar por conta dessa baderna." Diante da fala dessa conselheira, uma estudante gritou diretamente com ela dos fundos do auditório e disse: “Quem está fazendo baderna é você!”. Trocas severas de acusações e agressividades verbais continuaram indefinidamente.

Ainda que tenha sido considerada uma desordem com consequências desastrosas à tramitação do Projeto UNISUS, um servidor da secretaria de saúde que estava presente na 
reunião foi ao microfone em meio à troca quente de provocações e, quando estavam praticamente todos de pé dentro do auditório e muitas pessoas já haviam ido embora, ele disse em voz alta ao microfone: "O que está acontecendo aqui é democracia! Faço um elogio à presença dos estudantes porque esse é um assunto que diz respeito diretamente a eles." Ele foi aplaudido com força pelos poucos estudantes que ainda restavam e sua fala foi como o fechamento do debate, ou melhor, embate, colocando um desfecho à reunião com direito à mensagem moral, qualificando o processo participativo e representativo que envolveu o Projeto UNISUS naquelas circunstâncias.

Indagou-se sobre se a reunião seria marcada para o dia seguinte ou para algum outro dia naquela mesma semana. Muitos conselheiros de saúde disseram que isso não seria possível por causa da pouca antecedência da marcação da reunião e devido à outros compromissos que alguns tinham nos dias seguintes. No último instante, a reunião foi remarcada para uma semana a partir daquele dia, mas agora na própria sede do Conselho de Saúde do Distrito Federal (CSDF), isto é, num local no qual apenas os conselheiros de saúde estivariam presentes para que estudantes ou demais atores sociais não interferissem durante as decisões do Conselho de Saúde quanto ao Projeto UNISUS.

A remarcação e transferência da reunião foram fatos que trouxeram fim à plenária e fizeram com que todos os estudantes se retirassem juntos, indignados e reclamando mais ainda pelo fato de que a presença deles não havia sido bem vinda e que, segundo alguns dos próprios conselheiros de saúde disseram, havia atrapalhado o andamento da deliberação. Ao final, muitos se aglomeraram na parte da frente do auditório e falando eloquentemente em voz alta uns com os outros. A diretora da FEPECS estava com uma meia dúzia de pessoas ao seu redor todas falando com ela ao mesmo tempo e a diretora parecia perplexa com o resultado da reunião; os conselheiros de saúde, alguns furiosos, pegaram suas coisas foram embora, com pressa, abruptos; os estudantes, à essa altura não estavam mais presentes. A reunião foi encerrada por volta da uma e meia da tarde em meio a uma multidão de vozes que se sobrepunham num palavrório desordenado; e ainda assim, revelando o posicionamento dos atores institucionais envolvidos com o Projeto UNISUS.

As pressões e reivindicações dos estudantes, ao invés de se voltarem aos aspectos mais cotidianos da infra estrutura e vida pedagógica na ESCS, na nova universidade ou no projeto educacional como um todo, na ocasião da plenária se focaram no retrocesso da autonomia de 
gestão dos recursos e da autonomia burocrática, administrativa e política da instituição de ensino e seu Projeto. Em meio à desordem, aparentemente desprovida de sentido, os posicionamentos dos atores puderam ficar mais claros nesse momento definidor do processo de transformação institucional. Uma série sucessiva de gafes potencialmente fatais foram aos poucos contribuindo para a degeneração do processo do debate, que culminou no encerramento dramático da reunião.

Nos dias seguintes à plenária fiquei atento ao espaço virtual de discussão e às mobilizações institucionais que se seguiram, principalmente por parte dos estudantes, quanto à repercussão da reunião, que foi muito comentada por todos nas semanas seguintes. No mesmo dia em que a reunião aconteceu, horas mais tarde, um estudante do curso de medicina publicou na página do Centro Acadêmico Mourad Ibrahim Belaciano (CAMIB) na internet um chamado direcionado à todo o corpo discente da ESCS, dizendo o seguinte:

\footnotetext{
Se não fossem os protestos dos estudantes de enfermagem e medicina durante a reunião do CSDF a lei de criação seria mudada pelos conselheiros, colocando novamente o secretario de saúde como presidente da FEPECS. Isso acabaria com todo o projeto e seria o maior retrocesso que poderia acontecer. Afinal, o que mais queremos é autonomia! Se com poucos estudantes conseguimos impedir e desestabilizar esse 'golpe político', imaginem se lotarmos o CSDF na próxima reunião. (CAMIB, 2013)
}

Isso pode significar que a representação do Conselho de Saúde do Distrito Federal (CSDF) no contexto de discussão do projeto se voltou mais às questões políticas da relação institucional e organizacional que tem com o Governo do Distrito Federal (GDF) e com a Secretaria de Estado e Saúde do Distrito Federal (SES-DF) do que aos princípios do projeto em si da nova universidade. É de interesse do corpo discente da escola que o cargo de maior escalão na nova universidade seja ocupada por um docente no cargo de reitor. A acusação de que a reunião fora como um "golpe político" se complementa com a crítica que um outro estudante fez quanto aos Conselhos de Saúde como um todo, na qual a ineficiência do controle social seria fruto de um sistema perverso estruturado por um jogo de relações políticas promíscuas que compõem o cotidiano da democracia participativa no controle social na saúde.

É por isso que SUS está como está. As conferências são deliberativas, mas as diretrizes prioritárias não são operadas pelos conselhos. [...] O que acontece? Nada. Dias vem, dias vão, e os conselhos se mumificam entre teias de aranha e de papel. Tudo com a grana do SUS. Quanto? Não sei, diga você. Mas de graça não é, com certeza. E é esse sistema perverso que alimenta a relação promíscua entre FEPECS e ESCS, até porque vários da FEPECS são membros do conselho de saúde. Então 
porque eles mudariam? (Estudante de enfermagem. Fala registrada em diário de campo, 17/11/2013)

As características da arena política foi definida por esse estudante como um "sistema "perverso que alimenta uma relação promíscua" entre as instituições mais diretamente envolvidas com o Projeto UNISUS. Ele criticou a inoperância do Conselho de Saúde frente a execução das deliberações em torno dos projetos públicos e criticou a excessiva burocratização dos processos. Nessa perspectiva, do ponto de vista nativo, o controle social na saúde, por não cumprir com o papel representativo em nome de interesses políticos degenerados, estaria aquém do que o Projeto UNISUS representa ideologicamente para o projeto nacional de crescimento da saúde pública e dos projetos de inclusão social através da formação de médicos na atenção básica, sensíveis à realidade sócio-econômico-cultural dos pacientes e ao modo de operação do sistema público de saúde brasileiro tanto no que diz respeito ao projeto de formação médicoprofissional que que implementa quanto à relevância política do projeto para o desenvolvimento do SUS e do próprio Estado.

Foi marcada uma nova reunião do Conselho de Saúde do Distrito Federal (CSDF) para uma semana depois na sede do próprio Conselho a portas fechadas para que o mesmo projeto de lei fosse deliberado. Mas, no dia imediatamente anterior à nova reunião, a pauta sobre a discussão do projeto de lei que cria a UNISUS foi retirada da nova reunião. Os estudantes se organizaram para protestarem em frente à sede do Conselho de Saúde do Distrito Federal (CSDF), mas com o cancelamento da pauta sobre o projeto da universidade, nada aconteceu.

O silenciamento das discussões em torno do projeto de lei significava a retirada da discussão do projeto institucional das esferas controle social na saúde, assim, significa o silenciamento de um processo democrático. Acompanhando as atas de reunião do conselho deliberativo da FEPECS, reuniões sobre o Projeto UNISUS foram realizadas pelo conselho, mas se abstiveram de rediscutir o projeto de lei porque julgaram que se a criação da nova universidade já estava prevista nos planos de saúde do governo não haveria porque discutir o projeto de lei de qualquer maneira. Pelas discordâncias em torno do projeto de lei no âmbito do controle social, o espaço que nutre o confronto entre as opiniões - o processo de discussão, ou seja, um processo da democracia - teria sido obliterado em nome de interesses políticos e eleitorais, tendo visto a abstenção do Conselho de Saúde em deliberar sobre o projeto de lei e à tentativa dos gestores do Projeto UNISUS em acelerar a aprovação do projeto de lei nos âmbitos 
legislativos e quanto à sua efetivação factual; tudo isso num processo de gestão de um projeto institucional público que passava por cima dos pontos de discordância que foram evidenciados ao longo desse mesmo processo.

No final de 2013 o Projeto UNISUS foi enviado novamente pela diretoria da FEPECS para o Conselho de Saúde do Distrito Federal (CSDF) para que internamente fosse votado novamente. Entretanto, o próprio CSDF decidiu não discutir novamente o Projeto UNISUS, conforme destaco um trecho da ata de reunião da $97^{a}$ reunião ordinária do Conselho Deliberativo da FEPECS, que aconteceu no dia dez de dezembro de 2013. Segue o desfecho do andamento do projeto nas instâncias do controle social da saúde:

\begin{abstract}
O projeto de lei [de criação da UNISUS] também foi discutido pelo Conselho de Saúde do Distrito Federal, como pauta exclusiva, no dia 15.10.2013. Naquela oportunidade, foi apresentado cada artigo do projeto de lei de alteração da lei de criação da FEPECS e de criação da UNISUS. Assim, a apresentação da proposta de que a presidência da FEPECS seria exercida pelo reitor e não pelo secretário de saúde, gerou uma polêmica onde alguns conselheiros concordaram e outros consideraram que a presidência da FEPECS deveria ficar a cargo do secretário de saúde. Após discussão e votação, oito conselheiros foram favoráveis à proposta e sete que a presidência deve ficar a cargo do secretário de saúde. Embora tivesse sido concluída a votação, o clima de tensão se manteve e a mesa dirigente achou melhor suspender os trabalhos, ficando decidido que a data da próxima reunião seria marcada posteriormente. Essa reunião, todavia, não aconteceu e o projeto ficou sobrestado até o dia 03 de dezembro de 2013, quando o assunto foi novamente incluído na pauta da reunião do conselho de saúde do distrito federal. Após discussão, aquele conselho entendeu que, tendo em vista que em 2012 já havia aprovado a criação da UNISUS; não seria, portanto, necessário fazer novo debate e, por isso, o projeto de lei seria retornado para a gestão da SES-DF que posteriormente encaminharia para o executivo, sem necessidade de voltar ao conselho de saúde. A [diretoria da FEPECS] que esperava a aprovação do projeto de lei pela câmara legislativa do distrito federal até o próximo dia 15 de dezembro, data final de funcionamento do plenário daquela casa. Todavia, devido a esse período em que o projeto de lei ficou parado, acabou sendo adiado para o ano de 2014. (Ata da $97^{\mathrm{a}}$ reunião ordinária do Conselho Deliberativo da FEPECS, 10/12/2013, 1-2)
\end{abstract}

Esse trecho se refere ao mesmo evento narrado anteriormente, isto é, à plenária do Conselho de Saúde do Distrito Federal (CSDF), cujo encerramento se deu em meio à um caos de acusações e trocas de provocações, mas aqui descrito conforme a ata de uma das reuniões do Conselho Deliberativo da FEPECS. Depois do fracasso na deliberação do projeto de lei no dia 15 de outubro, o projeto de lei que cria a UNISUS foi enviado novamente para o CSDF para que o mesmo realizasse uma outra reunião com o mesmo objetivo de votar novamente sobre os mesmos pontos, mas desta vez a portas fechadas, longe dos estudantes e outros atores sociais envolvidos com o projeto da universidade. Entretanto, o próprio CSDF se recusou à fazer novamente uma mesma votação e decidiu se abster da rediscussão do projeto de lei, pedindo 
para que este fosse enviado diretamente para a Câmara Legislativa do Distrito Federal (CLDF), instância que enfim tinha aval para aprovar o projeto de lei.

Adiado para 2014, o projeto de lei ficou parado e permaneceu da mesma maneira até o momento. Professores e estudantes dizem que "esse ano [2013] não sai de jeito nenhum”, ainda porque "ano que vem vai ser ano de eleição" e parece, assim, que não haverá tempo político suficiente para dar andamento à concretização da nova universidade. A intenção do grupo de trabalho de criação da UNISUS era que o projeto de lei fosse enviado - o que não aconteceu à câmara legislativa até o final de 2013, para que a universidade fosse implementada por volta de 2015, 2016, ou além.

Analisando o evento narrado através da ótica das micro interações sociais, o clima crescentemente perturbado e tenso da reunião, que culminou no seu encerramento desastroso, foi como a quebra do enquadramento social esperado para aquela ocasião, para usar o vocabulário de Goffman (1974). Segundo a perspectiva desse autor, problemas de enquadramento social tem a seguinte definição:

\begin{abstract}
Vemos, portanto, que ações e acontecimentos, e não apenas palavras, podem cair numa armadilha e ser desconectados da realidade. [...] Sob certas condições, por exemplo, os atacantes e os defensores envolvem-se num tipo de ação muito semelhante e, nessas circunstâncias, será fácil um deles interpretar erroneamente as ações do outro e, forçosamente, continuar a fazê-lo, já que a cada confrontação a tarefa de defesa dará a impressão de ataque. [...] De fato, dois defensores podem interpretar equivocadamente cada um a ação do outro e encontrar-se com um homólogo banal. [...] Os gritos, os sinais de alarme, sendo meios especializados para avisar do perigo, asseguram que tudo está bem quando não são acionados e assim introduzem, é claro, problemas específicos de enquadramento. (Goffman, 1974, 588)
\end{abstract}

Havia um objeto em comum que estava sendo discutido e seus pontos específicos deliberados por atores sociais investidos de autoridade representativa, figurados pela presença dos conselheiros de saúde do Distrito Federal dentro do auditório. A falta de articulação prévia interna ao Conselho de Saúde do Distrito Federal (CSDF) quanto à criação da função de reitor para a futura universidade se expressou no resultado apertado de 8 à 7 na votação sobre esse ponto, e também no modo desalinhado com o qual o processo político estava sendo conduzido dentro do evento democrático previsto e regulado pelas instâncias estatais, no ambiente de deliberação criado pela própria Fundação de Ensino e Pesquisa em Ciências da Saúde (FEPECS), lançaram muitas desconfianças quanto ao propósito, eficácia e validade das decisões que ali estavam prestes a ser tomadas. Praticamente todos os atores sociais presentes 
pareceram desconfiados do modo com o qual a reunião foi conduzida e uma aura insalubre se instaurou num momento tão significativo para a gestão democrática e participativa de um projeto educacional e de saúde vislumbrado no Projeto UNISUS e até no projeto já existente da própria ESCS.

A demora de quase duas horas para que a reunião se iniciasse; o texto errado projetado no telão, que gerou desconfiança por parte dos conselheiros em relação à veracidade dos documentos sobre os quais se deliberaria a construção da nova universidade; a votação apertada em torno da questão da criação da função de reitor em meio à um caos interativo que não permitiu a visualização transparente da decisão gerou desconfiança por parte de todos e pareceu degenerar o processo democrático em nome de interesses discordantes por parte dos grupos de atores sociais envolvidos com o Projeto UNISUS; e isso também somado ao fato de que os estudantes, atores sociais conscientes de que a gestão política da instituição de formação da qual fazem parte estava em jogo, também suspeitaram das decisões tomadas pelo controle social durante a reunião e reagiram de maneira brusca. Os atores sociais e institucionais presentes começaram a acusar uns aos outros de acordo com seus interesses. Os estudantes acusaram os conselheiros de enviesar o projeto da universidade conforme finalidades políticas e eleitorais; os conselheiros acusavam a diretora da FEPECS de estar burlando o processo de votação e discussão do projeto; os professores acusavam os estudantes e a diretoria de estarem não reconhecendo a fragilidade e novidade do projeto educacional almejado; mais uma série de outras acusações já dispostas anteriormente. Aqueles que recebiam as acusações se defendiam, retrucando as acusações com outras.

Conforme Goffman (1974) ajuda a refletir, diante de tamanha conturbação no enquadramento esperado para a reunião, facilmente as pessoas presentes pareciam interpretar equivocadamente umas às outras e à cada nova acusação, um novo grito aparecia e uma nova vaia soava. As explicitações de posicionamento esquentadas em meio ao caos que tomou conta da plenária mostraram problemas específicos de enquadramento situacional e o quão o Projeto UNISUS era minado por valores divergentes que cada ator dentro do processo tinha em nome das instituições que cada um fazia parte. Ao falar de enquadramento situacional, isto é, do "roteiro" que esperava-se para o encontro social coletivo face a face, o objetivo era que a reunião fosse bem sucedida e que sua ordem fosse mantida para que a deliberação pudesse acontecer de maneira eficaz e o Projeto UNISUS seguisse pelos meandros burocráticos do 
Estado. Mas o processo de transformação institucional foi minado por ações divergentes que se refletiram de maneira candente em cada desvio de enquadramento que a reunião sofria.

\begin{abstract}
Descobrimos, portanto, rupturas de enquadramento que partem debaixo, mas deixam os superiores - normalmente, os atores - no comando, podendo até funcionar, em última análise, para assegurar isso. Mas, é claro, pode estar envolvido algo mais ambicioso, a saber, confundir e desacreditar um adversário violando as regras do enquadramento da interação que ele está ajudando a manter. Estas ações não nos falam do papel organizacional das rupturas de enquadramento, mas sim das vulnerabilidades da experiência enquadrada. [...] É um problema situacional [...] Procura-se perturbar a tranquilidade e a ordem em ocasiões sociais, [...] para além da situação em que ocorre o ataque. [...] Ao pensar sobre a sabotagem social, torna-se claro que o que importa não é o simples volume de comoção e furor, mas o que conta é, mais uma vez, a relevância do enquadramento. Assim, a mera presença de certos tipos de testemunhas pode ter um efeito deflacionário grave. [...] Das várias formas de sabotagem social, a que mais nos interessa aqui é aquilo que às vezes é chamado de 'confrontação': um claro ataque frontal às regras básicas de uma ocasião social - o enquadramento de uma ação oficial - seguido de uma decidida recusa a aceitar a autoridade dos que consequentemente tentam restaurar a ordem. (Goffman, 1974, 518-22)
\end{abstract}

Na visão desse autor, a natureza das interações face a face é sempre vulnerável e incerta. Há uma fragilidade inescapável à toda e qualquer relação face a face que coloca a interação em risco constante de ser desestruturada e sair da linha de ação planejada, isto é, do enquadramento social esperado para a ocasião. Quando uma interação social sai de seu enquadramento devido a um desvio inesperado causado por algum acontecimento situacional, acontece a ruptura do enquadramento projetado para acontecer naquela ocasião interativa. Havendo a quebra do enquadramento esperado, os diferentes atores sociais passam a direcionar suas ações em sentidos muitas vezes opostos, desviando o foco da interação para níveis que vão desde confrontações mais imediatas quanto à condução do processo interativo até insinuações direcionadas às possíveis consequências da falência da interação social no nível da discussão do objeto comum em questão. Indo em direções opostas, os atores sociais envolvidos ficam sem parâmetros comuns para a continuarem com o foco da interação, que pode se desviar e gerar desestabilidade e cair em desordem. Restabelecer o foco da interação depois que ela sofreu desvios passa a ser desafiador para todos os sujeitos envolvidos.

Relacionando o evento narrado aqui, no qual o Conselho de Saúde do Distrito Federal (CSDF) estava presente, ao momento de criação da Escola Superior de Ciências da Saúde (ESCS) em 2001, no qual o projeto de criação da Escola não passou por tal Conselho, é interessante comparar os dois momentos para destacar a falta de entendimento e consenso que os conselheiros de saúde tem em torno do próprio projeto institucional e ideológico que vem 
sendo implementado pela Escola Superior de Ciências da Saúde (ESCS) em si, esta que veio liderando o Projeto UNISUS. A votação apertada, o desconhecimento do Conselho de Saúde do Distrito Federal (CSDF) sobre o projeto de lei da nova universidade e a condução desordenada da reunião foram indicadores do desentendimento interno entre os membros do próprio CSDF como um todo quanto ao Projeto UNISUS. Quero apontar para o fato de que o projeto de criação da ESCS não ter passado pelo Conselho de Saúde do Distrito Federal (CSDF), na época de sua criação diante do fato de que agora, no processo de transformação institucional desta instituição, o projeto da UNISUS ter de receber o aval do Conselho de Saúde do Distrito Federal (CSDF), que não chegou à um consenso sobre o projeto, talvez devido ao pouco desenvolvimento dos mecanismos cotidianos da democracia participativa não estarem desenvolvidos o suficiente na época da criação da ESCS, procedimento que veio sendo desenvolvido, com maior intensidade, a partir do ano 1990. (CNS, 2006)

Diante de tamanha confusão e má condução do processo de discussão e deliberação durante a reunião, o confronto e as críticas quanto à logística desajeitada e a ameaça iminente de ela ser interrompida a qualquer momento pode ser considerada como uma forma de quebra do enquadramento. Na medida em que cada ator social acusava um ao outro de má condução do processo político ou quanto ao conteúdo do que estava sendo deliberado, a sabotagem, que também pode ser interpretada como desvio, era uma saída possível para que decisões indesejáveis não fossem tomadas, principalmente do ponto de vista discente, atores sociais mais diretamente envolvidos com as questões que ali seriam deliberadas.

Em se tratando das decisões políticas colocadas em ação durante a reunião, os "perturbadores da ordem" atuavam no interesse de uma coletividade momentaneamente perturbada que eles mesmos representavam coletivamente. O enquadramento esperado no momento da plenária tendia a ser iminentemente reordenado a cada momento, beirando a descontinuidade do debate na medida que cada ator social emitia um gesto ou uma fala. A ideia de sabotagem possibilita colocar em evidência as rupturas no enquadramento social interacional que tinha o potencial de desorganização no espectro de toda a atividade com consequências desastrosas ao andamento da reunião em si e do Projeto UNISUS.

Ainda que o valor atribuído ao Projeto UNISUS enquanto o "futuro da ESCS" e expressão do crescimento de um projeto integrador da gestão da educação e da saúde, inovador da pedagogia do ensino da medicina, significativo política, ideológica e moralmente, deve-se 
perceber que eram duas as instâncias principais nas quais o processo descrito se apoiou. De um lado havia a emergência de uma reorganização institucional interna que visava remanejar as estruturas administrativas e competências e de outro lado havia a carga ideológica trazida pela metodologia pedagógica inovadora voltada às políticas da atenção básica que a ESCS implementa, que projetava-se na UNISUS e, acima de tudo, implicou-se nos modelos políticos de gestão do próprio Sistema Único de Saúde (SUS). 


\section{CONSIDERAÇÕES FINAIS}

Tendo em mente que o Sistema Único de Saúde (SUS) foi fruto de um processo histórico do Estado brasileiro em busca da consolidação de um projeto de nação que buscava valorizar a moral cidadã através da saúde pública e pelos valores da democracia, e lembrando que a Escola Superior de Ciências da Saúde (ESCS) foi projetada desde os anos 1980, ou seja, num momento crucial para a configuração do quadro geral da política democrática de saúde no Brasil, quando a Constituição de 1988 foi promulgada e o processo de transformação política e ideológica aconteceu com a virada democrática, é preciso pensar nos limites da democracia participativa quando projetos públicos, como o da UNISUS, foi pensado, executado e ganhou significado social, político e moral a partir de sua criação e tramitação, levando em consideração o processo narrado ao longo desta capítulo.

Com a virada democrática no final dos anos 1980, a participação da sociedade foi tomada como princípio para a implantação de políticas públicas de saúde. Isso consolidou a construção de um país administrativamente mais democrático e politicamente maduro para gerir projetos de transformação institucional e garantir direitos à sociedade civil em participar dos processos públicos. Segundo Fleischer, Tornquist e Medeiros (2010), a reforma sanitária brasileira e a consolidação do Sistema Único de Saúde (SUS) passaram a garantir os direitos da população à saúde assim como o controle social passou a ter papel primordial na reforma dos serviços públicos de saúde. "Controle social” é um mecanismo da democracia participativa através do qual a sociedade civil, através de representantes de coletividades civis diversas, participam do planejamento, operacionalização, fiscalização e execução das políticas públicas e faz parte do projeto maior de nação brasileira cuja democracia participativa se fez pungente desde o início do século atual. Entretanto, por mais que esse seja um mecanismo democrático de participação social, existem limites inerentes ao seu funcionamento e eficácia quando os atores institucionais e sociais se encontram face a face uns aos outros para debater um objeto social em jogo na arena política de discussão e disputa. O dilema em torno desse mecanismo de participação democrática reside no fato de que, mesmo sendo democrático, ele não é direto e não é partidário, tornando representatividade da sociedade civil negociável a cada contexto específico. 
O Estado, entidade ideológica agregadora de valores, apesar de se encontrar acima da sociedade civil, é constituído por representantes dessa mesma sociedade civil. Mas não enquanto indivíduos ou movimentos sociais autônomos, e sim enquanto representantes de entidades organizadas em instituições que administram de forma indireta a vida política das instituições estatais segundo configurações morais e ideológicas específicas que os representantes da sociedade civil têm no contexto do controle social na saúde, por exemplo. A configuração de valores expressa nos encontros sociais nas arenas políticas de discussão de projetos público no contexto do controle social tende, assim, a variar a cada contexto específico a depender da posição que cada ator social ocupa no quadro das representatividades democráticas e políticas.

Analisando a plenária do Conselho de Saúde do Distrito Federal (CSDF) descrita neste capítulo, o fato de terem sido colocadas em um mesmo tempo e espaço duas formas distintas de participação social, isto é, um modelo de assembleia, no qual estudantes, professores e servidores estiveram presentes mas não puderam votar, apenas falar e observar, e um modelo de conselho, no qual apenas os conselheiros tinham o poder da deliberação, gerou conflitos profundos com consequências desastrosas. A inabilidade dos gestores do Projeto UNISUS, ou seja, as diretoras e os conselheiros de saúde, em conduzir a reunião através da colocação de duas formas de participação distintas em um mesmo contexto, gerou conflitos e infortúnios severos ao evento deliberativo e ao projeto de transformação institucional em si. Estudantes, professores e servidões da ESCS e da FEPECS estavam presentes, mas sem poder de voto, como se aquele fosse um modelo de assembleia; ao mesmo tempo, os conselheiros de saúde estavam presentes também e eram eles quem tinham o poder da deliberação. O tolhimento oficializado da participação de alguns atores institucionais no mesmo contexto de deliberação sobre um projeto institucional que lhes dizia respeito diretamente, por um lado gerou o colapso de um processo da democracia participativa e de um processo de transformação institucional, e por outro lado, tornou explícitos os posicionamentos dos atores sociais envolvidos, o que é relevante do ponto de vista antropológico.

A falta de articulação prévia e a natureza da composição dos entes representativos da sociedade civil dentro do Conselho de Saúde do Distrito Federal (CSDF), a qual não comporta a representação de movimentos sociais, mas apenas órgãos estruturados que apenas representam indiretamente e apartidariamente determinados grupos civis específicos, implica 
numa negociação frouxa das fronteiras entre a sociedade civil e o Estado nos ambientes de deliberação política. O CSDF, perante a desconfiança generalizada que se estabeleceu entre todos os presentes, encontrou, digamos, um jeito administrativo ao "lavar as mãos" quanto ao Projeto UNISUS, tendo visto que o mesmo já estava previsto nos planos de saúde do governo local. Desse ponto de vista, não houve de fato o silenciamento de um processo democrático ou sua deterioração, pois os posicionamentos dos atores sociais envolvidos foram expressivamente explicitados ao longo do processo narrado, que colocou em evidência a profundidade complexa da disputa de interesses políticos e ideológicos simbolizados pelo Projeto UNISUS naquele contexto específico.

As dificuldades enfrentadas pela forma de participação democrática através do controle social são várias: a primeira gira em torno das limitações do poder de decisão dos conselheiros perante as esferas maiores de poder do controle estatal, ou seja, os resultados idealizados pela democracia participativa representada pelo controle social da saúde são constrangidos pelas relações de poder que se estabelecem dentro da própria máquina pública. A segunda classe de problemas reside na precária organização da atenção à saúde e das demandas sociais que muitas vezes são perpassadas por interesses e. A terceira classe de problemas fica na intensa burocratização das práticas cotidianas dos conselhos fazendo com que boa parte das decisões tomadas sejam definidas pelas Secretaria de Saúde (Shimizu et. al., 2013). A desorganização dos processos imputa problemas à gestão dos projetos públicos e, no tocante à questão dos processos democráticos participativos nas políticas de saúde, existe um grau necessário de organização e regulação da sociedade de acordo com alguns princípios morais que guiam os processos de decisão pública e institucional.

A questão da manutenção da ordem social pode passar a ser determinada por princípios morais que balizaram os mecanismos de cooperação (Douglas, 1986) e aos valores de integração social e democracia que foram vinculados ao controle da sociedade através dos mecanismos do próprio Estado. O poder político, segundo essa ótica, se encontra em uma rede de relações de força que atuam como mecanismos que tanto obrigam quanto habilitam para a ação social ao colocar essas mesmas relações de força e poder no cerne das práticas democráticas e representativas. Entretanto, não se pode reduzir as relações de poder numa oposição binária entre dominados e dominadores, pois as redes de poder são muito mais 
heterogêneas e complexas que convergem em enfrentamentos provisórios intencionais que desafiam a inovação e o movimento de transformação social.

Apesar de a saúde ter sido histórica e politicamente investida no projeto e ideário de nação brasileira desde a consolidação do Sistema Único de Saúde (SUS), a gestão administrativa dos processos políticos da vida cotidiana são repletos de conflitos que existem menos em torno da ideologia resguardada pelos projetos institucionais em si e mais no próprio modo de administração e condução da gestão política cotidiana dos projetos públicos. A fronteira não é entre sociedade civil e Estado como se essas fossem instâncias separadas e definidas claramente. Os mecanismos democráticos não são tão diretos ao ponto de ser possível tal divisão, porque, em certa medida, o Estado é a própria sociedade civil se pensarmos nos mecanismos representativos que administram a vida política cotidiana da gestão da saúde. Entretanto, as intenções dos diversos atores sociais não são providas pelos interesses de um indivíduo apenas ou algum ente coletivo sozinho, mas sim com a sobreposição das intencionalidades exprimidas em momentos específicos de um conjuntura política em torno de um objeto histórico, político, institucional e ideológico que entra em jogo em determinado momento e em determinado espaço. Os enquadramentos sociais se tornam muito complexos.

A desarticulação da representatividade civil dentro dos mecanismos democráticos de participação social previstos pelos mecanismos do Estado, no caso retratado neste trabalho, isto é, o controle social na saúde, parece ser constrangido por rituais cada vez mais burocratizados e insuficientes na efetiva implementação e representação em torno dos projeto públicos voltados para a saúde (Landerdhal et. al., 2010; Shimizu et. al. 2013). Essa forma de organização e funcionamento da democracia participativa através dos Conselhos de Saúde deteriora as discussões e debates mais profundos e preocupados com as necessidades da saúde brasileira o ímpeto rumo à transformações administrativas e sociais mais profundas, cujo tema da reforma e renovação do ensino médico no país tem sido uma das vicissitudes nas arenas intelectuais e políticas brasileiras. Isso configura um processo complexo que diz respeito à administração cotidiana da vida política que lida ao mesmo tempo com uma série de valores morais, visões políticas e projetos ideológicos. Isso ajuda a compreender que o controle social na saúde e os processos deliberativos da democracia participativa são, por natureza, compostos por forças e poderes institucionais que estão além de qualquer interesse individual ou coletivo. 
A renovação do ensino médico no país, seu incremento através de políticas que ampliam $\mathrm{o}$ crescimento de projetos institucionais frente as correntes tradicionais e de ensino $\mathrm{e}$ aprendizagem em medicina que buscam transformar o modelo de gestão de saúde e sua educação com base no rompimento das barreiras institucionais compostas pelas estruturas do próprio Estado se mostrou num campo repleto de disputas e conflitos em torno dos modelos de gestão vigentes no que diz respeito à formação de recursos humanos para a saúde de acordo com as políticas de atenção básica, que veicula uma série de questões que nasceram no âmbito tanto do modelo político democrático de gestão quanto no cotidiano das interações políticas. A conquista de bens coletivos e dos processos de transformações sociais e ideológicas profundas acabam sendo expressas em determinadas formas utópicas de funcionamento e organização dos mecanismos democráticos do Estado. O Estado, entidade imaginada e invisível continua protegido pela sua característica moral de integração e participação cidadã através dos mecanismos de gestão da saúde, entretanto, os processos políticos e administrativos cotidianos são tão frágeis ao ponto de serem dominados por confrontações e trocas de provocações severas diante de um projeto institucional que possuía características transformadoras de uma instituição de ensino em saúde; dos modelos pedagógicos de formação profissional em saúde; da administração do ensino público em saúde; da política de gestão dentro do Estado e; das configurações diversas de valores e ideologias dispostas ao longo desse processo.

É preciso retomar algumas ideias principais levantadas ao longo da dissertação para concluir algumas análises. Apresentei a questão da renovação no ensino em medicina segundo a opinião de diversos atores sociais no primeiro capítulo, chamei a atenção para a centralidade desse tema em algumas arenas de discussão intelectual e política no contexto brasileiro e falei sobre o posicionamento de alguns atores sociais e institucionais em relação à criação da Escola Superior de Ciências da Saúde (ESCS) em Brasília, no Distrito Federal. Enquanto essa era a primeira instituição pública de ensino em medicina do Distrito Federal e adotiva da metodologia pedagógica da Aprendizagem Baseada em Problemas (ABP), diferencial tido pelos interlocutores na pesquisa, ao lado da integração entre ensino e serviço de saúde, como fator essencial para situá-la no campo da "inovação" e "quebra de paradigmas", tanto em relação aos métodos de ensino e aprendizagem quanto aos modelos de gestão em vários aspectos da vida institucional, sua construção era disputada em campos políticos e ideológicos. 
Por ser uma instituição pública gerida pelas instâncias estatais e realizar um parte significativa das atividades pedagógica nas unidades do próprio sistema público de saúde local, daí a mudança no modelo de gestão através do binômio "ensino-serviço", a ESCS desafiava as fronteiras institucionais entre diferentes modelos de gestão política e ideológica de várias formas: uma pela ideia de "integração" ensino-serviço de saúde tanto no nível do processo pedagógico em si quanto no nível da gestão pública da instituição, que desafia a fronteiras políticas entre o ensino da medicina e o serviço público de saúde. No nível pedagógico, o ideário do "médico total", sujeito profissional capaz de ter uma abordagem "bio-psico-social" dos processos de saúde-doença-tratamento, desafia os modelos disciplinares de ensino em medicina e expressam, idealmente, uma alternativa em contraste com o perfil do profissional médico tradicional, fragmentador dos processos "bio-psico-sociais" quando lidam com processos de saúde-doença-tratamento. No nível administrativo, a instituição estudada desafiava os modelos de gestão entre as instâncias públicas de ensino e serviço de saúde, gerando o diálogo entre esses dois campos no que concerne aos elos de interdependência existentes dentro da gestão estatal.

Pra refletir sobre o papel do Estado na gestão da saúde pública, defini o conceito de Estado enquanto uma entidade que não é apenas administrativa, mas também ideológica, e que tem agência centralizadora de determinados ideários nacionais. Para compreender o contexto das políticas de saúde no Brasil, foi necessário fazer uma viagem ao passado histórico quanto ao surgimento do controle do Estado sobre as atividades médicas desde o final do século XIX; passando pela divulgação do Relatório Flexner pela Fundação Rockfeller, nos Estado Unidos, o qual estabeleceu as bases da chamada "medicina das especialidades disciplinares"; até os prelúdios e desenvolvimento do Sistema Único de Saúde (SUS) no Brasil. Discuto como a saúde se tornou mote político e ideológico para a ideia de "nação" e "progresso" no Brasil do início do século XX e como esses lavores foram se atualizando para ideais de "crescimento" e "democracia". No contexto brasileiro, o SUS foi tomado como entidade idealizadora da ideia integração nacional através da saúde através, principalmente, dos princípios de "igualdade", "equidade", universalidade", "participação" e "integralidade", que passaram a significar a consolidação de um país mais democrático através dos serviços de saúde oferecidos pelo próprio Estado. No final do capítulo faço um breve histórico no qual cito políticas públicas voltadas para a educação em saúde no contexto da gestão pública da saúde nacional para 
mostrar como é expressiva a questão da interação entre "saúde" e "educação" em relação à renovação do ensino em medicina no contexto brasileiro.

No segundo capítulo, seguindo a mesma perspectiva histórica do primeiro capítulo, ainda que, no entanto, mais localizada no contexto do Distrito Federal, num primeiro momento, faço uma análise em retrospectiva do histórico de criação da Escola Superior de Ciências da Saúde (ESCS) no Distrito Federal através de uma espécie de "etnografia dos documentos". Através de uma série de documentos institucionais fornecidos pela instituição e outros que pesquisei na internet e outros meios, destaquei a monumentalidade das narrativas institucionais dispostas nos dossiês institucionais e ponderei sobre os valores ideológicos, políticos e administrativos evocados pelos discursos da própria instituição. Voltar ao tempo de criação da ESCS serviu para visualizar quais foram os atores sociais envolvidos no projeto institucional e destacar quais eram os valores ideológicos e morais que foram acionados durante o processo de criação.

Na segunda metade do capítulo faço uma análise etnográfica da metodologia pedagógica adotada pela Escola Superior de Ciências da Saúde (ESCS) e aponto quais os limites de tal metodologia segundo a visão dos próprios interlocutores da pesquisa e teço análises críticas quanto aos desafios administrativos e dilemas que pude perceber ao longo dos processos pedagógicos observados, principalmente aqueles com foco na "atenção básica", tida como uma das políticas de saúde essências ao SUS nos dias atuais. A profundidade dos dilemas internos à metodologia pedagógica adotada pela ESCS - tais como a formação de "médicos totais" com a abordagem integradora "bio-psico-social" com foco na "atenção básica" como fator de orgulho sobreposto à vergonha quanto à falta de pesquisas de ponta e condições infra estruturais - geravam contraste entre um tida maneira "ideal" de se formar, mas dentro de um "real" que é ideologicamente perfeito, porém mal gerenciado prática e politicamente. O final do capítulo mostro quais os desafios e conflitos que existiam na gestão da integração entre "ensino-serviço" na gestão tanto pública quanto pedagógica dos diversos processos que perpassavam a instituição estudada.

O fato que mais chamou a atenção para que eu fizesse uma pesquisa etnográfica da Escola Superior de Ciências da Saúde (ESCS) foi um processo de transformação pelo qual a instituição estava passando no momento que realizei o trabalho de campo, isto é, o processo que visava a transformação da ESCS em Universidade de Ciências da Saúde do Distrito Federal 
(UNISUS). Já no terceiro capítulo, faço a descrição etnográfica de três eventos oficiais que aconteceram na seda da instituição estudada, nos quais o Projeto UNISUS, que visava a transformação da Escola Superior de Ciências da Saúde (ESCS) em Universidade de Ciências da Saúde do Distrito Federal (UNISUS), fora discutido entre diversos atores institucionais envolvidos. Partindo do evento de apresentação do Projeto UNISUS, no qual estudantes, professores e servidores estavam presentes, foi possível perceber os alinhamentos políticos e ideológicos entre os atores institucionais e mapear as demandas e críticas quanto ao processo de transformação que estava acontecendo. Foi interessante notar que os estudantes viram na ocasião de apresentação do Projeto UNISUS uma oportunidade única de reivindicar questões sobre a gestão política e infra estrutural da própria ESCS até aquele momento. Foi uma reunião reveladora dos conflitos internos entre os atores institucionais, fato que fez com que eu mapeasse os posicionamentos dos sujeitos envolvidos em relação aos processos institucionais que aconteciam naquele momento tido pelos sujeitos envolvidos como extraordinário para a história da Escola.

O segundo evento tratou de um debate em torno da minuta do projeto de lei que criava a UNISUS. Qualquer pessoa da sociedade civil poderia ir à essa reunião e sugerir alterações na minuta e debater o projeto da nova universidade. Notou-se que, ao final do debate, a minuta do projeto de lei que criava a UNISUS praticamente não sofreu qualquer alteração significativa em seu conteúdo, mesmo quando algumas reivindicações foram feitas pelos presentes, alterando-se apenas mas apenas alguns termos menores de caráter formal. Isso revelou a complexidade do processo de transformação institucional segundo a perspectiva dos atores institucionais que estavam envolvidos. Nessa reunião foi possível tornar mais claro para mim os posicionamentos dos atores institucionais e perceber melhor os alinhamentos e conflitos internos entre o corpo discente e as diretorias das instituições em relação ao processo de transformação institucional que estava acontecendo.

O último evento foi uma plenária do Conselho de Saúde do Distrito Federal (CSDF) na qual o projeto de lei que fora discutido no debate narrado anteriormente seria deliberado no âmbito do controle social da saúde. Com mais de 300 pessoas dentro do auditório da Fundação de Ensino e Pesquisa em Ciências da Saúde (FEPECS), instituição mantenedora da Escola Superior de Ciências da Saúde (ESCS), estavam presentes: estudantes, professores, servidores, diretores e, obviamente, conselheiros de saúde do Distrito Federal. Aconteceu que, uma 
sequência de erros cometidos pelos anfitriões da plenária durante a reunião, levou ao colapso caótico da plenária em meio a trocas de provocações severas entre os sujeitos presentes. $\mathrm{O}$ fracasso da plenária gerou uma sensação de desconfiança generalizada em relação ao Projeto UNISUS nos dias seguintes quanto à forma pela qual o mesmo estava sendo conduzido nas arenas públicas de discussão e deliberação e quanto às ineficiências da representatividade política do projeto da nova universidade. Em níveis maiores, a celeridade do processo de implantação da nova universidade foi vista como jogada política do então atual governo com vistas à corrida eleitoral no ano seguinte; a má condução da plenária foi vista como fraude de um processo da democracia participativa; a autonomia da ESCS foi questionada perante as instâncias de gestão política e administrativa da instituição. Em níveis menores e micro interativos, o fracasso da plenária em meio à troca de provocações entre aqueles que estavam presentes mostrou a fragilidade das interações sociais, ainda mais quando as trajetórias política e histórica da instituição estavam em jogo e estavam sendo discutidas abertamente. Por ser um mecanismo da democracia participativa que, no entanto é indireto e apartidário, a representatividade da sociedade civil através dos conselheiros de saúde, que respondem por órgãos organizados, mas não por movimentos sociais ou outros agrupamentos sociais, se revelou complexa. Diante da confusão que se estendeu em vários níveis do processo de criação da nova universidade, o Conselho de Saúde do Distrito Federa (CSDF) deu jeito administrativo de passar o projeto de lei adiante através da abstenção eventualmente oficializada em debater o projeto de lei da nova universidade no âmbito do controle social da saúde e passá-lo adiante para outras instâncias executivas do governo local, já que a UNISUS já estava prevista nos planos de saúde do GDF desde 2012. Desde a plenária narrada, o Projeto UNISUS permaneceu no papel e praticamente teve sua tramitação retirada das esferas públicas de discussão no âmbito do controle social e da democracia participativa no que diz respeito à gestão da saúde pública no Distrito Federal. Isso mostrou a complexidade da configuração dos valores dispostos ao longo das reuniões entre os sujeitos institucionais envolvidos com o processo de transformação institucional e revelou como era complexo os processos que a instituição estava passando. Mostrou também os conflitos inerentes ao processo abordado principalmente no que tange à representatividade civil nas instâncias públicas de discussão e deliberação em torno de um projeto público voltado para a saúde, um dos motes das políticas de Estado no Brasil desde a promulgação da Constituição Federal de 1988, da consolidação do Sistema Único de Saúde (SUS) e dos mecanismos de participação social e democrática no âmbito de gestão do Estado. 
Esta dissertação explorou quatro diferentes tipos de profundidade. A primeira delas foi histórica. Para que fosse possível analisar um determinado processo institucional que estava acontecendo no presente, de acordo com os valores que os sujeitos envolvidos traziam e os elementos ideológicos através dos quais o Projeto UNISUS estava sendo discutido em variados contextos, foi necessário fazer um recuo temporal na história da gestão política do Estado sobre as atividades médicas. Com isso foi possível mostrar a profundidade temporal e histórica da questão da renovação do ensino público em saúde para discutir a forma pela qual o controle dos mecanismos de administração do Estado vieram se desenvolvendo ao longo da história. Assim, foi possível perceber os fios conectores da história do Estado com a história de uma instituição pública de ensino em ciências da saúde, e compreender os sentidos dados pelos sujeitos envolvidos aos processos de mudança que estavam acontecendo na instituição nos diferentes níveis da legitimação de seus processos administrativos, políticos e ideológicos.

A segunda foi a profundidade institucional. A partir de um compilado de dossiês com a posterior análise dos discursos evocados por eles, tracei a história de criação da Escola Superior de Ciências da Saúde (ESCS) no Distrito Federal a fim de compreender o momento presente pelo qual a instituição estava passando. Não seria possível compreender o processo de transformação institucional se eu não analisasse a maneira com que a ESCS se posicionava discursivamente a partir de seus documentos oficiais, que evocavam sua monumentalidade no contexto da formação médica local, nacional, quiçá internacional e se não se analisasse o passado histórico da instituição e qual a configuração das relações que a compõem. Foi importante localizar a instituição estudada na rede institucional que ela era localizada para compreender os elos de interdependência que estruturavam e que qualificavam as relações políticas em torno do processo de transformação.

A terceira diz respeito ao tema da pedagogia. Diante do tema da renovação do ensino em medicina, ensaiei uma etnografia em torno da metodologia da Aprendizagem Baseada em Problemas (ABP) cujo foco etnográfico foi no componente curricular da Interação EnsinoServiço-Comunidade (IESC), tido pelos sujeitos envolvidos como essa parte do currículo do curso de medicina da Escola Superior de Ciências da Saúde (ESCS) como a mais "inovadora" por trazer os princípios de "integração" entre ensino e serviço de saúde na atenção básica e também entre os diferentes componentes curriculares que se encontram compartimentados em outros currículos mais tradicionais. A categoria de "médico total", a qual foi a mais citada pelos 
meus interlocutores na pesquisa para definir o profissional que tem abordagem integradora "bio-psico-social" com abordagem socialmente envolvida, evocava a ideia de um novo perfil do profissional médico que traria mudanças mais profundas para o próprio Sistema Único de Saúde (SUS), pois estes, em tese, são melhores conhecedores do funcionamento desse sistema. E vale lembrar que, de fato, tem havido a absorção desses profissionais pelo mercado de trabalho público de medicina, o que significa que, de alguma forma, pelo menos na visão dos sujeitos envolvidos, existe a possibilidade de se mudar o perfil geral dos atendimentos médicos oferecidos pelo SUS. Além disso, acredito que etnografias de processos de aprendizagem em saúde são importantes para que se compreenda melhor quais elementos, processos e relações estão envolvidas em cada tipo de modelo de formação. Estudos nesse sentido estimulam e possibilitam a comparação entre diferentes formas de ensino e aprendizagem e expandem os horizontes etnográficos da antropologia da saúde no que diz respeito ao sentido que cada tipo de prática pedagógica tem no sistema de pensamento daqueles que estão envolvidos com as atividades em cada tipo de curso formativo.

A quarta profundidade explorada diz respeito à política. Percebendo a configuração dos valores que cada ator institucional tinha ao longo dos processos e a forma com que os diferentes posicionamentos puderam ser mapeados, foi possível mapear a própria rede de instituições que estavam relacionadas ao Projeto UNISUS e suas especificidades. Além disso, o tema da "democracia participativa" foi central para que fosse possível compreender como as amarras administrativas públicas estavam relacionadas às idiossincrasias de um projeto institucional na área da saúde. Estabelecer etnograficamente quais foram os posicionamentos de cada ator e grupo institucional nas arenas políticas de discussão e deliberação do Projeto UNISUS me levou a investigar a configuração da política do processo de transformação institucional que estava acontecendo. A gestão desse processo tinha a utilização de mecanismos democráticos para o controle sobre sua trajetória por diversas esferas públicas. Sujeitos investidos em diferentes posições nas instituições e nas arenas políticas dos debates públicos, de acordo com a configuração dos valores expressados na disposição para alinhamentos e conflitos em torno do processo de transformação que estava acontecendo, configuravam um processo histórico, institucional, pedagógico e político complexo e repleto de indicadores do modo como um determinado projeto público de saúde tido como "inovador e paradigmático" foi discutido nas esferas públicas e democráticas em torno de sua criação, implementação e transformação. 
Destaco, finalmente, a contribuição que esta dissertação buscou fazer: propor uma interpretação antropológica do processo abordado a partir de um metodologia de pesquisa que se baseou em: uma etnografia de documentos institucionais, feita através da compilação de uma série de dossiês e permitiu a investigação do problema de pesquisa; uma etnografia dos processos pedagógicos; e uma etnografia do processo de reorganização institucional através da observação de eventos específicos e permitiu o cruzamento dos pontos de vista de diversos atores institucionais envolvidos com os processos que a instituição estudada estava passando. Tanto a análise documental quanto a análise dos processos pedagógicos e dos processos institucionais permitiram abordar o problema de pesquisa nos seus níveis institucionais, pedagógicos, quantitativos, políticos, ideológicos e históricos que compunham a complexidade da questão da renovação do ensino e formação médica no Distrito Federal.

Proponho que as interpretações dos dados construídos nesta dissertação sejam contributivas para a compreensão do sentido do processo de transformação institucional do ensino médico e suas institucionalizações, enquanto expressão do movimento maior que vem acontecendo em nossa sociedade, que é o aumento de uma série de questões às quais o tema da reforma dos modelos de formação médica está intimamente relacionada, principalmente no que diz respeito: às políticas públicas para a saúde; à gestão democrática dos processos públicos institucionais; aos modelos de gestão institucional de instituições de ensino em saúde, principalmente no que tange às relações de interdependência moral e prática com outras instituições que formam redes interinstitucionais complexas; aos modelos de gestão pedagógica e dos processos de ensino aprendizagem através da investigação etnográfica de diferentes alternativas de formação profissional na área da saúde; à gestão política dos processos nas arenas públicas de discussão e deliberação; e à gestão moral e ideológica que é estabelecida ao longo do processo analisado nesta dissertação. 


\section{REFERÊNCIAS BIBLIOGRÁFICAS}

ABRAMS, Philip. [1977] Notes on the Difficulty of Studying the State. Journal of Historical Sociology, v. 1, n. 1, mar, 1988.

ALMEIDA FILHO, Naomar de. [2010] Reconhecer Flexner: inquérito sobre produção de mitos na educação médica no Brasil contemporâneo. Cad. Saúde Pública, Rio de Janeiro, 26(12):2234-2249, dez, 2010.

AZEVEDO, Bruno Mariani de Souza et al. [2013] A formação médica em debate: perspectivas a partir do encontro entre instituição de ensino e rede pública de saúde. Interface (Botucatu), Botucatu, v. 17, n. 44, Mar. 2013.

ANDERSON, Benedict. [1982] Comunidades Imaginadas. São Paulo, Cia das Letras, 2008.

BASEGGIO, Igor D’Ávila. Da Formação de Terapeutas: Uma Etnografia da Prática e do Sentir em uma Escola de Acupuntura. Monografia de Graduação. UnB, 2011.

BATISTA, Karina Barros Calife; GONÇALVES, Otília Simões Janeiro. [2011] Formação dos Profissionais de Saúde para o SUS: Significado e Cuidado. Rev. Saúde e Sociedade v. 20 n. 4 out/dez. pp. 884-899. São Paulo, 2011.

BORBA, Gustavo Severo de; NETO, Francisco José Kliemann. [2008] Gestão Hospitalar: identificação das práticas de aprendizagem existentes em hospitais. Saúde Soc., São Paulo, v. 17, n. 1, Mar. 2008.

BOURDIEU, Pierre. [1967] A Economia das Trocas Linguísticas: O que Falar Quer Dizer. São Paulo: EdUSP, 1996.

[1982] A Economia das Trocas Simbólicas: São Paulo: Perspectiva, 2009. 
BULCÃO, Lúcia Grando; EL-KAREH, Almir Chaiban; SAYD, Jane Dutra. [2007] Ciência e ensino médico no Brasil (1930-1950). Hist. cienc. saúde-Manguinhos, Rio de Janeiro, v. 14, n. 2, jun. 2007.

CASTRO, Celso. [2008] Pesquisando em Arquivos. Rio de Janeiro: Jorge Zahar Ed., 2008.

CYRINO, Eliana Goldfarb; TORALLES-PEREIRA, Maria Lúcia. [2004] Trabalhando com estratégias de ensino-aprendizado por descoberta na área da saúde: a problematização e a aprendizagem baseada em problemas. Cad. Saúde Pública, Rio de Janeiro, v. 20, n. 3, Jun., 2004.

DIAS, Henrique Sant'Anna; LIMA, Luciana Dias de; TEIXEIRA, Márcia. [2013] A trajetória da política nacional de reorientação da formação profissional em saúde no SUS. Ciênc. saúde coletiva, Rio de Janeiro, v. 18, n. 6, June 2013.

DOUGLAS, Mary. [1986] Como as Instituições Pensam. Trad. Carlos Eugênio Marcondes de Moura. São Paulo: EdUSP, 1998.

ELIAS, Norbert. [1939] O Processo Civilizador Volume 2: Formação do Estado e Civilização. Trad. Ruy Jungmann. Rio de Janeiro: Jorge Zahar Ed., 1993.

. [1970] Processos de formação de Estados e construção de nações. In: Nobert Elias. Escritos e Ensaios 1 - Estado, Processo e Opinião Pública, ensaios organizados por Frederico Neiburg e Leopoldo Waizbort. Rio de Janeiro: Jorge Zahar Editor, 2006.

EVANS-PRITCHARD, Edward Evan. [1951] Antropologia Social. Trad. Ana Maria Bessa. Lisboa: Edições 70 Ltda., 2002.

FLEISCHER, Soraya; TORNQUIST, Carmen Susana; MEDEIROS, Bartolomeu Figueiroa. [2010] Popularizando o cuidado com a saúde: Uma apresentação. . Org. Saber

Cuidar, Saber Contar: Ensaios de Antropologia da Saúde Popular. Florianópolis: UDESC, 2010. 
FOUCAULT, Michel. [1963] O Nascimento da Clínica. Org. e Trad. Roberto Machado. Rio de Janeiro: Edições Graal, 2008.

. [1979] Microfísica do Poder. Org. e Trad. Roberto Machado. Rio de Janeiro: Edições Graal, 2008.

GARBI NOVAES, Maria Rita Carvalho et. al. Inserção dos Temas de Humanidades e Ética em Currículo Médico Integrado Em Escola Pública No Distrito Federal, Brasil. Acta bioeth., Santiago, v. 15, n. 2, nov. 2009.

GOFFMAN, Erving. [1963] Comportamento em Lugares Públicos: Notas sobre a Organização Social dos Ajuntamentos. Trad. Fábio Rodrigues Ribeiro da Silva. Petrópolis, Rio de Janeiro: Vozes, 2010.

[1967] Ritual de Interação: Ensaios sobre o Comportamento Face a Face. Trad. Fábio Rodrigues Ribeiro da Silva. Petrópolis, Rio de Janeiro: Vozes, 2012.

[1974] Os Quadros da Experiência Social: Uma Perspectiva de Análise. Trad. Gentil A. Titton. Petrópolis, Rio de Janeiro: Vozes, 2012.

GOMES, Romeu et al. [2009] A formação médica ancorada na aprendizagem baseada em problema: uma avaliação qualitativa. Interface (Botucatu), Botucatu, v. 13, n. 28, Mar. 2009.

GONÇALVES, Davi. [2002] Mudança de paradigma na Educação Médica. Disponível em <http://www.barbier-rd.nom.fr/artDaviPortug.html>. Acessado em abril de 2014.

GONZALEZ, Alberto Durán; ALMEIDA, Marcio José de. Movimentos de mudança na formação em saúde: da medicina comunitária às diretrizes curriculares. [2010] Physis, Rio de Janeiro, v. 20, n. 2, 2010.

GONZE, Gabriela Guerra; SILVA, Girlene Alves da. [2011] A integralidade na formação dos profissionais de saúde: tecendo valores. Physis, Rio de Janeiro, v. 21, n. 1, 2011. 
GUERREIRO, Jória Viana; BRANCO, Maria Alice Fernandes. [2011] Dos pactos políticos à política dos pactos na saúde. Rev. Ciênc. Saúde Coletiva, Rio de Janeiro, v. 16, n. 3, mar., 2011.

HERSCHMANN, Michel; KROPF Simone Petraglia; NUNES, Calrice. [1996] Missionários do Progresso: Médicos, Engenheiros e Educadores no Rio de Janeiro 1870 - 1937. Copacabana, Rio de Janeiro: Diadorim Editora Ltda., 1996.

HORA, Dinair Leal da et al. [2013] Propostas inovadoras na formação do profissional para o Sistema Único de Saúde. Trab. educ. saúde, Rio de Janeiro, v. 11, n. 3, Dec. 2013.

LANDERDHAL, Maria Celeste et. al. [2010] Resoluções do Conselho de Saúde: Instrumentos de controle social ou documento burocrático? Rev. Ciênc. Saúde Coletiva, Rio de Janeiro, v. 15, n. 5, ago. 2010.

LIMA, Nísia Trindade ; HOCHMAN, Gilberto. [2000] Pouca saúde, muita saúva, os males do Brasil são... Discurso médico-sanitário e interpretação do país. Rev. Ciênc. Saúde Coletiva, vol.5, n.2, pp. 313-332, 2000.

MACHADO, Roberto et. al. [1978] Danação da Norma: A Medicina Social e a Constituição da Psiquiatria no Brasil. Rio de Janeiro: Edições Graal, 1978.

MATTA, Roberto da. [1978] Carnavais, Malandros e Heróis: Para uma Sociologia do Dilema Brasileiro. Rio de Janeiro: Jorge Zahar Ed., 1981.

NOGUEIRA, Carolina. [2001] Faculdade Rejeitada. Correio Brasiliense, Brasília, pág. 9, 06, mar., 2001.

PAGLIOSA, Luiz Fernando; ROS, Marco Aurélio Da. [2008] O Relatório Flexner: Para o Bem e para o Mal. Rev. Brasileira de Educação Médica 32 (4): 492-499, 2008.

PALMEIRA, Moacir. [2002] O dito e o Feito: ensaios de antropologia dos rituais. Org. Mariza Peirano. Rio de Janeiro: Relume Dumará: Núcleo de Antropologia da Política, UFRJ, 2002. 
PEREIRA, Ondina Pena; ALMEIDA, Tãnia Mara Campos de. [2005] A formação médica segundo uma pedagogia de resistência. Interface (Botucatu), Botucatu, v. 9, n. 16, Feb. 2005 .

SHIMIZU, Helena Eri et. al. [2013] Representações Sociais dos Conselheiros Municipais Acerca do Controle Social no SUS. Rev. Ciênc. Saúde Coletiva, Rio de Janeiro, v. 18, n. 8, ago., 2013.

SIQUEIRA-BATISTA, Rodrigo et al . [2013] Educação e competências para o SUS: é possível pensar alternativas à(s) lógica(s) do capitalismo tardio?. [2013] Ciênc. saúde coletiva, Rio de Janeiro, v. 18, n. 1, Jan. 2013.

SIQUEIRA-BATISTA, Rodrigo; SIQUEIRA-BATISTA, Romulo. [2009] Os Anéis da Serpente: a Aprendizagem Baseada em Problemas e as Sociedades de Controle. Rev. Ciência e Saúde Coletiva, Rio de Janeiro, v. 14, n. 4, agosto, 2009.

SOUZA, Alicia Navarro. [2001] Formação Médica, Racionalidade e Experiência. Ciência e Saúde Coletiva, 6 (1):87-96, 2001.

SPOSATI, Aldaíza; LOBO, Elza. [1992] Controle Social e Políticas de Saúde. Cad. Saúde Pública, v. 8, n. 4. Dez, 1992.

SWAAN, Abram de. [1988] In Care of the State: Health Care, Education and Welfare in Europe and the USA in the Modern Era. New York: Oxford University Press, 1988.

TEIXEIRA, Carla Costa, SIMAS, Diego da Hora e COSTA, Nilton Miguel Aguiar. [2013] Controle Social na Saúde Indígena: limites e possibilidades da democracia direta. Tempus - Actas de Saúde Coletiva v. 7 n. 4, 2013.

VILELA, Elaine Morelato; MENDES, Iranilde José Messias. [2003] Interdisciplinaridade e Saúde: Estudo Bibliográfico. Rev. Latino-americana de Enfermagem. São Paulo, 11(4):525-531, jul/ago, 2003. 


\section{REFERÊNCIAS DOCUMENTAIS}

BRASIL. Conselho Nacional de Saúde. [2006] SUS: avanços e desafios. Conselho Nacional de Saúde. Brasília: CONASS, 2006.

[1988] Presidência da República. Constituição da República Federativa do Brasil de 1988.

[1990] Presidência da República. Lei No 8.080, de 18 de setembro de 1990.

CAPITANI, Gislene e TEODORO, Maria Dilma. [2013] Projeto UNISUS: Onde Estamos? Para Onde Vamos? Apresentação de slides em PDF. Disponível em: <http://www.fepecs.edu.br/index.php/noticias/390-apresentacao-do-processo-daunisus-e-disponibilizado-no-site-da-fepecs> Consultado em: 21/08/2013.

CONSELHO DE EDUCAÇÃO DO DISTRITO FEDERAL. [2001] Parecer No 95/2001CEDF.

CORREIO BRASILIENSE. [2001] Faculdade rejeitada. NOGUEIRA, Carolina. Cidades, p. 9. Brasília, 6 de março de 2001.

CONSELHO DE SAÚDE DO DISTRITO FEDERAL. [2001] Regimento Interno do Conselho de Saúde do Distrito Federal. Resolução no 32 de 22 nov. de 2011 In. DODF Ano XLIII No 236, Brasília, segunda-feira, 12 de dezembro de 2011.

ESCOLA SUPERIOR DE CIÊNCIAS DA SAÚDE. [2001] Projeto Político-Pedagógico. Brasília: ESCS, 2001.

[2012] Manual do Estudante. Brasília: ESCS, 2012. 
. [2012] Regimento da Escola Superior de Ciências da Saúde. Brasília: ESCS, 2012.

ESCOLA TÉCNICA DE SAÚDE DE BRASÍLIA. [2011] Histórico. Disponível em: <http://www.etesb.fepecs.edu.br> Consultado em: 06/05/2014.

FUNDAÇÃO DE ENSINO E PESQUISA EM CIÊNCIAS DA SAÚDE. [2002] Criação da Fundação de Ensino e Pesquisa em Ciências da Saúde e do Curso de Medicina da Secretaria de Estado de Saúde do Distrito Federal: Dossiê. Brasília: FEPECS, 2002.

. [2013] Histórico. Disponível em: <http://www.fepecs.edu.br/index.php/ institucionalgeral> Consulado em: 11/04/2014.

[2013] Ata da 97 Reunião Ordinária do Conselho Deliberativo. Brasília: FEPECS, 2013.

[2013] Minuta: Altera a Lei de Criação da Fundação de Ensino e Pesquisa em Ciências da Saúde e dá outras providências. Brasília: FEPECS, 2013.

Diretoria Executiva. [2013] O Porquê da Universidade de Ciências da Saúde no Distrito Federal: Documento-síntese. Brasília: FEPECS: Nov. 2013.

GOVERNO DO DISTRITO FEDERAL. [2001] Lei Nº 2.676, de 12 de janeiro de 2001.

SECRETARIA DE ESTADO DE SAÚDE DO DISTRITO FEDERAL - Saúde em Ação: Boletim Informativo da Secretaria de Saúde do Distrito Federal, Ano I nº 9, Setembro de 2000.

. [2000] Portaria No 6, de 02 de agosto de 2000.

. [2012] Plano Distrital de Saúde 2012 à 2015. Governo do Distrito Federal. Brasília, Junho de 2013. 


\section{ANEXO}

Ficha A de Cadastro da Família. Programa Família Saudável. GDF.

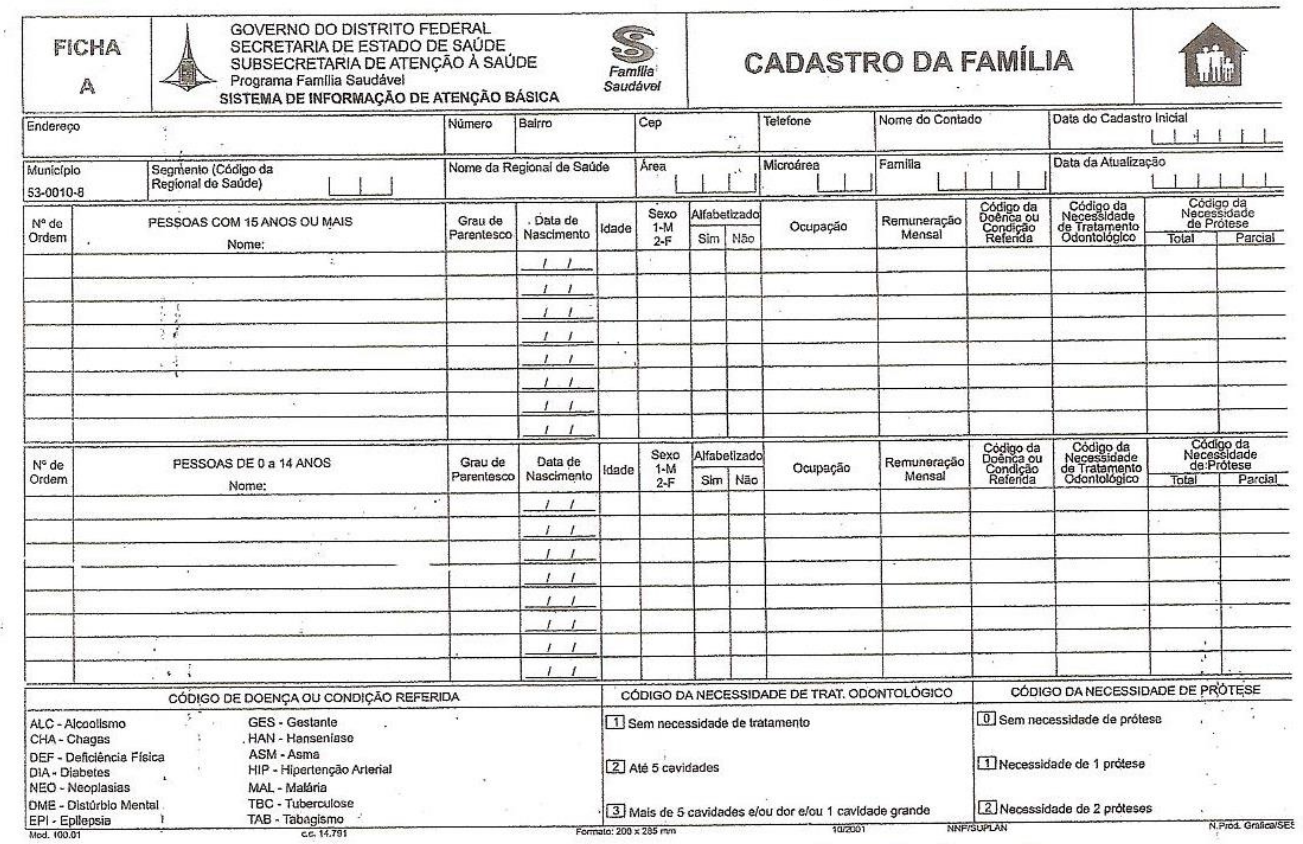

SITUACÄO DAMORADIAE SANEAMENTO

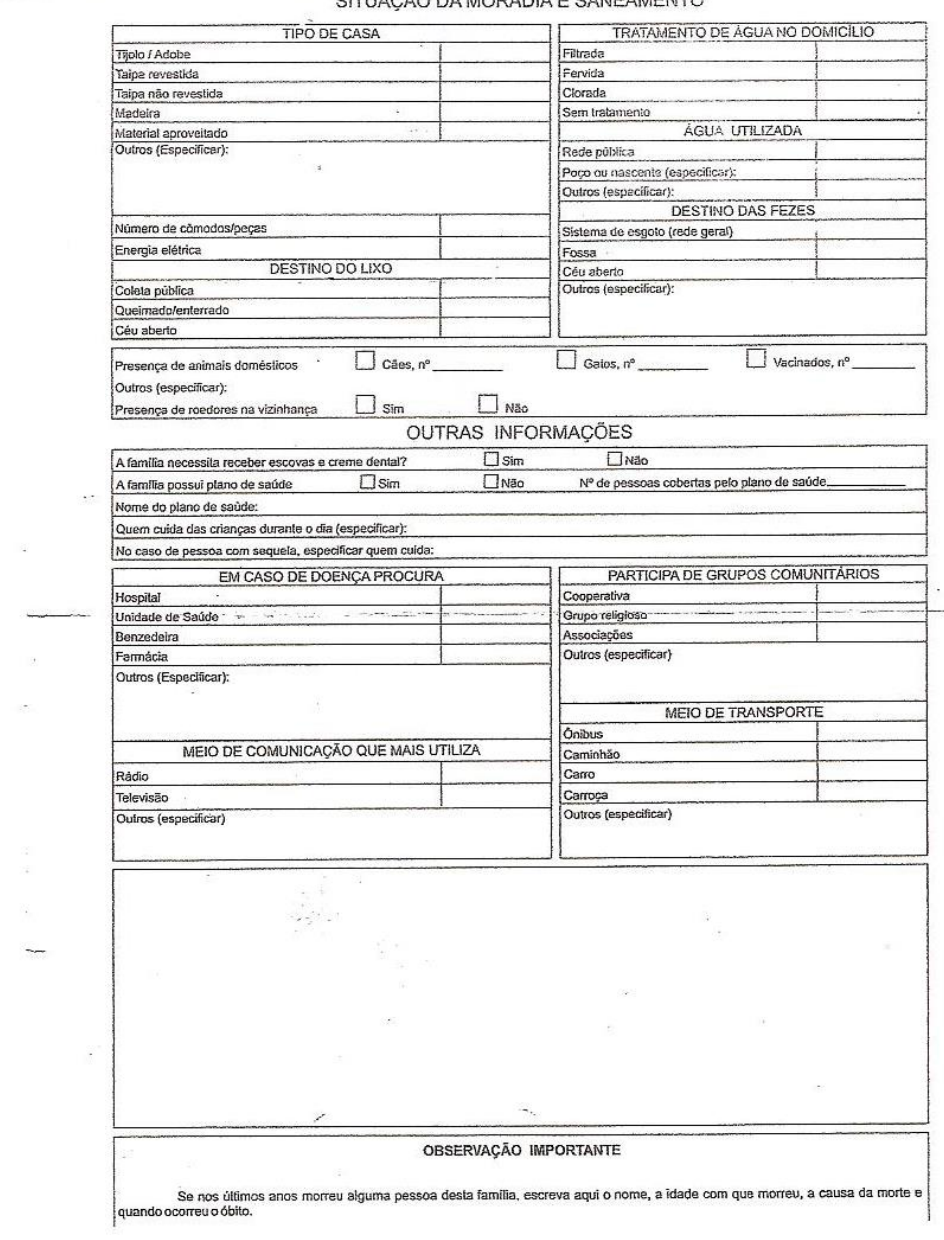




\section{APÊNDICE}

Tabela de distribuição anual das admissões feitas pela a de Estado de Saúde do Distrito Federal - SES-DF de médicos egressos da Escola Superior de Ciências da Saúde (ESCS). Relação: ano de formação-ano de admissão.

\begin{tabular}{|c|c|c|c|c|c|c|c|c|c|}
\hline 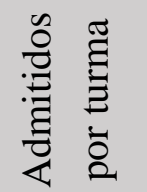 & ते & d & $\stackrel{\mathbb{N}}{ }$ & ి & $\stackrel{\circ}{+}$ & ले & $\stackrel{\mathscr{F}}{+}$ & $\underset{m}{\infty}$ & రి \\
\hline$\stackrel{\vec{d}}{\stackrel{d}{\sigma}}$ & 0 & $m$ & 0 & 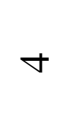 & $\sim$ & $N$ & $\nabla$ & $\hat{\lambda}$ & F \\
\hline$\stackrel{m}{\vec{N}}$ & $\infty$ & $\infty$ & $m$ & $r$ & $\mathscr{\Omega}$ & $\simeq$ & ले & $=$ & $\underset{\Xi}{ \pm}$ \\
\hline$\stackrel{\sim}{\stackrel{\sim}{े}}$ & $N$ & $\nabla$ & $r$ & $N$ & $\simeq$ & $\curvearrowright$ & 0 & 1 & f \\
\hline$\overline{\vec{\partial}}$ & in & $\infty$ & $m$ & $n$ & $\simeq$ & $m$ & 1 & 1 & i \\
\hline$\stackrel{\circ}{\stackrel{\sim}{\sim}}$ & $r$ & $\nabla$ & $\infty$ & $\sim$ & - & I & I & 1 & ส \\
\hline ठ্ेે & in & $N$ & $N$ & 0 & 1 & 1 & 1 & 1 & $a$ \\
\hline 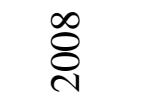 & $N$ & - & - & 1 & 1 & 1 & 1 & 1 & $\nabla$ \\
\hline 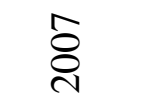 & 0 & 0 & 1 & 1 & 1 & 1 & 1 & 1 & 0 \\
\hline 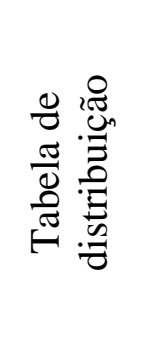 & 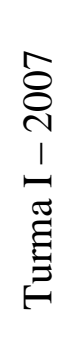 & 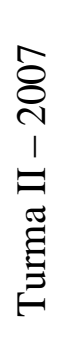 & 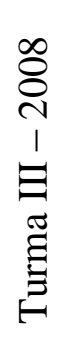 & 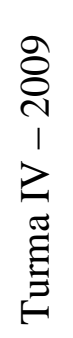 & 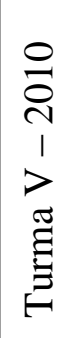 & 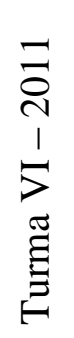 & 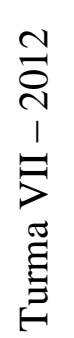 & 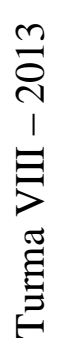 & 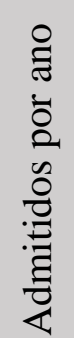 \\
\hline
\end{tabular}

